$$
\text { UNIVERSIDADE DE SÃO PAULO }
$$

FACULDADE DE FILOSOFIA, CIÊNCIAS E LETRAS DE RIBEIRÃO PRETO PROGRAMA DE PÓS-GRADUAÇÃO EM EDUCAÇÃO

\title{
AVALIAÇÃO DIALÉTICA: da medição à mediação
}

\author{
ANA CAROLINA DE FAZZIO CARMO PRADO
}

Dissertação apresentada ao programa de PósGraduação em Educação da Faculdade de Filosofia, Ciências e Letras de Ribeirão Preto da Universidade de São Paulo para obtenção do título de Mestra em Ciências. Área de Concentração: Educação

RIBEIRÃO PRETO - SP 2021 



\section{AVALIAÇÃo DIALÉTICA: da medição à mediação}

Dissertação apresentada ao programa de Pós-Graduação em Educação da Faculdade de Filosofia, Ciências e Letras de Ribeirão Preto da Universidade de São Paulo para obtenção do título de Mestra em Ciências.

Área de Concentração: Educação

Orientadora: Prof. ${ }^{a}$ Dr. ${ }^{a}$ Elaine Sampaio Araujo 
Autorizo a reprodução e divulgação total ou parcial deste trabalho, por qualquer meio convencional ou eletrônico, para fins de estudo e pesquisa, desde que citada a fonte.

Prado, Ana Carolina de Fazzio Carmo

AVALIAÇÃO DIALÉTICA: da medição à mediação. Ribeirão Preto, 2021

180 p. : il. ; $30 \mathrm{~cm}$

Dissertação de Mestrado, apresentada à Faculdade de Filosofia, Ciências e Letras de Ribeirão Preto/ USP. Área de concentração: Educação.

Orientador: Araujo, Elaine Sampaio

1. Avaliação. 2. Avaliação Dialética. 3. Zona de Desenvolvimento Proximal. 4. Habilidades. 5. Atividade Orientadora de Ensino. 
PRADO, A. C. F. C. Avaliação Dialética: da medição à mediação. Ribeirão Preto, 2021. 170 p. Dissertação (Mestrado) - Faculdade de Filosofia, Ciências e Letras de Ribeirão Preto, Universidade de São Paulo, Ribeirão Preto, 2021.

Aprovada em:

\section{Banca Examinadora}

Professora Dr. ${ }^{\text {a }}$ Elaine Sampaio Araujo

Instituição: Universidade de São Paulo

Julgamento:

Assinatura:

Professora Dr. ${ }^{\text {a }}$ Cristina Cinto Araújo Pedroso

Instituição: Universidade de São Paulo

Julgamento:

Assinatura:

Professora Dr. ํㅗㄴ Silvia Pereira Gonzaga de Moraes

Instituição: Universidade Estadual de Maringá

Julgamento:

Assinatura:

Professora Dr. ․ㅡ Andréa Maturano Longarezi

Instituição: Universidade Federal de Uberlândia

Julgamento:

Assinatura: 
Ao meu filho e meu marido, Gabriel e Daniel; Aos meus pais, Elaine e Luiz; Ao meu irmão Diego; Á todos que me chamaram e me chamarão de "tia". 


\section{AGRADECIMENTOS}

Agradeço a Deus pelo sustento e fortalecimento diário. Muitos foram os momentos de oração e em dobro foram as bênçãos.

Agradeço ao meu filho amado, Gabriel, por me acalmar com seu olhar, seu sorriso e seus abraços. Sua chegada trouxe nova cor ao meu dia, nova esperança em meu coração e novas possibilidades a minha vida.

Ao meu marido, Daniel, por caminhar comigo ao longo deste processo de desenvolvimento, pois sua paciência sem tamanho e prontidão em me ajudar, fizeram e fazem a "corrida" da vida ser mais leve.

Aos meus pais, Elaine e Luiz, por acreditarem e me fazerem acreditar que eu conseguiria. Sem o amor incondicional, o auxílio diário e o socorro imediato que sempre me deram, nada teria sido possível da forma que foi.

Agradeço ao meu irmão, Diego, pelas conversas sobre planos para a vida e por fazer parte de cada um deles.

À minha querida orientadora, professora Elaine, pois sua alegria contagiante me ensinou muito mais que conceitos. Construímos vivências recheadas de sentidos que, por mim, jamais serão apagados.

Agradeço a todos os grupos, pela ajuda na construção das bases teóricas que alicerçaram essa pesquisa e que se estenderam para vida. Em especial, agradeço ao GEPEAMI, grupo que fui recebida com abraços apertados, que me ajudaram a secar algumas lágrimas e me revigoravam a cada encontro.

Agradeço aos docentes da Faculdade de Filosofia, Ciências e Letras de Ribeirão Preto (FFCLRP/USP), que contribuíram com minha formação na PósGraduação (PPGEdu-FFCLRP/USP) e a todos que estiveram comigo ao longo da graduação, do magistério e do ensino fundamental, cada um, de modo legítimo, possibilitaram condições para que, mais do que direito a aprendizagem, eu tivesse acesso ao direito a educação.

Enfim, agradeço a todos que me ajudaram nesta longa jornada. Apesar de árdua, ela sempre me proporcionou incontáveis alegrias. 
"Digo-Ihes hoje, meus amigos, que, apesar das dificuldades e frustrações do momento, eu ainda tenho um sonho."

Martin Luther King 
PRADO, A. C. F. C. Avaliação Dialética: da medição à mediação. Ribeirão Preto, 2021. 180 p. Dissertação (Mestrado) - Faculdade de Filosofia, Ciências e Letras de Ribeirão Preto, Universidade de São Paulo, Ribeirão Preto, 2021.

\section{RESUMO}

Esta pesquisa parte da compreensão da avaliação como componente intrínseco ao movimento de ensino e de aprendizagem na perspectiva histórico-cultural. Busca compreender e explicitar a significação e a vivência da avaliação como unidade mediadora no processo em que o objeto do conhecimento humano, construído historicamente, revela-se às gerações posteriores por meio dos objetos de ensino. Indica-se como as necessidades subjacentes ao uso da avaliação e os motivos que a sustentam para verificação dos conhecimentos a têm configurado como modelador da prática docente, determinando, muitas vezes, o currículo e os objetivos da atividade pedagógica. Na busca de uma conceitualização, procura-se deslocá-la de seu lugar de medidora, para ocupar um novo espaço - de mediadora - e possibilitar aos sujeitos, em atividade de ensino e em atividade de aprendizagem, compreendê-la como possibilidade de análise e síntese da relação ensino-aprendizagem, com vistas à formação do pensamento teórico. A lógica do trabalho alicerça-se em quatro movimentos interdependentes: dos Princípios, das Propostas, das Práticas e das Possibilidades. Nos Princípios, discutem-se os papéis sociais ocupados pela criança e pelo adulto que, na relação professor-estudante, constituem-se por concepções de aprendizagem e desenvolvimento. Procura-se vincular a avaliação como possibilidade de desenvolvimento prospectivo e os princípios presentes no conceito de Zona de Desenvolvimento Proximal, desenvolvido por Vigotski e seus colaboradores. Nas Propostas, considera-se a Base Nacional Comum Curricular para discutir sua relação mandatária com a organização do currículo, e sobretudo, sua influência na orientação de práticas e condutas dos sujeitos da escola. Lançando mão da comum associação entre avaliação e instrumentos utilizados para avaliar, nas Práticas tece-se uma análise sobre as dimensões implícitas nos instrumentos físicos, bem como na pseudointencionalidade pedagógica que os sustenta, buscando compreender a avaliação em sua dimensão dialética, que se objetiva na atividade pedagógica. Aos sujeitos em atividade de ensino e aos sujeitos em atividade de aprendizagem, possibilitam-se condições para apropriar-se dos nexos próprios da formação do pensamento teórico. Aborda-se também a avaliação dialética no ensino remoto, modalidade educativa que se instalou como medida protetiva diante da pandemia causada pela Covid-19. Nas Possibilidades, parte-se de uma situação comum a muitas vivências em espaços escolares, para expor como a Avaliação Dialética se constitui como possibilidade de passagem da qualidade subjacente aos instrumentos operacionalizados nas salas de aula, de medidora da aprendizagem, para a função de ação-instrumento mediador entre o ensino e a aprendizagem. Apresenta-se a relação entre os princípios da Avaliação Dialética, vinculando-os aos preceitos teórico-metodológicos presentes na Atividade Orientadora de Ensino, que centraliza o planejamento, a realização e o desfecho de uma situação de aprendizagem, em que a Avaliação Dialética se constitui como unidade na totalidade da atividade docente. Por fim, 
apresenta-se uma história virtual em que a avaliação dialética se constitui como exemplo de tomada de consciência sobre todas as etapas da atividade de ensino.

Palavras-chave: Avaliação. Avaliação Dialética. Zona de Desenvolvimento Proximal. BNCC. Habilidades. Atividade Orientadora de Ensino 
PRADO, A. C. F. C. Dialectical Assessment: from the measure to the mediation. Ribeirão Preto, 2021. 180 p. Dissertation (Masters) - Faculdade de Filosofia, Ciências e Letras de Ribeirão Preto, Universidade de São Paulo, Ribeirão Preto, 2021.

\section{ABSTRACT}

This research is based on the understanding of assessment as an intrinsic component of the teaching and learning movement from a cultural-historical perspective. It seeks to understand and explain the meaning and experience of assessment as a mediating unit in the process in which the object of human knowledge, historically constructed, reveals itself to later generations through teaching objects. It indicates how the needs underlying the use of assessment and the reasons that support it to verify knowledge have configured it as a modeler of the teaching practice, often determining the curriculum and the objectives of the pedagogical activity. In the search for a conceptualization, we seek to displace it from its place of measurer, to occupy a new place - of mediator - and enable subjects, in teaching and learning activities, to understand it as a possibility of analysis and synthesis of the teaching-learning relationship, with a view to the formation of theoretical thinking. The logic of the work is based on four interdependent movements: Principles, Proposals, Practices and Possibilities. The Principles discuss the social roles occupied by the child and the adult who, in the teacher-student relationship, are constituted by concepts of learning and development. It seeks to link the evaluation as a possibility of prospective development and the principles present in the concept of Proximal Development Zone, developed by Vigotski and his collaborators. In the Proposals, the Common National Curriculum Base is considered to discuss its mandatory relationship with the organization of the curriculum, and above all, its influence on the orientation of practices and behaviors of the subjects of the school. Making use of the common association between assessment and instruments used to evaluate, in Practices an analysis of the dimensions implicit in physical instruments, as well as the pedagogical pseudo-intentionality that support them, are carried out, seeking to understand assessment in its dialectical dimension, which is aimed at the teaching activity. Subjects in teaching activities and subjects in learning activities are provided with conditions to appropriate the nexus of theoretical thought formation. It also addresses dialectical assessment in remote education, an educational modality that was installed as a protective measure in the face of the pandemic caused by Covid-19. In Possibilities, we start from a situation common to many experiences in schools, to expose how Dialectical Assessment is constituted as a possibility of passing the quality underlying the instruments operated in the classroom, from measuring learning to the function of actionmediator instrument between teaching and learning. The relationship between the principles of Dialectic Evaluation is presented, linking them to the theoretical- 
methodological precepts present in the Teaching Guidance Activity, which centralizes the planning, realization and conclusion of a learning situation, in which Dialectic Evaluation constitutes. as a unit in the totality of the teaching activity. Finally, a virtual history is presented in which the dialectical assessment is an example of the awareness of all stages of the teaching activity.

Keywords: Evaluation. Dialectical Evaluation. Proximal Development Zone. BNCC. Skills. Guiding Teaching Activity 


\section{LISTA DE FIGURAS}

FIGURA 1. Representação da analogia entre o desenho infantil de uma linha em espiral e o movimento entre os níveis de desenvolvimento. .40

FIGURA 2. Movimento dialético e prospectivo de desenvolvimento, baseado no conceito de Zona de Desenvolvimento (VIGOSTSKI, 2001).

FIGURA 3. Síntese da relação entre os elementos que compõem a organização do ensino.

.63

FIGURA 4. Informações complementares para leitura do código alfanumérico..73 


\section{LISTA DE QUADROS}

QUADRO 1. Lógica de exposição da pesquisa .23

QUADRO 2. Habilidades a serem desenvolvidas do $1 .{ }^{\circ}$ ao $5 .^{\circ}$ ano do E.F .72

QUADRO 3. Habilidades referentes ao ensino de horas no E.F. .75

QUADRO 4. Síntese da análise de uma sequência didática para o ensino de medidas de tempo a partir dos princípios da escola tradicional analisados por Davidov (2017) .80

QUADRO 5. Comparativo entre Avaliações Somativas do $1 .^{\circ}$ ao $5 .^{\circ}$ ano do E. F. (2016) 106 


\section{LISTA DE GRÁFICOS}

GRÁFICO 1. Percentual de analfabetos no período entre 2001 e $2018 \ldots \ldots \ldots \ldots . . . .48$ 


\section{LISTA DE SIGLAS E ABREVIATURAS}

$\begin{array}{ll}\text { AAP } & \text { Avaliação da Aprendizagem em Processo } \\ \text { AD } & \text { Avaliação Dialética } \\ \text { ANA } & \text { Avaliação Nacional de Alfabetização } \\ \text { AOE } & \text { Atividade Orientadora de Ensino } \\ \text { BNCC } & \text { Base Nacional Comum Curricular } \\ \text { DCN } & \text { Diretrizes Curriculares Nacionais } \\ \text { EF } & \text { Ensino Fundamental } \\ \text { ENEM } & \text { Exame Nacional do Ensino Médio } \\ \text { GEPEAMI } & \text { Grupo de Estudos e Pesquisa do Ensino e Aprendizagem da } \\ & \text { Matemática na Infância } \\ \text { GTP } & \text { Grupo de Trabalho Pedagógico } \\ \text { IDEB } & \text { Índice de Desenvolvimento da Educação Básica } \\ \text { IDESP } & \text { Índice de Desenvolvimento da Educação do Estado de São } \\ & \text { Paulo } \\ \text { MEC } & \text { Ministério da Educação } \\ \text { NP } & \text { Núcleo Pedagógico } \\ \text { OPM } & \text { Oficina Pedagógica Matemática } \\ \text { PDE } & \text { Plano de Desenvolvimento da Educação } \\ \text { PCN } & \text { Parâmetros Curriculares Nacionais } \\ \text { RIBDOWN } & \text { Associação Síndrome de Down Ribeirão Preto } \\ \text { SAEB } & \text { Sistema de Avaliação da Educação Básica } \\ \text { SARESP } & \text { Sistema de Avaliação do Rendimento Escolar do Estado de } \\ \text { SME } & \text { São Paulo } \\ & \text { Secretaria Municipal de Educação }\end{array}$




\section{SUMÁRIO}

O PERCURSO

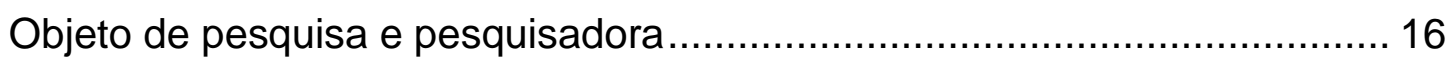

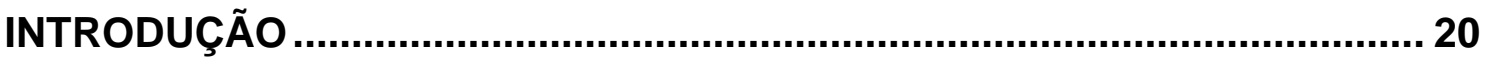

1. SOBRE OS SUJEITOS QUE VIVEM A AVALIAÇÃO E AS RELAÇÕES QUE CONSTITUEM AS POSSIBILIDADES DE DESENVOLVIMENTO

HUMANO

1.1. Da relação entre a criança e o adulto................................................ 31

1.2. Da relação entre as concepções de aprendizagem e de

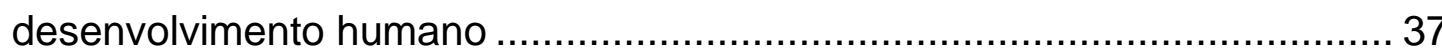

1.3. Da relação entre o desenvolvimento humano e a avaliação ............... 47

2. UM OLHAR PARA A BNCC E SUA RELAÇÃO COM O CURRÍCULO, AS PRÁTICAS E AS CONDUTAS ESCOLARES

2.1. Para além da declaração: do direito a aprendizagem à luta pela universalização do ensino ......................................................................... 54

2.2. A relação entre os elementos que compõem o ensino.......................... 61

2.3. Do levantamento de conhecimentos prévios à avaliação da aprendizagem: análise dos princípios de "uma boa situação de aprendizagem"

3. ALGUMAS DIMENSÕES DA AVALIAÇÃO: DA PSEUDOINTENCIONALIDADE PEDAGÓGICA À FORMAÇÃO DA CONSCIÊNCIA DOCENTE

3.1. A dimensão instrumental da avaliação …………............................. 94

3.2. A dimensão operacional da avaliação............................................. 103

3.3. Análise de instrumentos comumente operacionalizados para

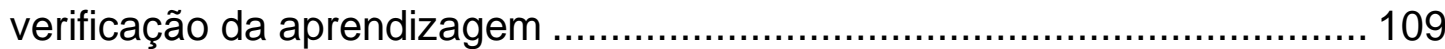

3.4. A dimensão dialética da avaliação ................................................ 118

3.5. A avaliação dialética no ensino (remoto, o inesperado) .................... 125

4. A AVALIAÇÃO DIALÉTICA: DA MEDIÇÃO À MEDIAÇÃO.....................137

4.1. A relação entre a Avaliação Dialética e a Atividade Orientadora de

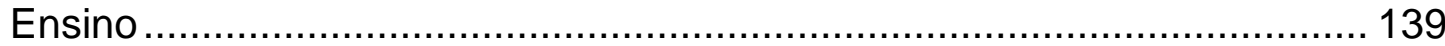

4.2. A Avaliação Dialética na atividade de ensino .................................. 147

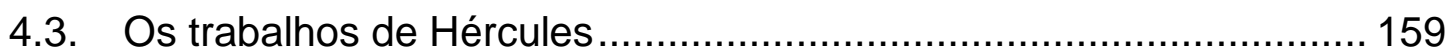

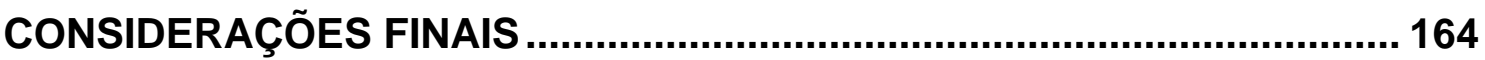

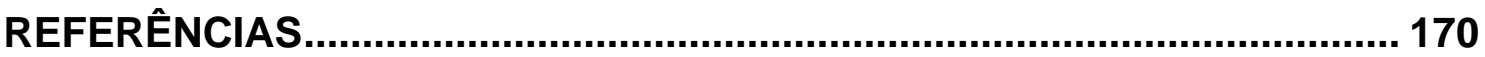

ANEXOS 


\section{O PERCURSO}

Objeto de pesquisa e pesquisadora

Comumente, observamos que a defesa da ideia da escola como um espaço democrático decorre de alguns princípios, cujos alicerces estão fincados no direito de aprendizagem, previsto em lei a partir da Constituição de 1988, cujo artigo 205 define que

a educação, direito de todos e dever do Estado e da família, será promovida e incentivada com a colaboração da sociedade, visando ao pleno desenvolvimento da pessoa, seu preparo para o exercício da cidadania e sua qualificação para o trabalho. (BRASIL, 1988, art. 205)

Com efeito, ao longo dos anos subsequentes, a escola e seus principais sujeitos, professor e estudante, puderam vivenciar a implementação de diferentes políticas que, voltadas à melhoria da qualidade da educação, buscavam importar do cenário econômico práticas e condutas capazes de alavancar a educação nacional. Todavia, o que "sentimos na pele" - a incessante análise de "índices" e a incansável busca por "bonificações" - pode, muitas vezes, ser comparado à pressão pelo cumprimento de "metas" que, não necessariamente, carregam em si possibilidades para o desenvolvimento dos sujeitos.

Nessa relação, as práticas avaliativas, sobretudo a "avaliação da aprendizagem", consolidaram-se como instrumentos preponderantes no ensino, cujo objetivo central liga sua operacionalização à necessidade de obter resultados que, por sua vez, assumem o papel de orientadores dos objetivos e dos conteúdos escolares, influenciam o desenvolvimento da atividade docente e fazem com que os professores recorram a formas que pouco ou nada contribuem para o desenvolvimento dos estudantes, mas, de uma maneira ou de outra, garantem os resultados esperados (FREITAS, 2014).

Em 2014, esse espaço era o lugar em que me encontrava. Imersa em um emaranhado de dúvidas, sentindo urgência em buscar respostas que explicassem os "porquês de," eu não conseguir fazer com que todos os 
estudantes da turma "aprendessem o que eu estava ensinando", por mais que me esforçasse para alcançar tais resultados.

Em resposta às minhas investidas, colegas buscavam me consolar, dizendo que esse "problema era algo normal do sistema educacional", pois a aprendizagem de muitas crianças está condicionada a requisitos como estrutura familiar, condições de moradia e alimentação, infraestrutura das escolas, acesso a tratamentos psicológicos, fonoaudiológicos e neurais, entre tantos outros...

Fora do ambiente de trabalho, passei a participar dos encontros organizados pela Associação Síndrome de Down Ribeirão Preto - Ribdown -, em que o grupo de professores tinha como objetivo estudar os princípios e as estratégias do Projeto Roma, que discute a educação inclusiva, e divulgar conhecimentos produzidos a partir de estratégias experienciadas em sala de aula.

Nesses estudos e discussões em grupo, a primeira "resposta" para as minhas dúvidas foi a de que, para construirmos uma "educação inclusiva", não poderíamos voltar nosso olhar apenas à pessoa com deficiência, pois a sala de aula, como um espaço coletivo de confiança, aprendizagem e desenvolvimento, deveria ser inclusiva para todos, e não apenas para o estudante com deficiência (MELERO, 1999).

Desse modo, mais do que nunca, a necessidade de buscar meios que pudessem, sobretudo, possibilitar aos estudantes condições para apropriar-se dos conteúdos que eu ensinava e, com isso, ter bons resultados nas avaliações, motivava-me a continuar buscando respostas.

Então, em 2016, escrevi meu primeiro projeto para ingresso no mestrado, com objetivo de pesquisar os "porquês" da defasagem dos estudantes dos anos iniciais do ensino fundamental, principalmente na área de Matemática, pois, de acordo com os resultados do SARESP ${ }^{1}$ do ano anterior, na escola na qual lecionava, tanto no terceiro como no quinto ano, havia, em relação à Diretoria de Ensino, Interior e Rede Estadual como um todo, aproximadamente dez pontos

\footnotetext{
${ }^{1}$ Sistema de Avaliação do Rendimento Escolar do Estado de São Paulo - avaliação externa, aplicada anualmente, desde 1996, pela Secretaria da Educação do Estado de São Paulo (SEE/SP) para avaliar sistematicamente o Ensino Básico na rede estadual e produzir um diagnóstico do rendimento escolar básico paulista.
} 
percentuais a mais de estudantes no nível insuficiente nesta área do conhecimento (BRASIL, 2015).

Naquele ano não ingressei no mestrado, mas, em contato com a Prof. ${ }^{\text {a }}$ Dr. ${ }^{\text {a }}$ Elaine Sampaio Araujo, passei a participar como aluna ouvinte dos encontros da Oficina Pedagógica Matemática (OPM) e da disciplina do curso de Pedagogia, "Brinquedos e Brincadeiras na Educação Infantil". Ali fui apresentada à teoria histórico-cultural.

No início de 2017 retomei a escrita do projeto e passei a participar, ainda como aluna ouvinte, da disciplina "Metodologia do Ensino da Matemática", que fez com que meus olhos se "abrissem" em relação ao modo como o ensino da Matemática estava organizado em minha sala de aula e à forma como a teoria histórico-cultural possibilitava sua organização.

Em julho do mesmo ano, ingressei no programa, com o projeto intitulado "A avaliação nas aulas de Matemática: de ferramenta seletiva à ferramenta humanizadora do ensino", com o objetivo de compreender em que medida a atividade educativa, como uma possibilidade de desenvolvimento humano, poderia colocar professor e estudante em movimento de apropriação dos conceitos, sem que os sujeitos fossem marcados pelo ensino baseado "nas metas que se pretende alcançar".

Nesse percurso, a transformação pela qual meu projeto passou até que eu chegasse ao último ponto final atingiu não apenas meu objeto de pesquisa, uma vez que hoje essa dissertação tem outro título e outro objetivo. Mas afetou, principalmente, a pessoa que o escreve.

Nesta transformação, sinto a chegada das horas claras, ainda imersas nas horas escuras, a passagem da noite para o dia. Sinto o quanto essa hora assusta, pois o que estava encoberto pela noite ganha vida com o dia, e, assim, posso enxergar o que antes apenas sentia.

Existe, no círculo fechado diário do tempo e na infinita corrente das horas claras e escuras, uma hora, a mais nebulosa e indefinida, o limiar inapreensível entre a noite e o dia. Antes do amanhecer, há uma hora em que já é manhã, mas ainda é noite. Não há nada mais misterioso e incompreensível, mais enigmático e obscuro que essa passagem estranha da noite para o dia. A manhã chegou, mas ainda é noite: a manhã parece estar mergulhada na noite esparramada ao redor, parece nadar na noite. Nessa hora que dura, quem sabe, apenas uma fração insignificante de segundo, tudo, todos os objetos e rostos, 
parecem ter duas existências diferentes ou uma existência dupla, noturna e diária, na manhã e na noite. Nessa hora, o tempo torna-se instável e parece ser um aguaçal que ameaça desabar. A cobertura precária do tempo parece desfiar pelas linhas, desfaz-se. A inexpressividade do mistério aflito e incomum dessa hora assusta. Tudo, assim como a manhã, está imerso na noite que se apresenta e se evidencia por trás da linha da penumbra. Nessa hora, quando tudo é instável, obscuro e inseguro, não há sombras no sentido comum dessa palavra: reflexos escuros de objetos iluminados lançados ao chão. Mas tudo se apresenta como sombra, tudo tem o seu lado noturno. Essa é a hora mais aflita e mística; a hora do desabar do tempo e de rasgar a cobertura precária; a hora de desnudamento do abismo noturno sobre o qual se ergueu o mundo diurno; hora da noite e hora do dia. (VIGOTSKI, 1998, p. 323 apud PRESTES, 2013)

O movimento que abala aquilo que já estava consolidado e a incerteza que acompanha tudo que é novo têm me possibilitado "enxergar" a avaliação em sua essência, ou seja, como uma ação viva que medeia a relação entre os sujeitos diante do ensino, da aprendizagem e das possibilidades de desenvolvimento humano. 


\section{INTRODUÇÃO}

Ao tratar do conceito de Zona de Desenvolvimento Proximal, Vigotski (2001) ilustra seu pensamento com uma analogia: quando apresenta o trabalho do jardineiro e o desenvolvimento de uma semente, faz referência à relação professor-estudante e ao desenvolvimento infantil, destacando que o trabalho do professor relaciona-se ao trabalho do jardineiro, que não se detém apenas no processo natural de desenvolvimento da semente, mas organiza seu trabalho orientado pelo clima, pelas características do solo e pelos processos de adubagem. Do mesmo modo, o professor organiza seu trabalho, buscando modos para que os estudantes avancem do pensamento empírico para o teórico, pela apropriação dos conhecimentos historicamente produzidos.

Essa apropriação, semelhante ao processo de desenvolvimento da semente que, ao brotar, apresenta uma "nova" forma que antes não existia, mas foi preparada pelo jardineiro no degrau precedente, constitui-se como um salto qualitativo no pensamento, em que o "novo" desencadeia infinitas possibilidades para surgirem outras funções precisamente mais complexas.

Nessa analogia, o autor faz um alerta, dizendo que essa apropriação, por não representar o "fim" do processo, não pode ser comparada às flores ou aos frutos, mas apenas aos brotos, que, no decurso do desenvolvimento, possuem um longo caminho a percorrer.

Com efeito, o trabalho que se apresenta ao leitor corresponde ao broto de uma semente cuidada por diversos jardineiros que contribuíram para que ela irrompesse e penetrasse no solo, alicerçando-se para continuar sua jornada de desenvolvimento.

Assim, na busca por contribuir para a construção de princípios formadores da consciência docente, no âmbito do programa "Melhoria do ensino público", este trabalho vincula-se ao projeto de pesquisa "Gênese e desenvolvimento da organização do ensino de matemática em um município paulista", que, financiado pela Fundação de Amparo à Pesquisa do Estado de São Paulo (FAPESP), tem como objeto a organização do currículo para o ensino de Matemática nos anos iniciais do ensino fundamental.

Desse modo, nosso objeto centra-se na avaliação do ensino, significada nos preceitos da teoria histórico-cultural e objetivada por meio da atividade 
docente alicerçada nos princípios teórico-metodológicos da Atividade Orientadora de Ensino (AOE). Diante disso, nosso objetivo é compreender e explicitar a significação e a vivência da avaliação como unidade mediadora no processo em que o objeto do conhecimento humano, construído historicamente, revela-se às gerações posteriores por meio dos objetos de ensino.

Para essa significação, buscaremos considerar:

- A relação entre os sujeitos que vivem a avaliação no cotidiano escolar, bem como o espaço social que ocupam e os modos como compreendem a relação entre o ensino e as possibilidades de desenvolvimento humano.

- A orientação e a influência dos documentos curriculares de caráter mandatário sobre a organização do currículo e o trabalho docente.

- Algumas dimensões da avaliação e dos modos de avaliar implícitos nos materiais.

- A relação entre a avaliação, compreendida pela dimensão que pretendemos defender, e a organização intencional da atividade docente.

- A possibilidade de qualificar a avaliação como ação-instrumento intrínseco e mediador da relação ensino-aprendizagem.

Para isso realizamos um levantamento de textos e, a partir de clássicos, teses e artigos, selecionamos aqueles que poderiam contribuir para a construção de nossa base teórica, considerando o alinhamento à teoria histórico-cultural e aos pressupostos teórico-metodológicos da Atividade Orientadora de Ensino (AOE), bem como as discussões desses autores no que se refere ao espaço ocupado pelos sujeitos no cenário escolar; as concepções de ensino e de aprendizagem; os modos de organização do ensino; à função social da escola e o papel da avaliação no campo educativo. Alguns desses autores foram: 

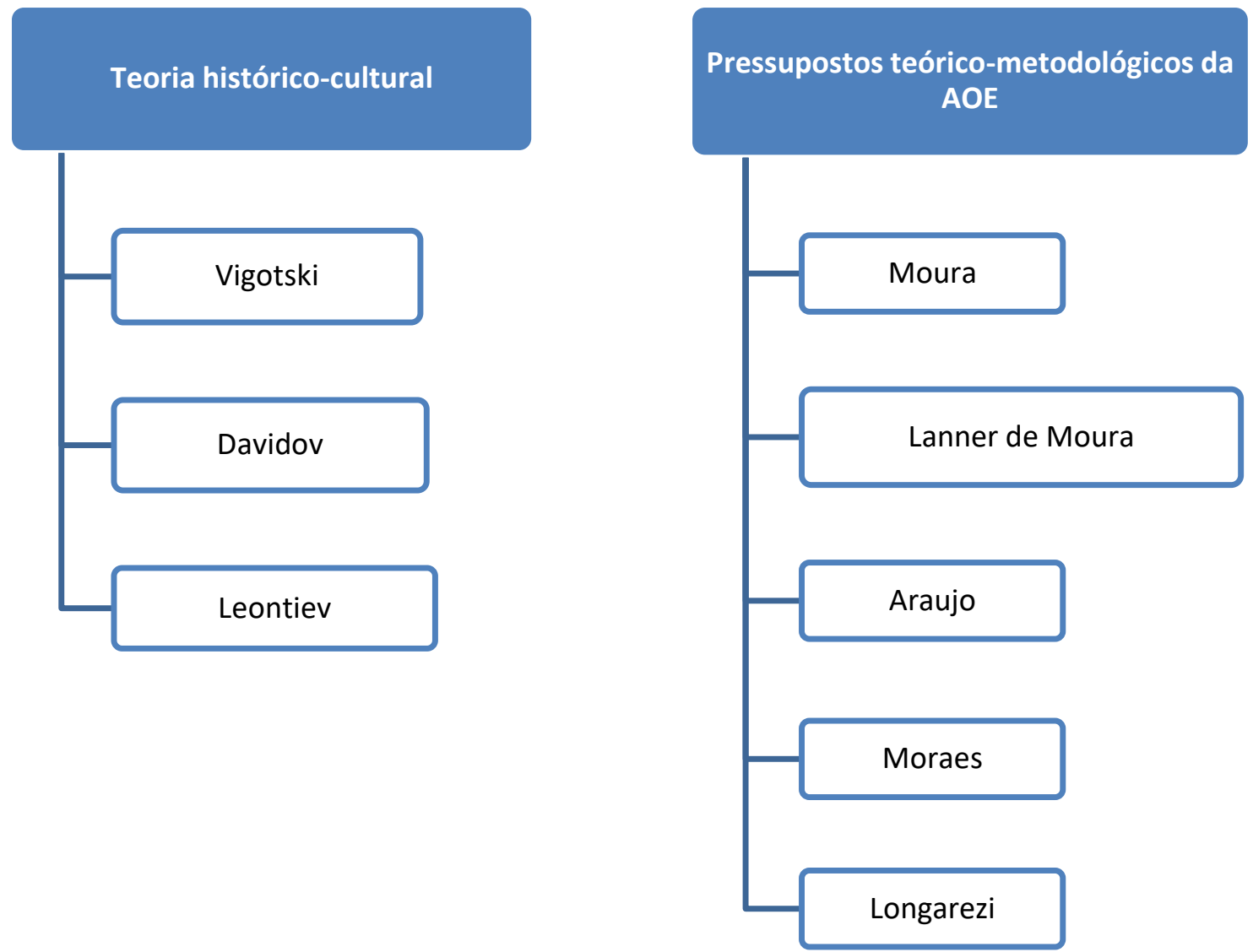

Do mesmo modo, o referencial empírico utilizado para análise da avaliação inserida na organização curricular, partiu do levantamento dos documentos orientadores da educação brasileira que, organizados a partir da Constituição Federativa de 1988, sob a influência da Declaração Universal dos Direitos Humanos (1948) e da Declaração de Jomtien (1990), carregam e reafirmam o lema "direito à educação":

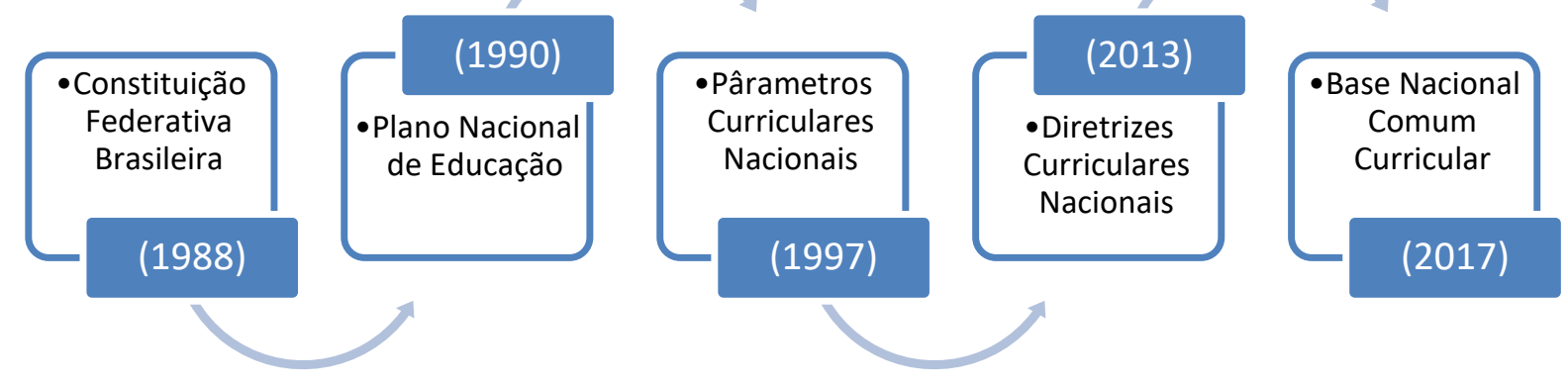

Utilizamos, também, modelos de "Avaliações Somativas" produzidos pela Secretaria Municipal de Educação do município campo no período entre 2016 e 2019, no qual tabulamos o conceito e os objetivos centrais de cada um dos 
exercícios elaborados para avaliar a aprendizagem dos estudantes matriculados do $1^{\circ}$ ao $5^{\circ}$; analisamos tarefas, como: construção de relógios de ponteiros, resolução de situações-problema, entre outras que, comumente, são propostas aos estudantes em uma sequência didática para o ensino das horas e, por fim, consideramos uma entrevista produzida por uma professora deste município no ano de 2020.

Nesse movimento, por compreendermos que nosso método de exposição revela nosso método de investigação, organizamos nosso trabalho em quatro elementos que consideremos interdependentes: Princípios, Propostas, Práticas e Possibilidades, no qual, temos a intenção de possibilitar ao leitor condições para que construa conosco sua compreensão sobre a perspectiva que pretendemos defender nas Considerações Finais, diante da mudança qualitativa da avaliação que, de medidora da aprendizagem, passa a revelar-se como mediadora entre ensino e aprendizagem.

Nesta lógica, no capítulo "Princípios - Sobre os sujeitos que vivem a avaliação e as relações que constituem as possibilidades de desenvolvimento humano", buscaremos: apresentar a relação entre o adulto e a criança que, no espaço escolar, apresenta-se na relação professor-estudante; e discutir o espaço social ocupado por esses sujeitos, bem como as concepções de aprendizagem que o permeiam. Nesse movimento nos fundamentaremos, inicialmente, em Charlot (1979), que apresenta esses sujeitos como parceiros sociais; e, após, em Vigotski $(2001,2007)$, que analisa os equívocos de três importantes concepções de aprendizagem de sua época, das quais discutiremos os vestígios, uma vez que ainda hoje se fazem presentes nos modos de organização do ensino. Destacaremos o conceito de Zona de Desenvolvimento Proximal, o qual, ao considerar as possibilidades de desenvolvimento prospectivo, compreendemos que se relaciona à compreensão que temos da avaliação como unidade mediadora na relação ensino-aprendizagem, com vistas ao desenvolvimento humano.

No capítulo seguinte, "Propostas - Um olhar para a BNCC e sua relação com o currículo, as práticas e as condutas", teceremos breve síntese histórica sobre os preceitos presentes nos documentos orientadores da educação brasileira, no período pós-Constituição de 1988, até a atual publicação da Base Nacional Comum Curricular, em 2017, destacando a gradual inserção de 
princípios subjacentes à avaliação que, caracterizada como métrica da aprendizagem, foi incorporada ao ensino como principal meio para verificação e validação de sua qualidade.

Nessa discussão, ancorados em Freitas $(2014,2016,2017)$ e outros autores que discutem as implicações desse modelo, trataremos de questões relacionadas ao "direito de aprendizagem" e à relação entre os elementos que integram a organização do ensino. Discutiremos também os princípios de "uma boa situação de aprendizagem", abordando as habilidades previstas pela BNCC para o ensino das horas, a partir das contribuições de Davidov (2017) sobre sua análise acerca dos princípios didáticos da escola tradicional e dos possíveis princípios da escola futura, lugar em que, para nós, "avaliar", revela-se como possibilidade de educação, em que o ensino se organiza com vistas à construção, nos sujeitos, de "uma personalidade criativa e multilateralmente desenvolvida" (DAVIDOV, 2017, p. 222).

No capítulo "Práticas - Algumas dimensões da avaliação: da pseudointencionalidade pedagógica à formação da consciência docente", discutiremos as características subjacentes ao "instrumento de medição", as quais, em sua dimensão instrumental e operacional, desencadeiam certa pseudointencionalidade pedagógica sobre as práticas e as condutas do professor em relação ao papel dessa ferramenta na organização do ensino. De encontro a essas dimensões, apresentaremos a avaliação em sua dimensão dialética e, alicerçados nos princípios da teoria histórico-cultural, a defenderemos como ação-instrumento, intrínseca à relação ensinoaprendizagem, constituindo-se como possibilidade de análise e síntese da atividade docente, pois compreendemos que, como unidade mediadora entre 0 ensinar e o aprender, ela nos permite regular situações desencadeadoras de aprendizagem, com vistas à apropriação dos nexos próprios do pensamento teórico, via ensino escolarizado.

Ainda nesse capítulo, abordaremos desde os materiais utilizados pela Secretaria Municipal de Educação do município campo para acompanhamento das aprendizagens dos estudantes a partir de 2016, até a organização de novas práticas que, em 2020, considerando o estado de calamidade sanitária em que vivenciamos a modalidade remota do ensino por medidas de distanciamento 
social, são consideradas por nós como exemplo da avaliação dialética na atividade de ensino.

No capítulo "Possibilidades - A avaliação dialética: da medição à mediação", ancorados principalmente em Leontiev (2004), que apresenta a Teoria da Atividade, além de Moura et al. (2010), Moura e Araujo (2018) e outros autores que tratam dos fundamentos teórico-metodológicos subjacentes à Atividade Orientadora de Ensino, discutiremos os princípios da Avaliação Dialética objetivada ao longo do planejamento, da realização e do desfecho de uma atividade que, no decurso da relação ensino-aprendizagem, leva à outra. Para isso, apresentaremos uma cena que, apesar de imaginária, possui certa recorrência no dia a dia daqueles que ocupam as salas de aula. Assim, com auxílio de uma história virtual, poderemos discutir um exemplo de tomada de consciência em relação às etapas da atividade de ensino, de modo que a medição da aprendizagem sai de cena, para dar espaço à avaliação compreendida como possibilidade de mediação do ensino.

Por último, nas Considerações Finais, traremos nossa voz para apresentar o movimento de análise e síntese em defesa de uma avaliação intrínseca à atividade pedagógica e, por isso, unidade entre o ensino e a aprendizagem, objetivando-se como mediadora entre os sujeitos e os objetos do conhecimento humano construídos historicamente e apresentado às novas gerações como objetos do ensino.

No Quadro 1 apresentamos um resumo, no qual, para cada elemento descrito na lógica de exposição que construímos, explicitamos ações de pesquisa que, alicerçadas ao referencial teórico escolhido, permitiram a análise e elaboração de sínteses sobre a compreensão do nosso objeto: a avaliação do ensino.

\begin{tabular}{|c|l|}
\hline \multicolumn{2}{|c|}{ Lógica de exposição da pesquisa } \\
\hline $\begin{array}{c}\text { Elementos da } \\
\text { pesquisa }\end{array}$ & \multicolumn{1}{c|}{ Ações de pesquisa } \\
\hline Princípios & $\begin{array}{l}\text { Explicitar os fundamentos orientadores da nossa compreensão } \\
\text { sobre os sujeitos que vivenciam a avaliação e a relação ensino- } \\
\text { aprendizagem. }\end{array}$ \\
\hline
\end{tabular}




\begin{tabular}{|c|c|}
\hline Propostas & $\begin{array}{l}\text { Analisar os documentos orientadores da educação brasileira com } \\
\text { intuito de compreender como os instrumentos avaliativos foram } \\
\text { inseridos ao cenário escolar no papel de principais meios para se } \\
\text { verificar a aprendizagem. }\end{array}$ \\
\hline Práticas & $\begin{array}{l}\text { Analisar possíveis dimensões da avaliação: } \\
\text { - Instrumental; } \\
\text { - Operacional; } \\
\text { - Dialética. }\end{array}$ \\
\hline Possibilidades & $\begin{array}{l}\text { Compreender o movimento de análise e síntese em que a } \\
\text { avaliação se constitui como mediadora que possibilita a } \\
\text { aproximação entre os objetos do conhecimento humano e os } \\
\text { sujeitos. }\end{array}$ \\
\hline Considerações finais & $\begin{array}{l}\text { Defesa de uma avaliação que, como ação-instrumento } \\
\text { intrínseca à atividade pedagógica, revela-se como unidade } \\
\text { mediadora, possibilitando aos sujeitos condições para que se } \\
\text { apropriem dos objetos do conhecimento humano construídos } \\
\text { historicamente. }\end{array}$ \\
\hline
\end{tabular}

QUADRO 1. Lógica de exposição da pesquisa. Organizado pela autora.

A necessidade em se discutir a avaliação à luz de uma perspectiva teórica que não a compreende, unicamente e somente, como métrica, leva-nos a apreensão de uma avaliação que se constitui como ação-instrumento. Dito de outra forma, contribui para análise da realidade concreta do lugar da avaliação no contexto das salas de aula.

E, apesar desse objeto, a avaliação do ensino, configurar-se como "motivo particular" desta pesquisadora, acreditamos que a discussão sobre a temática se revela como elemento de relevância social, pois, ao considerarmos a necessidade de análise e síntese da organização intencional de atividade de ensino (MOURA et al., 2010), contribuímos para a concretização da função social da escola que, ao sobrepujar a formação cidadã e a qualificação para o trabalho, proporciona "o desenvolvimento das capacidades humanas (simbólicas, valores, sentimentos, emoções, motivos e outros) que permitem e favorecem a formação integral do sujeito" (CARDOSO; PUENTES, 2021, p.303).

Nesse sentido, deslocar a avaliação de sua dimensão métrica, significa compreendê-la em uma perspectiva na qual lhe é atribuída uma nova forma e 
novo um conteúdo, considerando-a, não mais como instrumento estático, mas, como elemento dinâmico que se objetiva no movimento dialético. 


\title{
1. SOBRE OS SUJEITOS QUE VIVEM A AVALIAÇÃO E AS RELAÇÕES QUE CONSTITUEM AS POSSIBILIDADES DE DESENVOLVIMENTO HUMANO
}

\author{
Um meio, quando é escrito em números, sempre quer dizer \\ "metade". Mas quando é escrito em letras também pode querer \\ dizer "um jeito" (FALCÃO; MASSARINI, 2001, p. 7, grifo \\ nosso).
}

A educação brasileira, ao longo dos anos, teve sua institucionalização marcada por diferentes objetivos que, assim como podemos observar em Paludo (2015) e Lacerda (2006), perpassaram desde as necessidades de uma sociedade em transformação até a busca pela "mão de obra" especializada que atendesse aos interesses de seu processo de atualização.

Paludo (2015, p. 221), ao discutir sobre a legitimação da Educação Popular (EP) como forma de resistência e emancipação humana, trata do processo de constituição do capitalismo e analisa os modos de invasão, expropriação, exploração e colonização de países da América Latina, como no caso brasileiro, em que essa constituição se deu pelo "quase total extermínio dos índios e a escravidão", destacando os processos de luta e emersão de líderes populares, como Paulo Freire (1921 - 1997) que, no que diz respeito à educação como meio para transformação social, defendia a constituição de uma dinâmica política em que se poderiam construir outros modos de relações sociais, para além daqueles de exploração e alienação dos sujeitos e das condições em que esses se encontravam inseridos.

Lacerda (2006) trata das redes de relações que possibilitaram a ascensão de jovens de camadas populares, pertencentes a famílias com pouca ou nenhuma escolaridade, por meio da conquista do diploma acadêmico, e apresenta exemplo dessa busca pela "mão de obra" especializada, ao descrever o processo de organização de uma das instituições de ensino superior almejada por estes estudantes e, posteriormente, frequentada por eles. Desde o plano de criação dessa instituição, objetivava-se a formação de profissionais altamente qualificados para produção de tecnologia nacional, uma vez que, com isso, o País poderia afirmar-se em nível de desenvolvimento industrial, assim como de segurança nacional: 
A história do ITA começa a ser construída a partir do esboço do plano
de criação do Centro Técnico da Aeronáutica, em meados da década
de 1940 [...]. Nesse plano, previa-se a criação do ITA, instituição de
ensino e pesquisa pura, como um dos institutos do centro Técnico da
Aeronáutica, hoje denominado Centro Técnico Aeroespacial (CTA).
Pretendia-se, assim, garantir o desenvolvimento da indústria
aeronáutica brasileira por meio da formação de uma elite de
engenheiros. [...] Desde a década de 1940, a importância da tecnologia
e a necessidade de produzi-la nacionalmente eram vistas como
essenciais para o Brasil, tanto em termos de desenvolvimento
industrial, quanto de segurança nacional. (LACERDA, 2006, p. 48- 49)

Nesse sentido, tendo em vista que a educação escolar, ao longo do seu processo de institucionalização, também passou por regimes de democratização possibilitados por diferentes políticas públicas que, em síntese, previam direitos de acesso (CURY, 2002), a escola, de acordo com Moraes (2008), veio a fazer parte da vivência de grande parcela da população, o que, em consequência, fez com que os instrumentos utilizados nesses espaços se tornassem cada vez mais comuns, como no caso da avaliação:

$\mathrm{Na}$ atualidade, é comum, ao referir-se à avaliação, imediatamente, as pessoas relacionarem-na com a escola. Esta aproximação, na verdade, deve-se ao fato de que a escola tem feito parte da maioria da população, tendo em vista que esta tem sido a forma que a sociedade encontrou para a transmissão dos conhecimentos produzidos historicamente às novas gerações. A avaliação está presente em vários momentos da trajetória escolar. (MORAES, 2008, p. 25)

Portanto, a avaliação não pode ser compreendida como uma ação desvinculada da luta pela modificação da forma escolar, uma vez que a questão central desta ação não está na diferenciação entre os critérios que constituem e diferenciam uma avaliação contínua, processual, pontual ou somativa, mas na dimensão de uma ação mediadora no processo que se concretiza entre o ensino e a aprendizagem, com vistas às possibilidades de desenvolvimento humano (FREITAS, 2010), o que para nós se configura no par dialético, em que a avaliação é compreendida como "ação-instrumento", fazendo romper com a compreensão que a identifica somente como um instrumento próprio dela.

A partir dos princípios da teoria histórico-cultural, neste capítulo buscaremos "um jeito" de apresentar a avaliação como uma ação de prospecção do desenvolvimento humano e discutiremos, inicialmente, em que medida as relações entre a criança e o adulto permitem e favorecem vivências para que, como sujeitos igualmente participantes da relação ensino-aprendizagem, 
possam se desenvolver, uma vez que, assim como Vigotski (2018, p. 90, grifo do autor) explica, o homem é "ser social e fora da relação com a sociedade, jamais desenvolveria as qualidades, as características que são resultado do desenvolvimento metódico de toda humanidade".

Partindo da tese de que o homem se humaniza na relação com o outro e com seu meio, ao passo que se apropria dos conhecimentos culturalmente construídos, passaremos a analisar os elementos presentes na relação entre as concepções de aprendizagem e desenvolvimento que, na relação professorestudante - lugar em que a avaliação, como componente intrínseco à atividade pedagógica, coloca-se como mediadora do planejamento, da realização e do desfecho das ações dos sujeitos - venham possibilitar a apropriação dessa herança cultural.

Fundamentando-nos principalmente em Vigotski (2001, 2007), analisaremos alguns exemplos de "expressões" comumente ditas por professores, que revelam vestígios de três grandes posições teóricas criticadas pelo autor em sua época, mas que acreditamos que ainda hoje influenciem os modos de organização do ensino, pois, ao transparecerem nestas falas, alinhamse tanto às práticas e às condutas que alicerçam e organizam o trabalho docente, como aos modos com que esses professores concebem a aprendizagem.

Para contrapor, discutiremos o conceito de zona de desenvolvimento proximal (VIGOTSKI, 2001), analisando em que medida ele se revela na organização do ensino e, ainda, a forma como a avaliação nesta relação pode ser significada, possibilitando condições de humanização, ao passo que professor e estudante se apropriam dos bens culturais.

Finalizaremos o capítulo, discutindo em que medida a avaliação pode descolar-se de seu papel de instrumento medidor da aprendizagem para constituir-se como mediadora e configurar-se, integralmente, como ação intrínseca ao humano e, em consequência, à atividade de ensino e à atividade de aprendizagem, mediada pela apropriação do conhecimento humano, com vistas às possibilidades de desenvolvimento multilateral (DAVIDOV, 2017; LEONTIEV, 2004). 


\subsection{Da relação entre a criança e o adulto}

A criança que monta um cabo de vassoura e imagina-se cavalgando um cavalo; a menina que brinca de boneca e imagina-se a mãe; a criança que, na brincadeira, transforma-se num bandido, num soldado do Exército Vermelho, num marinheiro - todas essas crianças brincantes representam exemplos da mais autêntica e verdadeira criação. [...] As brincadeiras infantis, frequentemente, são apenas um eco do que a criança viu e ouviu dos adultos. (VIGOTSKI,2017, p. 1617)

Comumente, a concepção legal que compreende o período da vida instituído como infância defende esse momento como aquele em que o sujeito, habitualmente denominado pela nomenclatura "criança", necessita receber proteção de toda a sociedade contra as diferentes formas de violência. Em nosso país, esta normativa, regida pela Constituição Federal de 1988, entrou em vigor a partir de 1990, com a lei $n^{\circ} 8.069$, do Estatuto da Criança e do Adolescente ECA -, que determina, além de direitos fundamentais dos menores, sanções quando esses direitos são violados.

Todavia, esta compreensão acerca da infância surge como fruto da transformação do papel desses sujeitos na sociedade, pois, como a história aponta, antes da Idade Média e mesmo em séculos posteriores a ela, pouco se sabia sobre as crianças e o espaço ocupado por elas, uma vez que apenas em meados do século XIX, com a criação das primeiras leis de proteção, é que elas deixaram de ser vistas como adultos em miniatura, para tornar-se, de fato, "crianças" (TOMÁS, 2002).

A propósito, de acordo com Prestes (2013), muitos historiadores e estudiosos dessa etapa da vida têm contribuído para a construção da chamada Sociologia da Infância, que, de modo suscinto, na busca por entender a sociedade por meio do estudo da criança, tem ganhado corpo no campo das pesquisas científicas, defendendo a ideia de que a criança representa uma "atora social", enquanto "infância" é apenas uma categoria do desenvolvimento construída socialmente.

Todavia, não podemos relativizar o papel da criança e da infância, buscando uma relação direta entre o que é defendido pela Sociologia Infantil e os conceitos apresentados por Vigotski ao longo de sua obra. Nesse sentido, 
vale ressaltar que estabelecer tal relação não corresponde ao objeto de estudo deste trabalho e que, para estudá-la, necessitaríamos nos dedicar a uma vasta revisão bibliográfica, a fim de encontrarmos elementos que pudéssemos utilizar como subsídios para este fim. Entretanto, utilizamo-nos desta introdução para destacar nossa compreensão sobre a criança como sujeito social, que se desenvolve à medida que participa de diferentes formas de colaboração e interação com os sujeitos do meio social que a rodeia (VIGOTSKI, 2001).

Desse modo, sob a luz da teoria histórico-cultural, nos concentraremos, inicialmente, em compreender a relação entre a criança e o adulto, uma vez que, assim como aponta Leontiev (2004, p. 183), defendemos que "as relações da criança com o mundo dos objetos são sempre, inicialmente, mediatizadas pelas ações do adulto", o que, para este estudo, se configura na relação professorestudante. E é a escola um dos principais espaços de vivência ocupado por esses sujeitos.

Nessa direção, recorremos a Bernard Charlot (1979), que destaca as características das transformações na relação professor-estudante e apresenta três distintas concepções da pedagogia, que ele assim denomina: pedagogia tradicional, pedagogia nova e pedagogia social.

Para Charlot (1979), a pedagogia tradicional percebe a criança como um ser inferior ao adulto. Dominada por sua sensibilidade e por seus desejos, além da falta de experiência e razão, no qual, ela se torna suscetível ao erro. O adulto, em sua superioridade, teria o papel de guiá-la, domando-lhe a "natureza selvagem [...] e apresentando-lhe modelos ideais que formariam sua razão e sua personalidade" (CHARLOT, 1979, p. 244).

Semelhante ao que Tomás (2002) apresenta sobre os escritos do filósofo Locke (1632 - 1704), que baseava sua teoria no conceito de Tábua Rasa, segundo o qual a criança, como uma espécie de cera maleável, permitia ao adulto condições para "moldá-la", a pedagogia tradicional, por considerar o adulto superior à criança, defendia que ele poderia guiá-la, de modo a refrear sua natureza e, assim, formá-la para que pudesse ser inserida no meio social.

Já para pedagogia nova, em oposição à pedagogia tradicional, Charlot (1979) reporta o surgimento de uma inversão em relação ao espaço ocupado por estes sujeitos: a criança, antes vista como alguém que necessitava ser "moldada", passa a ser percebida como um ser espontâneo, criativo e inocente, 
enquanto o adulto, ao perder seu papel de "escultor", torna-se aquele que oferece prejuízo à especificidade infantil, indica às crianças modelos estereotipados e leva-as a se desviarem de sua bondade natural.

Tal caracterização, também observada por Tomás (2002) nos escritos do francês Rousseau (1712 - 1778), destaca que, para este autor, a criança, como um ser naturalmente bom, contamina-se com a maldade no contato com os outros, o que a leva, ao longo da vida, a impregnar-se dos padrões negativos da sociedade e, com isso, perder sua pureza.

A pedagogia tradicional, a pedagogia nova e as sínteses apresentadas por Tomás (2002) sobre os pensamentos dos filósofos Locke e Rousseau, embora possuam significações opostas acerca do espaço social ocupado pela criança e pelo adulto, identificam a infância de modo desvinculado da idade adulta e consideram a existência de uma natureza infantil muito peculiar: ora selvagem, ora inocente.

De acordo com Charlot (1979), ambas as concepções apresentam um conceito equivocado, pois seria impossível estudar a infância como elemento isolado, para depois compará-la com outras variáveis. Isso porque, como o autor afirma, a relação entre o adulto e a criança representa uma relação social, em que essa etapa do desenvolvimento deve ser entendida não como elemento da "natureza infantil", mas como parte de uma "condição infantil", já que

não se trata neste caso simplesmente da substituição de uma palavra por outra. A ideia de natureza infantil remete a características que têm um valor absoluto e universal: a criança, em si, é selvagem, inocente, espontânea, indisciplinada, etc. A ideia de condição infantil faz referência a uma situação específica da infância sem, com isso, definir qualidades ou comportamentos que se encontram inevitavelmente em toda criança. (CHARLOT, 1979, p. 252-253)

Dessa maneira, nossa intenção não é de observar características que sobressaem nessa ou naquela etapa da vida dos sujeitos, mas analisar o modo como a avaliação, na relação professor-estudante, pode configurar-se como unidade mediadora entre o ensino e a aprendizagem, contribuindo para 0 desenvolvimento de uma "autêntica" atividade de ensino e "autêntica" atividade de aprendizagem que, em consequência, possibilita a apropriação dos nexos próprios do pensamento teórico. 
É importante destacarmos que defendemos essa autenticidade na concepção apresentada por Davydov (1999), que define como autêntica aquela atividade que 1) envolve os atributos - necessidade, motivo, objetivos, condições, instrumentos, ações e operações - explicitados por Leontiev (2004), ao tratar do conceito de atividade; e 2) transforma a realidade dos sujeitos a partir da ação que, necessariamente, implica a criação ou a reformulação dos elementos.

Portanto, nossa compreensão acerca da relação entre o professor e o estudante assemelha-se ao que Charlot (1979) inclui na pedagogia social, em que, diferentemente das anteriores, adulto e criança aparecem como parceiros, cuja personalidade e interesse não estão marcados por uma natureza infantil, mas se constituem mediante as condições materiais e os modelos que lhes são apresentados, bem como os meios sociais em que vivem e dos quais almejam fazer parte.

Assim, ao abordarmos a relação entre a criança e o adulto como parceiros, nós o fazemos, considerando-a como elemento imprescindível para o desenvolvimento humano, pois, alicerçados na base da teoria histórico-cultural, compreendemos que isso só é possível a partir de vivências mediadas pelas relações sociais caracterizadas por mudanças qualitativas que transformam 0 sujeito, à medida que este transforma e é transformado pelo meio. Essa mudança qualitativa, como explica Vigotski (2018, p. 33), representa:

\footnotetext{
[...] o aspecto mais importante que faz com que 0 desenvolvimento seja desenvolvimento, que the atribui uma qualidade sem a qual não pode ser chamado de desenvolvimento, que é o surgimento do novo. Se, diante de nós, temos um processo no decorrer do qual não surge nenhuma nova qualidade, nenhuma nova particularidade, nenhuma nova transformação, então, é claro, não podemos falar em desenvolvimento no sentido próprio da palavra.
}

Para aprofundarmos nossa compreensão a respeito do conceito de desenvolvimento, recorremos a Prestes (2013), importante tradutora das obras de Vigotski do russo para o português. Ela explica que, para a teoria históricocultural, o desenvolvimento, como surgimento do novo, representa um processo imprevisível, envolvendo períodos críticos, sucedidos por outros mais estáveis, 
os quais, de modo não linear, são cruciais para que o sujeito passe de uma etapa para outra nesse processo dialético do desenvolvimento humano.

Assim, ao passo que nos apropriamos do conceito de desenvolvimento como resultado de um processo ininterrupto de surgimento do novo, compreendemos que este não está subordinado somente às leis biológicas e hereditárias, bem como não é regido unicamente pela influência do meio, que "contamina ou molda" de acordo com normas e padrões de uma época, como expresso pelos filósofos Locke e Rousseau.

O novo se constitui por meio de uma unidade composta por todos esses elementos, e tal unidade, mais do que uma combinação mecânica, "não é permanente, não é algo dado para todo sempre e sumariamente determinado. É uma unidade mutável, diferenciada, constituída de diversas formas e requer, a cada vez, um estudo completo" (VIGOTSKI, 2018, p. 73).

Nesse sentido, Leontiev (2004, p.282) trata da influência dos fatores biológicos para o desenvolvimento, explicando que

o homem não está evidentemente subtraído ao campo de ação das leis biológicas. O que é verdade é que as modificações biológicas hereditárias não determinam o desenvolvimento sócio-histórico do homem e da humanidade; este é doravante movido por outras forças que não as leis da variação e da hereditariedade biológicas.

Assim, compreendemos que fatores hereditários ou biológicos, bem como aqueles que estão presentes no meio, apesar de se refletirem no desenvolvimento, não o determinam, de modo que fatores embrionários ou marcados socialmente por condições "dadas" passam para segundo plano, não pelo que contêm em si, mas pelas vivências construídas na relação entre os sujeitos, que não se dão igualmente em todas as faixas etárias, assim como não acontecem de modo semelhante para todos. Ou seja:

Um evento que tem determinado significado desempenha um papel diferente numa idade específica. Todavia, dois anos depois, começa a ter outro significado e a desempenhar outro papel por forças de mudança da criança. Ou seja, a relação da criança com aqueles eventos do meio mudou. Valendo-nos de exemplos que vimos quando analisamos crianças, podemos dizer, com mais precisão ou exatidão, que os momentos essenciais para definição da influência do meio no desenvolvimento psicológico, no desenvolvimento da 
personalidade consciente, são a vivência. (VIGOTSKI, 2018, p.75, grifo do autor)

Diante do expresso por Vigotski (2018), podemos afirmar que a experiência humana é composta por diferentes vivências que contribuem para a construção de significações, e estas, de modo dinâmico, nos movimentam em busca da satisfação de necessidades espirituais (de estética, de cultura) que surgiram com a vida em sociedade, superando aquelas consideradas necessidades básicas de sobrevivência (LEONTIEV, 2017).

Nesse movimento, a escola, como importante espaço de construção de vivências, configura-se como privilegiada, no que diz respeito às condições que, por meio do conhecimento organizado pelo professor, criam oportunidades para que as gerações se apropriem do conhecimento construído pela humanidade, possibilitando, como temos afirmado, o dinâmico surgimento do novo (VIGOTSKI, 2017). Rigon, Asbar e Moretti (2016, p. 32-33) destacam ainda que

\begin{abstract}
a educação é entendida, na perspectiva da teórica que assumimos, como via para o desenvolvimento psíquico e principalmente humano e não como mera aquisição de conteúdos ou habilidades específicas. É com base nesse posicionamento que afirmamos a necessidade da presença da educação sistematizada em todas as fases do desenvolvimento, dado que ela permite uma organização consciente dos processos de formação dos indivíduos, via organização intencional de um ensino que permita aos sujeitos a apropriação dos conhecimentos, de habilidades e de formas de comportamento produzidos pela humanidade. Nesse sentido, a escola é instituição privilegiada no que diz respeito às possibilidades de humanização do homem.
\end{abstract}

Diante dessa relação, ao passo que a avaliação se configura como instrumento externo à atividade pedagógica e legitimadora dos "objetivos escolares" perante a sociedade, constituindo-se como orientadora da relação professor-estudante, nós a consideramos como obstáculo, no que diz respeito ao papel da escola do modo como o defendemos, pois, contrariamente a essa perspectiva, no espaço escolar, a avaliação deve se configurar como mediadora entre o ensino e a aprendizagem. Isso porque, assim como explica Davydov (1999), se, por um lado, ela possibilita ao professor meios para organizar sua atividade, por outro, propicia ao estudante condições para que se envolva nessa relação, mobilizando-o em direção à apropriação do conhecimento. 
Sobretudo, a avaliação, como unidade mediadora, necessita ser compreendida como intrínseca às relações construídas nesse espaço, para que o professor possa organizar conscientemente sua prática e, com isso, promover situações intencionalmente direcionadas a esse fim, ou seja, importa mobilizar no estudante o desenvolvimento de sua atividade: a atividade de aprendizagem (MOURA et al., 2010).

A avaliação, ao configurar-se como unidade mediadora entre o ensinar e o aprender, deve levar à construção de vivências que contribuirão para o desenvolvimento futuro dos sujeitos, não por este ou aquele momento, "tomado independente da criança, que pode determinar sua influência no desenvolvimento posterior, mas o momento refratado através da vivência da criança" (VIGOTSKI, 2018, p. 75), o que para nós é compreendido pelo conceito apresentado por Vigotski (2001) como "zona de desenvolvimento proximal".

Para discutirmos este conceito, a seguir analisaremos a relação entre as concepções de aprendizagem e de desenvolvimento, sob a luz do que temos defendido acerca do papel social ocupado pelo professor e pelo estudante e analisaremos as possibilidades de desenvolvimento humano a partir das concepções fundantes do fazer pedagógico que, em consequência, orientam os processos que constituem a relação ensino-aprendizagem.

\subsection{Da relação entre as concepções de aprendizagem e de desenvolvimento humano}

Ao abordarmos o papel da criança e do adulto na esfera pedagógica, a partir da relação professor-estudante, inicialmente buscamos enfatizar os importantes elementos que sustentam a relação entre os sujeitos e parceiros mais experientes, destacando o conceito de desenvolvimento à luz da teoria histórico-cultural, de modo que, ao ser compreendido no sentido próprio da palavra, ele possa fundamentar nosso estudo acerca das concepções que tratam da aprendizagem.

Em relação ao conceito de aprendizagem, Prestes (2013) explica que Vigotski se refere a ele, recorrendo à palavra em russo obutchénie que, traduzida para o português a partir de versões norte-americanas, relaciona-se à palavra "instrução" que, no cenário brasileiro, carrega uma conotação negativa, 
comumente ligada à transmissão e à aquisição do conhecimento pelo sujeito passivo.

A autora destaca também que, para as teorias que a estudam, a aprendizagem se relaciona a processos psicológicos do próprio sujeito, em que importa o resultado a que se quer chegar, enquanto, para Vigotski e seus colaboradores, obutchénie, de modo mais completo, refere-se a uma atividadeguia, cujo sentido se encontra nela mesma.

Na busca por compreendermos de modo mais tangível o significado dessa "transliteração da palavra russa обучениe" (LONGAREZI; DIAS, 2019, p. 457), recorremos as palavras de Longarezi e Puentes (2017, p. 12), no qual as autoras afirmam que

[...] a obutchénie é um tipo especial de atividade docente que contempla, ao mesmo tempo, o trabalho ativo, colaborativo, intencional, comunicativo, motivado e emocional, tanto do professor quanto dos alunos, portanto do ensino e da aprendizagem, com vista ao desenvolvimento pleno das qualidades humanas dos sujeitos".

Com isso, na relação professor-estudante, compreendemos obutchénie como a unidade entre o ensino e a aprendizagem, em que a atividade de ensino, realizada pelo professor, e a atividade de aprendizagem, realizada pelo estudante, ligam-se como elementos indissociáveis, aproximando-se do que compreendemos acerca da relação ensino-aprendizagem. Como explicam Longarezi e Dias (2019), a partir da tradução que realizam das obras de Davidov (1996) do russo para o português, obutchénie se constitui na interação entre professor e estudante, destacando ainda que, se tal relação for compreendida como "atividade", obutchénie, então, configura-se como uma correlação entre as atividades realizadas pelo professor e pelo estudante.

Desse modo, ao concretizar-se na relação ensino-aprendizagem, no sentido do termo perejivaine, que "não diz respeito a uma particularidade da criança, nem ao ambiente social em que ela se encontra, mas à relação entre os dois" (PRESTES, 2010, p. 120), o desenvolvimento de uma real obutchénie, possibilitará vivências que promoverão o ininterrupto surgimento do novo, ou seja, do desenvolvimento humano (VIGOTSKI, 2001).

Com efeito, as experiências vividas entre a criança e o adulto, na relação professor-estudante, coincidem com a tese vigotskiana de que o conhecimento 
surge antes no social, para depois ser internalizado pelos sujeitos, tornando-se um processo individual que perpassa a relação ensino-aprendizagem, marcado por processos dialéticos que podem ser rápidos ou vagarosos; intensos ou fracos; progressivos ou regressivos. Subordinados a irregularidades internas próprias, primeiramente são vivenciados na relação com o outro, para serem depois interiorizados pelos sujeitos (PRESTES, 2013).

Diante disso, faz-se necessário para nosso estudo analisar em que medida a avaliação, qualificada como ação inerente à atividade humana, pode ser considerada também inerente à atividade pedagógica e, por isso, mediadora da relação ensino-aprendizagem, como via para possibilitar a interiorização do conhecimento humano pelos sujeitos.

Há de se ressaltar que, assim como Vigotski (2001) explica, mesmo crianças pequenas ou em idade pré-escolar já possuem, no seio familiar, as primeiras relações que lhes permitem construir significados a partir de vivências que as constituirão, para que se desenvolvam e se tornem sujeitos participantes nos espaços que ocupam. Isso indica que, mesmo limitado, o restrito "grupo social" representado pela família pode promover situações para que o desenvolvimento ocorra a partir dos primeiros processos de comunicação entre a criança e o adulto.

Nas palavras de Vigotski (2007), isso pode ser compreendido pela história construída anteriormente ao aprendizado escolar, ou seja:

\footnotetext{
Qualquer situação de aprendizado com a qual a criança se defronta na escola tem sempre uma história prévia. Por exemplo, as crianças começam a estudar aritmética na escola, mas muito antes elas tiveram uma experiência com quantidade - tiveram de lidar com operações de divisão, adição, subtração e determinação de tamanho. (VIGOTSKI, 2007, p. 94)
}

Entretanto, não significa que o conhecimento construído nessas primeiras experiências seja suficiente para o desenvolver o pensamento teórico, uma vez que, na relação em família, a interação ocorre naturalmente a partir de situações que não foram planejadas ou organizadas para esse fim, pois, como explicam Moura et al. (1996), mesmo que a criança, em seu núcleo familiar, tenha contato com os números, não são garantidas a ela condições para apropriação do 
conceito numérico, pois nessa experiência familiar, a criança observa e interage com o número pronto, cuja construção sócio-histórica lhe é ignorada:

O número aparece assim para ela como um elemento cultural já
construído, cujos elementos de construção ela não conhece. Por
isso, se uma criança sabe contar e até escrever números
grandes, isso não significa necessariamente que ela tenha uma
compreensão matemática do número. Esta compreensão
precisa ser construída na escola. (MOURA et al., 1996, p. 24)

Isso nos mostra que o ingresso da criança na escola, ao passo que amplia suas relações com outros adultos e com crianças mais experientes, insere-a em situações de ensino planejadas e organizadas que assumem papel mediador para que ela possa, a partir de uma situação educativa sistematizada, apropriarse dos conhecimentos produzidos pela humanidade, o que constitui a escola, como apontamos anteriormente, como "instituição privilegiada no que diz respeito às possibilidades de humanização do homem" (RIGON; ASBAR; MORETTI, 2016, p.33).

Diante disso, pensar o espaço escolar significa levar em consideração os modos de produção do conhecimento a partir da forma como se organizam, bem como os instrumentos que legitimam esse espaço perante a sociedade, fazendoo cumprir sua função social, que, à luz da teoria histórico-cultural, relaciona-se à ideia de expandir o conhecimento científico, proporcionando "a compreensão do significado de seus conceitos, em que implica criar condições para que as gerações posteriores compreendam a necessidade humana que gerou a criação do conceito, bem como seu processo de desenvolvimento" (RIGON; ASBAR; MORETTI, 2016, p. 74).

Como vemos, os instrumentos que compõem a organização do ensino se configuram como importantes elementos a serem discutidos, pois 0 distanciamento dos professores dos processos de produção das propostas curriculares infunde a falsa impressão de que o trabalho pedagógico não possui relação com as teorias educacionais, e essa percepção recai sobre os modos de que muitos se utilizam para organizar a prática, porque seguem os modelos que tiveram enquanto estudantes, por não conhecerem a teoria que thes dê as condições objetivas para organizar suas atividades (SOUSA, 2004). Catanante (2013, p. 62) nos confirma que, 
se ele [o professor] não é formado e/ou orientado sob uma concepção que destaque o seu papel enquanto agente organizador do ensino, dificilmente perceberá a importância de sua ação/mediação, prevalecendo como executor de atividades prontas situadas no material e de uma política pensada por outros.

Desse modo, ao passo que o professor não se reconhece como agente organizador, comumente evoca para si o discurso em que a teoria, ao opor-se à prática, caminha em direção oposta aos objetivos presentes na relação ensinoaprendizagem, sem perceber que toda ação pedagógica não apenas é permeada por suas concepções teóricas sobre como percebe a si e ao outro - e as revela -, mas também imprime suas marcas na forma como planeja e organiza seu trabalho.

Para discutir esta afirmação, recorremos a expressões, geralmente ditas e ouvidas em espaços escolares, que apontam para três grandes posições teóricas criticadas por Vigotski $(2001,2007)$, as quais, em voga em sua época, tratavam da relação entre aprendizado e desenvolvimento.

Nossa intenção, neste momento, é ilustrar como, ainda hoje, vestígios dessas concepções permeiam os modos como muitos educadores pensam e organizam sua prática. Em seguida, discutiremos o conceito de Zona de Desenvolvimento Proximal, apresentando-o como possibilidade de um "novo jeito" de conceber os processos de aprendizagem e desenvolvimento, a partir da teoria histórico-cultural.

A primeira posição teórica apresentada por Vigotski $(2001,2007)$ pode ser associada ao exemplo que expressa a existência de um período "ideal" para aprendizagem. Essa concepção revela-se na ideia de que o ensino ocorre de modo estrutural, e os estudantes necessitariam ter certos aprendizados já apropriados, para conseguirem se apropriar de outros, ou seja, "ele ainda não aprendeu a contar porque é muito imaturo para idade".

Em linhas gerais, esta expressão centra-se no pressuposto de que o desenvolvimento aconteceria de maneira isolada ao aprendizado, uma vez que este ocorreria a partir do momento em que o desenvolvimento atingisse certa etapa de maturação, e, portanto, existiria um momento apropriado para 
aprendizagem, ou seja, um momento no qual, biologicamente, os sujeitos estariam aptos para compreender este ou aquele conteúdo.

Vigotski (2007, p. 88) aponta que, para os estudiosos que assumem esta posição, "o desenvolvimento é sempre um pré-requisito para o aprendizado e que, se as funções mentais de uma criança [...] não amadurecerem a ponto dela ser capaz de aprender um assunto particular, então nenhuma outra instrução lhe será útil”. Neste caso, o desenvolvimento biológico é entendido como condição primária e essencial para que o estudante aprenda os conceitos ensinados pelo professor.

Para Vigotski (2007), isso representa um equívoco, pois, assim como o desenvolvimento não se subordina apenas às leis biológicas, tampouco se revela de modo proporcionalmente regular e crescente, de modo a formar estruturas estáticas e imutáveis ao longo do processo de aprendizagem.

Essa mesma premissa, que trata o desenvolvimento como algo regular e crescente, também pode ser percebida na organização dos principais materiais presentes na escola, como o livro didático, as apostilas e as sequências didáticas que, além de assumirem o papel de reguladores daquilo que será ensinado, fazem do professor e dos objetivos do ensino reféns de uma estrutura gradual e progressiva que, ao apresentarem pseudoconceitos, segundo Catanante (2013), partem do pressuposto de que a cultura construída historicamente necessita ser distribuída de modo "ideal” para ser compreendida pelo estudante na faixa etária em que se encontra.

A segunda posição teórica, diferentemente da anterior, defende que o estudante necessita ter certas funções amadurecidas como pré-requisito para aprender e revela-se na comum expressão que associa aprendizagem e desenvolvimento como processos equivalentes: "aprendizagem é desenvolvimento".

De acordo com Vigotski (2007), os teóricos que adotam tal teoria equivocam-se, ao defender que o processo de desenvolvimento se subordina à substituição de respostas inatas por outras mais complexas, mediante o acumulado de conteúdos, hábitos de conduta e comportamentos aprendidos ao longo da escolarização. E Vigotski (2010, p. 484) explica por quê: "aprendizagem não é desenvolvimento, mas corretamente organizada, conduz 0 desenvolvimento mental da criança”. 
Portanto, nossa análise nos permite dizer que, assim como os teóricos que a defendem, os professores que fazem uso desse tipo de expressão consideram que aprendizagem e desenvolvimento ocorrem de modo simultâneo, a partir de um acumulado de conhecimentos adquiridos ao longo do período de escolarização que, não necessariamente, promovem a transformação do próprio sujeito. Em outras palavras, a atividade pedagógica que considera aprendizagem e desenvolvimento como sinônimos para o mesmo processo não compreende que a aprendizagem deve favorecer a produção de novas capacidades intelectuais, e não apenas um aumento quantitativo de informações dominadas pela criança que "não produzirá nada qualitativamente novo" (DUARTE, 2001, p. 98).

Por fim, a terceira posição, de acordo com Vigotski (2010), refere-se ao aprendizado como um "andaime", em que não se chega à aprendizagem de um conceito, sem antes, necessariamente, ter "conquistado" a aprendizagem de outro.

Com efeito, compreendemos que expressões como "levantamento de conhecimentos prévios" marcam a organização de um ensino que, em seu cerne, fundamenta-se na concepção da subordinação da aprendizagem de um conceito a outro, como se, para aprender sobre um conceito, fosse necessário ao estudante possuir conhecimentos prévios sobre ele. O que está por trás dessa concepção é o sentido de condição, em que a aprendizagem de um novo conceito está condicionada a aprendizagens anteriores.

Vigotski (2010) explica que, a fim de superar as concepções anteriores, os teóricos que defendem essa posição apontam que o desenvolvimento e a aprendizagem se fundamentam em processos inteiramente diferentes entre si, mas relacionados, em que o desenvolvimento sempre representaria um elemento maior que o próprio aprendizado.

A esse respeito, opondo-se a essas três posições teóricas, o autor explica a relação entre aprendizagem e desenvolvimento como elemento decorrente da relação ensino-aprendizagem e apresenta, para análise desse fenômeno, o conceito de zona de desenvolvimento proximal, que se constrói na relação entre os sujeitos e os parceiros mais experientes. Esse conceito abre caminhos para analisar as relações que envolvem os processos de ensino e aprendizagem ordenados por concepções vinculadas às posições teóricas criticadas por 
Vigotski, e que, comumente, transparecem nas falas de muitos atores do cenário educativo.

Para nós, a superação desse limite se objetiva à medida que compreendemos a necessidade da avaliação e a consideramos como um instrumento simbólico do pensamento a favor do desenvolvimento, representando uma ação intrínseca à atividade humana, "transformando a forma e o conteúdo do seu pensamento" (ROSA; MORAES; CEDRO, 2016, p. 77), ao passo que amplia e potencializa o desenvolvimento dos sujeitos.

Desse modo, a avaliação, intrínseco à atividade pedagógica, revela-se em um processo dialético que possibilita o surgimento de novas formações intrapsíquicas, através do qual há uma movimentação ininterrupta, marcada por ritmos irregulares e não lineares, como o desenho infantil de uma linha em espiral, horizontal e irregular que, em seu traçado, apresenta marcas de progressos e retrocessos, como da criança pequena que ainda não domina a escrita formal, mas possui, em seu interior, disposição para tal.

A Figura 1, em analogia com a nossa compreensão, busca ilustrar 0 processo dialético ao qual nos referimos:

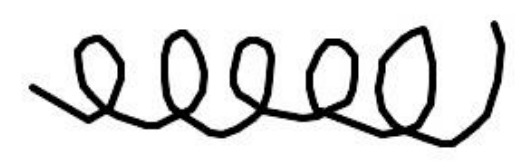

Figura 1. Representação da analogia entre o desenho infantil de linha em espiral (apresentando progressos e retrocessos de quem ainda não possui destreza motora para realização de traçado) e o movimento entre os níveis de desenvolvimento. Elaborado pela autora.

É importante destacarmos que a avaliação, como um movimento dialético contínuo, relaciona-se, de maneira indissociável, ao conceito de zonas de desenvolvimento proximal. Mas, a fim de fazermos dessa relação um objeto de análise, vamos estudá-la em etapas, como o próprio Vigotski (2001) apresenta: a primeira diz respeito ao Nível de Desenvolvimento Atual, que, de modo geral, representa aquilo que a criança consegue fazer por si mesma, associando-se às tarefas que ela tem condições de realizar sem a assistência do outro e, por isso, manifesta-se como um aprendizado já internalizado. 
Ao explicá-la, Vigotski (2007) apresenta uma analogia, mostrando que este nível, ao ser definido por funções que se estabilizaram internamente, corresponde aos "brotos ou flores do desenvolvimento, em vez de frutos do desenvolvimento" (VIGOTSKI, 2007, p. 98, grifos do autor), pois aquilo que se encontra amadurecido no nível de desenvolvimento atual não equivale ao "ponto final da aprendizagem", mas a algo que está apenas começando.

Outra etapa trata do Nível de Desenvolvimento Potencial, que é definido pelo autor como aquilo que o estudante virá a realizar, mediante a concretização de ações intencionalmente planejadas pelo professor, pois, como explica Moura et al. (2010), mesmo que não exista uma correspondência direta entre ensino e desenvolvimento, as vivências construídas na relação ensino-aprendizagem permitirão que o conhecimento humano, transformado em objeto de ensino, seja objetivado pelo estudante e se torne mobilizador das possibilidades de seu desenvolvimento.

Em síntese, essas etapas de desenvolvimento indicam os níveis que se encontram entre aquilo que o estudante realiza sem auxílio direto de parceiros mais experientes e o ponto aonde se pretende que ele chegue.

Nessa direção, o percurso entre esses dois pontos apenas se torna possível mediante a unidade existente entre eles, como podemos observar na Figura 2, em que os polos se ligam pelo processo dialético a que nos referimos anteriormente:

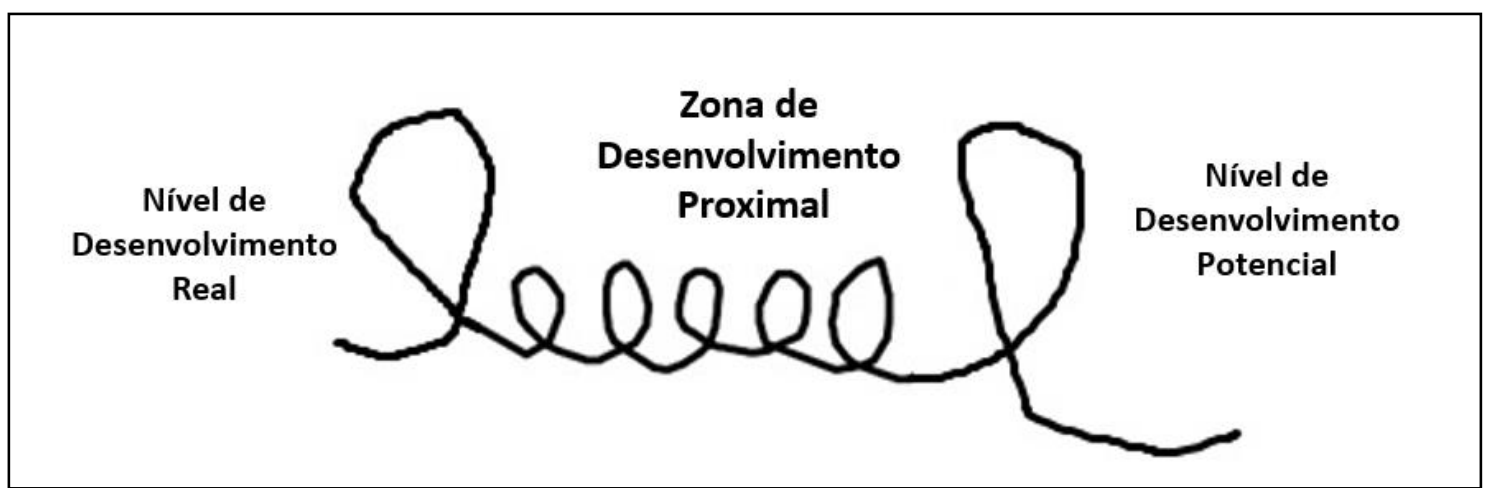

Figura 2. Movimento dialético e prospectivo de desenvolvimento, baseado no conceito de Zona de Desenvolvimento Proximal (VIGOSTSKI, 2001). Ilustração elaborada pela autora, inspirada em Araujo (2003).

Esta ligação, significada inicialmente como processo dialético, configurase como elemento central desta abordagem e representa um dos conceitos mais 
difundidos de Vigotski: o conceito de Zona de Desenvolvimento Proximal, ${ }^{2}$ que se refere à possibilidade de desenvolvimento a partir da mediação social, ou seja, da relação com parceiros mais experientes, em que se constroem vivências que criarão condições para a criança passar daquilo que sabe para aquilo que não sabe, pois "a criança orientada, ajudada e em colaboração sempre pode fazer mais e resolver tarefas mais difíceis do que quando sozinha" (VIGOTSKI, 2001, p. 328).

$\mathrm{Na}$ Zona de Desenvolvimento Proximal, a criança realiza uma tarefa por meio da imitação ou com auxílio de parceiros mais experientes, porque isto já faz parte da zona de suas próprias potencialidades intelectuais, pois a imitação ou a mediação não garantem a solução de toda e qualquer tarefa. Há "um certo limite, que é diferente para crianças diferentes" (VIGOTSKI, 2001, p. 329), de modo que, mesmo em colaboração, a criança irá resolver com mais facilidade apenas as tarefas mais próximas ao seu nível de desenvolvimento.

No contexto escolar, Duarte (2001) refere-se à importância da Zona de Desenvolvimento Proximal na relação ensino-aprendizagem. Assim afirma:

Se o conteúdo escolar estiver além dela, o ensino fracassará porque a criança é ainda incapaz de apropriar-se daquele conhecimento e das faculdades cognitivas a ele correspondentes. Se, no outro extremo, o conteúdo escolar se limitar a requerer da criança aquilo que já se formou em seu desenvolvimento intelectual, então o ensino torna-se inútil, desnecessário, pois a criança pode realizar sozinha a apropriação daquele conteúdo e tal apropriação não produzirá nenhuma nova capacidade intelectual nessa criança. (DUARTE, 2001, p. 98)

Nesse sentido, o ensino escolar que se organiza a partir de avaliações, cujo objetivo se limita a verificar a aprendizagem ou a qualidade do processo ocorrido (FREITAS, 2014), indicando "aprendizagens conquistadas", dificilmente

\footnotetext{
2 Prestes (2013), ao tratar da expressão em russo, Zona Blijaichego Razvitia, explica que a tradução mais adequada à gênese do conceito apresentado por Vigotski, seria zona de desenvolvimento iminente. "É importante esclarecer e registrar que a mudança proposta de proximal, próximo ou imediato para iminente, não é, como tem aparecido em algumas produções teóricas brasileiras mais recentes, apenas uma alteração de palavra, mas implica uma mudança importante para a compreensão do conceito que ainda hoje é alvo de debates e estudos no mundo inteiro. As palavras próximo, proximal ou imediato não transmitem a característica essencial do conceito que é a da possibilidade de desenvolvimento" (PRESTES, 2013, p.299). Entretanto, ao fazermos uso dos termos Proximal ou Iminente, o faremos em acordo com as bases teóricas utilizadas como referenciais para construção deste trabalho, tomando os cuidados necessários para que a amplitude do conceito não seja reduzida.
} 
proporcionará ao professor condições para que ele organize sua atividade a favor da apropriação do conhecimento produzido historicamente, pois, assim como Vigotski (2001, p. 334) afirma, defendemos que "o ensino seria totalmente desnecessário se pudesse utilizar apenas o que já está maduro no conhecimento".

Com efeito, apenas por meio de uma "nova" concepção de avaliação, em que, de instrumento de mensuração, ela passe a ser qualificada como ação mediadora, é que a função social da educação escolar será realizada, criando condições para que o estudante, na relação ensino-aprendizagem, ao se apropriar do conhecimento científico, perceba-se como herdeiro do conhecimento elaborado pelas gerações precedentes (RIGON; ASBAR; MORETTI, 2016); e para que o professor, ao planejar sua atividade, assuma não apenas uma responsabilidade que remete à transposição cultural de um conteúdo escolarizado, mas também o compromisso social de sua profissão, de favorecer "que as novas gerações 'tomem (cons)ciência' dos conhecimentos historicamente construídos pelos seres humanos" (ARAUJO, 2003, p. 32).

A seguir, ao abordarmos a questão da avaliação, analisaremos em que medida o instrumento habitualmente utilizado para medição da aprendizagem e/ou verificação da qualidade do processo ocorrido pode, na relação ensinoaprendizagem, constituir-se como componente intrínseco à ação humana e, assim, ser significado como unidade mediadora da atividade de ensino e atividade de aprendizagem, com vista à possibilidade de desenvolvimento no sentido próprio da palavra, apresentado por Vigotski (2017).

\subsection{Da relação entre o desenvolvimento humano e a avaliação}

A busca por "um jeito" de olhar a avaliação, assim como discutimos anteriormente, faz referência à necessidade de significá-la para além dos limites restritos a mensurar a capacidade de aprendizagem e verificar a qualidade do processo ocorrido, direcionando-nos para compreender que, como ação mediadora do desenvolvimento humano, objetivada pela vivência entre a criança e o adulto, a avaliação deve ser considerada como componente da atividade

pedagógica e, como elemento intrínseco à relação ensino-aprendizagem, tem o 
papel de auxiliar na organização do ensino, com vistas a mobilizar e impulsionar o surgimento do novo, do desenvolvimento humano.

Tratar da avaliação, portanto, representa "um jeito", uma possibilidade, uma perspectiva de transformar a organização escolar e a atividade docente que, grosso modo, comumente, partem do ensino que prioriza o treino de habilidades e competências, em detrimento daquele que parte do movimento histórico de produção dos conceitos, "sem levar em conta que o ensino deve fazer o desenvolvimento avançar" (VIGOTSKI, 2001, p.333).

Assim, deslocar a avaliação de seu papel de medidora ou verificadora para a função de unidade mediadora da relação ensino-aprendizagem, à luz da teoria histórico-cultural, implica em uma análise que transcenda as características impressas por um instrumento avaliativo organizado para controle quantitativo de proficiências, que "subestimam o estado do desenvolvimento como um jardineiro tolo: só pelos frutos já maduros" (VIGOTSKI, 2001, p.333), pois, ao passo que consideram apenas os processos já amadurecidos e internalizados, tomando a amostragem de respostas dadas pelo estudante como sinônimo da relação ensino-aprendizagem, acabam por levar em conta somente o "saber" explicitado por testes, o qual, não necessariamente, corresponde à aprendizagem que possibilita o desenvolvimento.

Nosso "jeito", entretanto, assim como temos afirmado, parte do princípio de avaliação como ação inerente à atividade humana, pois, como explica Moraes (2008, p. 18):

O homem, ao realizar uma ação, ele antes a idealiza. Neste processo ele avalia a importância e a possibilidade de execução, quais instrumentos serão utilizados para dar conta dos objetivos, isto é, para assegurar que sua atividade esteja adequada aos fins propostos, recorre à avaliação constante.

Nesse sentido, ao idealizar uma ação, qualquer que seja, à medida que o sujeito avalia a importância e as possibilidades de execução, antecipa empecilhos, criando estratégias e soluções e, após, ao passo que executa aquilo que antes estava em seu pensamento, coloca-se novamente a avaliar, não apenas para o ontem, analisando se suas ações o levaram a alcançar seus objetivos, mas para o amanhã, o que lhe permite planejar novas ações. Nesse 
ínterim, novas relações se formam e transformam as necessidades dos sujeitos, à medida que eles modificam o que está a sua volta.

Assim, o estudo da avaliação como unidade mediadora na relação ensinoaprendizagem, com vista às possibilidades de desenvolvimento humano, implica em uma análise que se coloca para além dos fenômenos observáveis por meio de testes que, ao orientar-se para o ontem, não leva em conta que os sujeitos podem passar do que sabem para o que não sabem, assim como "um jardineiro que, para definir o estado de todo o jardim, não pode resolver avaliá-lo apenas pelas macieiras que já amadureceram e deram fruto, mas deve considerar também as árvores em maturação" (VIGOTSKI, 2001, p. 333). O professor, do mesmo modo, ao avaliar, não deve considerar apenas as particularidades já aprendidas, mas aquelas que se encontram na zona de potencialidades dos estudantes, ou seja, na zona de desenvolvimento proximal.

Apoiamo-nos, portanto, na tese vigotskiana de que o homem, como ser social, se constitui pelo movimento de apropriação da cultura humana por meio da vivência mediatizada por outros sujeitos, partindo do social ao individual, de modo que, em sua mente, o planejamento de suas ações, desde então, é mediado constantemente por avaliações. Tal fundamentação nos permite compreender a relação ensino-aprendizagem também como uma ação social mediada por relações interpsíquicas (atividade coletiva), as quais se constituem em relações intrapsíquicas (atividade individual) que não ocorrem espontaneamente, mas derivam de situações planejadas intencionalmente para que a experiência humana possa ser vivenciada pelo estudante em situações de ensino e de aprendizagem. $E$ isso favorece que a atividade coletiva se transforme em atividade individual (MOURA et al., 2010).

Moura et al. (2010, p. 224), defendem ainda que "a avaliação constitui-se parte inerente do planejamento e da realização da atividade, tendo em vista que essa se concretiza no processo de análise e síntese na relação entre a atividade de ensino do professor e a atividade de aprendizagem do estudante".

Portanto, à medida que o professor organiza seu trabalho com vistas à apropriação da cultura humana, sua intencionalidade, elaborada inicialmente em sua imaginação, constitui-se em sua práxis pedagógica e, com a transformação dos sujeitos, transforma a realidade escolar, o que se reflete na relação ensinoaprendizagem (MOURA et al., 2010). 
Desse modo, o papel da educação escolar coloca-se como indispensável à transformação do sujeito, o que nos atribui a tarefa de significar a avaliação como ação mediadora, que, na acepção de Vigotski (2007, p.72), apresenta-se como "um condutor da influência humana sobre o objeto da atividade; ele é orientado externamente; deve necessariamente levar a mudanças nos objetos". Tal acepção indica para nós a necessidade de assumirmos que a avaliação da aprendizagem é, também, a avaliação do ensino e, nessa perspectiva, a avaliação torna-se uma "ação mediadora" na relação ensino-aprendizagem.

No próximo capítulo discutiremos os princípios norteadores do ensino brasileiro e analisaremos brevemente como o processo histórico de elaboração dos referenciais da educação influenciou a organização dos princípios da organização do ensino, bem como consolidou, na cultura escolar, características subjacentes à educação, voltadas apenas ao desenvolvimento de habilidades e competências a favor do mundo do trabalho e do convívio social.

Nesse sentido, discutiremos em que medida a avaliação, nesse modelo organizacional de ensino, pode superar seu papel de instrumento verificador, para configurar-se como ação intrínseca aos sujeitos e, por isso, mediadora da atividade de ensino e de aprendizagem, uma vez que a temos defendido como reguladora das possibilidades de desenvolvimento via organização do ensino escolar. 


\section{UM OLHAR PARA A BNCC E SUA RELAÇÃO COM O CURRÍCULO, AS PRÁTICAS E AS CONDUTAS ESCOLARES}

O desenvolvimento do ensino capaz de levar o sujeito a compreender e a utilizar uma informação escrita, a refletir e operar sobre ela, assim como desenvolver habilidades que Ihe permitam reconhecer, desde simples elementos numéricos até operações que Ihe proporcionem condições de atuação no mundo do trabalho e no convívio social, corresponde aos princípios expressos pela Base Nacional Comum Curricular (BRASIL, 2017), ao se referir sobre o desenvolvimento de competências mobilizadoras de conhecimento como representação do papel social do ensino.

Nesse sentido, a escola, como discutimos anteriormente, mesmo representando um privilegiado espaço de apropriação do conhecimento (RIGON; ASBAR; MORETTI, 2016), ao longo dos anos organizou-se, de acordo com Freitas (2013), para atender os modos atuais que passaram a gerir a sociedade como um todo, influenciando desde nossas decisões e escolhas até os modos de convivência e relacionamento com os outros e com o meio, revelando-se sob a luz de princípios capitalistas, instaurados pela lógica do consumo, da competitividade, da padronização, da qualificação técnica e da busca por resultados que, no meio educacional, materializam-se na aplicação de políticas públicas de responsabilização por meio de avaliações classificadoras, ranqueadoras e excludentes, comumente utilizadas como instrumentos verificadores de aprendizagem ou da qualidade do processo ocorrido.

Todavia, não podemos negar os efeitos da implementação das diferentes políticas públicas ligadas à naturalização desta lógica, pois, atreladas a elas, propostas de democratização das condições de acesso e permanência modificaram importantes dados em relação à alfabetização do povo brasileiro. Com efeito, segundo o Relatório Indicador Nacional de Alfabetismo Funcional/ 2018 (INAF), realizado a partir da pesquisa conduzida pelo Instituto Paulo Montenegro, entre a população de 15 a 65 anos, houve uma queda representativa de 10 pontos no percentual de analfabetos, no período de 2001 a 2018, assim como destacamos no Gráfico 1: 


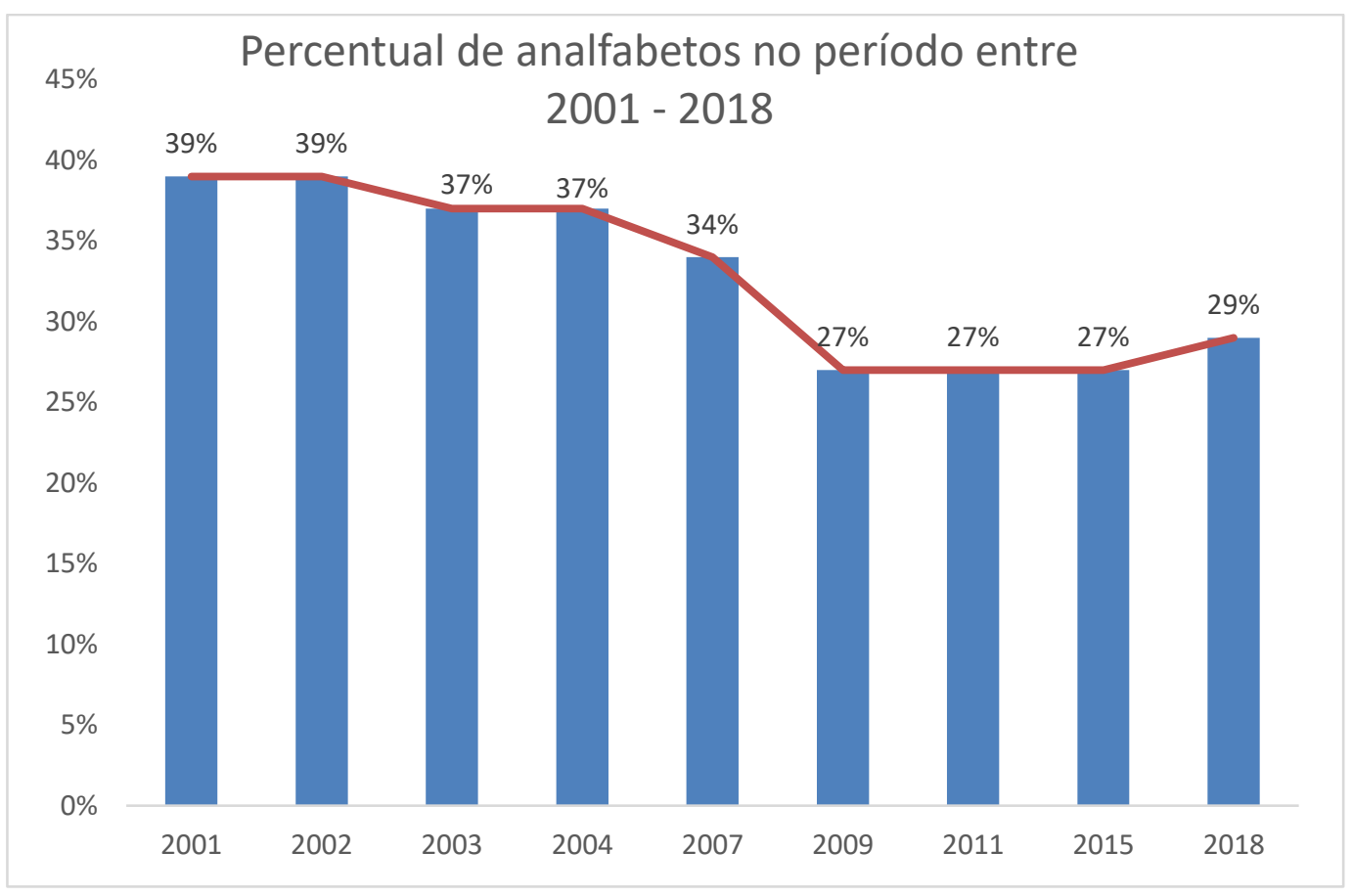

Gráfico 1. Percentual de analfabetos no período entre 2001 e 2018. Elaborado pela autora. Fonte: Relatório INAF (2018).

Nessa perspectiva, poderíamos inferir que a queda nos índices de analfabetismo é decorrente do aumento do número de pessoas nas escolas, uma vez que isso tem sido assegurado pelas diferentes políticas públicas educacionais que, voltadas às condições de acesso, ligam-se às condições de permanência dos estudantes em espaços formais de ensino, em todos os segmentos: creches, escolas de educação básica e universidades.

Entretanto, cabe questionarmos em que medida tais políticas, ao serem implementadas, têm possibilitado que em sala de aula ocorram situações desencadeadoras do desenvolvimento multilateral dos sujeitos (DAVIDOV, 2017; LEONTIEV, 2004), permitindo que, ao passo que superem a condição de analfabetos e sejam alfabetizados na "idade certa", possam se apropriar da herança cultural construída historicamente, ultrapassando as barreiras do ensino que se fundamenta na promoção de competências, principalmente voltadas ao mundo do trabalho e do convívio social, limitadas ao meio circundante, que, se por um lado proporcionam "conhecimentos e habilidades sem os quais é

\footnotetext{
${ }^{3}$ Cabe esclarecermos aqui que, ao tratarmos da expressão "idade certa", referimo-nos à idade prevista pela lei № 11.114/05, que regulamenta o ingresso da criança no ensino fundamental até a conclusão do ciclo de alfabetização que, para a Base Nacional Comum Curricular, corresponde, prioritariamente, aos dois primeiros anos do ensino fundamental.
} 
impossível obter uma profissão mais ou menos significativa na produção industrial e na vida social (saber escrever, contar, ler, ter ideias elementares sobre o meio circundante)" (DAVIDOV, 2017, p. 211-212), por outro lado, configuram-se como habilidades e conhecimentos que, por sua vez, não promovem o desenvolvimento dos nexos próprios do pensamento teórico que, para Davidov (1988), configura-se como um tipo específico de pensamento, diferente do pensamento empírico, construído pelo cotidiano na realização de atividades laborais. Apesar interdependentes, Franco (2015, p.23) explica que, para Davidov, o pensamento teórico "tem por finalidade reproduzir a essência do objeto estudado no decurso da formação das ações mentais que ocorre no processo intencional de um ensino para o desenvolvimento".

Para além da análise estatística, nossa discussão se coloca a refletir acerca das possibilidades de apropriação da cultura via educação, uma vez que esta se constitui na experiência social, em que a experiência da humanidade passa a ser também a experiência do sujeito, revelando-se em práticas e condutas mobilizadoras de possibilidades de humanização, lugar em que a avaliação, como ação inerente a esse processo, configura-se como mediadora da relação ensino-aprendizagem.

Nessa direção, após o estudo acerca da relação entre a criança e o adulto, as concepções de aprendizagem e desenvolvimento, e a mudança de ótica em relação à avaliação, neste capítulo, nosso objetivo centra-se em analisar os princípios intrínsecos à organização pedagógica, no que se refere à orientação de práticas e condutas, envolvidas por ações "eminentes de boas situações de aprendizagem" que, comumente, marcam a abertura e o fechamento do processo ensino-aprendizagem, valendo-nos do levantamento de conhecimentos prévios e da utilização de instrumentos avaliativos operacionalizados, com objetivo de verificar, não as possibilidades de desenvolvimento, mas a apropriação de competências essenciais para "resolver demandas complexas da vida cotidiana, pleno exercício da cidadania e do mundo do trabalho" (BRASIL, 2017, p. 8).

Para tal, organizaremos o capítulo em três subitens: iniciaremos com um breve levantamento histórico, em que destacaremos os princípios subjacentes a alguns referenciais da educação brasileira elaborados após a Constituição de 1988, citaremos a influência da Declaração Universal dos Direitos Humanos em 
relação à promoção de meios de "acesso" à educação, discutiremos a relação entre a função social da escola, como instituição representante do ensino formal, e o conceito atribuído à expressão "universalização do ensino", que se faz presente na maioria dos documentos analisados.

Em seguida, passaremos a discutir a relação entre os elementos que compõem a organização do ensino, mediante a função social do ensino no processo de humanização. Para essa análise, nos fundamentaremos nos princípios da teoria histórico-cultural, discutindo também a relação entre esse posicionamento teórico e nosso objeto, uma vez que a avaliação, como componente intrínseco à organização do ensino, comumente é assumida como instrumento medidor da aprendizagem.

Por último, além do aporte teórico, analisaremos os princípios pedagógicos de um exemplo de sequência didática que, como representante de uma "boa situação de aprendizagem", é marcado por avaliações "iniciais e finais" que, por sua vez, assumem o papel de indicadoras das conquistas dos estudantes, em resposta às habilidades presentes na Base, para a organização do trabalho docente.

As análises de Davidov acerca dos princípios da escola tradicional, alinhados à tese vigotskiana de desenvolvimento, além do aporte de outros autores que compartilham dos princípios da teoria histórico-cultural, fundamentarão nossa discussão diante das possibilidades de uma organização escolar que possibilite aos sujeitos condições para que a avaliação do ensino, em sua totalidade, permita não apenas o "direito à aprendizagem", mas, sobretudo, o direito à educação.

\subsection{Para além da declaração: do direito a aprendizagem à luta pela universalização do ensino}

Toda pessoa tem direito à educação (DECLARAÇÃO UNIVERSAL DOS DIREITOS HUMANOS, 1948, Art. 26).

Cury (2002) aponta que desde a Declaração Universal dos Direitos Humanos (1948) há um movimento internacional pela busca da consolidação dos direitos fundamentais da pessoa, em que a educação se configura em instrumento de redução das desigualdades e discriminações dos povos, uma vez 
que sua universalização, ainda hoje, representa um importante passo na busca pela "garantia de um futuro melhor para todos" (CURY, 2002, p. 246).

Nessa direção, o autor também afirma que a Declaração de Jomtien, também conhecida como Declaração Mundial de Educação para Todos (1990), representou um importante acontecimento no que diz respeito à educação, pois em linhas gerais, ao firmar compromissos mundiais, pretendia garantir a todas as pessoas o acesso aos conhecimentos considerados indispensáveis a uma vida digna, o que, para o Brasil, significou a elaboração do Plano Decenal de Educação para Todos, que, em sintonia com a Constituição de 1988, pleiteava diminuir as desigualdades, equalizar as oportunidades de acesso à educação e favorecer o desenvolvimento da pessoa, preparando-a para o exercício da cidadania, ao passo que a qualificava para o trabalho. Exemplo disto pode ser observado no texto do próprio documento, que assim afirma:

Cabe ao Brasil a responsabilidade de assegurar à sua população o direito à educação - compromisso, aliás, reafirmado e ampliado em sua Constituição de 1988 - e, dessa forma colaborar para os esforços mundiais na luta pela universalização da educação básica. [...] $A$ retomada do compromisso de Jomtien, de elaborar um plano para concretizar suas metas, encontra condições amplamente favoráveis. Multiplicaram-se, pelo País, ações de caráter inovador visando universalizar com qualidade o ensino básico. Além disso, há um renovado reconhecimento, por vários segmentos sociais, da importância da educação básica para a formação do cidadão e para a retomada do desenvolvimento nacional sob novos valores e perspectivas. (BRASIL, 1993, p. 11)

Cury (2011) destaca também que o Plano Decenal de Educação para Todos, juntamente com outros documentos que garantiram a participação do Brasil em encontros internacionais, constituiu-se como importante subsídio para a elaboração da versão preliminar do Plano Nacional de Educação (PNE) que, após consulta pública e votação, entrou em vigor como documento oficial em 1996. Tal documento, reelaborado a cada dez anos, atualmente considera diretrizes, estratégias e metas, contribuindo para que estados e municípios, de acordo com suas demandas e necessidades, elaborem planos específicos para alfabetizar todas as crianças, no máximo, até o final do terceiro ano do ensino fundamental e fomentar a qualidade da educação básica em todas as etapas e 
modalidades, com melhoria do fluxo escolar e da aprendizagem, de modo a atingir as médias nacionais para o ldeb, entre outras (BRASIL, 2014).

Em 1997, com a elaboração dos Parâmetros Curriculares Nacionais para o Ensino Fundamental (PCN), o Brasil passou a ter o primeiro documento capaz de indicar o que deveria ser assegurado aos estudantes em território nacional, explicitando, logo em suas primeiras linhas, que esse seria "um referencial de qualidade para a educação no Ensino Fundamental em todo o País" (BRASIL, 1997, p.13), pois, além de uma análise das características e do papel de cada uma das áreas do currículo, trataria da relação entre o estudante e o professor, indicaria caminhos e objetivos gerais para o ensino fundamental, bem como aspectos ligados ao ensino, aprendizagem e currículo, que em Matemática, por exemplo, estaria organizado a partir de blocos de conteúdos, com critérios de avaliação e orientações didáticas.

Mais tarde, como resultado da busca de sistemas educativos que pudessem contribuir para o pleno desenvolvimento de crianças, adolescentes, jovens e de adultos que não tiveram oportunidade de frequentar a escola regular em idade adequada, em 2013 foram lançadas as Diretrizes Curriculares Nacionais, com objetivo de oferecer formação de qualidade correspondente à idade e ao nível de aprendizagem dos estudantes, buscando "potencializar o ser humano como cidadão pleno, de tal modo que este se torne apto para viver e conviver em determinado ambiente, em sua dimensão planetária" (BRASIL, 2013c, p. 16).

Em 2017, após duas versões preliminares, entrou em vigor o texto final da Base Nacional Comum Curricular (BNCC), que, desde então, intitula-se como documento plural e contemporâneo e estabelece um conjunto de aprendizagens essenciais e indispensáveis a todos os estudantes. Esse documento se assume como o início de uma nova etapa da educação brasileira, pois, como afirma, alinha-se "aos melhores e mais qualificados sistemas educacionais do mundo" (BRASIL, 2017, p. 5), destacando que:

Com ela [a Base], redes de ensino e instituições escolares públicas e particulares passam a ter uma referência nacional obrigatória para a elaboração ou adequação de seus currículos e propostas pedagógicas. Essa referência é o ponto ao qual se quer chegar em cada etapa da Educação Básica, enquanto os currículos traçam o caminho até lá (BRASIL, 2017, p. 5, grifo nosso). 
Espera-se que a BNCC ajude a superar a fragmentação das políticas educacionais, enseje o fortalecimento do regime de colaboração entre as três esferas de governo e seja balizadora da qualidade da educação. Assim, para além da garantia de acesso e permanência na escola, é necessário que sistemas, redes e escolas garantam um patamar comum de aprendizagens a todos os estudantes, tarefa para a qual a BNCC é instrumento fundamental. (BRASIL, 2017, p. 8, grifo nosso)

Entretanto, apesar de o documento assumir-se como marco inicial de "uma nova era para educação brasileira" (BRASIL, 2017, p. 5), nossa análise comparativa entre esse referencial e os documentos, citados por nós, que o antecederam, revela, por um lado, a permanência de concepções que almejam a ascensão das camadas populares via formação cidadã e qualificação para o trabalho e, por outro, deixa ver, assim como explica Freitas (2014), a equalização da qualidade da educação ao sistemático controle de índices de desempenho que, na sociedade atual, passaram a ser aceitos como parâmetros correspondentes ao que pode ser considerado como resultado de uma "boa educação". Porém eles, sobretudo, não garantem aos sujeitos envolvidos nessa relação as reais possibilidades de desenvolver o pensamento teórico, pois, ao se referirem apenas às demandas da vida cotidiana, apresentam conceitos abreviados, moldados e simplificados (FREITAS, 2014).

Ao tratar destes instrumentos que possuem em seu eixo norteador 0 desenvolvimento de competências, o autor explica que o "saber fazer", associado à educação e medido por avaliações, revela-se por meio de uma "matriz formativa" que busca orientar a organização do trabalho pedagógico e a escolha daquilo que será contemplado pelos "direitos de aprendizagem".

Esses "direitos", que pretendem controlar não apenas os objetivos do ensino, mas também o papel social da escola, estão associados, de acordo com Freitas (2014), ao desenvolvimento de um conjunto de "conhecimentos, habilidades, atitudes e valores" (BRASIL, 2017, p.13), que, além de indicarem a preservação do conhecimento empírico (DAVIDOV, 2017), apontam para um estreito alinhamento entre a organização escolar brasileira e os interesses de um "grupo de políticos, mídia, empresários, empresas educacionais, institutos e fundações privadas e pesquisadores" (FREITAS, 2014, p. 1110). Esses protagonistas, ao "definirem" os objetivos do ensino, relacionando-os à concepção do mercado financeiro, de acordo com o autor, partem da iniciativa 
privada como uma proposta mais "assertiva para consertar a educação" do que as propostas feitas pelos educadores. Com isso pretendem:

\begin{abstract}
Entre outros aspectos, abrir o campo educacional para "empresas educacionais confiáveis" do mercado de consultoria, materiais didáticos, avaliação, venda de tecnologia, organização de big data entre outras, que operam na difusão de métodos tecnicistas e introduzem nas redes e escolas processos de gestão verticalizados que permitem elevar o grau de controle sobre os profissionais da educação, a título de garantir a obtenção de metas e índices nas avaliações externas, definindo os objetivos, a avaliação, a forma e o conteúdo da escola. (FREITAS, 2014, p. 1093)
\end{abstract}

Esse estreitamento entre os objetivos velados pela BNCC, bem como pelos referenciais precedentes a ela e pelos interesses de um grupo social, há muito tem sido objeto de análise para pesquisadores.

Exemplo disso podemos encontrar em Altmann (2002), que, há quase vinte anos, já colocava em discussão as estratégias recomendadas pelos economistas do Banco Mundial (Banco Internacional para a Reconstrução e Desenvolvimento - BIRD) aos países em desenvolvimento que, visando a ações para enfrentar a luta contra a pobreza, a partir da década de 90 desencadearam uma série de medidas estruturais para a organização educacional.

Tais medidas, compreendidas como indispensáveis à qualidade de vida, em que os serviços básicos, como saúde elementar, planejamento familiar e nutrição passaram a modelar a elaboração de políticas públicas de acesso e permanência, como, por exemplo, o oferecimento de auxílios às famílias com baixa renda, para que mantivessem crianças em idade escolar matriculadas em instituições de ensino; o aumento do tempo de instrução, considerando obrigatório o ensino fundamental e após o ensino médio; a oferta gratuita do livro didático; o investimento na formação técnica de professores em serviço; e a centralização de padrões que facilitassem o "monitoramento e a qualidade da educação", baseando-se em resultados verificáveis a partir do desempenho escolar (ALTMANN, 2002).

Nesse sentido, o "direito à aprendizagem" mobilizado por políticas que permitiram maior controle do processo educacional e da padronização dos conteúdos ensinados nas escolas, desencadearam uma conexão entre os instrumentos reguladores - as avaliações - e o interior das escolas, de modo que o direito de aprender, quando bem-sucedido, passou a ser compreendido 
como o "direito de acessar o conhecimento básico das matrizes de referências de avaliação" (FREITAS, 2014, p. 1100), suscitando outros tipos de exclusão não previstas pelo "direito" explicitado em forma de lei (CURY, 2002), como aquela que, em detrimento da falta de avanço, exclui dos esforços pedagógicos estudantes que não aprendem (DUBET, 2003).

Cury (2002) explica ainda que apenas a garantia de um direito previsto em lei não é suficiente para superar as múltiplas formas do não acesso em uma sociedade como a brasileira, cheia de contrastes derivados da colonização, em que é indiscutível que a pirâmide educacional não se assemelhe à pirâmide social, que tem sua base formada por dois grandes grupos, um dos quais é composto por pessoas com poucos anos de escolarização e outro, por pessoas que não tiveram qualquer tipo de acesso à escola, o que justifica, no caso brasileiro, o alto índice de analfabetos.

Todavia, Cury (2002, p. 259) ressalta que, para que esse direito não seja esquecido nem mesmo por países com fortes tradições elitistas, em que poucos têm acessos aos bens sociais, é imprescindível existirem leis que busquem assegurá-lo e garanti-lo, pois "declarar e assegurar é mais do que uma proclamação solene. Declarar é retirar do esquecimento e proclamar aos que não sabem ou esqueceram, que eles continuam a ser portadores de um direito importante".

Nessa direção, o autor destaca que o direito à aprendizagem corresponde à apropriação da herança cultural como possibilidade de desenvolvimento cidadão, uma vez que a capacidade de se apossar de padrões cognitivos e formativos possibilita maiores condições de participação e transformação, ou seja:

Ter o domínio de conhecimentos sistemáticos é também um patamar sine qua non a fim de poder alargar o campo e o horizonte desses e de novos conhecimentos. $O$ acesso à educação é também um meio de abertura que dá ao indivíduo uma chave de autoconstrução e de se reconhecer como capaz de opções. O direito à educação, nesta medida, é uma oportunidade de crescimento cidadão, um caminho de opções diferenciadas e uma chave de crescente estima de si. (CURY, 2002, p. 260)

Concordamos com o autor no que diz respeito à apropriação da herança cultural como direito inerente ao sujeito para que este possa desenvolver-se. 
Entretanto, alinhando-nos aos princípios da teoria histórico-cultural, consideramos que, mais do que uma oportunidade de crescimento cidadão, o direito à aprendizagem deve ser convertido em direito à educação, configurandose na universalização do ensino, como caminho pelo qual professor e estudante podem estabelecer inter-relações entre o interno e o externo, o que permite aos sujeitos condições para "modificar as formas de interação com a realidade que os cerca [...] transformando a forma e o conteúdo do seu pensamento" (ROSA; MORAES; CEDRO, 2016), ao passo que o direito, outrora estático, torna-se vivo e revela-se em uma autêntica atividade - de ensino e de aprendizagem - que possibilita a construção do pensamento teórico, "no qual se passa da percepção sensível do objeto à generalização" (ARAUJO; MORAES, 2017).

Nessa relação, para a teoria histórico-cultural, a universalização do ensino, entendida como sinônimo de possibilidade de apropriação da cultura humana, representa a transformação dos indivíduos no decorrer desse processo, "que não se encerra na vida adulta, ele se estende em todas as idades por ser um processo de natureza social" (BRITO, 2017, p. 56) que ocorre como via para o desenvolvimento humano, a partir da construção do pensamento teórico, em que o acumulado de competências medidas por instrumentos avaliativos que formam o cidadão e o qualificam para o trabalho não é suficiente para colocar o sujeito em atividade, de modo a permitir que ele venha a se apropriar das riquezas deste mundo.

Apenas com sua participação na produção e nas diversas formas de atividade social, por meio de vivências intencionalmente organizadas, é que se pode desenvolver nos sujeitos aptidões especificamente humanas (LEONTIEV, 2004), ou seja, "o homem é um ser social, que, fora da interação social, ele nunca desenvolverá em si aquelas qualidades, aquelas propriedades que têm sido desenvolvidas como resultado da evolução histórica de toda humanidade" (VIGOTSKI, 2017, p. 35).

Assim, compreendemos a universalização do ensino, para além da garantia de acesso e de construção de competências: configura-se como caminho para o desenvolvimento humano e ultrapassa os objetivos declarados pelos documentos referenciais da educação brasileira e dos padrões impostos pelos níveis de proficiência expressos por instrumentos avaliativos, uma vez que 
a possibilidade de humanização do sujeito, elemento básico do papel social da escola, compõe a essência do direito à educação.

Não coube ao nosso estudo uma análise aprofundada sobre cada um dos documentos citados na linha histórica que construímos na introdução deste texto, mas, ao analisá-los, buscamos discutir como o movimento histórico de criação desses referenciais contribuiu para organização do ensino e legitimou, sob a égide do direito à aprendizagem, o uso de instrumentos avaliativos que, na cultura escolar, constituem-se como explicitadores de "uma boa educação".

Nosso questionamento busca compreender e analisar em que medida os objetivos voltados à formação cidadã e à capacitação para o trabalho, explicitados em cada documento, têm proporcionado a real aproximação entre a prática efetuada no chão da escola e o desenvolvimento humano, no que diz respeito às possibilidades de desenvolvimento tanto do estudante como do professor, pois, como um ato de amor e de coragem, não podemos temer o debate, nem a análise da atual realidade (FREIRE, 2005).

Assim, entendemos que a universalização do ensino, da maneira como é compreendida por esses referenciais, não cria as verdadeiras possibilidades para o desenvolvimento, no sentido próprio da palavra (VIGOTSKI, 2001), pois, ao tratarem do acesso, tais documentos respondem às exigências do mercado e propõem o desenvolvimento de competências que colocam sobre os sujeitos a responsabilidade de acessá-las ou não, independentemente de outros direitos que, em sua maioria, encontram-se indisponíveis a grande parte da população e influem significativamente nas formas de acesso à educação (FREITAS, 2014).

A seguir, trataremos de alguns elementos selecionados para estudo do nosso objeto, como o conceito de formação docente; a identificação do papel social dos sujeitos que participam da relação professor-estudante e o papel que a avaliação exerce, ao mediar a relação entre esses elementos, buscando analisar os modos como se articulam mediante a função social do ensino para a humanidade.

\subsection{A relação entre os elementos que compõem o ensino}

Não há nada que contradiga e comprometa a emersão popular do que uma educação que não jogue o educando as experiências do debate e da análise dos problemas e que não the propicie condições de 
verdadeira participação. Vale dizer, uma educação que longe de se identificar com o novo clima para ajudar o esforço da democratização, intensifique a nossa experiência democrática, alimentando-a.

(FREIRE, 2005, p. 101)

A dinâmica de estudo que temos realizado para análise dos referenciais que têm orientado a educação brasileira nas últimas décadas, assim como explicitado por Marques (1992), aponta que, da elaboração do projeto até sua aprovação em forma de lei, os documentos passam por um longo processo que envolve desde o respaldo teórico de diferentes movimentos relacionados à educação, com intuito de que o documento não manifeste apenas a visão de um único grupo, como, por exemplo, a Declaração Universal dos Direitos Humanos (1948), a Constituição Federativa Brasileira (1988) ou a Declaração de Jomtien (1990), passam também, por situações de consulta e debate público para que, apenas após esse caminho, chegue à sua etapa final, a votação no Congresso Nacional.

Todavia, mesmo com a existência desse movimento, há "a brutal separação entre os que pensam e decidem sobre as políticas da educação e os que as executam no dia-a-dia, condenados a práticas servis e mecânicas" (MARQUES, 1992, p.43), revelando o grande distanciamento entre o processo de elaboração e sua apropriação, de modo que o "como", o "porque" e o "para quê", ao serem apresentados em sua versão final, infundem o afastamento docente e desencadeiam a "desagregação e a desarticulação no interior da profissão" (MARQUES, 1992, p.43).

Assim, não apenas o estudante é "formado" com essa concepção, mas também o professor que, como afirma a BNCC (BRASIL, 2017), configura-se como importante articulador do efetivo cumprimento dos referenciais e, juntamente com as instituições escolares e as redes de ensino, como protagonista das transformações, recebe formações voltadas tanto à aplicação de "boas técnicas pedagógicas" quanto ao uso de tecnologias facilitadoras do "fazer docente". É isso que Araujo (2003) discute como reflexo de uma formação associada à concepção empírica do "saber fazer", que suscita a responsabilização dos profissionais da classe, pois este modelo relaciona diretamente a falta de resultados desejáveis à precarização da formação docente, seja em esfera inicial ou continuada, desconsiderando os diferentes 
aspectos que envolvem a(s) desigualdade(s) que estas políticas "buscam" equalizar.

Exemplo disso podemos observar em importantes documentos elaborados a partir da década de 90, que alteraram significativamente a educação brasileira, primeiro por estarem em consonância com a nova Constituição (1988), que, segundo Militão, Militão e Perboni (2011), representava um grande avanço para o País, por fixar um plano nacional de educação que garantisse a continuidade de políticas educacionais, quebrando 0 ciclo de descontinuidade que perdurou por mais de cinco décadas, desde sua primeira menção na Constituição de 1934; segundo, por alinhar-se aos movimentos mundiais que objetivavam a expansão do ensino e passaram a orientar o setor, até então abandonado; e terceiro, por responsabilizar os professores e suas formações pela ineficiência do ensino e subtrair de seus textos o compromisso dos poderes públicos com os problemas educacionais.

Nesse sentido, o Plano Decenal de Educação para Todos, a exemplo do que Militão, Militão e Perboni (2011) explicam, apesar de apresentar argumentos voltados à precarização da carreira docente, pautando-se na comparação entre o salário deste e de outros profissionais com os mesmos anos de estudo, explicitava, em seu texto, que o comprometimento da qualidade do desempenho dos estudantes justificava-se pelo esgotamento dos sistemas de formação inicial, pela inexistência de formação continuada dos professores, pela precariedade das práticas de seleção e admissão, pelo baixo grau de escolaridade, principalmente dos professores dos primeiros anos do ensino fundamental e em regiões mais pobres. Alia-se a isso a incapacidade de escolha de material de apoio, como no caso da política do livro didático que, segundo o documento, foi "abalada" pela insuficiente habilitação docente para avaliar e selecionar os materiais de acordo com suas necessidades (BRASIL, 1993).

Já nos Parâmetros Curriculares Nacionais, no componente curricular de Matemática, ao tratarem dos problemas do ensino, o referencial enfatiza que parte deles relacionava-se à qualidade insatisfatória da formação do magistério, que impedia que propostas "inovadoras" provocassem as mudanças esperadas, uma vez que os professores, por não compreenderem os problemas que motivavam as reformas, utilizavam concepções pedagógicas inadequadas ou 0 faziam de modo superficial, o que, em consequência, acarretava "muitos 
equívocos e distorções em relação aos fundamentos norteadores e ideias básicas que aparecem em diferentes propostas" (BRASIL, 1997, p. 22).

Tais argumentos abriram espaço para que, nos documentos subsequentes (Diretrizes Curriculares Nacionais e Base Nacional Comum Curricular), a temática das "competências" fosse legitimada e incorporada à sociedade, em um movimento acrítico, desde a infância, via formação de professores, pois o desenvolvimento de competências exige dos indivíduos um conjunto de habilidades para lidar com técnicas e instrumentos que, do campo da empregabilidade, passaram a ser aplicáveis ao campo do ensino (FREITAS, 2002), em consonância com o objetivo de formação e qualificação para o trabalho presente em todos os documentos desde a Constituição de 1988.

Desse modo, a lógica da competência, incorporada à área da educação, como explica Freitas (2002), dá ênfase à individualização deslocando o problema da esfera social para individual, por delegar aos professores responsabilidade pela própria formação e aprimoramento profissional, uma vez que cabe a ele identificar suas necessidades e empreender o esforço necessário a fim de supri-las; instigar práticas que elevam a avaliação, em seu uso instrumental, ao patamar mais alto da relação ensino-aprendizagem, pois esta passa a configurar-se como principal instrumento capaz de medir e apontar não apenas para o professor, mas para os estudantes, a sociedade e os poderes públicos - a relação entre um acumulado de respostas que se configuram, equivocadamente, como aprendizagem, ideia esta "que está posta pelas políticas públicas em vários países, e tem suas origens nas orientações do Banco Mundial visando à implementação da reforma educativa" (FREITAS, 2002, p. 157).

Freitas (2002, p. 157, p. 158) explica ainda que

uma primeira dimensão importante de ser destacada em relação à avaliação das competências é a dimensão da "certificação". Nessa direção, o documento introduz modificações importantes na maneira de conceber a formação e a profissionalização do magistério, entre as quais se destaca a proposta de organização de um sistema federativo de certificação de competência dos professores de educação básica.

$[\ldots]$

Esta iniciativa vai na direção de atender às necessidades postas pelo modelo de competências de submeter os trabalhadores/professores a uma validação permanente, como nos diz Ramos (2001), dando 
constantemente provas de sua adequação às necessidades do trabalho pedagógico. Nas atuais condições do exercício do magistério, - processo de certificação de competências contribuirá para aprofundar o quadro perverso caracterizado pela ausência de políticas de valorização e de formação continuada, pelas péssimas condições de funcionamento da grande maioria das escolas públicas e pela redução dos recursos públicos para o aprimoramento do processo educativo, trazendo como consequência a culpabilização e responsabilização dos professores pelo sucesso e/ou fracasso da escola e da educação pública.

Nesse sentido, a formação docente, qualificada por Araujo (2003) como aprendizagem, configura-se como um processo inerente aos seres vivos, que "ocorre sempre, ainda que de diferentes formas, com diferentes intencionalidades e com diferentes qualidades" (ARAUJO, 2003, p. 22). E nesses referenciais, que exercem direta influência na organização do ensino, tem sido colocada à margem, uma vez que o professor passa a configurar-se como articulador de técnicas voltadas às soluções práticas, pertinentes às ações rotineiras, que reduzem a atividade de ensino à sistematização procedimental de conteúdos. $\mathrm{E}$, em consequência, limitam a atividade de aprendizagem à assimilação de procedimentos que levam à resolução de problemas decorrentes, em sua maioria, da percepção dos sujeitos e situados no campo de vivência cotidiana.

Rosa, Moraes e Cedro (2016) explicam que este modo de organização é insuficiente para as apropriações referentes à formação do pensamento teórico que tem sua gênese na tese vigotskiana de que o conhecimento, mediado culturalmente, ocorre primeiro no social para depois ocorrer no individual. Ademais, implica a permanência das leis que se subordinam ao pensamento empírico, indispensáveis aos afazeres rotineiros, mas insuficientes à realização da função social da escola: a construção do pensamento teórico. Nas palavras de Davidov (1987, p. 144, grifo nosso), isso representa

\footnotetext{
um caráter classificador, catalisador, e assegura a orientação da pessoa ao sistema de conhecimentos já acumulados sobre as particularidades e os traços externos de objetos e fenômenos isolados da natureza e da sociedade. Tal orientação é indispensável para os afazeres cotidianos, durante o cumprimento de ações laborais rotineiras, porém é absolutamente insuficiente para assimilar 0 espírito autêntico da ciência contemporânea e os princípios de uma relação criativa, ativa e de profundo conteúdo em face da realidade.
} 
Assim, a formação docente, ao ser associada ao "fazer pedagógico", configura-se como modeladora não apenas dos objetivos do professor, mas também da função da escola, a qual passa a se orientar pelos resultados obtidos em avaliações, dando forma à organização do ensino e à percepção que o professor faz de si e do estudante na relação ensino-aprendizagem: reproduzse em vivências que, fortemente influenciadas pela lógica da individualização e da responsabilização, expressas pelo conceito de competência, homogeneízam a atividade docente aos resultados esperados em avaliações que, orientadas para o ontem, medem apenas conhecimentos já amadurecidos, sem considerar as possibilidades do vir a ser.

Em síntese, os elementos que compõem a organização do ensino, ao se voltarem na busca por uma autonomia intelectual que coloca nos sujeitos a responsabilidade pelo próprio sucesso ou fracasso, confirmam a luta contra o individualismo, que "dentro da escola, assim como na vida social, trata-se de nadar contra a corrente, talvez de uma luta inglória, mas necessária" (RUIZ, 2008, p.231), uma vez que este processo exclui o senso de coletividade presente na universalização do ensino, que, para nós, se "desenvolve na medida em que os sujeitos partilham dos mesmos objetivos e ações para alcançá-los" (BRITO, 2017, p. 66).

Nesse sentido, ancoramo-nos em Leontiev (2004), que, ao tratar da atividade humana, coloca o motivo como elemento orientador das ações realizadas pelos sujeitos, pois, apesar de mobilizarem operações individuais, essas só fazem sentido, se constituídas por meio das relações sociais, como no exemplo da caçada primitiva, em que cada participante possui um estímulo próprio, como alimentar-se ou vestir-se e, para satisfazê-lo, realizam operações individuais, como assustar a caça ou abatê-la. Nesse movimento, mesmo que uma ação retire a possibilidade de realização da outra, juntas, compõem um objetivo em comum, ou seja, representam

a relação do indivíduo aos outros membros da coletividade graças ao qual ele recebe a sua parte da presa, parte do produto da atividade do trabalho coletivo. Esta relação, esta ligação, realiza-se graças às atividades dos outros indivíduos. Isso significa que é precisamente a atividade de outros homens que constitui a base material objetiva da estrutura específica da atividade do indivíduo humano. (LEONTIEV, 2004, p. 84) 
Assim, a coletividade que se apresenta nas relações entre os sujeitos, como no exemplo da caçada, revela-se na relação ensino-aprendizagem professor e estudante, ao realizarem ações com diferentes intencionalidades, partilham de um objetivo em comum: a apropriação da cultura construída historicamente pelo homem, que, por sua vez, se expressa na medida em que possibilita condições para o desenvolvimento humano.

Brito (2017), ao tratar do conceito de coletividade presente em Makarenko (2012), discute que o conceito, ao assumir caráter de processo, e não de premissa para o desenvolvimento, revela-se tanto nas relações como nas ações, o que nos leva a compreender que os elementos integrantes da organização do ensino, como o conceito de formação docente; a identificação do papel social dos sujeitos que participam da relação professor-estudante, em atividade ensino e em atividade aprendizagem; e o papel que a avaliação exerce na relação ensino-aprendizagem, com vistas às possibilidades de desenvolvimento, são interdependentes, integrantes de um processo uno, que em Vigotski (2001) pode ser compreendido como a interligação de complexos vínculos que dão sistematicidade ao processo de humanização.

O esquema seguinte busca esboçar essa interdependência, estruturando os elementos que compõem a organização do ensino em uma trama cujas estruturas, reconhecidas como fenômenos isolados apenas para finalidade de estudo, constituem-se como inerentes à atividade pedagógica, afigurando-se na essência do papel da escola, que, via ações intencionalmente planejadas, conduz os sujeitos à humanização, ou seja, às possibilidades de apropriação dos bens da humanidade, transformando-os dialeticamente. 


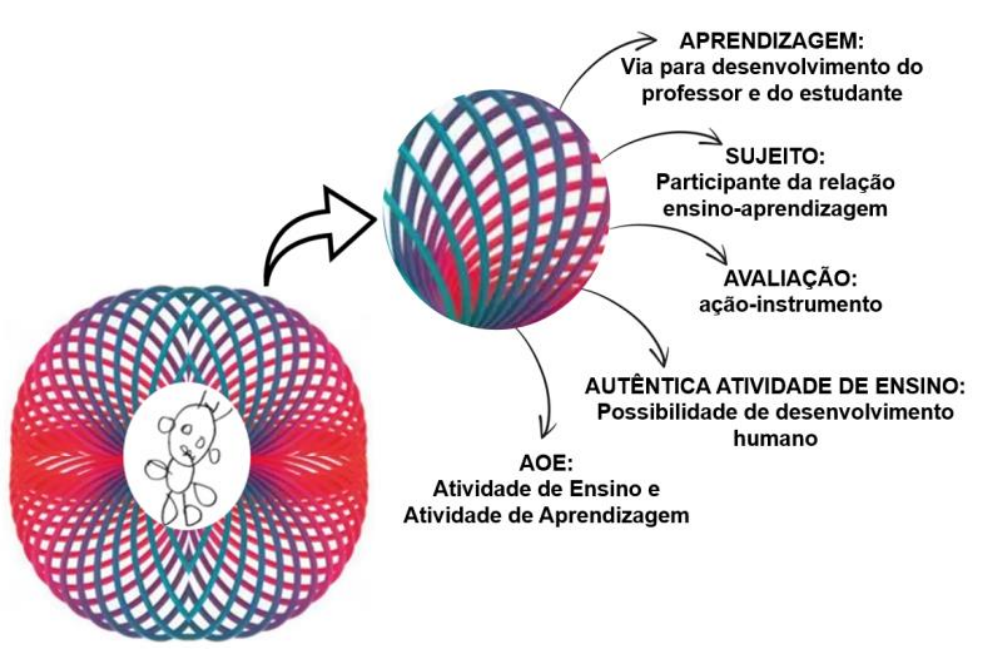

Figura 3. Síntese da relação entre os elementos que compõem a organização do ensino Elaborado pela autora do texto.

A figura humana, representada pelo desenho infantil, reflete-se tanto na figura do professor como na do estudante. Ambos, como sujeitos históricos, a partir de vivências mediadas pelas relações com o mundo, com seus pares e com parceiros mais experientes, não podem ser compreendidos como sujeitos independentes, conforme cita Charlot (1979, p.261), "como a relação entre duas pessoas isoladas e abstratas", mas como parceiros sociais que encontram na atividade (de ensino, de aprendizagem), possibilidades de humanizar-se.

Davydov (1999), ao utilizar a relação entre a lâmpada e a força elétrica para demonstrar o vínculo entre o fenômeno e a essência, explica que a lâmpada, por ser facilmente e frequentemente observada, nesta relação, assemelha-se ao fenômeno, enquanto o movimento entre os polos positivos e negativos, que geram a força elétrica, invisíveis ao olho humano, representa a essência. Dessa mesma maneira, compreendemos a representação do esquema que se revela na atividade humana, como a relação entre o corpo e a vida, em que o fenômeno é representado pelos órgãos dos diferentes sistemas que trabalham continuamente realizando suas funções, para que, juntos, possibilitem a vitalidade como essência humana. Para a organização do ensino, a essência se reflete no desenvolvimento dos sujeitos, articulando-se a partir das possibilidades de "universalização" da cultura construída pelo homem, ao passo 
que os diferentes elementos desta organização se entrelaçam com vistas à transformação qualitativa dos sujeitos.

A partir da teoria histórico-cultural, tal articulação desqualifica a responsabilização até então colocada direta e isoladamente no professor e no estudante. Diante dos resultados de instrumentos avaliativos que assumem papel de medidores da relação ensino-aprendizagem, o pressuposto de que o processo de desenvolvimento se inicia no individual justifica o uso de avaliações que visam aferir conhecimentos interiorizados, os quais se refletem no social e mobilizam práticas e condutas socialmente esperadas, conforme o que se espera da formação do cidadão. Entretanto, "o real processo de desenvolvimento do pensamento infantil [do pensamento humano] não se realiza do individual para o socializado, mas do social para o individual" (VIGOTSKI, 2001, p. 67), ou seja, ocorre primeiro na relação com o outro, na coletividade, e depois é interiorizado, possibilitando assim, um processo dialético de desenvolvimento.

Nesse sentido, cabe discutirmos ainda em que medida a organização do ensino, conduzida pelos referenciais, se expressa na organização do trabalho docente, com intuito de responder às habilidades consideradas pela Base essenciais para o desenvolvimento intelectual e orientadas pela temática da competência. E como podem ser significadas pelos princípios da teoria históricocultural, tirando do indivíduo a responsabilização decorrente dos resultados esperados pelos instrumentos avaliativos, o que "não se trata de uma desresponsabilização, mas de outras formas de responsabilização que existem, não tão verticalizadas, mas combinadas com ações horizontalizadas" (FREITAS, 2013, p. 350). Dessa forma, os sujeitos não assumem a responsabilidade por, mas com o outro no processo de apropriação do patrimônio universal do gênero humano, que se reflete nas relações mediadas pela organização do ensino, para além do desenvolvimento de habilidades próprias do pensamento empírico, mas de modo a possibilitar aos sujeitos vivências que os coloquem em constante movimento de apropriação e significação de sua realidade, com vistas a sua humanização. 


\subsection{Do levantamento de conhecimentos prévios à avaliação da aprendizagem: análise dos princípios de "uma boa situação de aprendizagem"}

Vimos até agora que a publicação da Base Nacional Comum Curricular, em 2017, não trouxe apenas uma referência para que estados e munícipios pudessem se orientar na organização de seus currículos, garantindo e contemplando uma gama mínima de habilidades consideradas indispensáveis à vida dos escolares, no que se refere à formação do cidadão e à qualificação para o trabalho. Seu caráter regulador, ao estabelecer aprendizagens específicas para cada ano da educação infantil e do ensino fundamental, segundo Freitas (2014), tem desencadeado a homogeneização de muitas das práticas e condutas que compõem a ação docente, afetando, sobretudo, aquilo que diz respeito à relação ensino-aprendizagem, assim como a função social da escola e do ensino.

Tomando as práticas e as condutas como primeiro ponto de análise, Freitas (2017) aponta para o uso de instrumentos avaliativos, destacando como um dos efeitos da BNCC a substituição da avaliação, antes planejada e organizada pelo professor, por avaliações em larga escala que, como explicita o próprio documento, não mais se configuram como uma ação intrínseca à atividade docente, mas como eficaz estratégia para verificação de resultados, alinhando-se aos objetivos das políticas de responsabilização que se concentram no aumento quantitativo dos índices.

Essa relação, que se situa entre a configuração dada à avaliação pela BNCC e a aplicação de avaliações a serviço das políticas de responsabilização, explicita-se em um dos objetivos do documento, que diz:

Construir e aplicar procedimentos de avaliação formativa de processo ou de resultado que levem em conta os contextos e as condições de aprendizagem, tomando tais registros como referência para melhorar o desempenho da escola, dos professores e dos alunos. (BRASIL, 2017, p. 17)

Assim, ao atrelar seus resultados à busca de efeitos que visem ao aumento dos índices como representação de melhoria de desempenho, a 
avaliação, antes subordinada ao planejamento docente, torna-se uma ferramenta superior e passa a orientar o trabalho pedagógico. Em consequência, contribui para o desenvolvimento das habilidades, que, assim como temos discutido, não necessariamente correspondem à essência do ensino como possibilidade de desenvolvimento humano, de acordo com o que é defendido pela teoria histórico-cultural.

Outro ponto de análise se refere à essência subjacente à função social do ensino que objetiva a formação cidadã e a qualificação para o trabalho, o que, na Base, é representado pelo princípio de competência, declarado como unificador dos "direitos de aprendizagem". Assim afirma o documento:

\begin{abstract}
Ao longo da Educação Básica, as aprendizagens essenciais definidas na BNCC devem concorrer para assegurar aos estudantes 0 desenvolvimento de dez competências gerais, que consubstanciam, no âmbito pedagógico, os direitos de aprendizagem e desenvolvimento [...] Ao definir essas competências, a BNCC reconhece que a "educação deve afirmar valores e estimular ações que contribuam para a transformação da sociedade, tornando-a mais humana, socialmente justa e, também, voltada para a preservação da natureza" (BRASIL, 2013), mostrando-se também alinhada à Agenda 2030 da Organização das Nações Unidas - ONU. (BRASIL, 2017, p. 8)
\end{abstract}

Portanto, a partir dos argumentos apresentados pelo excerto, poderíamos questionar: em que medida o ensino escolarizado, ao ser organizado em coerência com os princípios revelados pela Base, poderia não desenvolver nos escolares condições para que eles possam transformar a sociedade em um espaço mais humano e justo? Ou ainda, retomando a questão da avaliação: em que medida o uso de instrumentos avaliativos, verificadores de desempenho, poderiam assumir um papel desfavorável à consolidação dos direitos de aprendizagem?

Em resposta a tais questionamentos, não bastaria uma análise da relação direta entre o que está posto pela BNCC e a organização do ensino. A propósito, parece-nos interessante mencionar que Vigotski (2001), ao tratar da relação entre o pensamento e a linguagem, nos leva a olhar para o que está além da correspondência direta entre a palavra e sua definição e afirma que sua essência reside no desenvolvimento do seu significado, compreendido como elemento dinâmico e inesgotável. Ressalta que o sentido atribuído à palavra é orientado pelo contexto no qual ela é inserida, ou seja, "a palavra só adquire sentido na 
frase, e a própria frase só adquire sentido no contexto do parágrafo, o parágrafo no contexto do livro, o livro no contexto de toda a obra do autor" (VIGOTSKI, 2001, p. 466).

Com efeito, para compreendermos a relação entre o que está posto pela BNCC e o sentido da ponderação de Vigotski para organização do ensino, bem como dos elementos que o compõem, é importante compreendermos as circunstâncias do movimento de elaboração e inserção deste referencial no contexto político e social que vem orientando a educação brasileira após a década de 90 com políticas hegemônicas, que, como explicam Marsiglia et al. (2017), revestidas sob a roupagem do lema de "educação de qualidade", têm levado adiante o projeto educativo da classe dominante (dos reformadores empresariais ${ }^{4}$ ) a favor do avanço e da consolidação de princípios capitalistas para formar as futuras gerações de trabalhadores.

Dentre esses princípios, como destacamos em outros momentos, podemos citar a questão da aprendizagem docente que, aos olhos da BNCC, configura-se como "contínuo aperfeiçoamento dos processos de ensino e aprendizagem" (BRASIL, 2017, p. 17), o que, em nossa análise, faz referência ao que Araujo (2003, p. 19) explica como o "aprimoramento de técnicas de ensino", em que a formação do professor se relaciona principalmente à concepção empírica do "saber fazer". Tal perspectiva, como discutimos anteriormente, não revela a concepção teórica que envolve a reflexão sobre os processos de aprendizagem e desenvolvimento humano.

Nessa direção, as concepções que sustentam as práticas e as condutas educacionais, bem como aquelas que regem a formação docente, são orientadas por princípios capitalistas, do mesmo modo que a função social da escola responde ao que Freitas (2013) apresenta como "raciocínio empresarial", que busca a padronização de técnicas, práticas e metas, além de estratégias que visam ao aprimoramento do fluxo educacional, mas não garantem e nem mesmo promovem, a verdadeira função social do ensino escolarizado, que se encontra para além dos números obtidos por meio dos instrumentos avaliativos.

\footnotetext{
${ }^{4}$ Marsiglia et al. (2017) apresenta como exemplo de alguns dos reformadores empresariais a Fundação Itaú Social, Fundação Lemann, Fundação Roberto Marinho, Instituto Unibanco, Instituto Ayrton Senna, Instituto Natura, CENPEC, além do organismo Todos pela Educação, como alguns dos representantes dos aparelhos privados de hegemonia da classe empresarial.
} 
Moraes (2008) explica que o papel da avaliação como instrumento alinhase aos objetivos econômicos, que prezam a manutenção de um projeto escolar que almeje a adaptação dos indivíduos, fazendo permanecer o afastamento entre os sujeitos e o conhecimento historicamente produzido pela humanidade:

\begin{abstract}
Essa forma de avaliação filia-se ao projeto de escola que busca a adaptação dos indivíduos no sentido de manter a ordem social e econômica vigente, isto é, a manutenção do sistema econômico baseado na propriedade privada dos meios de produção. Uma sociedade em que os meios de produção não são socializados, o acesso ao conhecimento historicamente acumulado pela humanidade também se torna propriedade privada. (MORAES, 2008, p. 28-29)
\end{abstract}

Tendo em conta o que foi aqui ponderado, retomamos as questões apresentadas, respondendo que os preceitos propostos pela BNCC, ao passo que se alinham aos princípios da sociedade capitalista, desenvolvem valores para a conservação do conhecimento como bem privado, uma vez que coloca no sujeito a responsabilidade pela formação de competências individuais, impelidas por metas de aprendizagem e por políticas que buscam abrandar as desigualdades de acesso e reduzem a grandeza da universalização do ensino à assimilação de saberes laborais. Em suma, dialogam com a aparente finalidade social da escola, mas não com sua real função, pois priorizam a formação minimalista dos escolares, preservando apenas os mecanismos do pensamento empírico que separam o conhecimento de seu uso (DAVIDOV, 2017); e restringem a educação apenas a satisfazer necessidades básicas e imediatas de aprendizagem, predominantes no trabalho simples que, provavelmente, fará parte da vida de grande parcela dos estudantes (MARSIGLIA et al., 2017).

Sobre esta satisfação, que equaliza os direitos de aprendizagem ao direito à educação, mercantilizado pelo desenvolvimento de competências, Marsiglia et al. (2017), destacam também que

historicamente, a classe empresarial tem atuado para subordinar a escola pública às concepções que visam distanciar o conhecimento das necessidades humanas reais, sugerindo que o domínio amplo do saber sistematizado seria supérfluo à classe trabalhadora em função de suas necessidades imediatas de vida. Com efeito, a política educacional no Brasil tem reiterado a tendência de apropriação privada das formas mais desenvolvidas dos conhecimentos científicos, filosóficos e artísticos produzidos pela humanidade, o que se observa, inclusive, no âmbito das reformas curriculares. (MARSIGLIA et al., 2017 , p. 113, grifo nosso) 
Assim, ousamos destacar que desde as orientações dadas pelos órgãos internacionais, como a ONU e o Banco Mundial, além das metas propostas a partir da Declaração de Jomtien, os documentos orientadores da educação brasileira observados por nós a partir da década de 90 alinham-se à reprodução de concepções que compreendem que o papel da escola é buscar reparar os prejuízos causados pela pobreza. E garantem, em lei, mínimas oportunidades de acesso que, em síntese, preparam para o trabalho e oportunizam saberes essenciais à resolução de problemas costumeiros, que distanciam da classe trabalhadora o que seria considerado dispensável ao seu cotidiano, reservando as condições de apropriação dos bens culturais a um restrito grupo (MARSIGLIA et al., 2017).

Exemplos desse distanciamento, observados anteriormente por Davidov (2017), referem-se à organização escolar russa. O autor, ao tratar de seus princípios didáticos, utiliza o termo "escola tradicional", para referir-se a um sistema de educação que, entre outras características, organiza-se com base em uma seleção de conteúdos capazes de atender à época capitalista e à formação do homem próprio daquela sociedade. Portanto, a escola tradicional representaria um

\footnotetext{
sistema relativamente único de educação europeia, que, em primeiro lugar formou-se no período de nascimento e florescimento da produção capitalista e ao qual serviu; em segundo lugar, foi fundamentado nos trabalhos de Y. Komenski, I. Pestalozzi, A Diesterweg, K. Ushinski, além de outros destacados pedagogos desse período; e, em terceiro lugar, conservou até agora seus princípios iniciais como base para seleção de conteúdo e os métodos de ensino na escola atual. As fontes da unidade e da prolongada permanência desse sistema são, por um lado, o caráter comum dos objetivos sociais da educação escolar, próprio de toda época capitalista e, por outro lado, o caráter comum das vias e dos meios para formar as capacidades psíquicas do homem no alcance desses objetivos. (DAVIDOV, 2017, p. 211)
}

Tal caracterização, evidenciada pelo autor em 1987, nos impressiona por sua atualidade, pois nos valemos de sua tradução, publicada 30 anos após o original, em um país com traços tão diferentes da Rússia, mas que conserva os objetivos sociais próprios da época capitalista, preocupados em estimular, com princípios da "educação em massa", apenas aqueles conhecimentos elementares para se obter uma profissão e viver em sociedade: ler, escrever, 
contar e resolver problemas habituais, mantendo o elo com os conhecimentos cotidianos que a criança recebe no seio familiar, antes de entrar para escola, e que, apesar de fundamentais à realização de tarefas corriqueiras, não promovem o desenvolvimento do pensamento teórico (DAVIDOV, 2017).

Nesse sentido, o autor destaca que, para escolas que correspondem à caracterização da escola tradicional, como podemos observar no caso brasileiro, no que se refere à organização do ensino orientado pela Base,

o caráter científico é apenas declarado; é compreendido de forma estritamente empírica, e não em sua verdadeira significação dialética, ou seja, como procedimento especial de reflexo mental da realidade por meio da ascensão do abstrato ao concreto. (DAVIDOV, 2017, p. 217)

Desse modo, o que se tem priorizado no ensino corresponde à função social dada à escola pela Constituição de 88, que, corroborada pelos princípios expressos pelos órgãos internacionais, condicionou a elaboração de políticas públicas educacionais, orientando-as desde então e firmando-se com a publicação da BNCC que caminha, levando adiante a concepção de uma educação que possui em seu cerne a formação do cidadão e sua qualificação para o trabalho, que, nas palavras de Davidov (2017, p. 213), prepara "para a produção capitalista somente um homem parcial, que, como um parafuso, servia [e serve] ao maquinário e atuava [e atua] como parte subordinada deste".

Entretanto, compreendemos que o verdadeiro papel da educação, no âmbito do ensino escolarizado, precisa levar em conta que o ensino, como possibilidade de desenvolvimento, deve fazer a criança avançar, passando do que ela sabe - daquilo que realiza sozinha, em seu cotidiano - para aquilo que ela não sabe, mas que virá a saber, mediante a qualidade das situações intencionalmente elaboradas para este fim. Porém compreendemos que tanto 0 professor como o estudante, que ocupam um espaço social como sujeitos históricos, reconhecendo-se para além do sujeito cidadão, encontram, nas possibilidades de apropriação dos conhecimentos construídos como produto da atividade humana, a possibilidade de construir uma mudança qualitativa em seu pensamento, o que lhes permite compreender novos significados e ampliar seus horizontes, e lhes possibilita modificar os modos de interação com o meio, 
transformando, assim, também o seu pensamento (ROSA; MORAES; CEDRO, 2017).

Nas palavras de Vigotski (2001, p. 334), qualificamos a função social da educação como aquela que

\begin{abstract}
motiva e desencadeia para a vida toda uma série de funções que se encontravam em fase de amadurecimento e na zona de desenvolvimento imediato. É nisso que consiste o papel principal da aprendizagem no desenvolvimento. É isto que distingue a educação da criança do adestramento dos animais. É isto que distingue a educação da criança, cujo objetivo é o desenvolvimento multilateral da educação especializada, das habilidades técnicas como escrever à máquina, andar de bicicleta, etc., que não revelam nenhuma influência substancial no desenvolvimento.
\end{abstract}

Todavia, o que temos encontrado ao longo das habilidades deliberadas pela BNCC, desde a educação infantil até o nono ano do ensino fundamental, apresenta estreito alinhamento ao identificado por Davidov (2017) como princípios didáticos da escola tradicional que, comumente, fazem permanecer o pensamento empírico, que, por sua vez, segrega o conhecimento científico do seu uso, por considerá-lo supérfluo ao trabalhador.

Exemplo disso apresentamos no Quadro 2, em que organizamos algumas das habilidades relativas ao ensino da Matemática para os primeiros anos do ensino fundamental (turmas do primeiro ao quinto ano) que, contrário ao que defendemos, explicitam aprendizagens que se situam no campo do pensamento empírico-utilitarista, atrelando o ensino escolarizado ao desenvolvimento de saberes voltados ao cotidiano:

\begin{tabular}{|c|l|}
\hline $\begin{array}{c}\text { Habilidades a serem desenvolvidas pelos estudantes do 1. ao 5. ano } \\
\text { do Ensino Fundamental em Matemática }\end{array}$ \\
\hline Cód. Alfanumérico & \multicolumn{1}{c|}{ Descrição da habilidade } \\
\hline EF01MA15 & $\begin{array}{l}\text { Comparar comprimentos, capacidades ou massas, } \\
\text { utilizando termos como mais alto, mais baixo, mais } \\
\text { comprido, mais curto, mais grosso, mais fino, mais } \\
\text { largo, mais pesado, mais leve, cabe mais, cabe menos, } \\
\text { entre outros, para ordenar objetos de uso cotidiano. }\end{array}$ \\
\hline EF01MA19 & $\begin{array}{l}\text { Reconhecer e relacionar valores de moedas e cédulas } \\
\text { do sistema monetário brasileiro para resolver } \\
\text { situações simples do cotidiano do estudante. }\end{array}$ \\
\hline
\end{tabular}




\begin{tabular}{|c|l|}
\hline EF01MA20 & $\begin{array}{l}\text { Classificar eventos envolvendo o acaso, tais como } \\
\text { "acontecerá com certeza", "talvez aconteça" e "é } \\
\text { impossível acontecer", em situações do cotidiano. }\end{array}$ \\
\hline EF02MA21 & $\begin{array}{l}\text { Classificar resultados de eventos cotidianos } \\
\text { aleatórios como "pouco prováveis", "muito prováveis", } \\
\text { "improváveis" e "impossíveis". }\end{array}$ \\
\hline EF04MA22 & $\begin{array}{l}\text { Ler e registrar medidas e intervalos de tempo em } \\
\text { horas, minutos e segundos em situações relacionadas } \\
\text { ao seu cotidiano, como informar os horários de início e } \\
\text { término de realização de uma tarefa e sua duração. }\end{array}$ \\
\hline EF04MA24 & $\begin{array}{l}\text { Registrar as temperaturas máxima e mínima diárias, } \\
\text { em locais do seu cotidiano, e elaborar gráficos de } \\
\text { colunas com as variações diárias da temperatura, } \\
\text { utilizando, inclusive, planilhas eletrônicas. }\end{array}$ \\
\hline EF04MA26 & $\begin{array}{l}\text { Identificar, entre eventos aleatórios cotidianos, } \\
\text { aqueles que têm maior chance de ocorrência, } \\
\text { reconhecendo características de resultados mais } \\
\text { prováveis, sem utilizar frações. }\end{array}$ \\
\hline
\end{tabular}

QUADRO 2. Habilidades a serem desenvolvidas pelos estudantes do $1 .^{\circ}$ ao $5 .^{\circ}$ ano do E.F. Organizado pela autora. Fonte: BNCC (BRASIL, 2017, p. 279-291, grifos nossos).

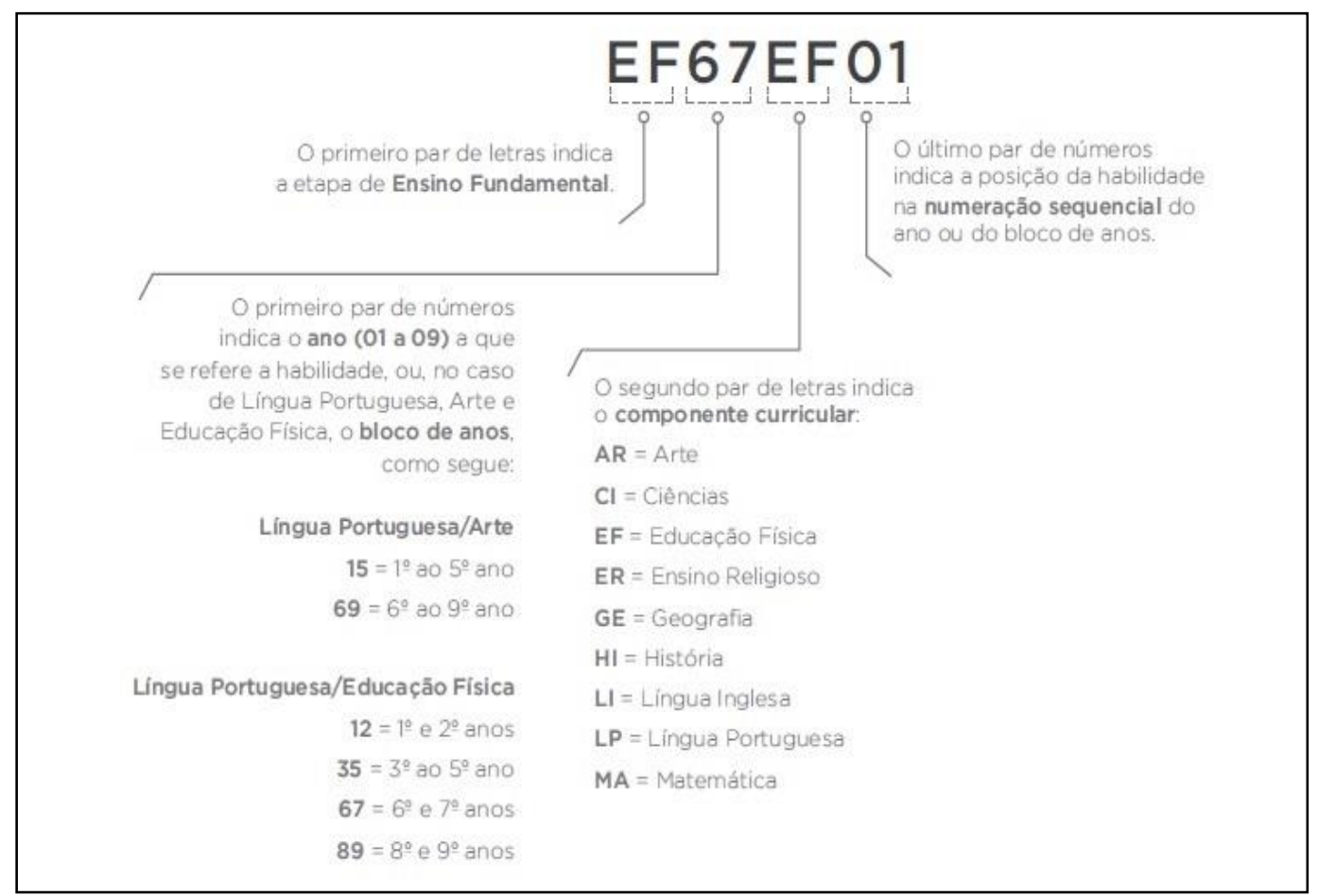

Figura 4. Informações complementares para leitura do código alfanumérico. Fonte: BNCC (BRASIL, 2017, p. 30).

As habilidades destacadas, ao se remeterem a ações práticas, como "comparar [...] para ordenar objetos de uso cotidiano" e "reconhecer e relacionar 
[...] para resolver situações simples do cotidiano", afastam dos escolares as possibilidades de desenvolvimento do pensamento teórico, pois, assim como nos mostra Davidov (2017), conservam aprendizagens espontâneas, características do meio circundante que, por sua vez, contribuem para o distanciamento entre o que se ensina e as possibilidades de desenvolvimento do pensamento teórico, uma vez que, "na estruturação das disciplinas na escola primária, conserva-se o elo com os conhecimentos cotidianos e correntes que a criança recebe antes de entrar para a escola" (DAVIDOV, 2017, p. 214).

O ensino, nesse sentido, ao organizar-se no cumprimento de habilidades que expressam o desenvolvimento de saberes laborais, orienta-se pela operacionalização imediata dos conceitos que se ligam às suas características comuns e aparentes, limita o desenvolvimento de generalizações e de apropriações dos conhecimentos científicos, encurta as possibilidades do escolar para "estabelecer as inter-relações que constituem o sistema integral, universal e transitório, dos fenômenos e dos objetos" (ROSA; MORAES; CEDRO, 2016, p. 89), que Ihes permitem transcender da relação de adaptação à sociedade a sua emancipação, uma vez que, destituídos do papel de cidadão, passam a ter condições para desenvolver-se com vistas à sua humanização.

Nesse sentido, Davidov (2017), ao explicar que, para escola tradicional, a formação dos conceitos parte da capacidade de apropriação advinda da experiência sensorial, o autor questiona "que sabedoria contém esses princípios, se eles são expressão de ideias tão triviais?" (DAVIDOV, 2017, p. 214). Em resposta, o próprio autor afirma que "mazela e indiferença correspondem plenamente aos objetivos finais da escola tradicional" (p. 214), uma vez que esta assume uma prática escolar que se revela na indistinção entre os conhecimentos científicos e os conhecimentos cotidianos, preservando a educação empíricoutilitarista e promovendo, em decorrência disto, o desenvolvimento do pensamento empírico-classificador, em que o conteúdo do ensino se refere às características evolutivas dos estudantes e ajusta-se à construção dos conceitos às representações básicas (classificadoras), que, por sua vez, justificam a pobreza do ensino da escola tradicional, que "contradiz com a ideia da educação que promove o desenvolvimento" (p. 215).

Nós, ao tratarmos da avaliação como um dos elementos que compõem a organização do ensino, em especial o ensino da Matemática, que tem se 
orientado pelos princípios da BNCC e, antes, por outros reguladores, igualmente impregnados por abordagens neoliberais, buscamos na pergunta de Davidov elementos que, a favor do nosso objeto de análise, permitam-nos questionar: quais sabedorias apresentam os resultados das avaliações que, no papel de ferramenta do trabalho pedagógico, medem as habilidades apreendidas, se estas são expressão de conhecimentos tão triviais?

Em resposta a esta questão, retomamos a análise deste documento, buscando destacar em que medida seus objetos corresponderiam ao desenvolvimento dessas habilidades, bem como ao papel da escola, naturalizado ao longo dos anos pelos documentos reguladores, reafirmado por políticas públicas voltadas à educação, que têm se constituído em coerência com as ideias próprias dos reformadores empresariais, que seguem o movimento de uma educação que forme o cidadão e o qualifique para o trabalho, justificando que os índices resultantes destes instrumentos representam o domínio de habilidades laborais como sinônimos de aprendizagens fundamentais para o desenvolvimento de uma autonomia intelectual que, em síntese, configura-se equivocadamente como ápice do ensino escolarizado, uma vez que este corresponde apenas à assimilação de conceitos que promovem 0 desenvolvimento de habilidades voltadas à aparência dos conceitos.

Este movimento pode ser observado no exemplo em que o professor, ao abordar o tema de medidas de tempo, que envolve a leitura de horas, como expresso pela unidade temática Grandezas e Medidas, considera para o ensino deste conceito o desenvolvimento das seguintes habilidades:

\begin{tabular}{|c|l|}
\hline \multicolumn{2}{|c|}{ Habilidades referentes ao ensino de horas no EF } \\
\hline Cód. Alfanumérico & \multicolumn{1}{c|}{ Descrição da habilidade } \\
\hline EF03MA23 & $\begin{array}{l}\text { Ler horas em relógios digitais e em relógios analógicos } \\
\text { e reconhecer a relação entre hora e minutos e entre } \\
\text { minuto e segundos. }\end{array}$ \\
\hline EF04MA22 & $\begin{array}{l}\text { Ler e registrar medidas e intervalos de tempo em } \\
\text { horas, minutos e segundos em situações relacionadas } \\
\text { ao seu cotidiano, como informar os horários de início e } \\
\text { término de realização de uma tarefa e sua duração. }\end{array}$ \\
\hline
\end{tabular}

QUADRO 3. Habilidades referentes ao ensino de horas no EF. Fonte: Brasil (2017, p. 287291). Organizado pela autora. 
Para responder ao desenvolvimento dessas habilidades, é comum que o professor elabore uma sequência didática, reservando momentos para 0 levantamento de hipótese em uma conversa inicial; e problematizações, a fim de aproximar da realidade dos estudantes o conteúdo a ser estudado, bem como o planejamento de intervenções, com o objetivo de levá-los a reconhecer, identificar, relacionar, classificar, ler e registrar horas.

Para isso, o relógio de parede da sala de aula assume papel de material de apoio, pois frequentemente é utilizado em situações de observação do movimento dos ponteiros, do ritmo de cada um para marcar as horas, os minutos e os segundos. É possível, ainda, que o professor, ao contextualizar este estudo, discuta com sua turma as transformações desses marcadores de tempo ao longo dos anos, que, desde a ampulheta até o relógio digital, representaram um grande progresso na vida das pessoas, bem como nos modos de organização das sociedades.

Em outras situações, para crianças menores, é esperada a aplicação de jogos para o reconhecimento e a leitura de horas ou, ainda, a pintura de desenhos que retratam este objeto, bem como a construção de um relógio individual para que cada um possa experimentar a movimentação dos ponteiros. Já para os maiores, é comum a aplicação de problemas para que, em situações comuns ao cotidiano, possam calcular o tempo percorrido entre uma atividade e outra, o tempo de duração de um evento e até mesmo sejam motivados a colocar seus conhecimentos em prática, criando outros problemas para que os colegas de classe possam resolver.

Com isto, o professor pressupõe que os estudantes receberam todas as informações necessárias para apropriarem-se dos conceitos que permeiam estas tarefas e, então, aplica uma avaliação a fim de verificar os resultados da aprendizagem e atribui àqueles com mais respostas certas a conquista da autonomia intelectual decorrente do desenvolvimento das habilidades expressas pela BNCC.

Para expor este exemplo, recorremos à análise de Davydov (2017) acerca dos princípios da escola tradicional, em que o autor aponta para a presença de quatro princípios orientadores: o princípio do caráter sucessivo, da acessibilidade, do caráter consciente e do caráter visual, evidenciando que, para 
este modelo educacional, um aspecto geral do ensino estaria relacionado à dimensão utilitária, que induz a concepção de aplicabilidade do conhecimento, pois, de outro modo, este se tornaria dispensável à vida do estudante. (DAVIDOV, 2017; MARSIGLIA et al., 2017; ROSA; MORAES; CEDRO, 2016).

Nesta perspectiva, o primeiro ponto de análise trata do princípio do caráter sucessivo que, como nos explica o autor, diz respeito tanto à conservação dos conhecimentos cotidianos, como à indistinção entre as "particularidades e a especificidade da etapa seguinte na aquisição de conhecimentos em comparação com a etapa precedente" (DAVIDOV, 2017, p. 214), o que, neste exemplo, refere-se ao desenvolvimento de habilidades que não possibilitam mudança qualitativa no pensamento do estudante - seja ele estudante do primeiro ou do quinto ano -, que, ao longo de sua jornada escolar, lida apenas com aqueles conhecimentos que se situam no campo empírico, ou seja, independentemente da etapa de ensino, as habilidades a serem desenvolvidas se estenderão à margem da observação, da comparação ou ainda da classificação apenas dos elementos externos aos conteúdos.

A mudança observada em relação os conteúdos ensinados, neste caso, se expressa por meio do caráter quantitativo, uma vez que nos primeiros anos as tarefas estão relacionadas a desenhos, pinturas e jogos, enquanto que nos anos seguintes o ensino é marcado pela exaustiva resolução de problemas e cálculos, e, mecanicamente, o estudante emprega estratégias aprendidas, mas que não necessariamente se configuram como possibilidade de passagem do pensamento empírico ao teórico.

A conservação deste tipo de pensamento, ao atrelar a relação do sujeito sobre o objeto, revela-se nas práticas e nas condutas do professor, cujo objeto de ensino se centra no desenvolvimento de habilidades voltadas, como já dissemos, ao reconhecimento, à leitura e ao registro de horas e intervalos de tempo, a partir de representações observáveis que se vinculam à operação do conhecimento dado em sua forma final. E este, por sua vez, abrevia o processo histórico de desenvolvimento, permitindo ao estudante apenas uma breve orientação "no sistema de conhecimentos já acumulados sobre as peculiaridades e os traços externos de objetos e fenômenos isolados da natureza e da sociedade" (DAVIDOV, 1988, p. 144, tradução nossa). 
A abreviação deste processo desencadeia o princípio do caráter consciente que, como nosso segundo ponto de análise, se refere ao desenvolvimento de cognições que se materializam por meio de exemplos e comparações verbais, habitualmente "correlacionadas a uma imagem sensorial completamente definida e precisa" (DAVIDOV, 2017, p. 216), que inibem o desenvolvimento de mecanismos do pensamento, capazes de realizar generalizações que criam a "possibilidade para que os pensamentos passem a um plano novo e mais elevado de operações lógicas" (VIGOTSKI, 2001, p. 376).

Tais generalizações, como nos explica Vigotski (2001), não ocorrem no movimento de comparação e discriminação ou no estabelecimento de relações simples entre os conceitos, mas na unidade dos conceitos e das operações possíveis para compreendê-lo, ou seja, dentro de um sistema de conceitos, pois

\begin{abstract}
fora do sistema, os conceitos mantêm com o objeto uma relação diferente daquela que mantêm ao ingressarem em um determinado sistema. A relação da palavra "flor" com o objeto, na criança que ainda desconhece as palavras "rosa", "violeta", "lírio" e na criança que as conhece, acaba sendo inteiramente diversa. Fora do sistema, nos conceitos só são possíveis vínculos que se estabelecem entre os próprios objetos, isto é, vínculos empíricos. (VIGOSTKI, 2001, p.382)
\end{abstract}

Assim, ao promover comparações diretas, que se relacionam entre 0 objeto e o conceito situado fora da compreensão de que este é parte de um sistema, o ensino, como nos explica Davidov (2017), volta-se à valorização apenas das observações das propriedades comuns dos objetos, desenvolvendo nos sujeitos mecanismos do pensamento empírico-classificador, que, por sua vez, se apresentam de modo insuficiente para desenvolver o pensamento teórico, pois "para assimilar o espírito autêntico da ciência contemporânea e os princípios de uma relação criativa, ativa e de profundo conteúdo em face da realidade" (DAVIDOV, 1988, p. 144, tradução nossa), é necessário que o estudante não receba o conceito pronto, mas que, em sua prática escolar, possa recuperar sua necessidade humana de desenvolvimento, para apropriar-se das relações que construirão novas conexões. E estas servirão de fontes para as abstrações e generalizações inerentes ao desenvolvimento do pensamento teórico que compreende o conceito como parte de um sistema, e não como um evento da humanidade que se deu de modo isolado (DAVIDOV, 2017; VIGOSTKI, 2001). 
O terceiro ponto de análise se refere ao princípio do caráter visual que, assim como para a escola tradicional, bem como para este exemplo, a organização do ensino, faz-se pela compreensão sobre o processo de desenvolvimento do pensamento infantil, relacionando-o à psicologia da sensibilidade que, equivocadamente, fundamenta-se na tese de que o ensino deve operar com os conhecimentos presentes na criança, e o manuseio do objeto ou de qualquer material palpável, como o uso do relógio de parede ou de madeira (material comum ao meio pedagógico) ou mesmo a utilização de diferentes figuras, se justificaria como uma ação necessária para 0 desenvolvimento dos estudantes, pois, ao manusear ou ao observar imagens, ao passo que resgataria lembranças de experiências anteriores, construiria novas, a partir das sensações e das emoções vivenciadas.

Todavia, a orientação do ensino pelos princípios do caráter visual está estritamente ligada à redução do conceito ao empirismo constitutivo "do pensamento de tipo racionalista discursivo-empírico, classificador, em cuja base encontra-se somente o reflexo das propriedades externas, sensoriais e dadas do objeto" (DAVIDOV, 2017, p. 217), que, por sua vez, não levam ao desenvolvimento do pensamento teórico.

Nesta direção, destacamos a compreensão do professor acerca do processo de desenvolvimento do pensamento humano que se evidencia neste exemplo na sequência de tarefas organizadas de modo linear e progressivo, adequadas, principalmente, à condição etária e evolutiva, própria do princípio da acessibilidade que, como nosso quarto ponto de análise, se refere à organização estruturalista das tarefas. Atividades que envolvam o cálculo para descobrir a duração de um evento ou o tempo percorrido entre um acontecimento e outro, certamente, não seriam abordadas em uma turma de primeiro ano, pois, pela imaturidade, estes estudantes não teriam condições de resolvê-las, cabendoIhes a manipulação de objetos, tarefas de pintura, construção e manuseio de relógio, além de observação, descrição e comparação de imagens, para que, em situações futuras, possam recorrer a esta base como condição para realizar tarefas mais elaboradas ou complexas.

Ao fixar suas características evolutivas na condição etária, em que a concepção acerca do processo de desenvolvimento do pensamento se baseia em representações graduais, que se orientam na premissa de que, para sua 
promoção, o ensino deve organizar-se contemplando atividades que partem do simples ao complexo, bem como do concreto ao abstrato - em que o concreto é representado pelo manuseio de objetos como base para futuras ações mentais, as abstrações -, o professor desconsidera que o aprendizado que faz a criança avançar situa-se nas possibilidades de apropriação daquilo que ela não sabe, mas de que poderá apropriar-se a partir de situações desencadeadoras intencionalmente planejadas, uma vez que essas situações promovem, em seu interior, um motivo gerador de sentido, assim como aquele que, na gênese do desenvolvimento do conceito, levou a humanidade à sua construção, possibilitando que o motivo da necessidade humana possa, nesta situação, tornar-se também o motivo da necessidade do estudante (MOURA et al., 2010) e proporcionar a ele o envolvimento na busca coletiva por uma solução que tenha "como fim a satisfação de uma determinada necessidade à semelhança do que pode ter acontecido em certo momento histórico da humanidade" (MOURA et al., 2010, p.224).

O Quadro 4 apresenta uma síntese do nosso movimento de estudo, no qual nos respaldamos na análise realizada por Davidov acerca dos princípios da escola tradicional, para analisarmos um exemplo de organização de uma sequência didática para o ensino das horas, que coloca em evidência a orientação do trabalho pedagógico a partir das habilidades expressas pela Base e que conservam o desenvolvimento das propriedades subjacentes ao pensamento empírico.

\begin{tabular}{|c|c|c|}
\hline \multicolumn{3}{|c|}{$\begin{array}{l}\text { Síntese da análise de uma sequência didática para o ensino de medidas } \\
\text { de tempo }\end{array}$} \\
\hline $\begin{array}{l}\text { Evidência expressa pelo } \\
\text { exemplo }\end{array}$ & $\begin{array}{l}\text { Princípios da escola } \\
\text { tradicional }\end{array}$ & \\
\hline $\begin{array}{l}\text { Organização de uma } \\
\text { sequência didática de tarefas } \\
\text { que respondem ao } \\
\text { desenvolvimento de } \\
\text { habilidades que buscam } \\
\text { aproximar o conteúdo a ser }\end{array}$ & $\begin{array}{l}\text { Caráter sucessivo } \\
\text { Conserva-se o elo com os } \\
\text { conhecimentos cotidianos e } \\
\text { correntes que a criança } \\
\text { recebe antes de entrar para a } \\
\text { escola. Também indica que, } \\
\text { quando a educação se }\end{array}$ & $\begin{array}{l}\text { O ensino organizado para } \\
\text { responder às habilidades } \\
\text { propostas pela Base, não } \\
\text { possibilita } \\
\text { qualitativas no pensamento } \\
\text { do estudante por levá-los, }\end{array}$ \\
\hline
\end{tabular}




\begin{tabular}{|c|c|c|}
\hline $\begin{array}{l}\text { estudado à realidade dos } \\
\text { estudantes, com o objetivo de } \\
\text { levá-los a reconhecer, } \\
\text { identificar, } \\
\text { classificar, ler e relacionar, } \\
\text { horas. }\end{array}$ & $\begin{array}{l}\text { estende além dos anos } \\
\text { iniciais, não se diferenciam } \\
\text { de maneira clara as } \\
\text { particularidades e a } \\
\text { especificidade da etapa } \\
\text { seguinte na aquisição de } \\
\text { conhecimentos } \\
\text { comparação com a etapa } \\
\text { precedente (DAVIDOV, 2017, } \\
\text { p. 214). }\end{array}$ & $\begin{array}{l}\text { durante sua jornada escolar, } \\
\text { a lidar apenas com aqueles } \\
\text { conhecimentos que se } \\
\text { situam no campo empírico. }\end{array}$ \\
\hline $\begin{array}{l}\text { Organização do trabalho } \\
\text { pedagógico à parte de } \\
\text { sequência didática, em que, a } \\
\text { fim de realizar o } \\
\text { levantamento } \\
\text { conhecimentos prévios dos } \\
\text { estudantes, desde a } \\
\text { conversa inicial às situações } \\
\text { problematizadoras que } \\
\text { buscam aproximar do } \\
\text { cotidiano do estudante, o } \\
\text { conceito a ser estudado e o } \\
\text { desenvolvimento das tarefas } \\
\text { partem de apresentações } \\
\text { verbais advindas apenas do } \\
\text { professor, e este, ao assumir } \\
\text { o papel de detentor das } \\
\text { informações, necessita } \\
\text { didatizá-las com exemplos } \\
\text { concretos, para que possam } \\
\text { ser compreendidas pelos } \\
\text { estudantes. }\end{array}$ & $\begin{array}{l}\text { Caráter consciente } \\
\text { Em primeiro lugar, todo } \\
\text { conhecimento se apresenta } \\
\text { em forma de abstrações } \\
\text { verbais claras } \\
\text { sucessivamente } \\
\text { desdobradas (a informação } \\
\text { submetida ao professor é a } \\
\text { forma mais geral de } \\
\text { verificação dos } \\
\text { conhecimentos). } \\
\text { segundo lugar, cada } \\
\text { abstração verbal deve ser } \\
\text { correlacionada, pela criança, } \\
\text { com uma imagem sensorial } \\
\text { completamente definida e } \\
\text { precisa, de preferência de } \\
\text { com exemplos concretos } \\
\text { (DAVIDOV, 2017, p. 214). }\end{array}$ & $\begin{array}{l}\text { O ensino que promove } \\
\text { comparações diretas entre o } \\
\text { objeto e o conceito que se } \\
\text { situa fora da compreensão de } \\
\text { que este é parte de um } \\
\text { sistema, volta-se à } \\
\text { valorização apenas das } \\
\text { observações } \\
\text { propriedades comuns dos } \\
\text { objetos, desenvolvendo nos } \\
\text { sujeitos mecanismos do } \\
\text { pensamento empírico- } \\
\text { classificador, que se } \\
\text { apresentam de modo } \\
\text { insuficiente para desenvolver } \\
\text { o pensamento teórico. }\end{array}$ \\
\hline $\begin{array}{l}\text { Utilização do relógio de } \\
\text { parede da sala de aula como } \\
\text { material de apoio para } \\
\text { observação e comparação do } \\
\text { movimento dos ponteiros, do } \\
\text { ritmo de cada um para marcar }\end{array}$ & $\begin{array}{l}\text { 1) Na base do conceito, } \\
\text { encontra-se a comparação } \\
\text { da multiplicidade sensorial } \\
\text { das coisas; 2) tal comparação } \\
\text { leva a a observar }\end{array}$ & $\begin{array}{l}\text { Reduz o conceito ao } \\
\text { empirismo presente no } \\
\text { pensamento } \\
\text { racionalista de tipo } \\
\text { empírico e classificador, que } \\
\text { finca suas raízes em }\end{array}$ \\
\hline
\end{tabular}




\begin{tabular}{|c|c|c|}
\hline $\begin{array}{l}\text { as horas, os minutos e os } \\
\text { segundos. } \\
\text { Contextualização do tema, } \\
\text { abordando o processo } \\
\text { histórico das transformações } \\
\text { inerentes ao objeto, bem } \\
\text { como o progresso na vida das } \\
\text { pessoas e nos modos de } \\
\text { organização das sociedades. }\end{array}$ & $\begin{array}{l}\text { características semelhantes, } \\
\text { comuns, dessas coisas; 3) a } \\
\text { fixação disso que é comum, } \\
\text { por meio da palavra, leva à } \\
\text { abstração como conteúdo do } \\
\text { conceito as } \\
\text { representações sensoriais } \\
\text { sobre essas características } \\
\text { externas constituem o } \\
\text { verdadeiro significado da } \\
\text { palavra -; } \quad \text { o) } \\
\text { estabelecimento } \\
\text { dependências de gênero e } \\
\text { espécie de tais conceitos - } \\
\text { segundo grau de } \\
\text { generalização dos traços - } \\
\text { constitui a tarefa fundamental } \\
\text { do pensamento, o que } \\
\text { interage regularmente com a } \\
\text { sensibilidade como sua fonte } \\
\text { (DAVIDOV, 2017, p. 216- } \\
217 \text { ). }\end{array}$ & $\begin{array}{l}\text { elementos aparentes, } \\
\text { valorizando as propriedades } \\
\text { externas e sensoriais dadas } \\
\text { pelo objeto. } \\
\text { (DAVIDOV, 2017). }\end{array}$ \\
\hline $\begin{array}{l}\text { Para crianças menores: } \\
\text { 1) aplicação de jogos para o } \\
\text { reconhecimento e a leitura de } \\
\text { horas; 2) pintura de desenhos } \\
\text { que retratam este objeto; 3) } \\
\text { construção de um relógio } \\
\text { individual para experimentar } \\
\text { a movimentação dos } \\
\text { ponteiros. } \\
\text { Para crianças maiores: } \\
\text { 1) aplicação de problemas } \\
\text { para que, em situações } \\
\text { comuns ao cotidiano, possam } \\
\text { calcular o tempo percorrido } \\
\text { entre uma atividade e outra } \\
\text { ou o tempo de duração de um }\end{array}$ & 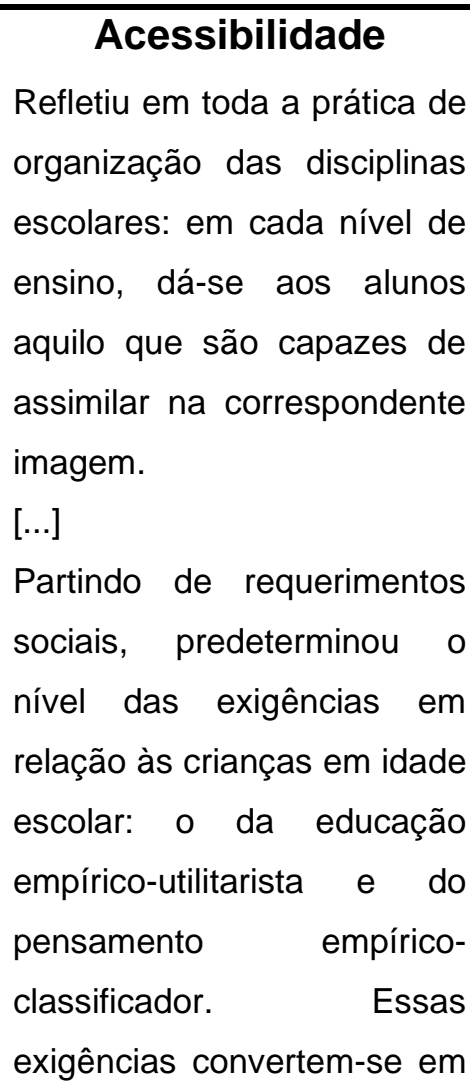 & $\begin{array}{l}\text { O aspecto limitante atrelado } \\
\text { às características evolutivas } \\
\text { da criança, além do } \\
\text { empobrecimento do ensino, } \\
\text { subestima as possibilidades } \\
\text { da criança de apropriar-se } \\
\text { dos elementos próprios do } \\
\text { desenvolvimento do } \\
\text { pensamento teórico, uma vez } \\
\text { que banalizam o verdadeiro } \\
\text { papel acerca do que a } \\
\text { educação representa para o } \\
\text { desenvolvimento humano } \\
\text { (DAVIDOV, 2017). }\end{array}$ \\
\hline
\end{tabular}




\begin{tabular}{|l|l|l|}
\hline evento; 2) elaboração de & possibilidades e normas do \\
novos problemas pelos & desenvolvimento psíquico da \\
estudantes, para que outros & criança, sancionadas pela \\
colegas de classe possam & autoridade da Psicologia \\
resolver. & $\begin{array}{l}\text { evolutiva e pela Didática } \\
\text { (DAVIDOV, 2017, p. 214- } \\
\text { 215). }\end{array}$ & \\
\hline
\end{tabular}

QUADRO 4. Síntese da análise de uma sequência didática para o ensino de medidas de tempo a partir dos princípios da escola tradicional analisados por Davidov (2017). Organizado pela autora.

Além dos aspectos relacionados aos princípios da escola tradicional apontados por Davidov (2017) e analisados inicialmente neste exemplo, neste movimento pudemos direcionar nosso olhar tanto para as tarefas organizadas pelo professor, como para as práticas e as condutas que se fizeram presentes desde o levantamento dos conhecimentos prévios, em uma conversa inicial, ao uso de instrumentos avaliativos que indicam, em seu aspecto geral, ações que se configuram como abertura e fechamento de uma sequência didática.

Para continuidade desta análise, recorremos a outros autores que se orientam pela teoria histórico-cultural, a fim de buscarmos subsídios que nos auxiliem a destacar que tanto a conversa inicial como a avaliação, na configuração apresentada pelo exemplo, colocam à margem a essência do que estas ações representam para o ensino. Evidencia-se, deste modo, a necessidade de que essas ações sejam qualificadas para que possam, de fato, ser compreendidas como ações a favor do desenvolvimento multilateral dos sujeitos.

Desse modo, em uma situação de ensino, a conversa inicial, necessariamente, deve estar a serviço da problematização de situações que brotem do cotidiano, no sentido de que estas se configurem como oportunidades que colocam os estudantes em situações em que possam vivenciar uma experiência semelhante àquela em que, em dado momento, levou a humanidade a buscar soluções para os problemas enfrentados. Assim, explicada por Moura et al. (2010) como uma situação desencadeadora, a conversa inicial, mais do que um resgate de conhecimentos prévios, deve 
explicitar a necessidade que levou a humanidade à construção do referido conceito, como foram aparecendo os problemas e as necessidades humanas em determinada atividade e como os homens foram elaborando as soluções ou sínteses no seu movimento lógicohistórico. (MOURA et al., 2010, p. 223)

Nessa perspectiva, a aproximação com o conceito não se dá pelo contato literário, em que este é apresentado ao estudante em uma "contação de histórias", proveniente de informações unicamente verbais dadas pelo professor, mas na vivência experimentada coletivamente por meio de situações pedagogicamente organizadas, que venham garantir aos estudantes verdadeiras possibilidades de apropriação dos conceitos cientificamente elaborados (MOURA et al., 2010).

Para o desenvolvimento dessas potencialidades, Moura et al. (2010) explicam o conceito de Atividade Orientadora de Ensino (AOE), em que, como núcleo do trabalho docente, recupera a estrutura da atividade proposta por Leontiev, indicando que, a partir de uma necessidade, constitui-se um motivo gerador de sentido que desencadeia objetivos e mobiliza, nos sujeitos, meios que os levem a satisfazer essa necessidade, mobilizando ações e operações que se revelam nessa satisfação.

$\mathrm{Na} A O E$, ambos, professor e estudante, são sujeitos em atividade e como sujeitos se constituem indivíduos portadores de conhecimentos, valores e afetividade, que estarão presentes no modo como realizarão as ações que tem por objetivo um conhecimento de qualidade nova. (MOURA et al., 2010, p. 2018)

Nesse sentido, a aproximação entre o estudante e o objeto de conhecimento a ser desvendado não passa do professor ao educando pela organização de uma conversa inicial, prescrita como requisito de uma boa situação de aprendizagem via explanação verbal, mas ocorre nas vivências, intencionalmente organizadas, que possibilitarão acesso singular aos processos constituintes da construção do pensamento teórico, concretizando "a apropriação da cultura no contexto da educação escolar" (MOURA et al., 2010, p. 220).

Os autores destacam ainda que a $\mathrm{AOE}$ se constrói na inter-relação professor e estudante, possibilitando a mediação da relação ensino- 
aprendizagem, que se constitui ao longo de todo processo de análise sobre "coincidência ou não entre os resultados atingidos por suas ações e os objetivos propostos" (MOURA et al., 2010, p. 220), o que para nós se configura na avaliação que, intrínseca à atividade humana, torna-se também, intrínseca à relação ensino-aprendizagem.

A avaliação, por sua vez, compreendida como parte integrante de todo 0 processo e não apenas como fim, torna-se ação inerente ao planejamento e à realização da atividade, de modo que, para além de instrumento verificador, seu papel configura-se como ação mediadora do processo educativo, concretizandose no movimento de análise e síntese que, ao passo que permite ao professor reorganizar e replanejar suas intervenções, revela-se como ação reguladora de seu próprio processo de aprendizagem, assim como para o estudante, em que se configura na regulação do seu próprio movimento de apropriação dos conceitos.

\begin{abstract}
A avaliação nesta perspectiva é assumida como mediadora entre a atividade de ensino elaborada pelo professor e a atividade de aprendizagem realizada pelo aluno, fornecendo elementos para esclarecer e orientar o processo de ensino e aprendizagem. (MORAES, 2008, p. 243)
\end{abstract}

Assim, ao configurar-se como ação intrínseca ao processo ensinoaprendizagem, a avaliação assume caráter mediador entre aquilo que o estudante sabe e aquilo que ele virá saber, enquanto realiza ações em colaboração com o outro, ou seja, enquanto é colocado em situações de ensino que, ao longo de sua jornada escolar, Ihe possibilitem apropriar-se dos modos do pensamento teórico. Sobre esta possibilidade, Vigotski (2001, p.329), explica que

a possibilidade maior ou menor de que a criança passe do que sabe fazer sozinha para o que sabe fazer em colaboração é o sintoma mais sensível que caracteriza a dinâmica do desenvolvimento e o êxito da criança. Tal possibilidade coincide perfeitamente com sua zona de desenvolvimento imediato.

Desse modo, assim como o êxito da criança não se configura em uma amostragem de respostas corretas que, equivocadamente, levam o professor a atribuir ao estudante a conquista da autonomia intelectual, uma vez que esta não 
se configura diretamente pela passagem do que o estudante fazia em colaboração para o que agora pode realizar sozinho, tal qual a apropriação da letra não torna o sujeito um bom escritor ou leitor e a apropriação do número não corresponde ao fim do ensino do conceito numérico, mas indica apenas que o processo do desenvolvimento do conceito está apenas começando (VIGOTSKI, 2001). A avaliação, por sua vez, deve ser assumida para além da instrumentalização pedagógica que quantifica as respostas dos estudantes e se situa como fechamento de um processo, apresentando-se como instrumento infalível de verificação da aprendizagem e da elaboração de futuras intervenções.

A avaliação, mais do que instrumento a favor da aprendizagem, precisa ser assumida como mediadora de todo o processo e relaciona-se não apenas à aprendizagem, mas estende-se também ao ensino, possibilitando, com isso, a regulação da atividade pedagógica, ao passo que medeia a mobilização de diferentes ações e operações que, para o professor, configuram-se na definição de procedimentos de como trabalhar com os conhecimentos teóricos e na utilização dos recursos metodológicos que contribuirão para o ensino e para o estudante, ao longo de todo processo de apropriação, mediando ações de resolução de problemas de aprendizagem, bem como a utilização de recursos metodológicos que o auxiliarão nessa aprendizagem (MOURA et al., 2010).

Para Moraes (2008), a avaliação é concebida na interdependência entre o ensino e a aprendizagem, revelando-se, nas ações do pensamento teórico, nas possibilidades de reflexão, de análise, de planificação teórica e de síntese, manifestando-se no cumprimento da real função do ensino escolarizado, o que, para Moura et al. (2010), objetiva-se na concretização do processo entre a atividade de ensino do professor e a atividade de aprendizagem do estudante.

Portanto, entendemos que a avaliação, como um recurso metodológico de uma ação consciente do professor, ao ser assumida como um instrumento de fechamento do processo, deve receber o valor correspondente ao lugar que ocupa. Lugar este que não pode ser maior do que aquele que ocupa a avaliação, objetivada como instrumento simbólico do pensamento, qualificada como mediadora do processo de desenvolvimento das potencialidades dos sujeitos, revelando-se como ação intrínseca ao movimento de ensino e aprendizagem 
que, para o professor e para o estudante, concretiza-se na elaboração de uma atividade educativa que promova a apropriação da herança cultural.

Para aprofundarmos nossa análise em relação ao papel da avaliação, a seguir, nós a apresentaremos sob a ótica que a compreende em sua dimensão instrumental e operacional, que para nós a representa de modo desvinculado da ação pedagógica.

Para contrapor-se a essa posição, apresentaremos também a avaliação em sua dimensão dialética, destacando o modo como, sob essa perspectiva, ela passa de instrumento externo para instrumento intrínseco à atividade dos sujeitos envolvidos na relação ensino-aprendizagem. 


\section{ALGUMAS DIMENSÕES DA AVALIAÇÃO: DA PSEUDOINTENCIONALIDADE PEDAGÓGICA À FORMAÇÃO DA CONSCIÊNCIA DOCENTE}

Assim como discutimos anteriormente, a popularização dos ambientes formais de educação, em decorrência da implementação de políticas públicas voltadas à aproximação da população ao saber escolarizado, ao passo que, "garantiu" direitos de acesso e permanência desses sujeitos, objetivando minimizar as desigualdades por meio da formação do cidadão e da qualificação para o trabalho, de acordo com Moraes (2008), contribuiu tanto para aqueles que ocupavam esses espaços quanto para que a sociedade absorvesse a concepção mercadológica, associando seus instrumentos à aplicação na escola como indicadores da qualidade do ensino e da aprendizagem.

Essa organização, ao alinhar-se aos interesses de um grupo que coloca na escola, como a conhecemos, o objetivo de manter a produção e garantir a "existência humana fundamentada na apropriação privada de bens" (MORAES, 2008, p.43), desencadeia um ensino, cujo entendimento de autonomia intelectual se dá pelo desenvolvimento de habilidades voltadas à resolução de problemas comuns no cotidiano, que, assim como explica Davidov (2017), com a intenção de torná-lo acessível, fazem com que o conhecimento científico, nesses moldes, configure-se como supérfluo e tenha seu espaço substituído pelo conhecimento prático que, em sua essência efêmera e imediata, melhor corresponde ao mundo do trabalho.

Nesse movimento, as diretivas educacionais, assim como já analisamos aqui, modelam a cultura escolar e promovem, desde a normatização do currículo, às práticas e às condutas que se revelam nos modos de organização do trabalho da escola como um todo, lugar em que a avaliação, em suas diversas facetas, é legitimada como instrumento infalível para aferir a qualidade da aprendizagem atual, apontando os saberes dos estudantes e também como principal fonte de análise do trabalho desenvolvido e do planejamento de futuras intervenções (FREITAS, 2013).

O uso habitualmente instrumental dessa avaliação desconsidera a probabilidade de, por trás de sua aparente infalibilidade, apresentar "um processo passível de erros e de análises incompletas" (FREITAS, 2013, p. 1155), 
que não correspondem à plenitude das possibilidades de desenvolvimento dos sujeitos que, singulares ao processo ensino-aprendizagem, são ocultadas pela lógica pautada na mensuração, na quantificação e na classificação, trazendo à luz apenas aquilo que os sujeitos realizam sozinhos, em detrimento do que poderiam realizar com o auxílio de parceiros mais experientes, ignorando a tese de que "o ensino seria totalmente desnecessário se pudesse utilizar apenas 0 que está maduro no desenvolvimento" (VIGOTSKI, 2001, p.334).

Diante disto, neste capítulo, nosso objetivo centra-se em analisar três facetas da avaliação, denominadas por nós como "dimensão instrumental", "dimensão operacional" e "dimensão dialética". Para isso, organizamos o capítulo em cinco subitens: nos dois primeiros, com base no referencial teórico que assumimos, discutiremos as características que configuram a avaliação em sua dimensão instrumental e operacional. No terceiro subitem, analisaremos alguns dos materiais utilizados pela Secretaria Municipal de Educação do município campo, no qual previam possibilidades de monitoramento das aprendizagens dos estudantes. No quarto subitem, avançaremos para análise da avaliação em sua dimensão dialética e, por fim, no quinto subitem, trataremos de uma circunstância em que a avaliação, na dimensão a qual temos defendido, possibilita as condições objetivas para organização do ensino, fazendo um adendo às necessidades impostas pelo ensino remoto ${ }^{5}$.

Para finalizar, discutiremos em que medida a dimensão dialética da avaliação pode materializar-se como ação inerente à atividade de ensino e de aprendizagem, uma vez que permite ao professor condições objetivas para organizar o ensino que mobilize no estudante o desenvolvimento de sua atividade e possibilite a ambos desenvolver-se, por meio da apropriação do conhecimento humano mediatizado pelas vivências que constroem como parceiros sociais, mesmo que em distanciamento.

\footnotetext{
${ }^{5}$ As secretarias municipais e estaduais de ensino, em conformidade com o Decreto $n^{\circ} 40.550$, de 23 de março de 2020 que, fixava como medida para enfrentamento da emergência de saúde pública de importância internacional decorrente do novo coronavírus, determinam como aplicação de medidas de distanciamento social, a suspensão das aulas presenciais, aderiram, de modo geral, o ensino em modalidade remota.
} 


\subsection{A dimensão instrumental da avaliação}

Os modelos avaliativos que utilizam a aplicação de exames em larga escala, atrelando seus índices à aprendizagem dos estudantes, a exemplo dos movimentos educacionais internacionais, chegaram ao Brasil com a finalidade de atender a necessidade emergente do novo ciclo educacional em que o País, após a Constituição de 1988, buscava fixar políticas públicas com objetivo de democratizar o ensino fundamental e expandir o ensino médio, desencadeando um senso de urgência em monitorar o desempenho educacional, bem como diagnosticar e apontar as necessidades e a qualidade dos sistemas educacionais como um todo (FERNANDES; GREMAUD, 2009).

$\mathrm{Na}$ década de 90, na gestão do Ministro da Educação Paulo Renato Souza, no governo de Fernando Henrique Cardoso, o Exame Nacional do Ensino Médio (ENEM), como exemplo de aplicação desse instrumento, teve sua primeira versão, com o objetivo de avaliar o aprendizado dos estudantes do ensino médio em todo o país, para auxiliar o Ministério da Educação na elaboração de políticas pontuais e estruturais para melhoria da qualidade do ensino (CASTRO; TIEZZI, 2004).

Desde então, avaliações dos sistemas de ensino em escala estadual e federal, bem como o tratamento dos seus resultados, têm ganhado corpo diante da organização da educação brasileira, chegando às escolas e ao interior delas, sob a roupagem de nomenclaturas (diagnóstica, formativa, processual, somativa, mediadora) que, incorporadas à cultura escolar ao longo de décadas de "formação" docente, conquistaram espaço no que se refere à utilização da avaliação como instrumento orientador do planejamento de futuras ações e intervenções pedagógicas e como instrumento indicador das conquistas intelectuais dos estudantes, caracterizando-se como principal, se não, única fonte de análise da relação ensino-aprendizagem (FREITAS, 2013).

Esse modo de conceber a avaliação, segundo Hoffmann (1992), opõe-se ao modelo "transferir-verificar-registrar", em que, estreitamente relacionado à origem etimológica da palavra (do latim a + valere, que significa atribuir valor e mérito) transferia às práticas avaliativas apenas a lógica da mensuração, fazendo do ato de avaliar um mero reprodutor de mecanismos classificatórios (KRAEMER, 2005), que acarretavam altos índices de reprovação, derivando, 
logo nos primeiros anos do ensino fundamental, também em altos índices de evasão (LEON; MENEZES-FILHO, 2002).

Para Hoffmann (1992), que discute a avaliação mediadora, criar condições para que, no espaço escolar e para o trabalhador da educação, esse instrumento configure-se como contrário à perspectiva excludente, o caminho é assumi-lo como instrumento de acompanhamento reflexivo e dialógico, em que a avaliação de caráter segregacional é suprimida, ao passo que se evidenciam os "saberes" conquistados, em detrimento dos "erros" cometidos pelos estudantes, atribuindo-se a eles um novo status na relação ensinoaprendizagem. Em outras palavras, o erro passa a ser compreendido como um terreno fértil e fecundo para o cultivo do conhecimento pelos sujeitos, pois, pela ação reflexiva e dialógica sobre esse terreno, o professor teria condições de possibilitar, para si e para o estudante, a superação das dificuldades e o enriquecimento dos seus saberes.

\begin{abstract}
A avaliação, enquanto relação dialógica, vai conceber o conhecimento como apropriação do saber pelo aluno e também pelo professor, como ação-reflexão-ação que se passa na sala de aula em direção a um saber aprimorado, enriquecido, carregado de significados, de compreensão. (HOFFMANN, 1992, p. 51)
\end{abstract}

Para nosso estudo, é importante ressaltarmos que, apesar da semelhança sonora existente entre os termos "dialógico" e "dialético", há diferenças que necessitam ser destacadas para auxiliar-nos a compreender os conceitos que envolvem a "avaliação mediadora" defendida por Hoffmann (1992) e a avaliação como "unidade mediadora intrínseca à relação ensino-aprendizagem", como temos defendido.

O termo "dialógico", explicado de acordo com a teoria bakhtiniana, segundo Pires (2002), grosso modo, surge como fundamento de toda a linguagem, constituindo e transformando o sujeito, não como reprodução do meio, mas como "palavra enunciada", em resposta a algo ou alguém, em que o sentido do discurso configura-se como possibilidade infinita de interpretação, ou seja, é uma "possibilidade sem fim de sentidos esquecidos que voltam à memória, provocando neles a renovação dentro de outros contextos" (PIRES, 2002, p. 42). 
Portanto, assumir a avaliação enquanto "relação dialógica" (HOFFMANN, 1992, p. 51) significa tratar do instrumento de avaliação e de seus resultados, como possibilidade de infinitas interpretações da capacidade de apropriação dos conteúdos pelos estudantes, uma vez que, como instrumento, adequa-se às necessidades de quem o opera. Isto pode direcioná-lo tanto ao diagnóstico dos saberes quanto à verificação da qualidade do processo de aprendizagem.

Por outro lado, o termo "dialético", de acordo com Vigotski (2003, p.203), do ponto de vista do desenvolvimento infantil, relaciona-se ao desenvolvimento de contradições,

\begin{abstract}
em que o comportamento vai se formando sob a influência da ação sistemática do ambiente e também com relação a vários ciclos ou períodos da evolução do próprio organismo infantil, que por sua vez, determinam a relação do ser humano com o meio. A criança se desenvolve de modo desigual, paulatino, pela acumulação de pequenas mudanças, mas também aos empurrões, aos saltos, de maneira ondulatória; dessa forma, os períodos do auge do crescimento são acompanhados de períodos de estagnação e abatimento.
\end{abstract}

Desse modo, a concepção dialética deve ser explicada como a que está presente no conceito de zona de desenvolvimento proximal (VIGOTSKI, 2001) que, para nós, pode ser compreendida como a possibilidade de transformação intrapsíquica, por meio da mediação interpsíquica, uma vez que ela "constitui-se parte inerente do planejamento e da realização da atividade, tendo em vista que essa se concretiza no processo de análise e síntese na relação entre a atividade de ensino do professor e a atividade de aprendizagem do estudante" (MOURA et al., 2010, p. 224).

Assim, o que diferencia a avaliação mediadora apresentada por Hoffmann daquela que temos defendido, é que, para nós, a avaliação se constitui não apenas como material concreto, permeado por infinitas interpretações, mas também como elemento simbólico que, mediado externamente (na relação interpsíquica), constitui-se internamente (na relação intrapsíquica) como unidade mediadora, possibilitando a apropriação da produção humana existente, ao passo que impulsiona o desenvolvimento de um tipo especial de pensamento, 0 teórico, que instrumentaliza os sujeitos para que, mais do que exercer uma profissão e viver em sociedade, possam desenvolver em si as máximas capacidades humanas. Nesse movimento, ao passo que se apropriam dos nexos 
do pensamento teórico, apropriam-se também dos conhecimentos construídos historicamente pela humanidade.

A concepção apresentada por Hoffmann (1992), ao atrelar a diversidade de interpretações aos resultados e modos de aplicação do instrumentos voltados à verificação e ao acompanhamento da aprendizagem, na busca por alinhar o planejamento do professor em relação às suas práticas e condutas, revela-se no atual documento referencial da educação brasileira, sob a premissa do "compromisso com a educação integral", em que se aborda a avaliação do aprendizado como pressuposto para promoção de bons resultados (BRASIL, 2017).

Os efeitos dessa premissa manifestam-se em diferentes instâncias, legitimando ao instrumento avaliativo a máxima confiabilidade em relação à aprendizagem dos estudantes. Além disso, permite que seus resultados sejam considerados como reflexo direto do trabalho de um ou de outro professor, bem como de um ou de outro estudante (MORAES, 2008; FREITAS, 2014).

Moraes (2008) explica que, nesta configuração, a avaliação, cuja aplicação assume caráter comprobatório da aprendizagem, coloca-se sobre os sujeitos e sobre a relação ensino-aprendizagem, a responsabilidade imediata, em que se atribui ao professor e ao estudante o certificado pelo bom trabalho desenvolvido quando os índices são altos ou a culpa pelo insuficiente trabalho realizado quando os índices são baixos.

\footnotetext{
Nesta perspectiva, o conhecimento é transmitido de forma estática e fragmentado em áreas de conhecimento, em que a avaliação tende a confirmar a capacidade ou não do indivíduo de apropriar-se deste conhecimento. Entretanto esta apropriação, necessariamente, não significa agir, refletir, atuar sobre o conhecimento, mas simplesmente reproduzi-lo mecanicamente. Esta prática avaliativa está estreitamente ligada com as formas de relações sociais estabelecidas pela sociedade capitalista, em que se responsabilizam o indivíduo pelo seu sucesso e fracasso tanto escolar quanto social. (MORAES, 2008, p. 28)
}

Para além dos muros escolares, esses efeitos, assim como explica Moraes (2008), se materializam em menções que chegam à sociedade sob a forma de pseudoindicadores que ora apontam para "capacidade" dos estudantes, ora para a "qualidade" do trabalho desenvolvido pelos professores.

Nesse sentido, compreendemos que tal relação, equivocadamente, conduz ao entendimento que considera como processos equivalentes a 
avaliação da aprendizagem e a avaliação da relação ensino-aprendizagem, desconsiderando a essência que as fundamenta. Enquanto na primeira configura-se como subsídio para ação docente apenas o conhecimento retrospectivo do estudante, ou seja, aquele que se encontra amadurecido e consolidado no nível de desenvolvimento real, a segunda, por sua vez, liga-se aos sujeitos da relação, principalmente, como possibilidade de avaliação da atividade de ensino que, organizada intencionalmente, possibilitará o desenvolvimento das funções psicológicas que ainda não amadureceram, mas que se encontram "no amanhã do desenvolvimento" (VIGOTSKI, 2001, p. 333).

Freitas (2013), que também discute os efeitos decorrentes da legitimação da equivalência entre a avaliação da aprendizagem e a avaliação da relação ensino-aprendizagem, afirma que esta correlação suscita uma percepção restrita que conecta os resultados das avaliações unicamente ao que se produz nas escolas, como se o resultado da relação ensino-aprendizagem se concretizasse na fabricação de sujeitos escolarizados capazes de transpor o aprendido em ambiente escolar diretamente ao meio social, excluindo-se qualquer vinculação entre as múltiplas determinações que, de modo direto e indireto, constituem a dinamicidade da relação ensino-aprendizagem.

De acordo com a tese vigotskiana de desenvolvimento ${ }^{6}$, essas avaliações, ao passo que apontam somente para aquele conhecimento já amadurecido e consolidado, além de representarem a equivocada compreensão que relaciona o maior número de respostas corretas à aparente conquista da autonomia intelectual, isolam da relação ensino-aprendizagem os nexos construídos por meio das vivências desses sujeitos nos diferentes espaços sociais que ocupam e dos quais fazem parte, uma vez que desconsideram que, assim como "qualquer inventor, por mais genial que seja, é sempre produto de seu ambiente e de sua época" (VIGOTSKI, 2014, p. 32), a aprendizagem escolar decorrente de situações intencionalmente organizadas para este fim configura-se como "um processo histórico contínuo, onde cada nova forma tem por base a precedente" (VIGOTSKI, 2014, p. 32).

Para exemplificarmos esta relação, recorremos à analogia feita por Vigotski (2014), na qual o autor explica que o desenvolvimento da imaginação

\footnotetext{
${ }^{6}$ Em que o autor explica sobre o nível de desenvolvimento atual, a zona desenvolvimento proximal e nível de desenvolvimento potencial (VIGOTSKI, 2001, 2007).
} 
criativa pode ser compreendido a partir do movimento humano que envolve 0 nascimento de uma criança: aquilo que chamamos de criação, neste caso, pode ser compreendido como o próprio nascimento, ou seja, assim como nascer decorre de um processo interno de gestação e desenvolvimento fetal, a criação representa o ponto culminante do processo imaginativo.

Partindo desta analogia, compreendemos que a aprendizagem não decorre apenas de um único momento da vida dos sujeitos, mas de um longo processo de desenvolvimento humano, que tem sua gênese anterior à chegada da criança à escola, pois inicia assim que ela vivencia, desde seu nascimento, os primeiros contatos com parceiros mais experientes.

É natural que a aprendizagem pré-escolar seja substantivamente
diversa da escolar, pois esta trabalha com a assimilação das bases do
conhecimento científico. Mas mesmo quando a criança, ao se
encontrar no perigo das primeiras perguntas, assimila os nomes dos
objetos ao redor, no fundo ela passa por um determinado ciclo de
aprendizagem. Assim a aprendizagem e o desenvolvimento não se
encontram pela primeira vez na idade escolar, mas estão de fato
interligados desde o primeiro dia de vida da criança. (VIGOSTSKI,
2010 , p. 477)

Em síntese, ao analisar como sinônimos os índices das avaliações, a aprendizagem dos escolares, o trabalho desenvolvido pelos professores, bem como as múltiplas determinações que compõem o processo ensinoaprendizagem, em primeiro plano, incita-se um movimento de responsabilização individual que isola do desempenho final dos estudantes os fatores que cingem a relação entre sujeitos e seu entorno social, bem como as condições de estudo que envolvem a atividade estudantil e as condições de trabalho, que orientam a atividade docente.

Em segundo plano, induzem à perda da influência das políticas públicas sobre esses resultados, sob o pretexto de que, para elas, positivos ou negativos, os dados levantados caracterizam-se como indicadores do cumprimento (ou não) das propostas advindas dos referenciais norteadores da educação brasileira. Nesta configuração, suaviza-se seu caráter responsabilizador, ao passo que a avaliação é assumida como instrumento de análise para implementação de novas medidas que discursam sobre a melhoria dos sistemas educacionais (FREITAS, 2013). 
Por conseguinte, discutir a forma como esse processo tem sido brandamente absorvido leva-nos a analisar a avaliação da aprendizagem como instrumento orientador do trabalho pedagógico, pois, além de modelar a opinião da sociedade acerca da tríade sujeito-cultura-desenvolvimento, contribui para a compreensão do docente sobre o papel daqueles que estão diretamente envolvidos na relação ensino-aprendizagem, e também sobre o lugar que esses ocupam na organização do ensino e das práticas pedagógicas. Isso porque a avaliação, na perspectiva da teoria histórico-cultural, fundamentada na Atividade Orientadora de Ensino, realiza-se como atividade não apenas na dimensão orientadora da atividade docente, mas na dimensão mobilizadora da atividade de aprendizagem.

Nesse sentido, ao passo que a avaliação se ocupa da aprendizagem e volta-se para a verificação dos saberes dos estudantes e para o planejamento de futuras ações que miram $o$ avanço da aprendizagem, mesmo que para 0 professor esse instrumento assuma caráter diagnóstico, processual ou formativo, a intenção atribuída a ele não se configura como fortemente capaz de colocar à margem seu caráter excludente, classificatório e responsabilizador inerente ao instrumento avaliativo, pois, para além da ferramenta de registro, o instrumento liga-se à prática avaliativa; e essa centraliza a reflexão sobre a atitude particular dos sujeitos, preconizando a exaltação das capacidades individuais (MORAES, 2008) e a conservação da hierarquia social, refletida, nesta relação, no papel do avaliador e do avaliado.

Há ainda que se considerar o desenvolvimento de habilidades voltadas a saberes laborais que permitem aos sujeitos o desenvolvimento apenas daquelas competências que conservam o ideal educacional capitalista (MORAES, 2008), mantendo uma matriz formativa ancorada na capacidade de responder a testes como meio para acompanhar a aprendizagem do estudante e o trabalho do professor. Assim, quanto mais habilidoso o estudante, maior o indicativo de que seu professor tem cumprido com as propostas dos referenciais, o que, não necessariamente, corresponde à consolidação da relação ensino-aprendizagem.

Em outras palavras, para melhor elucidarmos este ponto, recorremos ao que Freire (1987) denomina por "educação bancária". A tônica dessa perspectiva configura-se no ato de "encher" os estudantes de uma narrativa que compõe conteúdos aquém daqueles que são frutos do desenvolvimento histórico da 
humanidade, mas são retalhos de uma realidade desconectada, cuja visão de educação engendra-se na formação de sujeitos caracterizados por títulos que os definem como "o melhor educador", aquele que mais enche seus estudantes com conteúdos, assim como "o melhor educando" corresponde àquele que mais se deixa encher, sem protestar.

Para Freire (1987), este modelo educacional corresponde ao ato de depositar, de modo que os sujeitos se revelam como articulações de um mecanismo em que os estudantes são considerados depositários, enquanto os educadores são os depositantes. Assim, tanto um como outro "se arquivam na medida em que, nesta destorcida visão da educação, não há criatividade, não há transformação, não há saber" (FREIRE, 1987, p. 38), mas ocorre a conservação de moldes que "formam" sujeitos acríticos de sua própria humanização, uma vez que essa se concretiza via formação escolarizada por meio de princípios que regem a formação do homem individualista, que se orienta para 0 desenvolvimento baseado na competência e no mérito, comprovados por instrumentos avaliativos (FREIRE, 1987).

Daí que um dos seus objetivos fundamentais [deste modelo educacional], mesmo que dele não estejam advertidos muitos do que a realizam, seja dificultar, em tudo, o pensar autêntico. Nas aulas verbalistas, nos métodos de avaliação dos "conhecimentos", no chamado "controle de leitura", na distância entre o educador e os educandos, nos critérios de promoção, na indicação bibliográfica, em tudo, há, sempre a conotação "digestiva" e a proibição ao pensar verdadeiro. (FREIRE, 1987, p. 41, grifos do autor)

Nesta configuração, em que a avaliação é assumida pelos professores como instrumento de análise da aprendizagem, o pensar autêntico, que possibilita e permite aos sujeitos o salto qualitativo no desenvolvimento, impulsionando-os do conhecimento empírico ao teórico, é minorado à ótica que leva em conta apenas aquilo que a criança consegue realizar sem auxílio, ou seja, aquilo que se encontra em seu nível de desenvolvimento atual (VIGOSTKI, 2001).

Azevedo (2005) relaciona a "educação bancária" de Freire à avaliação que busca quantificar a aprendizagem dos estudantes, denominando-a como "avaliação bancária", e, com isto, fazemos desta analogia um amparo para destacar que as atuais nomenclaturas que envolvem os instrumentos avaliativos 
inseridos na cultura escolar e legitimados como irrefutáveis fontes de análise e organização da atividade docente, ao passo que ocupam o lugar de "testes de conquistas escolares, nunca refletem a marcha real do desenvolvimento da criança" (VIGOSTKI, 2010, p. 487), pois, ao apontarem para o ontem, pouco contribuem para que os sujeitos possam se apropriar das potencialidades que levam ao desenvolvimento.

Desse modo, assumir que o domínio do sistema alfabético, das habilidades escritoras ou leitoras, bem como das operações básicas da matemática, em que o ensino se volta à resolução de cálculos ou à leitura de horas em relógios de ponteiros, não se constituem como reflexo da conquista da autonomia intelectual dos escolares - primeiro porque esse processo ocorre ao longo de toda existência dos sujeitos, caminhando para além de sua vida escolar. Segundo, porque o que a criança realiza em parceria com outro revela muito mais do dinamismo do seu desenvolvimento do que de sua realização individual, pois, ao "determinar para nós o amanhã da criança, o estado dinâmico do seu desenvolvimento que leva em conta não só o já atingido mas também o que se encontra em processo de amadurecimento" (VIGOSTKI, 2010, p. 480), é que, verdadeiramente, conduzirá a atividade docente e isso, dificilmente, poderá ser mensurado por instrumentos estáticos.

Nesse sentido, compreendemos que a mudança que configura a avaliação como ação mediadora da relação ensino-aprendizagem não está na alteração das nomenclaturas que acompanham os instrumentos ou a pseudointencionalidade atribuída eles, mas vincula-se aos métodos de ensino que, ao adquirirem nova qualidade, revelam que o papel da escola não está na formação do cidadão ou em sua qualificação para o trabalho, mas na formação humana que permite ao homem humanizar-se.

E este o faz, à medida que, para além do direito à aprendizagem, apropriase do direito à educação por meio de situações intencionalmente organizadas que possibilitam que a cultura construída pelas gerações precedentes faça parte da vida de todos.

Compreendemos, com isto, que este é o papel da educação escolar para com a criança: "envidar todos os esforços e fazê-la avançar nessa direção, desenvolver nela aquilo que em si não está suficientemente desenvolvido" (VIGOSTKI, 2010, p. 481), levando-a a tornar-se um sujeito dialético que, para 
além da adaptação à sociedade, tem em mãos condições de transformá-la, ao transformar-se.

Em continuidade a essa discussão, abordaremos a seguir a dimensão operacional dos instrumentos avaliativos que, naturalizados ao longo dos anos, foram incorporados à cultura escolar e passaram a ser compreendidos como principais recursos didáticos no que se refere à verificação dos saberes e à validação da conquista da autonomia intelectual. Nessa direção, abordaremos a operacionalização destes instrumentos sob a égide do acompanhamento pedagógico, discutindo em que medida revelam (ou não) as peculiaridades da potencialidade humana para, de fato, contribuir para organização do ensino, em especial, o ensino da Matemática.

\subsection{A dimensão operacional da avaliação}

A análise da avaliação em sua dimensão instrumental trouxe à luz questões que se situam para além da naturalização dos instrumentos de avaliação que, incorporados ao ensino pela lógica mercadológica (MORAES, 2008), constituíram-se como "meio infalível" para validação das aprendizagens conquistadas pelos estudantes (FREITAS, 2013).

Sob a égide do acompanhamento da qualidade, esses instrumentos que foram caracterizados por diferentes nomenclaturas para que possibilitassem melhor aceitação pelos sujeitos, passaram a ser operacionalizados em momentos pontuais e servem simultaneamente ao que, nas palavras de Freitas (2014, p. 1088), se refere ao "fechamento do processo ou verificação da qualidade do processo ocorrido", indicando, àqueles que dirigem a educação, o cumprimento das diretivas; e àqueles que a colocam em prática, a assimilação dos conteúdos por parte dos escolares.

Nesse sentido, essas estratégias de monitoramento voltaram-se não apenas à organização do conteúdo curricular, mas, sobretudo, aos modos que orientam sua aplicação, desencadeando uma dinâmica de modulação das práticas e das condutas dos profissionais da educação (FREITAS, 2014) que, de tal modo, traz em sua gênese a uniformização do ensino, alinhando-se ao que Freire (1987) discute acerca da relação ensino-aprendizagem sob a ótica da "educação bancária". Esta, por sua vez, leva o professor a atuar como 
depositante, enchendo os escolares com conteúdos "verbosos e palavrescos", ao passo que sua prática se organiza para o ensino daquilo que será avaliado. E os estudantes, em lugar de depositários, têm sua atividade de estudo substituída pelo recebimento acrítico de "falsos comunicados", predominantemente, assumidos como verdadeiros saberes.

Essa dinâmica induz à modulação dos sujeitos, levando-os à adaptação que conserva as características vigentes da sociedade capitalista (MORAES, 2008), na qual os modelos avaliativos são inseridos e mantidos nas escolas sob o caráter mandatário dos referenciais. Ali podemos observar a equalização da função social do ensino ao desenvolvimento de competências afiguradas como fundamentais para a qualidade da aprendizagem na formação do cidadão, mas que, assim como discutimos, se diferenciam do desenvolvimento das potencialidades dos sujeitos, as quais consideramos indispensáveis para 0 desenvolvimento humano.

Sobre esses modelos, Sousa (2014) aborda a questão dos índices de desempenho e rendimento dos estudantes brasileiros em avaliações em larga escala como recurso para manutenção desse sistema, assim como Ravitch (2010), que analisa os prejuízos da incorporação dos objetivos de accountability ${ }^{7}$ na educação estadunidense, apontando que a comum associação entre o alcance de metas e a melhoria da qualidade da educação, em vez de aumentar as possibilidades de apropriação dos nexos próprios do desenvolvimento do pensamento teórico, incentiva as escolas e seus professores a ensinar habilidades para a aprendizagem voltada à resolução de testes e, ainda, a buscar e aplicar outras maneiras de alcançar as metas que, não necessariamente, garantem a melhoria da qualidade da aprendizagem e do ensino.

Entendemos que tal organização conduz a uma avaliação cuja concepção, assim como apresentamos em analogia ao ensino bancário discutido

\footnotetext{
${ }^{7}$ O termo accountability, de origem inglesa e sem tradução exata para o português, está presente na literatura americana desde antes da década de 1970. No Brasil, foi introduzido no início dos anos de 1990, justamente quando se instalava no país o regime democrático de administração pública. Assim, seu ingresso no contexto das políticas nacionais coincide com o discurso da descentralização, da desconcentração dos serviços públicos e da autonomia dos entes federados, ainda que com princípios distintos e consequências diversas. [...] um modelo abrangente de accountability inclui a prestação de contas, a responsabilização e a avaliação como partes integradas e integráveis de um projeto nacional (NARDI; SCHNEIDER, 2012, p. 14).
} 
por Freire (1987), enaltece a capacidade individual e reduz a aprendizagem à reprodução fabril de conteúdos escolares, alavancando a equivocada compreensão de que desenvolvimento, tal qual aprendizagem, corresponde ao maior número de respostas corretas como amostra representativa da conquista da autonomia intelectual. Assim, intensifica a responsabilização dos sujeitos, ao passo que atribui ao mérito a responsabilidade individual pela conquista ou pelo fracasso escolar. E, então, a meritocracia encontra-se legitimada.

Para fundamentarmos essa discussão buscamos o que Vigotski (2010) explica sobre o desenvolvimento mental da criança em idade escolar: ele destaca os equívocos das abordagens que tratam de aprendizagem e desenvolvimento como processos similares que se constroem estruturalmente; desmistifica e explica que, assim como a criança não necessita estar desenvolvida para aprender, ambos os processos, apesar de inerentes ao intrincado movimento de humanização, não são sinônimos para o mesmo movimento interno, assim como não se seguem a reboque, ou seja, para os fundamentos da teoria histórico-cultural, aprendizagem e desenvolvimento são compreendidos como processos singulares, em que a aprendizagem pode levar ao desenvolvimento das funções psíquicas superiores da criança, revelando-se em um processo de desenvolvimento sumamente original:

\footnotetext{
Aprendizagem não é desenvolvimento mas, corretamente organizada, conduz o desenvolvimento mental da criança, suscita para a vida uma série de processos que, fora da aprendizagem se tornariam inteiramente inviáveis. Assim, a aprendizagem é um momento interiormente indispensável e universal no processo de desenvolvimento de peculiaridades não naturais mas históricas do homem na criança. (VIGOTSKI, 2010, p. 484)
}

Desse modo, a relação ensino-aprendizagem, organizada para possibilitar a apropriação da cultura humana necessariamente deve estar voltada a ações que se orientam para o amanhã, em que o conhecimento, como uma semente plantada, necessita que o jardineiro a cultive diariamente, regando e adubando, para que no momento oportuno venha a florescer (VIGOSTSKI, 2001).

Nesse sentido, a perspectiva que aborda a operacionalização pontual da avaliação que, inerente ao instrumento avaliativo, aponta para o ontem, revela somente aquele conhecimento já consolidado. Em outro sentido, a avaliação 
para o amanhã configura-se como unidade dinâmica e intrínseca à atividade humana, mediando as possibilidades de desenvolvimento e revelando-se na relação ensino-aprendizagem do mesmo modo como o desabrochar da flor ocorre na atividade do jardineiro, que, ao cuidar de seu jardim, regula a quantidade de água e adubo, e não apenas se orienta pelo processo natural de desenvolvimento da semente, mas analisa atentamente a relação entre ela, o solo, o ambiente e seus cuidados (VIGOTSKI, 2003).

Desse modo, assim como a avaliação para o amanhã pode representar muito mais potencialidade, ao revelar aquilo que o estudante tem condições de vir a fazer em parceria com sujeitos mais experientes, compreendemos que considerar a conquista da autonomia intelectual como resultado do mérito pessoal corresponde à negação da coletividade presente na relação ensinoaprendizagem, que ocorre com a "interação e inter-relações das pessoas, mediadas pelos fins, tarefas e valores da atividade comum, o que vale dizer, por seu verdadeiro conteúdo" (PETROVSKI, 1984, p. 37, tradução nossa).

Nessa direção, para a teoria histórico-cultural, a relação ensinoaprendizagem, na atividade pedagógica, assume papel de unidade dialética entre o ensino e a aprendizagem, revelando-se em "resposta à satisfação das necessidades que se impõem ao homem em sua relação com o meio em que vive" (RIGON; ASBAR; MORETTI, 2017, p. 74), qualificando-a, não como único, mas principal caminho para apropriação dos conhecimentos científicos.

Portanto, a avaliação para o amanhã, evidenciada na atividade pedagógica como intrínseca à atividade humana, supera os limites da avaliação pontual que, em sua dimensão operacional, restringe-se àqueles "saberes" denominados por Vigotski (2001), em sua analogia: não às flores ou frutos, mas aos brotos do desenvolvimento que, por sua vez, possuem um longo percurso a percorrer até chegar a florescer.

Diante desta compreensão, uma vez que a BNCC tem se configurado diretamente como documento orientador da relação ensino-aprendizagem, assumindo indispensável função no processo de nova organização dos currículos, colocamo-nos a questionar acerca de quais princípios revelariam as práticas avaliativas apreendidas por este referencial e em que medida estas práticas se configurariam como modeladoras das condutas dos profissionais da educação? 
Em resposta a esses questionamentos, revisitamos o documento da Base, na busca por analisar aquilo que seus princípios revelam sobre a avaliação presente na relação ensino-aprendizagem a partir do modelo educacional em vigência.

Essa dinâmica nos permitiu destacar que, para esse referencial, a avaliação configura-se como instrumento aliado às possibilidades de alavancar o processo educativo, caracterizando-se como instrumento responsável por validar sua qualidade e configurando-se como principal requisito para 0 desenvolvimento e a conquista de bons resultados que, em suma, garantiriam uma educação capaz de "firmar valores e estimular ações que contribuam para a transformação da sociedade" (BRASIL, 2017, p. 8). Mas qual sociedade?

Explicitar esses princípios enseja conceber que o ato educativo mediado por "instrumentos avaliativos operacionalizados adequadamente" não apenas contribui para acompanhar a qualidade do ensino e da aprendizagem dos estudantes, mas também para planejar futuras intervenções pedagógicas e subsidiar a elaboração de informes empíricos para a sociedade sobre a qualidade dos sistemas educacionais e para implementar políticas de monitoramento de habilidades e competências que, em linhas gerais, beneficiariam a transformação da sociedade como um todo.

Entretanto, Freitas (2016), em suas análises sobre os impactos desse referencial, discute que o controle do currículo não promove o desenvolvimento dos sujeitos por meio da educação, mas os reduz ao ato modulador, pois, ao treiná-los para responder a testes, direcionam o ato educativo ao "bancarismo" que, segundo a educação bancária mencionada por Freire (1987), conserva a padronização do ensino; define os conteúdos que devem ser ensinados, os modos como devem ser abordados; e, em consequência, gera a reprodução de um modelo educativo que, de modo acrítico, é interiorizado pela cultura escolar como componente "natural" da relação ensino-aprendizagem.

Freitas (2016) discute ainda que esse modelo educacional prioriza práticas e condutas que incorporam os modos avaliativos ao trabalho pedagógico a partir de diferentes nomenclaturas que sugerem "certa mediação" da relação ensino-aprendizagem e revelam muito mais das características excludentes e classificatórias, intrínsecas à operacionalização pontual dos instrumentos avaliativos, do que a análise e a reflexão sobre os intrincados 
movimentos que, segundo a teoria que fundamenta este trabalho, compõem o processo de aprendizagem com vistas ao efetivo desenvolvimento, ao "salto qualitativo" que possibilita ao sujeito a passagem do pensamento empírico ao pensamento teórico.

Nesse movimento, o processo que leva à aprendizagem, uma vez compreendido como apropriação do conhecimento com vistas à humanização, não se situa apenas no movimento individual que relaciona a aplicação de instrumentos avaliativos à pseudointencionalidade pedagógica ou aos resultados que apontam para conquista da autonomia intelectual, mas tem sua gênese na relação e na inter-relação que promove uma mudança na sociedade, pela transformação que, de antemão, ocorre continuamente nos sujeitos.

Sobre essa transformação, Moretti (2007) explica que o professor se constitui professor, ao passo que, entre momentos de reflexão e ação, organiza seu trabalho; ou seja, organiza o ensino de modo que este favoreça a aprendizagem, a fim de prover ao estudante a concretização de sua principal atividade: a atividade de estudo. "Ela deve criar nele um motivo especial para sua atividade: estudar e aprender teoricamente sobre a realidade" (MOURA et al., 2016, p. 103).

Assim, tanto o professor em atividade de ensino como o estudante em atividade de estudo se constituem como sujeitos em transformação, à medida que ambos se apropriam dos conhecimentos construídos socialmente.

A avaliação, nessa relação, como premissa e produto que se configura entre o ensino e a aprendizagem, revela-se sob a ótica da avaliação dialética que, para além da operacionalização de um instrumento verificador de aprendizagens, supera e avança para a concepção que a configura como ação inerente ao sujeito e, com isso, inerente à relação ensino-aprendizagem, a qual na atividade pedagógica apresenta-se intencionalmente como ação-instrumento que visa desencadear as possibilidades de desenvolvimento humano.

Todavia, entendemos que avaliar implica mais do que a operacionalização pontual de diferentes instrumentos medidores de aprendizagem, pois é uma ação que se concretiza na relação em que o professor, ao organizar situações de ensino, objetiva, de fato, promover a aprendizagem dos estudantes. Desse modo, como ação-instrumento, a avaliação não virá a coincidir direta e exatamente com o fim da atividade de ensino, mas se constituirá como elemento 
independente, que, por sua vez, não pode existir fora do processo de planejamento, realização e desfecho, do qual o professor lança mão como fator decisivo para que a avaliação "seja mediadora entre as atividades de ensino e as de aprendizagem" (MORAES, 2008, p.14).

De acordo com Moura et al. (2016, p. 115), "não existe atividade de aprendizagem intencional se ela não se dá de forma consciente e organizada por meio da atividade de ensino". Desse modo, a qualidade da mediação possibilitada pela avaliação como um processo que se constitui dialeticamente surge como ato intencional, que permite que a atividade de ensino se concretize na atividade de aprendizagem, com vistas ao desenvolvimento da máxima potencialidade humana.

Nessa direção, em nossa próxima discussão, apresentaremos a análise de alguns dos materiais utilizados pela Secretaria Municipal de Educação (SME) do município campo, em que observamos a transformação nos modos de avaliação da aprendizagem dos estudantes. Essa análise é marcada cronologicamente por três diferentes períodos: ano de 2016; anos entre 2017 e 2019; e, por último, ano de 2020. Cabe ressaltar que o primeiro período será tratado a seguir, enquanto que os dois últimos serão discutidos mais à frente.

\subsection{Análise de instrumentos comumente operacionalizados para verificação da aprendizagem}

Nosso intuito, ao destacar as práticas avaliativas da Secretaria Municipal de Educação, compreende a possibilidade de analisar, ao longo do processo de transformação dos instrumentos de verificação, modos de avaliação que, para além da medição, possam ser compreendidos como unidade mediadora dessa relação.

Tal discussão dá-se no âmbito do desenvolvimento do Programa Melhoria do Ensino Público, da Fapesp, pelo projeto ao qual essa pesquisa se vincula "A gênese e o desenvolvimento da organização curricular em matemática em um munícipio paulista" (2016-2020) -, cuja parceria entre município e universidade tinha como objetivo central a organização do currículo de Matemática para os anos iniciais. Portanto, dentro do projeto Fapesp, colocamo-nos a discutir e analisar a avaliação como unidade ação-instrumento que, apesar de intrínseca 
à atividade humana e à relação ensino-aprendizagem, não se constitui como elemento "naturalizado", ou seja, não ocorre espontaneamente em toda e qualquer situação, mas, pelo contrário, requer que a organização intencional da atividade de ensino, como via principal, crie a "possibilidade de participar enquanto criador de todas as manifestações da vida humana" (LEONTIEV, 2004, p. 302).

Em nosso movimento, inicialmente, trataremos de uma amostra dos instrumentos que, em 2016, eram utilizados em ocasiões pontuais por professores desta rede e, denominados "avaliações somativas", configuravamse como subsídio para verificação da aprendizagem consolidada pelos estudantes nas diferentes áreas e disciplinas ao longo de um período de trabalho desenvolvido pelos professores.

O estudo desse material, que, embora não corresponda à atual prática da Secretaria Municipal de Educação, revela os limites impostos por normativas advindas de políticas públicas que buscamos constantemente colocar no campo da análise, não perde sua relevância. E, apesar de particular, possibilita-nos generalizar os modos avaliativos que se exteriorizam para além dos limites desta secretaria, uma vez que ilustra o que comumente ocorre em muitas escolas brasileiras.

Exemplos dessa ilustração podem ser constatados com a aplicação periódica em toda rede estadual paulista das Avaliações da Aprendizagem em Processo (AAP), e também, em escala nacional, com a aplicação da Avaliação Nacional da Alfabetização (ANA) (BRASIL, 2013b) e da Prova Brasil (BRASIL, 2013a), que, em suma, representam instrumentos externos às escolas, cujo objetivo é aferir e monitorar a proficiência dos estudantes nos componentes curriculares correspondentes às áreas de Língua Portuguesa e Matemática e estabelecer parâmetros de comparação em relação às metas do Índice de Desenvolvimento da Educação Básica (IDEB).

Além disso, há de se considerar que, muitas vezes, os instrumentos construídos pelos próprios professores, de acordo com Freitas (2014), comumente sofrem com a influência das avaliações externas, primeiro por serem produzidos a partir dos mesmos modelos e, segundo, por exercerem funções que se assemelham a simuladores preparatórios, que, no lugar de conceitos, ensinam a responder a testes. 
É nesse ponto que a avaliação externa de larga escala se conecta com a avaliação interna à escola e modula, em especial, os processos de avaliação informal atingindo os professores e as crianças.

As relações entre as avaliações externas de larga escala e as avaliações formais internas à escola ocorrem em vários momentos, mas, especialmente, no que conhecemos como "simuladores" destinados a preparar para os testes e também na organização das provas internas regulares da escola que acabam voltando-se para o mesmo objetivo. (FREITAS, 2014, p. 1096)

A análise do material utilizado em 2016, do qual nos concentramos apenas nos instrumentos para verificação da aprendizagem dos estudantes em Matemática, levou-nos à construção de um quadro ${ }^{8}$ em que, além do conceito avaliado, indicamos os objetivos centrais de cada um dos exercícios utilizados. Para nosso estudo, no Quadro 5, destacamos o conceito e os objetivos avaliados que remetem às habilidades ${ }^{9}$ analisadas no capítulo anterior:

\begin{tabular}{|c|c|c|c|c|c|}
\hline \multicolumn{6}{|c|}{ Comparativo entre as Avaliações Somativas do $1 . .^{\circ}$ ao $5 .^{\circ}$ ano do EF } \\
\hline \multirow{2}{*}{$\begin{array}{l}\text { Conceito } \\
\text { avaliado }\end{array}$} & \multicolumn{5}{|c|}{ Objetivos centrais dos exercícios utilizados para avaliar } \\
\hline & $1 . \circ$ ano & 2.. ano & 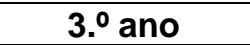 & $4 .-$ ano & $5 .$. ano \\
\hline $\begin{array}{c}\text { Compreensão } \\
\text { do sistema } \\
\text { indo-arábico } \\
\text { de numeração } \\
\text { decimal }\end{array}$ & $\begin{array}{l}\text { Escrita numérica } \\
\text { a partir do } \\
\text { ditado feito pelo } \\
\text { professor. } \\
\text { Identificação } \\
\text { dos números } \\
\text { que faltam em } \\
\text { uma sequência } \\
\text { (1 ao 10) e sua } \\
\text { escrita. } \\
\text { Identificação } \\
\text { das formas de } \\
\text { uso dos } \\
\text { números } \\
\text { (contagem, } \\
\text { medida, ordem } \\
\text { e código). }\end{array}$ & $\begin{array}{l}\text { Escrita numérica } \\
\text { a partir do } \\
\text { ditado feito pelo } \\
\text { professor. } \\
\text { Identificação } \\
\text { dos números } \\
\text { que faltam em } \\
\text { uma sequência } \\
\text { (1 ao 40) e sua } \\
\text { escrita. } \\
\text { Localização de } \\
\text { lugares em } \\
\text { mapas e } \\
\text { lateralidade } \\
\text { (direita e } \\
\text { esquerda). }\end{array}$ & $\begin{array}{l}\text { Escrita numérica } \\
\text { a partir do } \\
\text { ditado feito pelo } \\
\text { professor e } \\
\text { identificação de } \\
\text { valor posicional } \\
\text { de numeral com } \\
\text { três ordens. } \\
\text { Identificação } \\
\text { dos números } \\
\text { que faltam em } \\
\text { uma sequência } \\
\text { (de } 10 \text { em 10). }\end{array}$ & $\begin{array}{l}\text { Escrita numérica } \\
\text { a partir da } \\
\text { representação } \\
\text { feita com } \\
\text { Material } \\
\text { Dourado. } \\
\text { Identificação do } \\
\text { valor posicional } \\
\text { e escrita por } \\
\text { extenso. }\end{array}$ & 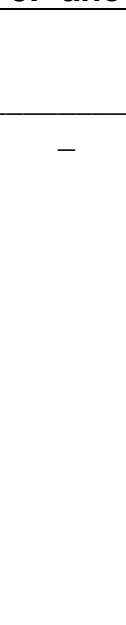 \\
\hline
\end{tabular}

\footnotetext{
${ }^{8}$ Exemplo dos materiais analisados que originaram o quadro foram compilados no Anexo 1 desta pesquisa.

${ }_{9}$ EF03MA23 - Ler horas em relógios digitais e em relógios analógicos e reconhecer a relação entre hora e minutos e entre minuto e segundos.

EF04MA22 - Ler e registrar medidas e intervalos de tempo em horas, minutos e segundos em situações relacionadas ao seu cotidiano, como informar os horários de início e término de realização de uma tarefa e sua duração.
} 


\begin{tabular}{|c|c|c|c|c|c|}
\hline & $\begin{array}{l}\text { Comparação } \\
\text { entre coleções } \\
\text { de objetos e } \\
\text { registro do signo } \\
\text { correspondente. }\end{array}$ & & & & \\
\hline \multirow{2}{*}{$\begin{array}{l}\text { Compreensão } \\
\text { do sistema de } \\
\text { numeração } \\
\text { maia }\end{array}$} & & & & \multirow{2}{*}{$\begin{array}{l}\text { Compreender a } \\
\text { lógica do } \\
\text { sistema de } \\
\text { numeração } \\
\text { decimal maia e } \\
\text { identificar os } \\
\text { números } \\
\text { apresentados. }\end{array}$} & \\
\hline & & - & - & & - \\
\hline \multirow{2}{*}{$\begin{array}{l}\text { Relação entre } \\
\text { signo, número } \\
\text { e numeral }\end{array}$} & $\begin{array}{l}\text { Contar duas } \\
\text { coleções de }\end{array}$ & \multirow{2}{*}{$\begin{array}{l}\text { Identificar o } \\
\text { numeral } \\
\text { referente ao } \\
\text { signo. }\end{array}$} & & & \\
\hline & $\begin{array}{l}\text { objetos e } \\
\text { registrar o signo } \\
\text { correspondente } \\
\text { a cada uma. } \\
\text { Comparação de } \\
\text { quantidades. }\end{array}$ & & - & - & - \\
\hline \multirow[t]{2}{*}{$\begin{array}{c}\text { Leitura e } \\
\text { interpretação } \\
\text { de gráfico e } \\
\text { tabela }\end{array}$} & & \multirow{2}{*}{$\begin{array}{l}\text { Localização de } \\
\text { informações } \\
\text { presentes em } \\
\text { tabela simples. } \\
\text { Montagem de } \\
\text { gráfico de } \\
\text { barras (verticais) } \\
\text { a partir de } \\
\text { informações } \\
\text { previamente } \\
\text { determinadas. }\end{array}$} & \multirow{2}{*}{$\begin{array}{l}\text { Montagem de } \\
\text { gráfico de } \\
\text { barras (verticais) } \\
\text { a partir de } \\
\text { informações } \\
\text { previamente } \\
\text { determinadas e } \\
\text { interpretação } \\
\text { dos dados } \\
\text { apresentados. }\end{array}$} & \multirow{2}{*}{$\begin{array}{l}\text { Localização de } \\
\text { informações } \\
\text { explícitas } \\
\text { presentes em } \\
\text { gráfico de } \\
\text { barras } \\
\text { (horizontal) e } \\
\text { em tabela de } \\
\text { dupla entrada. }\end{array}$} & \\
\hline & & & & & - \\
\hline \multirow{2}{*}{$\begin{array}{l}\text { Resolução de } \\
\text { situação- } \\
\text { problema }\end{array}$} & & \multirow{2}{*}{$\begin{array}{l}\text { Identificação } \\
\text { das ideias do } \\
\text { campo } \\
\text { multiplicativo } \\
\text { (multiplicação). } \\
\text { Resolução de } \\
\text { problemas. }\end{array}$} & & & \multirow{2}{*}{$\begin{array}{l}\text { Resolução de } \\
\text { situação- } \\
\text { problema que } \\
\text { envolve ideia de } \\
\text { fração. }\end{array}$} \\
\hline & & & - & - & \\
\hline $\begin{array}{l}\text { Identificação } \\
\text { de formas } \\
\text { geométricas }\end{array}$ & & $\begin{array}{l}\text { Relação entre } \\
\text { objetos do } \\
\text { cotidiano e } \\
\text { formas } \\
\text { geométricas } \\
\text { sólidas. }\end{array}$ & $\begin{array}{l}\text { Relação entre } \\
\text { objetos do } \\
\text { cotidiano e } \\
\text { formas } \\
\text { geométricas } \\
\text { sólidas. } \\
\text { Identificação de } \\
\text { planificação } \\
\text { referente a uma } \\
\text { forma } \\
\text { geométrica } \\
\text { sólida. }\end{array}$ & $\begin{array}{l}\text { Identificação de } \\
\text { características } \\
\text { das formas } \\
\text { geométricas } \\
\text { sólidas. }\end{array}$ & $\begin{array}{l}\text { Relação entre } \\
\text { objetos do } \\
\text { cotidiano e } \\
\text { formas } \\
\text { geométricas } \\
\text { sólidas. } \\
\text { Identificação de } \\
\text { características } \\
\text { das formas } \\
\text { geométricas } \\
\text { sólidas. }\end{array}$ \\
\hline $\begin{array}{l}\text { Compreensão } \\
\text { sobre unidade } \\
\text { de medida de } \\
\text { tempo }\end{array}$ & & - & $\begin{array}{c}\text { Identificação de } \\
\text { horas e a } \\
\text { passagem do } \\
\text { tempo. }\end{array}$ & & $\begin{array}{l}\text { Representação } \\
\text { de hora em } \\
\text { relógio de } \\
\text { ponteiros. }\end{array}$ \\
\hline \multirow{2}{*}{$\begin{array}{l}\text { Cálculo por } \\
\text { meio do } \\
\text { algoritmo } \\
\text { convencional }\end{array}$} & & & & & \multirow{2}{*}{$\begin{array}{l}\text { Calcular os } \\
\text { resultados das } \\
\text { multiplicações, } \\
\text { adições e } \\
\text { subtrações. }\end{array}$} \\
\hline & & - & - & - & \\
\hline $\begin{array}{c}\text { Compreensão } \\
\text { da } \\
\text { representação } \\
\text { e aplicação de } \\
\text { fraçőes } \\
\end{array}$ & & & & & $\begin{array}{l}\text { Identificação de } \\
\text { frações } \\
\text { representadas } \\
\text { em desenhos. }\end{array}$ \\
\hline
\end{tabular}


QUADRO 5 - Comparativo entre Avaliações Somativas do 1.ำ ao 5.ำ ano do EF (2016). Fonte: Material concedido pela SME. Organizado pela autora.

Ao analisarmos esses instrumentos de avaliação, identificamos três aspectos relevantes a serem destacados para nossa discussão. O primeiro traz à luz a questão da organização do ensino em ambiente escolar, apontando para a conservação daqueles conhecimentos próprios do meio circundante.

Este aspecto nos dirige ao nosso segundo ponto de análise: coloca-se em evidência como a necessidade humana que deu origem ao desenvolvimento do conceito, neste caso, tem sido associada à necessidade utilitária, afastando do estudante o processo lógico-histórico que considera o movimento de elaboração do conceito, uma vez que ele é apresentado em sua forma final, cuja aplicação imediatista não possui força suficiente para clarificar a distinção entre os conceitos científicos e os de cunho cotidiano. A sequência didática sobre 0 ensino das horas, discutida anteriormente, constitui-se como um exemplo, cujo ensino do conceito volta-se aos elementos externos e aparentes dos fenômenos.

O terceiro aspecto faz referência à característica estática do instrumento avaliativo que, mesmo operacionalizado em diferentes momentos, pouco contribui para que o professor identifique a potencialidade de seus estudantes e possa, de fato, organizar o ensino para que sejam desenvolvidas as mudanças qualitativas que marcam a passagem do pensamento empírico ao teórico.

Sobre os primeiros apontamentos, discutimos no capítulo anterior as características do ensino que remete ao desenvolvimento de habilidades como as explicitadas pela Base, que optam por priorizar a simplificação do conceito em lugar de seu aprofundamento, uma vez que relacionam a "identificação e leitura de horas em relógios de ponteiros" ao conhecimento necessário para 0 desenvolvimento do cidadão.

Para Davidov (2017), este modelo, em que os princípios do ensino se alinham à conservação de conhecimentos cotidianos, volta-se ao desenvolvimento de habilidades que colocam o pensamento empírico em lugar de destaque, revelando-se um processo educativo pouco potencializador para o desenvolvimento do novo, da mudança qualitativa.

Desse modo, compreendemos que esta prática não necessariamente precisa ser excluída da atividade de ensino; entretanto, no modo como se 
apresenta, acaba por obstaculizar o desenvolvimento das particularidades do pensamento teórico do estudante (e do professor), pois,

com o ingresso na escola, a criança deve sentir claramente o caráter novo e a peculiaridade daqueles conceitos que agora recebe, isto é, a diferença da experiência pré-escolar. Trata-se de conceitos científicos que precisam ser abordados com procedimento distinto e inesperado, em comparação a como os pequenos tratavam os significados da palavra "casa", "rua" etc. (DAVIDOV, 2017, p. 218)

Rosa (2012), ao discutir as proposições de Davidov para o ensino de Matemática no primeiro ano escolar, aponta como característica da conservação do conhecimento empírico o ensino centrado na observação das propriedades externas dos objetos, apoiando-se, principalmente, em representações visuais, associadas a abstrações verbais que abordam o conceito de modo genérico, para que, em sua forma minimizada, torne-se mais acessível aos estudantes desde os primeiros anos.

Para nós, estas características apontadas por Davidov e discutidas por Rosa (2012) se assemelham àquelas explicitadas pelos instrumentos analisados, em que, em relação ao ensino do conceito desta unidade de medida, limitou-se ao reconhecimento e à leitura das horas, a partir da observação dos ponteiros. Além disso, estes instrumentos explicitam a desconexão entre 0 desenvolvimento lógico e histórico, considerando-o apenas em seu estado final, como se o fruto da necessidade humana se revelasse de modo instantâneo na criação do instrumento de medida do tempo.

Nessa relação, a necessidade criadora do homem, firmando-se no desenvolvimento de habilidades que priorizam a necessidade utilitária como fonte para a formação do cidadão e qualificação para o trabalho, abre mão de sua essência, afigurando-se em uma relação em que os sujeitos e os nexos que deveriam trazer vida aos conceitos se revelam vazios.

Nas palavras de Freire (2005), esse modelo educacional diz respeito a uma educação que se configura "verbosa e palavresca", pois "é 'sonora', é 'assistencializadora'. Não comunica. Faz comunicados, coisas diferentes" (FREIRE, 2005, p. 101, grifos do autor).

Para Davidov (2017), os princípios da escola tradicional se revelam, sobretudo, no desenvolvimento de conhecimentos e habilidades pertencentes ao 
campo utilitário-empírico, ao passo que reduzem o conceito de unidade de medida de tempo à necessidade que se impõe de manuseio e utilização do relógio na prática cotidiana, sem considerar as múltiplas determinações que envolvem desde os movimentos de rotação e translação da Terra, a divisão do globo pelas linhas imaginárias que marcam os fusos e a separação entre os hemisférios, além de todo o percurso do homem por esse caminho.

Destacamos também que esse modelo, assim como descreve Freitas (2014), revela menor criticidade tanto em relação ao processo de apropriação por parte dos escolares, como no que diz respeito aos processos que envolvem a atividade docente, pois levam o professor a discussões superficiais que tratam ingenuamente dos modos de organização do ensino (FREIRE, 2005) e se objetivam na incorporação de práticas avaliativas que, em sua dimensão operacional e instrumental, configuram-se como única fonte de análise e planejamento (FREITAS, 2014), colocando à margem as reais possibilidades de apropriação da cultura.

A avaliação, nesta configuração, desvela-se como elemento estático que possibilita somente a constatação daquilo que o estudante registrou no papel, o que, neste exemplo, restringe-se ao reconhecimento das horas, limitando o professor àquilo que pode ser "observável" para servir como requisito capaz de validar (ou não) a conquista da autonomia intelectual pelo estudante, lugar este em que o desenvolvimento humano se subordina à medição de inteligência e da capacidade, em detrimento das significações que mobilizam os sujeitos e os colocam em atividade.

Vigotski (2001) explica ainda que o ensino que se orienta por aquilo que o estudante revela como conhecimento amadurecido, firmado em seu nível de desenvolvimento real, ao ser aferido por avaliações que cumprem função verificadora da aprendizagem, pouco pode contribuir para apropriação dos nexos próprios do pensamento teórico, pois o ensino que direciona seus esforços àquilo que já não pode revelar nenhuma mudança substancial sobre o desenvolvimento torna-se desnecessário à relação ensino-aprendizagem:

O ensino seria totalmente desnecessário se pudesse utilizar apenas o que já está maduro no desenvolvimento, se ele mesmo não fosse fonte de desenvolvimento e surgimento do novo. Por isso a aprendizagem só é mais frutífera quando se realiza nos limites de um período determinado pela zona de desenvolvimento proximal. [...] É aí que 
certas influências exercem efeito sensível sobre todo curso do desenvolvimento, provocando nele mudanças de variedades profundas. (VIGOTSKI, 2001, p. 334-335)

Desse modo, defendemos que a educação escolar deve organizar-se em oposição à avaliação para o ontem, que se orienta pela "pseudointencionalidade pedagógica", uma vez que não leva em consideração a unidade entre ensino e aprendizagem, ao correlacionar sua aplicação às possibilidades de verificação da aprendizagem do estudante. Defendemos também que, tanto em sua dimensão instrumental como operacional, as práticas avaliativas revelam apenas fragmentos daquilo que outrora foi apropriado pelos sujeitos, e não aqueles traços que destacam a potencialidade humana do vir a ser.

Isto não quer dizer que a prática educativa deva colocar à margem o uso de um instrumento de avaliação, mas precisa compreendê-lo e qualificá-lo como parte do todo, e não como o todo, ou seja, não como fim da educação.

Nesse sentido, compreender o uso de um instrumento recai sobre o que Vigotski (2001, p. 342, destaque nosso) explica em relação à imitação:

Quando afirmamos que a criança age por imitação, isso não quer dizer que ela olhe outra pessoa nos olhos e imite. Se eu vi alguma coisa hoje e faço a mesma coisa amanhã, eu o faço por imitação. Quando em casa uma criança resolve problemas depois de ter visto a amostra em sala de aula, ela continua a agir em colaboração, embora nesse momento o professor não esteja ao seu lado. [...] Essa ajuda, esse momento de colaboração, está presente, está contido de forma aparentemente autônoma na resolução da criança.

Assim como tarefas realizadas em casa, os testes escolares, assumidos equivocadamente como avaliações da aprendizagem, em lugar de explicitadores de saberes, devem indicar ao professor que aquilo que o estudante faz, ao solucionar individualmente um problema, representa uma possibilidade de passar do que ele sabe para aquilo que não sabe, mas que está próximo ao seu nível de desenvolvimento, "coincidindo perfeitamente com a sua zona de desenvolvimento imediato" (VIGOTSKI, 2001, p. 329).

A avaliação, nessa perspectiva, configura-se como elemento intrínseco ao ensino e à aprendizagem, possibilitando ao professor a ascensão do papel de mediador entre o conhecimento e o estudante, para ocupar o espaço de organizador do ensino, em acordo com o que afirma Piotto (2020, p. 351) sobre 
o papel do professor, ao tratar da Atividade Orientadora de Ensino, cuja discussão faremos mais à frente:

\begin{abstract}
Em plena consonância com a Teoria Histórico-cultural, o professor é figura central e absolutamente imprescindível para a AOE. É ele quem, tendo se apropriado do conceito e modifica-se, pode, em coletividade, organizar sua atividade de ensino de modo a mobilizar os estudantes para a apropriação do conceito por meio da recriação de uma necessidade que também moveu o ser humano em seu processo histórico de desenvolvimento. E assim fazendo permitir com que outros também se apropriem do conceito e modifiquem-se a si próprios.
\end{abstract}

Entretanto, para que os sujeitos possam ocupar este espaço, é necessária nova significação da relação ensino-aprendizagem, bem como das práticas e condutas "naturalizadas" pela cultura escolar.

Isto significa compreender que o desenvolvimento, na perspectiva que temos afirmado, dá-se na relação e na inter-relação entre os sujeitos, surgindo pela primeira vez na atividade coletiva como função interpsíquica e, após, como atividade individual, singular ao próprio pensamento, como função intrapsíquica (VIGOSTKI, 2010).

Esta tese torna a participação coletiva pedra angular na construção de um currículo que tem como gênese a formação humana e, sobretudo em atividade de ensino e atividade de estudo, enseja um currículo vivaz, que, ao longo do processo ensino-aprendizagem, possibilita que os sujeitos tenham condições de assumir-se como "parte fundamental do todo" (MAKARENKO, 2012, p. 650), ao passo que o constroem e o vivenciam, partilhando dos mesmos objetivos e ações que os levem a alcançá-los.

Sentindo-se "corresponsáveis pelo coletivo" (MAKARENKO, 2012, p. 650), pela partilha e apropriação dos conhecimentos construídos pelas gerações precedentes e, sobretudo, pela possibilidade de humanização, a avaliação para os sujeitos envolvidos na relação ensino-aprendizagem adquire nova qualidade e nova significação, que, para além da operacionalização instrumental, pode mediar as relações humanas e os modos que compõem a organização do ensino para o ensino.

Na seção a seguir, abordaremos a concepção que temos defendido sobre avaliação dialética, discutindo em que medida, para o professor e para 0 estudante, ela possibilita a apropriação das conquistas do desenvolvimento 
histórico do homem, que se objetiva "por meio da internalização das conquistas do desenvolvimento da espécie, que é, em seu ato maior, o desenvolvimento das funções psicológicas superiores" (RIGON; ASBAR; MORETTI, 2016, p. 75), por meio de um ato educativo intencionalmente planejado para este fim.

\subsection{A dimensão dialética da avaliação}

Ao tratarmos da avaliação em sua dimensão instrumental e operacional, com o objetivo de discutir as implicações e os limites que se referem à organização do ensino, sobretudo em relação ao currículo e às práticas docentes, uma vez que estas respondem às normativas advindas dos referenciais e ao abordarmos os materiais utilizados pela Secretaria Municipal de Educação em 2016, buscamos destacar a relevância atribuída aos instrumentos que, como principais sinalizadores do desempenho das escolas e do trabalho desenvolvido pelos professores, comumente se naturalizam como fonte de análise e planejamento da relação ensino-aprendizagem (FREITAS, 2014) e integram-se à cultura escolar com diferentes nomenclaturas que colaboram para melhor aceitação pelos sujeitos.

De modo geral, fundamentando-nos nas proposições de Davidov (1988, 2017) e Davydov (1999), as quais também foram discutidas por Rosa (2012), observamos os modos como essas avaliações revelam práticas escolares que conservam conceitos relacionados ao meio circundante e a sua aplicação imediatista. Isso implica na obstaculização da formação dos fundamentos do pensamento teórico, considerados pelo autor como principais processos da formação da personalidade criativa e multilateralmente desenvolvida, ao passo que as avaliações são organizadas a partir de exercícios cujos objetivos centrais, de acordo com nosso estudo, desconsideram o processo lógico-histórico de desenvolvimento dos conceitos.

Outro ponto desta análise trata dos limites de sua aplicação, no que diz respeito à característica estática da ferramenta que, mesmo operacionalizada para verificação das aprendizagens em diferentes situações e com diferentes objetivos, pouco revela as possibilidades de desenvolvimento, pois, embora partamos da premissa de que a aprendizagem pode levar ao desenvolvimento, 
defendemos a tese vigotskiana de que aprendizagem e desenvolvimento nunca estão em igualdade ou ocorrem concomitantemente.

Nesse sentido, tal princípio, compreendido em sua essência, indica a impossibilidade de ambos os processos serem medidos por testes, em que o foco, semelhante àquele que é atribuído às principais ferramentas avaliativas, encontra-se na necessidade de verificar conquistas escolares, relacionando-as à conquista da autonomia intelectual, uma vez que, de acordo com Vigotski (2010, p. 487, grifo do autor),

\begin{abstract}
o desenvolvimento da criança nunca segue a aprendizagem escolar como uma sombra atrás do objeto que a projeta. Por isso os testes de conquistas escolares nunca refletem a marcha real do desenvolvimento da criança. Em realidade, entre os processos de desenvolvimento e aprendizagem se estabelecem dependências dinâmicas as mais complexas, que não podem ser abrangidas por uma fórmula especulativa única e a priori.
\end{abstract}

Desse modo, para além de sua dimensão instrumental e operacional, a avaliação centralizada na explicitude de "saberes" como meio para constatação da conquista da autonomia intelectual necessita ser qualificada a partir da perspectiva que traz em sua gênese a compreensão das implicações do ato educativo como premissa propulsora das possibilidades de desenvolvimento que levam o homem a humanizar-se.

Se, na concepção de avaliação mediadora, o conteúdo prende-se à relação retrospectiva, ao medir conquistas escolares e, com isto, fundamentar o planejamento de ações docentes ao considerar os erros dos estudantes como caminho para construção de novos saberes (HOFFMANN, 1992), na avaliação dialética, compreendida como ação inerente à atividade humana, torna-se inerente à atividade educativa e configura-se como unidade mediadora que suprime o hiato presente na relação ensino-aprendizagem, ao passo que possibilita as condições de desenvolvimento dos nexos próprios do pensamento teórico, pois indicam ao professor "a possibilidade maior ou menor de que a criança passe do que sabe fazer sozinha para o que sabe fazer em colaboração" (VIGOTSKI, 2001, p. 329). E apenas isto, de acordo com Vigotski (2001), pode caracterizar a dinâmica do desenvolvimento e do êxito da criança.

Esta passagem, oportunizada pelo ensino devidamente organizado com esta finalidade e para ela, pode permitir "aos sujeitos a apropriação dos 
conhecimentos, de habilidades e de formas de comportamentos produzidos pela humanidade" (RIGON; ASBAR; MORETTI, 2016, p. 33), de tal modo que não fariam sozinhos.

Diante desta perspectiva, qualificar a avaliação como ação intrínseca significa compreendê-la no movimento dialético que impulsiona e permite não apenas uma análise individual retrospectiva e explicitadora dos nexos de antemão apropriados pelo sujeito, mas também, essencialmente, uma análise prospectiva no que se refere à organização intencional e planejada do ensino que tem como cerne o desenvolvimento coletivo. Isso porque, assim como temos afirmado com base nas pesquisas de Araujo (2003), Moraes (2008), Moura et al. (2010), Brito (2017) e outros autores, o ensino que promove aprendizagem que possibilita a humanização dos envolvidos se constitui entre o ensinar e o aprender, que se relaciona tanto à pessoa do educando, como à pessoa do educador.

A avaliação, defendida como avaliação dialética, apresenta-se no processo de constituição do ensino e da aprendizagem, lugar em que novas relações, assim como metamorfoses, ocorrem diante de nossos olhos e adquirem nova dimensão, conduzindo os sujeitos a um circuito de transformações e mudanças qualitativas que fazem surgir "uma nova forma que, no degrau precedente, não existia, apesar de seu surgimento ter sido preparado pelo desenvolvimento anterior" (VIGOSTKI, 2018, p. 29).

Este movimento, assim como aquele que permite a metamorfose que leva a lagarta a tornar-se borboleta, não pode ser reduzido aos limites dos resultados evidenciados pelos instrumentos que apontam para o acúmulo ou incremento de informações organizadas didaticamente, em detrimento de todo o processo lógico-histórico, limiar a cada um dos conceitos. Isto envolve uma série de mudanças, em que o real desenvolvimento é construído pelo e no movimento em que se estabelecem "novas metas, para satisfazer novas necessidades, que exigirão novas ações" (MOURA, 2000, p. 28). E essas podem levar a novos usos desses e de outros instrumentos, possibilitando ao fazer docente uma mudança metodológica que se situa para além das usuais nomenclaturas atribuídas às velhas práticas avaliativas.

Há de se ressaltar que a concepção de avaliação pela ótica que a compreende em sua dimensão dialética vincula-se à teoria vigotskiana, no que 
se refere à tese acerca do desenvolvimento das relações internas a partir das relações externas (VIGOTSKI, 2001), ao passo que se organizam situações educativas em que as condições objetivas possibilitam práticas conscientes, pois, assim como o professor que, para não incorrer em modos de ensino que se baseiam unicamente em livros didáticos, necessita ter-se apropriado da relação essencial da construção dos conceitos (MORAES, 2008), compreendemos que "a criança que entende o que está acontecendo, que entende o significado do que se passa, reagirá de forma diferente daquela que não o faz" (VIGOSTSKI, 2018).

Nessa direção, destacamos que as práticas propulsoras das relações humanas ocorrem ao longo do trabalho em que a coletividade se faz presente, sobretudo como produto da vivência, em que os sujeitos envolvidos partilham de objetivos em comum e buscam desenvolver e realizar ações e operações que os levem a alcançá-los (MAKARENKO, 2012).

Tal dinâmica, em seu cerne, compreende a participação coletiva como produto das relações entre os sujeitos e, apesar de, nesta pesquisa, tratar principalmente das práticas e das condutas que abarcam as relações presentes na avaliação, defendemos que devam ser consideradas em todas as esferas implicadas pela relação ensino-aprendizagem, assim como apontamos no relato de Serra (2019) em relação à importância da participação dos professores ao longo do processo de regulação, implantação e implementação de uma proposta curricular, com ênfase na área da Matemática para as escolas do município campo de nossa pesquisa:

Não há mudança sem que os sujeitos participem de sua concepção. Portanto, não haverá "mudança" de postura metodológica dos professores, se estes não forem convidados a participar da (re)orientação curricular do município e o fizerem de fato. (SERRA, 2019, p. 71)

A compreensão apresentada por Serra (2019) acerca da construção de uma dinâmica formativa que incite mudança na postura metodológica por parte do grupo docente, de forma semelhante aos princípios discutidos anteriormente em relação à tese vigotskiana, em que o externo, como ação coletiva, ao ser internalizado pelo sujeito, torna-se motor para o desenvolvimento intrapsíquico, evidencia a relevância da coletividade como um processo que se constrói na 
relação entre os homens, na busca pela satisfação das necessidades que se impõem, motivando-os a se colocar em atividade e, com isto, possibilitando que os nexos formadores do pensamento teórico sejam apropriados.

Assim, diríamos que, mais do que um "convite a participar", os sujeitos envolvidos na relação ensino-aprendizagem precisam ser incluídos, para que compreendam como ações configuradas como de cunho individual ou autônomo, na verdade, constituem-se como parte indispensável do todo, do coletivo, do realizado em colaboração.

Moraes (2008, p. 102) defende que, para que esta apropriação também ocorra na pessoa do educador, é indispensável que este se aproprie das etapas de todo o processo de organização do ensino:

O que mobiliza os professores estarem em atividade de ensino é a
necessidade de organizar suas intervenções pedagógicas -o ensino,
o qual, se adequadamente organizado, possibilitará a aprendizagem
dos escolares e, consequentemente, proporcionará seu
desenvolvimento psicológico, isto é, uma transformação do sujeito no
movimento de apropriação dos conhecimentos teóricos. Esta
transformação não ocorre somente nos escolares, mas também no
professor, porque o docente ao apropriar-se do processo de
organização do ensino, também se desenvolve profissionalmente. Em
síntese, as ações são direcionadas pelo objetivo principal do professor
que é ensinar, para isso, suas ações consistirão no estudo, elaboração,
implementação, controle e avaliação de situações desencadeadoras
de aprendizagem.

Diante disto, destacamos que a tomada de consciência sobre essas ações possibilita ao professor condições para efetivação do objetivo da atividade de ensino, pois, ao apropriar-se de todas as etapas inerentes à sua organização, incluindo a avaliação como parte integral desse processo, apropria-se também das ferramentas psicológicas que lhe permitem analisar e compreender os nexos que se constroem entre os fios que constituem as tramas dessa relação, ou seja, os fenômenos e a essência compõem o processo educativo.

$\mathrm{Na}$ avaliação dialética isso ocorre como uma conjunção de ações, que não pode ser inserida no fazer pedagógico, mas construída por meio do contínuo caminho de formação que tem como base o desenvolvimento da atividade docente.

É importante destacarmos que nossa concepção de formação docente parte da tese apresentada por Araujo (2003), em que a autora destaca esse 
movimento como um processo de desenvolvimento profissional e pessoal, em que o professor, como sujeito que possui capacidades cognitivas de aprender, se desenvolve à medida que se constitui como sujeito não apenas ativo, mas que, sobretudo, interage com outro e com o conhecimento. Nas palavras de Araujo (2003, p. 26), "esse entendimento de formação procura contemplar a natureza contínua e ampla do processo de profissionalização ao considerar que seu desenvolvimento se encerra no plano pessoal, político e epistemológico".

Podemos afirmar que tanto a compreensão apresentada por Serra (2019), assim como a que tem constituído a formação desta pesquisadora, deram-se pela nossa participação nos estudos e projetos desenvolvidos pelo GEPEAMI, que, por mais de uma década, se debruçou sobre o estudo acerca dos princípios e das práticas da organização do ensino, com atividades de pesquisa e acompanhamento das condições que abarcam o desenvolvimento do pensamento teórico do professor e o colocam em atividade, com vistas à apropriação da cultura humana (ARAUJO, 2016).

Há de se ressaltar que, apesar dos diferentes motivos mobilizadores da inserção de cada integrante nas atividades do grupo, construímos, em parceria e com orientação da professora Elaine Sampaio Araujo, uma dinâmica de estudos significada pelo desenvolvimento do projeto "A gênese $\mathrm{e}$ desenvolvimento da organização curricular em matemática em um município paulista" que, com início em 2016, pôde ser realizado em conjunto com professores e equipe técnica do Núcleo Pedagógico (NP) da Secretaria Municipal de Educação do município campo, cuja participação nas atividades de estudo e pesquisa do GEPEAMI ocorre desde o desenvolvimento de projetos de pesquisa anteriores.

Por ser este um projeto formativo dinâmico, ao traçarmos ações de acompanhamento das relações que o compõem, desde a organização curricular para o ensino em Matemática, até os processos que envolvem 0 desenvolvimento da aprendizagem docente, nosso eixo norteador, centrou-se, principalmente, no desenvolvimento das potencialidades dos sujeitos por meio do ensino escolarizado que, como temos defendido, ao ser devidamente organizado, acreditamos que pode possibilitar aos envolvidos condições para que venham a apropriar-se da cultura humana (VIGOTSKI, 2018). 
Nesse sentido, considerar a avaliação como objeto de estudo filiado ao projeto inicialmente possibilitou-nos investigar o papel dos instrumentos utilizados para verificar a "aprendizagem", levando-nos a compreender que, mais do que um instrumento operacionalizado a favor do planejamento docente, a avaliação, compreendida em sua dimensão dialética, sob a ótica da teoria histórico-cultural, medeia todas as etapas que compõem o processo de ensino e de aprendizagem, o que implica considerá-la para além da análise da aprendizagem retrospectiva, que se volta ao que a criança realiza sozinha, como habitualmente nos mostram os resultados de testes de conhecimento, mas em direção prospectiva, ou seja, para aquilo que ela ainda não sabe, mas que, com auxílio, virá a saber.

Tomamos como exemplo a explicação apresentada por Vigotski (2001, p.238) para discutirmos este ponto de nossa análise:

\begin{abstract}
Se eu não sei jogar xadrez, isto é, se até mesmo o melhor enxadrista me mostrar como ganhar uma partida, eu não vou conseguir fazê-lo. Se eu sei aritmética, mas tenho dificuldade de resolver algum problema complexo, a mostra da resolução pode me levar imediatamente a minha própria solução, mas se eu não sei matemática superior, a mostra da solução de uma equação diferencial, não fará meu próprio pensamento dar um passo nesta direção. Para imitar é preciso ter alguma possibilidade de passar do que eu sei fazer para o que não sei.
\end{abstract}

A explicação de Vigotski (2001) mostra-nos a finalidade da avaliação dialética para a relação ensino-aprendizagem, ao passo que permite ao professor a compreensão de que, em colaboração, o estudante projeta-se ao nível superior das dificuldades intelectuais, apropriando-se daquilo que antes não estava ao seu alcance, mas que, orientando-se na direção do amanhã do desenvolvimento, poderá alcançar, ao passo que organiza situações de ensino que venham desencadear aqueles processos de desenvolvimento que o levam ao novo, ou seja, "que atualmente se encontram na zona de desenvolvimento imediato" (VIGOTSKI, 2001, p. 333).

Para continuarmos essa discussão, a seguir retomaremos nossa análise sobre alguns dos materiais utilizados pela equipe do Núcleo Pedagógico para acompanhamento das aprendizagens dos estudantes, observando dois momentos subsequentes ao ano de 2016 que, como anteriormente destacamos, correspondem aos períodos entre 2017 e 2019 e ao ano de 2020. 
Nesta análise, cujo objetivo se centra na compreensão das diferentes dimensões da avaliação, reveladas por esses materiais, para compreender nosso objeto não nos cabe examinar as práticas adotadas pela equipe do Núcleo Pedagógico, mas é preciso, sobretudo, identificar como um instrumento pode passar, de medidor da aprendizagem, para mediador da relação ensinoaprendizagem e, em sua dimensão dialética, ao configurar-se como açãoinstrumento, assumir papel de unidade mediadora que, mesmo em condições inesperadas, possibilita o surgimento de novas significações às práticas docentes, revelando-se, nas relações humanas, diante da organização e na organização do ensino.

\subsection{A avaliação dialética no ensino (remoto, o inesperado)}

Toda atividade racional do homem não é senão uma luta, a luta contra a luta pela existência. É um combate para que todas as pessoas na Terra possam satisfazer as suas necessidades, para que não tenha nem a indigência, nem a fome, nem a morte lenta. (TIMIRAREV apud LEONTIEV, 2004, p. 282)

No início desta pesquisa, acreditávamos que as implicações que poderiam ser consideradas para análise da avaliação como ação-instrumento que se configura de modo intrínseco à atividade humana e, por isso, intrínseco à atividade de ensino, estariam direcionadas, principalmente, às práticas e às condutas experienciadas em ambiente escolar, lugar em que professor e estudante vivenciam uma relação de ensino que, assim como discutimos anteriormente, comumente se orienta por resultados advindos de instrumentos avaliativos.

Entretanto, o inesperado, que, "como o próprio nome sugere, não pode ser previsto" (ARAUJO, 2003, p. 66), instalou-se diante de nós, colocando-nos, em uma nova relação com o outro, com a vida e com nossa própria existência. O inesperado trouxe consigo uma avalanche de "realidade" e "caos", instaurando uma luta desigual, em que o inimigo, mesmo invisível aos olhos, fez com que nos afastássemos fisicamente, exigindo de cada um uma força imensurável de luta por nossa existência. Uma luta inglória, em que, após um ano do primeiro caso registrado em nosso país, ainda hoje, em meados de março de 2021, sentimos na pele as marcas que ficarão gravadas na história: o triste registro de 
dezenove dias consecutivos com recordes de mortes - 0 assustador número de 2.736 óbitos, nas últimas 24 horas, decorre da pandemia causada pelo Covid19. (BRASIL TEM..., 2021).

Uma luta que evidenciou, pelos noticiários do mundo, diligências, fome, pobreza, opressão, desigualdade e, principalmente, a desumanidade do homem capitalista. Uma luta marcada pelo medo, pela incerteza e pela excepcionalidade que, assim como explica Nascimento (2020), fez com que o ensino, característico das salas de aula, excepcionalmente, chegasse à casa dos estudantes brasileiros, para que, excepcionalmente, fossem atendidos desde março até o final 2020. E, excepcionalmente, levou-nos a buscar e aplicar novas formas de ensinar (ou apenas garantir o cumprimento dos conteúdos) em meio à pandemia. "Excepcionalidade" que se estende para o ano de 2021, sem perspectivas conscientes de retorno presencial das aulas.

Diante de tantas excepcionalidades, na tentativa de garantir a vitória na luta pela vida, o ensino presencial deu lugar ao ensino remoto.

Mas será que poderíamos afirmar que o ensino remoto possibilitou a todos os estudantes condições para que se mantivessem em atividade de estudo? Ou ainda, em que medida essa modalidade escolar garantiu a todos condições para que cada estudante, dentro de seu lar, pudesse se apropriar dos bens produzidos pela humanidade?

Há de se ressaltar que tal apropriação não se refere apenas à apreensão dos conteúdos curriculares organizados didaticamente pelas áreas de Língua Portuguesa, Matemática, História e outras, mas remete à internalização dos bens culturais que, dignamente, instrumentalizam os sujeitos para que, em condições de igualdade, possam participar do coletivo social em que estão inseridos. Nas palavras de Davidov (1988, p. 11, grifos do autor, tradução nossa):

O conceito de apropriação, dentro do referencial teórico que estamos abordando, é compreendido como sendo o processo por meio do qual o sujeito "reproduz em si as formas histórico-sociais da atividade", participando de sua realização coletiva, de uma forma socialmente significativa.

Nesse sentido, colocamo-nos também a questionar: em que medida a apropriação da atividade docente, a partir das condições colocadas pelo "novo" 
modelo de trabalho, possibilitou ao professor os subsídios necessários para planejamento, organização e avaliação de sua principal atividade?

Diante destas e de outras questões, tratar da avaliação trouxe à luz a vulnerabilidade dos instrumentos utilizados para medir a aprendizagem dos estudantes, pois, se em sala de aula, em situação individual, sob o olhar atento do professor, o estudante respondia a testes que evidenciavam quais conhecimentos "haviam sido apropriados", no ensino remoto, a avaliação de caráter verificador da aprendizagem individual se tornou ineficaz, uma vez que, em casa, longe do "controle pedagógico", o estudante poderia resolver seus testes em parceria com familiares ou mesmo com o auxílio de diferentes materiais de consulta e pesquisa.

A partir do exposto, seria considerável continuarmos a análise desse objeto? Acreditamos que sim, pois, ao passo que os instrumentos avaliativos se mostraram insuficientes para verificar a aprendizagem individual e, portanto, sustentar o fornecimento de dados para planejamento e organização do ensino, significar a avaliação para além do instrumento operacional, como ação inerente aos sujeitos e, desse modo, inerente à relação ensino-aprendizagem; e compreendê-la em sua dimensão dialética, tal qual defendemos, leva-nos a analisar e refletir acerca da essência das práticas e condutas cujo núcleo compreende que o ensino da sala de aula não pode ser transferido, de modo direto, para as salas virtuais e que o conteúdo a ser apreendido não se restringe apenas a ortografia, pontuação, contagem ou operações.

Desse modo, com a intenção de apresentar uma possibilidade em que a avaliação dialética se fez presente como ação mobilizadora da relação ensinoaprendizagem, e não como instrumento medidor de conhecimentos, retomaremos, brevemente, o desenvolvimento do projeto "A gênese $\mathrm{e}$ desenvolvimento da organização curricular em matemática em um município paulista", destacando a construção e a consolidação desta ação no decorrer das situações objetivadas pelo movimento de pesquisa e estudo dos integrantes do GEPEAMI em parceria com o Núcleo Pedagógico da Secretaria Municipal de Educação do município campo.

A primeira situação a ser ressaltada corresponde à demanda posta à Secretaria Municipal de Educação em relação à publicação da última versão da $B N C C$ e, com ela, a necessidade de estruturação do currículo municipal em 
acordo com as novas orientações. Nesse sentido, o grupo que já se ocupava da elaboração do novo documento curricular para o ensino da Matemática nos anos iniciais passou a direcionar seu olhar para os princípios explicitados pela BNCC, na intenção de qualificá-los a partir dos fundamentos da teoria histórico-cultural, em que, de antemão, fundamentávamos nosso trabalho.

Diante disso, ao longo do período de vigência do projeto, foram desenvolvidos encontros formativos com professores, coordenadores pedagógicos e gestores, com o objetivo, sobretudo, de refletir acerca dos efeitos decorrentes desta publicação, discutindo sua relação normativa diante da orientação e organização do currículo e das condutas que abarcam as etapas da atividade de ensino subjacentes ao trabalho docente.

Também foram desenvolvidas práticas que contribuíram para consolidar os impactos previstos para cada uma das ações do projeto, como a organização da Oficina Pedagógica Matemática (OPM), para trabalhar com os conceitos matemáticos, atrelando-os ao objeto principal do trabalho docente: a atividade de ensino, lugar em que "tanto o conteúdo como os procedimentos metodológicos precisam estar articulados para que os alunos se apropriem teoricamente dos conhecimentos matemáticos" (MORAES, 2008, p. 74).

Outra situação que importa ser ressaltada corresponde à coincidência entre o início do projeto e a unificação das equipes do Núcleo Pedagógico da Secretaria Municipal de Educação, responsáveis pela educação infantil e pelos anos iniciais do ensino fundamental, o que as levou a alterar a prática de elaboração e envio de avaliações, que, assim como analisamos anteriormente, em síntese, correspondiam a instrumentos avaliativos operacionalizados regularmente pelos professores, configurando-se como fonte de verificação e monitoramento das aprendizagens dos estudantes nos anos iniciais.

Entretanto, essa mudança não se caracterizou como um afastamento da Secretaria Municipal de Educação em relação ao trabalho desenvolvido pelas escolas, uma vez que outros modos de diagnosticar as aprendizagens foram incorporados às práticas docentes, como uso de fichas ${ }^{10}$, que deveriam ser preenchidas no início do ano letivo e após, ao final de cada semestre e para acompanhamento das necessidades e dos avanços das crianças e das turmas.

\footnotetext{
${ }^{10}$ Exemplo do material encontra-se no Anexo 2.
} 
As informações compiladas por meio dessas fichas passaram a ser estudadas pelas próprias escolas e, com isso, em lugar do antigo instrumento avaliativo, assumiram papel orientador para os momentos de reflexões e discussões voltados ao planejamento pedagógico, bem como escopo para elaboração do Projeto Político-Pedagógico de cada uma das unidades.

Outra prática adotada correspondia ao envio de roteiros ${ }^{11}$ com sugestões de atividades para as aulas de Matemática (Guia para diagnóstico de conhecimentos matemáticos), configurando-se como subsídio para que os professores pudessem diagnosticar os conhecimentos matemáticos dos estudantes e, com isso, planejar suas ações para o ano letivo.

Antes de abordar as possibilidades de análise desses materiais, é importante enfatizar que as ações desenvolvidas pelos membros do Núcleo Pedagógico, enquanto formadoras da Secretaria Municipal de Educação, respondiam, em primeiro lugar, ao cumprimento de propostas de políticas públicas advindas da secretaria municipal e do governo estadual, e cabia aos membros do núcleo autonomia para buscar e desenvolver operações e ações que possibilitem, ao corpo docente e à equipe gestora, problematizações e reflexões acerca das condições objetivas apontadas pelos documentos reguladores.

Dito isso, retomamos o estudo desses materiais que, compreendidos como modos de diagnosticar os saberes dos educandos, permitiram-nos dois pontos de análise.

O primeiro corresponde à substituição de um material por outro, em que as fichas de acompanhamento e os roteiros de atividades passaram a ocupar o espaço que antes pertencia às avaliações somativas. Nesse movimento, ao nos atentarmos aos objetivos de cada material, foi possível observar semelhança em relação à sua essência, de modo que, ao serem operacionalizados, os objetivos de aprendizagem ou mesmo as respostas dos estudantes em cada exercício corresponderiam ainda, àqueles conhecimentos guardados no "ontem" do estudante.

Nesse sentido, por se tratar de "novos materiais", cujos objetivos permaneciam orientados pelo conhecimento já consolidado, de acordo com o

\footnotetext{
${ }^{11}$ Exemplo do material encontra-se no Anexo 3.
} 
que defende Vigotski (2010) sobre o ensino que se orienta pela zona de desenvolvimento real, compreendemos que ambos poderiam ser caracterizados como instrumentos insuficientes para refletir a marcha do real desenvolvimento do estudante.

Além disso, podemos destacar a preservação das características que os configuram como elementos externos aos sujeitos e à relação ensinoaprendizagem, uma vez que, tanto um como outro, não fizeram parte do planejamento correspondente à atividade docente. Tal externalidade evidencia para nós uma situação avaliativa que, sob a ótica que temos defendido em relação à avaliação, em sua dimensão instrumental e operacional, revela muito mais das características correspondentes a uma pseudointencionalidade pedagógica do que, de fato, das reais possibilidades de desenvolvimento humano.

Assim, ao integrarem ao espaço escolar novos modelos de acompanhamento que, em seu cerne, preservam a intenção de verificar conquistas escolares, ao mesmo tempo que se mostram insuficientes para o cumprimento da função social do ensino, recaem sobre o caráter segregacional, promovendo a responsabilização dos sujeitos pelo seu próprio sucesso ou fracasso escolar (MORAES, 2008). Isto nos mostra como a mudança conceitual em relação à avaliação é um processo mais complexo que a simples substituição do instrumento.

Nesse ponto de análise, há de se considerar que atrelar a necessidade de medir aquilo que o estudante tem consolidado ao planejamento de futuras ações pedagógicas corresponde ao que Vigotski (2001) afirma sobre um dos velhos equívocos da escola, em que a pedagogia se orienta por aquilo que a criança consegue realizar sozinha em seu pensamento, sem levar em conta a possibilidade de que o ensino, intencionalmente planejado e organizado, deve possibilitar a ela a passagem daquilo que ela sabe para aquilo que não sabe, pois "só então ela poderá desencadear no curso da aprendizagem aqueles processos de desenvolvimento que atualmente se encontram na zona de desenvolvimento imediato" (VIGOTSKI, 2001).

Para elucidarmos ainda mais nossa discussão sobre esse primeiro ponto, recorremos ao que Vigotski (2001) explica, ao tratar da questão da aprendizagem da escrita, em que a criança, ao iniciar o processo de 
alfabetização, ainda não tem apropriadas todas as funções que lhe asseguram a compreensão sobre esse sistema. Entretanto, uma vez que aquilo que ela não sabe se torna acessível em colaboração com o professor, a aprendizagem revela-se no "novo", e isso desencadeia infinitas possibilidades para desenvolver outras funções precisamente mais complexas.

\begin{abstract}
Pode-se raciocinar assim: se a escrita requer arbitrariedade, abstração e outras funções não amadurecidas no aluno, é necessário adiar a aprendizagem dessa escrita até o momento em que essas funções estejam amadurecidas. Mas a experiência mundial demonstrou que a aprendizagem da escrita é uma das matérias mais importantes da aprendizagem escolar em pleno início da escola, que ela desencadeia para a vida o desenvolvimento de todas as funções que ainda não amadureceram na criança. De sorte que, quando dizemos que a aprendizagem deve apoiar-se na zona de desenvolvimento imediato, nas funções ainda não amadurecidas, não estamos propriamente passando uma nova receita para a escola, mas simplesmente nos libertando do velho equívoco segundo o qual o desenvolvimento deve necessariamente percorrer os seus ciclos, preparar inteiramente o solo em que a aprendizagem irá construir o seu edifício. (VIGOTSKI, 2007, p. 332)
\end{abstract}

Nesse sentido, compreendemos que esses novos materiais de verificação, em semelhança com a antiga avaliação enviada, ao permanecerem como instrumentos que se orientam para o ontem, suscitam a equivocada concepção de que o estudante precisa ter "certas funções amadurecidas" como requisito para o desenvolvimento de outras. Com isso, tais instrumentos, utilizados como principais ferramentas em relação ao planejamento do professor e da escola, como um todo, perdem sua relevância por não serem capazes de revelar nada substancialmente novo sobre o curso do desenvolvimento da criança.

Em acordo com Vigotski (2001), o ensino fecundo, que possibilita a passagem do pensamento empírico para o teórico, deve orientar-se na necessidade de colocar a criança acima de si mesma, exigindo sempre mais do que ela pode dar hoje. Isso não significa ensinar aquilo que ela não é capaz de aprender, tampouco ensiná-la a fazer o que ela já faz sozinha, uma vez que

uma criança analfabeta em um grupo de crianças alfabetizadas irá atrasar-se em seu desenvolvimento e em seu aproveitamento relativo tanto quanto uma criança alfabetizada em um grupo de não-alfabetizados, embora para uma 0 avanço no desenvolvimento e no aproveitamento seja dificultado pelo fato 
de que, para ela, a aprendizagem é difícil demais, enquanto é fácil demais para outra. (VIGOTSKI, 2001, p. 336)

Diante disso, os meios didáticos utilizados pelos docentes para organização do ensino que possibilite à criança a apropriação dos processos que levam à aprendizagem devem realizar-se dentro da zona de desenvolvimento imediato, não acima ou abaixo dela, mas de modo que, em colaboração, o estudante passe do que sabe para o que virá a saber (VIGOTSKI, 2001).

Nosso segundo ponto de análise diz respeito à possibilidade de superação do sistemático controle externo à sala de aula, oportunizando às escolas e a seus professores maior independência para organização, planejamento, realização e avaliação de sua atividade de ensino.

Entretanto, concordamos com Esteban (2002, p. 13) no que diz respeito a esta outra perspectiva em que, sem critérios sobre o que avaliar, as mudanças podem incorrer apenas em modos superficiais, ou seja:

[...] outra perspectiva tem como objetivo romper com o controle de segregação, mas ainda não encontrou os aspectos chaves que devem ser transformados, por isso propõe modificações superficiais, ainda que aparentemente indiquem mudanças profundas.

Há de se ressaltar que, com esta pesquisa, não estamos propondo modos ou meios para que o ensino se organize sem critérios que oportunizem, assim como descreve Moura et al. (2010), as condições necessárias de análise e síntese da relação ensino-aprendizagem, mas modos e meios para que, longe da responsabilização dos modelos avaliativos externos às escolas - não, simplesmente, pelo fato de serem preparados por aqueles que estão fora dos muros escolares, mas, principalmente, por não reproduzirem modelos avaliativos que se assemelham a simuladores preparatórios que priorizam o domínio de habilidades voltadas aos conceitos memorizados (FREITAS, 2014) -, os professores possam se apropriar de todas as etapas que compõem a organização do ensino, como o planejamento, a concretização e a avaliação de seu trabalho: a atividade de ensino (MORAES, 2008).

Nesse sentido, entendemos que, ao apropriar-se das condições objetivas para efetivação da atividade de ensino, as relações humanas presentes nos processos de elaboração dos conceitos poderiam romper com o modelo de 
ensino que parte do currículo e volta para o currículo, para um modelo em que o ensino parta do sujeito e retorne ao sujeito, "como forma de transformar as necessidades individuais em coletivas" (MORAES, 2008, p. 100), e, com isso, possibilitar que a necessidade humana que, outrora, deu origem à construção dos conceitos, possa ser recuperada pelo estudante por meio de situações desencadeadoras contidas na Atividade Orientadora de Ensino (MOURA et al., 2010), uma vez que, por indicar uma necessidade, um motivo, objetivos, e propor ações que considerem as condições objetivas para efetivação do trabalho docente, de acordo com Moura (2010), assemelha-se à Atividade, a qual defendemos, a partir do exposto por Leontiev (2004, p. 283, grifos nosso):

\begin{abstract}
Pela sua atividade, os homens não fazem senão adaptar-se à natureza. Eles modificam-na em função do desenvolvimento de suas necessidades. Criam os objetivos que devem satisfazer as suas necessidades e igualmente os meios de produção desses objetos, dos instrumentos às máquinas mais complexas. Constroem habitações, produzem as suas roupas e outros bens materiais. Os progressos realizados na produção de bens materiais são acompanhados pelo desenvolvimento da cultura dos homens; o seu conhecimento do mundo circundante deles mesmos enriquecem-se, devolvem-se a ciência e a arte.
\end{abstract}

Nesse movimento, entendemos que "adaptação" corresponde ao oposto da passividade que negligencia as necessidades humanas, mas busca transformar os sujeitos à medida que novas necessidades exigem novas ações e novas operações para satisfazê-las, pois "a criança [e o adulto] não se adapta ao mundo dos objetivos e fenômenos humanos que a rodeiam, fá-lo seu, isto é, apropria-se dele" (LEONTIEV, 2004, p. 340, grifo do autor).

Assim, a avaliação dialética, na relação ensino-aprendizagem, como um processo contínuo de apropriação e significação, "constitui-se parte inerente do planejamento e da atividade, tendo em vista que essa se concretiza no processo de análise e síntese da relação entre a atividade de ensino do professor e a atividade de aprendizagem do estudante" (MOURA et al., 2010, p. 224), possibilitando aos sujeitos condições de transformação, ao passo que, em atividade, superam a reprodução mecânica presente no ensino que se baseia pelos resultados decorrentes dos diferentes instrumentos voltados à verificação de respostas (frequentemente memorizadas) como sinônimo de autonomia intelectual. 
Um exemplo desta apropriação e significação verificamos no movimento de elaboração e aplicação de um instrumento que, contrariamente à avaliação que se configura como instrumento utilizado para diagnosticar, tinha por objetivos aproximar os sujeitos envolvidos na relação ensino-aprendizagem, fortalecer os vínculos entre a escola e as famílias, bem como ouvi-las e auxiliar na mediação de ações diante do novo quadro educacional (ASSIS, 2020), em que o ensino remoto se instalou no Brasil, como medida protetiva diante da pandemia Covid-19. Com seus primeiros casos na cidade de Wuhan, na China, em meados de dezembro de 2019, espalhou-se pelo mundo e colocou-nos em situação de distanciamento social, em acordo com as orientações da OMS (Organização Mundial de Saúde), desde março de 2020.

Diante deste acometimento, o GEPEAMI, em conjunto com professores e integrantes do Núcleo Pedagógico da Secretaria Municipal de Educação do município campo, iniciou um processo de discussões e análises acerca dos diferentes aspectos que compõem os modos de organização do ensino na modalidade não presencial, permitindo-nos revisitar os princípios do documento curricular que, em processo de elaboração, vinha sendo escrito de modo colaborativo entre membros do grupo e do Núcleo Pedagógico da Secretaria Municipal de Educação, e, para além da formação do cidadão, trazia como gênese o desenvolvimento humano.

Nesse sentido, diante deste novo quadro, Assis (2020, p. 68), relata:

Muitos foram os aspectos discutidos acerca das atividades não presenciais e pensamos em criar um instrumento destinado às famílias para que pudessem relatar suas impressões e sentimentos em relação às atividades remotas (facilidades e dificuldades, pontos positivos e negativos).

Fruto deste movimento, uma entrevista ${ }^{12}$ foi elaborada pela professora e enviada às famílias, para que, em conjunto com seus filhos, escrevessem suas impressões, opiniões e até mesmo angústias acerca das atividades enviadas durante o período de aulas remotas devido às medidas de afastamento social.

Esta entrevista, apesar da aparente semelhança com os habituais instrumentos utilizados para verificação das aprendizagens, traz em sua

\footnotetext{
${ }^{12} \mathrm{O}$ modelo da entrevista enviada às famílias foi compilado no Anexo 4 desta pesquisa.
} 
essência nova qualidade e novo significado, uma vez que avança do velho modelo avaliativo para configurar-se como meio de análise e reflexão das condições objetivas dos estudantes e, mesmo sob medidas de distanciamento, possam se manter em atividade. Como explica Leontiev (2004, p. 341), esse é um processo de apropriação das aquisições do desenvolvimento das gerações precedentes, que não chegam ao sujeito que aprende morfologicamente ou por meio hereditário, mas se dão no decurso em que as relações com o mundo são "mediatizadas pelas suas relações com os homens".

Este movimento, possibilitado por uma avaliação que se configura como ação inerente à atividade educativa, permitiu e possibilitou uma dinâmica formativa de regulação das práticas de ensino, em que a professora, para além da pseudointencionalidade pedagógica, partindo das colocações das famílias, organizou situações ensino que pudessem mobilizar nos sujeitos a necessidade de se colocarem em atividade de estudo. Temos, então, uma avaliação que sai do sujeito e retorna ao sujeito.

Como um organismo vivo e que, para a vida, se encontra não na formação do cidadão com vistas à manutenção da sociedade, em que o sujeito passivamente se adapta às condições dadas, à educação como prática libertadora (FREIRE, 2005) que parte e retorna para o sujeito, sem excluí-lo, classificá-lo ou responsabilizá-lo pela métrica em que a avaliação se atrela à meritocracia e provoca a ascensão de poucos e a exclusão de muitos. Mas que, ao contrário, possibilite, sobretudo, condições em que 0 ato avaliativo se situe na dimensão dialética que compreende todas as etapas da relação ensinoaprendizagem, possibilitando consciência acerca das possibilidades de apropriação da cultura humana.

Desse modo, tirar a avaliação de seu espaço de medição retrospectiva da aprendizagem significa qualificá-la na perspectiva da mediação, isto é, que mediatiza a relação entre a herança cultural e os homens, pelo movimento dialético que impulsiona e permite aos sujeitos condições objetivas de regulação entre o ensino e a aprendizagem, de modo a possibilitar a apropriação "dos caracteres, faculdades e modos de comportamento humanos formados historicamente" (LEONTIEV, 2004, p. 340).

Nesse sentido, a mediação, sob a ótica que temos defendido na avaliação dialética, objetiva-se apenas por meio da atividade de ensino, em que o professor 
compreende que, apesar de os bens culturais serem garantidos aos sujeitos pelo "direito à aprendizagem", esse direito não necessariamente garante aos herdeiros condições para que possam se apropriar, razão pela qual temos defendido o direito à educação.

Trazer "ao nível do homem comum o patrimônio cultural comum" (CARAÇA, 2010, p. x, grifos do autor) representa mais do que uma aproximação entre os sujeitos em aprendizagem e os conceitos que thes são apresentados. O verbo "trazer" nesta oração, significa, para nós, a possibilidade de concretização de uma atividade de ensino, em que a avaliação avança da dimensão instrumental e operacional, cuja "naturalização" Ihe concede a função de diagnosticar os "avanços" dos estudantes, para ser assumida como conteúdo e forma reguladora da totalidade da atividade.

Nesse sentido, ao afirmarmos que avaliar constitui-se como açãoinstrumento inerente à atividade humana e, por isso, inerente à atividade de ensino, nós o fazemos considerando a atividade que, intencionalmente organizada, garante o direito à educação que "traz" aos sujeitos condições para que tomem posse dos bens culturais. 


\section{A AVALIAÇÃO DIALÉTICA: DA MEDIÇÃO À MEDIAÇÃO}

Ao longo de nossas discussões, temos defendido a escola como "instituição privilegiada" (RIGON; ASBAR; MORETTI, 2016, p. 33), no que se refere ao espaço construído socialmente, com a finalidade específica de organizar o ensino, por acreditar que, desse modo, seria possível dar às gerações acesso de forma mais objetiva ao patrimônio cultural construído pela humanidade (MOURA; ARAUJO, 2018).

Nesse sentido, pesquisas acerca dos preceitos teóricos e metodológicos que se configurem como orientadores dessa organização tornaram-se objeto de estudo para três gerações de pesquisadores, a partir da Atividade Orientadora de Ensino (AOE), defendida por Moura em sua tese de doutorado, em 1992 (PIOTTO, 2020).

Em publicações recentes, Moura e Araujo (2018), Moura, Sforni e Lopes (2017), Piotto (2020) e outros pesquisadores, têm destacado a AOE como um modo de organização "intencional" do trabalho educativo, o qual, como uma base teórico-metodológica, possibilita que a realização da atividade docente mobilize no estudante a realização da atividade de aprendizagem, constituindo-se como mediadora entre o ensinar e o aprender.

Portanto, ao defendermos a concepção de avaliação como ação intrínseca ao movimento de ensino e aprendizagem, analisar os nexos que ligam a Avaliação Dialética à Atividade Orientadora de Ensino, tornou-se fundamental para a conclusão desta pesquisa, pois buscamos superar a concepção que a engloba, única e somente, como um instrumento que, ao ser operacionalizado adequadamente, configura-se como verificador (externo ou, mesmo, interno às salas de aula) das aprendizagens conquistadas pelo estudante (FREITAS, 2014).

Desse modo, significá-la coloca-se como necessário diante da tese vigotskiana que temos defendido, de que o ensino, intencionalmente organizado, "deve orientar-se não no ontem, mas no amanhã do desenvolvimento da criança" (VIGOTSKI, 2001, p. 333); em outras palavras, assumir a avaliação como mediadora entre o que ela sabe e o que virá a saber traz nova qualidade ao seu papel na organização do ensino. 
Neste capítulo, abordaremos brevemente os preceitos da Atividade Orientadora de Ensino a partir da concepção que a compreende como base teórico-metodológica para organização intencional da atividade realizada pelo professor, buscando, nesse movimento, estabelecer relações entre a Avaliação Dialética tal qual temos defendido e a Atividade Orientadora de Ensino.

Para isto, daremos ênfase a três momentos da atividade do professor: 0 antes, o durante e o momento após a atividade pedagógica, indicando a Avaliação Dialética como mediadora das ações realizadas pelo professor na atividade de ensino que tenha como objetivo recuperar, mesmo que em outra proporção, a experiência humana que possibilite aos sujeitos condições que se apropriem de conhecimentos que ainda não Ihes pertencem (MOURA; ARAUJO, 2018; PIOTTO, 2020).

Para discutirmos sobre essas ações, neste capítulo, inicialmente, abordaremos os preceitos da Atividade Orientadora de Ensino, como base teórico-metodológica para os sujeitos envolvidos na relação ensinoaprendizagem, ancorando-nos, principalmente, nos princípios da teoria da atividade (LEONTIEV, 2004), além de outros autores que, por sua vez, possam auxiliar na significação do nosso objeto: a avaliação dialética como unidade mediadora entre o ensinar e o aprender.

Em seguida, iremos discutir e analisar em que medida a avaliação dialética, da forma como temos defendido, pode ser compreendida como ação intrínseca à atividade pedagógica, concentrando-nos na atividade docente, a qual, para nós, é objetivada em três principais ações que se interdependem: planejamento, realização e desfecho da atividade pedagógica.

Finalizaremos essa discussão, apresentando uma possibilidade de continuidade para a "cena" iniciada no primeiro texto deste capítulo, no qual nossa intenção é apresentar o movimento em que a avaliação dialética objetivada em cada uma das ações da atividade de ensino cria condições, para que, de modo intencional, o professor faça da escola, de fato, um espaço privilegiado de apropriação do conhecimento (RIGON; ASBAR; MORETTI, 2016). 


\subsection{A relação entre a Avaliação Dialética e a Atividade Orientadora de} Ensino

Imaginemos a seguinte situação: em casa, a criança organiza seu material escolar, coloca-o na mochila, despede-se da mãe e caminha em direção à escola. Seu pensamento saltita entre a alegria de encontrar os amigos e ver a professora. Ao passar pelo portão de entrada, corre para quadra, onde muitos brincam com bola, e espera o sinal. Vai para fila, caminha até a classe, organizase na carteira e aguarda ansiosamente o momento em que a aula irá começar... Sem conseguir esperar, pergunta: "Tia, o que vamos fazer hoje?".

As experiências vivenciadas por aqueles que trabalham com educação, comumente, mostram-nos que, muitas vezes, uma cena como essa não se desenrola com tanta leveza e espontaneidade, pois alguns são empurrados para dentro dos portões ou, ainda, não possuem materiais que possam organizar. Uma rápida busca pelos veículos de comunicação e informação mostra-nos que, no Brasil, mesmo antes da pandemia, já contávamos 51,7 milhões de pessoas abaixo da linha da pobreza definida pelo Banco Mundial (ANTES DA..., 2020).

Além disso, há também aqueles que não se despedem de ninguém, apenas saem de uma casa silenciosa, trancam a porta e, presa a uma corrente, penduram a chave no pescoço para não a perder ao longo do dia.

Entretanto, essa mesma experiência indica que, mesmo diante de tantas complicações, não foram poucas as vezes em que uma pergunta como aquela, de um sujeito inquieto, foi feita em uma sala de aula.

Neste momento, é provável que o leitor esteja se perguntando qual a relevância dessa introdução, uma vez que o título aponta para uma discussão sobre a relação entre a Atividade Orientadora de Ensino e o objeto desta pesquisa.

O caminho mais lógico que escolhemos para tratar dessa relação parte do que explica Leontiev (2004) sobre os equívocos das análises feitas por diferentes autores contemporâneos que, na tentativa de explicar o "conceito de sentido", iniciam seus estudos pelos fenômenos pertencentes ao campo da consciência, e por esse motivo, acabam sempre permanecendo presos a ela: 
A consciência não pode ser compreendida a partir de si própria. $O$ estudo genético, histórico da consciência comporta toda uma outra démarche. Ela não parte da análise dos fenômenos da tomada de consciência, mas dos fenômenos da vida, característicos da interação real, que existe entre o sujeito real e o mundo que o cerca, em toda objetividade $e$ independentemente de suas relações, ligações $e$ propriedades. Razão por que num estudo histórico da consciência, o sentido é antes de mais nada uma relação que se cria na vida, na atividade do sujeito. (LEONTIEV, 2004, p. 103)

Nessa direção, não poderíamos tratar da relação entre a Atividade Orientadora de Ensino (AOE) e a Avaliação Dialética (AD) do mesmo modo que levou os autores contemporâneos incorrerem no equívoco discutido por Leontiev (2004), em que, encerrados nos fenômenos do próprio objeto, não conseguiam avançar em direção à compreensão que buscavam sobre o conceito.

Desse modo, para compreendermos a relação entre nosso objeto, a Avaliação Dialética, e a Atividade Orientadora de Ensino, faz-se necessário retomar alguns pontos desta pesquisa que nos levam a discutir em que medida os preceitos da Avaliação Dialética alinham-se aos princípios teóricometodológicos da Atividade Orientadora de Ensino e possibilitam, aos sujeitos envolvidos, condições para que se apropriem dos conhecimentos construídos pela humanidade.

Charlot (1979), ao apresentar os princípios subjacentes à pedagogia social, assim como discutimos anteriormente, busca subtrair dos sujeitos a condição hierárquica em relação ao papel que ocupam no espaço escolar, em que, tanto para pedagogia tradicional como para pedagogia nova, ora 0 professor, ora o estudante, são considerados inferiores ou superiores em relação ao outro. Com efeito, como "parceiros sociais", participam igualmente da relação ensino-aprendizagem como sujeitos que possuem possibilidades de transformar-se, ao passo que transformam o outro e o meio.

Isso se dá, uma vez que o desenvolvimento, definido por Vigotski (2001) como o surgimento do novo, possibilita uma mudança no psiquismo que, como Moura e Araujo (2018) explicam, leva a uma mudança nas condições de análise do objeto e, em consequência, a uma mudança no modo como agem sobre ele.

De modo semelhante ao que compreendemos em Charlot (1979) sobre a exclusão hierárquica e a inclusão de ambos em uma relação coletiva, mediada socialmente, tanto Vigotski (2001) como Leontiev (2004) afirmam que é na 
relação entre a criança e o adulto que correm as possibilidades de desenvolvimento das funções psicológicas que conduzem o surgimento do novo.

Em síntese, elas surgem logo nos primeiros contatos entre a criança e os parceiros mais experientes no início de sua vida, ao passo que os conceitos do mundo circundante são mediatizados para apropriação, assim como no exemplo da criancinha, quando se apropria de algo tão simples como a colher. Inicialmente, ao tê-la nas mãos, manipula-a do ponto de vista de suas propriedades físicas, naturais e não específicas, mas, com a ajuda da mãe ou da ama, que alimentam a criança com a colher e intervêm em suas ações, formase "na criança o hábito de utilizar a colher. Ela sabe doravante manejar a colher como um objeto humano" (LEONTIEV, 2004, p. 342, grifo do autor).

Assim como esta apropriação é importante para o convívio da criança em seu círculo social, uma vez que este hábito não corresponde ao modo com que as pessoas, em todas as culturas, utilizam para se alimentar, quando a criança atinge a idade escolar, outros conhecimentos também necessitam ser mediatizados, pois no círculo familiar a mediação entre a criança e os conceitos ocorre espontaneamente, de forma não intencional.

Moura et al. (1996) destaca que, na relação familiar, os conceitos são apresentados à criança em sua forma acabada, ou seja, apenas em seu estado final e, portanto, sua apropriação não promove o desenvolvimento dos nexos próprios do pensamento teórico (DAVIDOV, 2017).

Nesse sentido, partimos da tese apresentada por Charlot (1979) para salientar que, no espaço escolar, a atividade exercida pelo professor, bem como a exercida pela criança não se situam hierarquicamente, em posições diferentes, caracterizadas como superiores ou inferiores, mas, sobretudo, diferenciam-se pela qualidade de cada uma na relação ensino-aprendizagem.

Ao professor cabe a vital necessidade de organizar o "meio educativo social" (VIGOTSKI, 2003, p. 77), ou seja, a ele cabe pensar suas intervenções pedagógicas para que o conhecimento construído pelas gerações, diante da pergunta: “Tia, o que vamos fazer hoje?", não recaia somente sobre o conteúdo curricular que, estruturado ao material didático, configure-se como o orientador da resposta: "Hoje vamos estudar sobre as horas!".

Se ao professor está claro que sua a atividade corresponde ao ensino, certamente ao estudante corresponderia a atividade de aprendizagem. 
Entretanto, Moura e Araujo (2018) afirmam que nesta atividade há apenas a suposição de que o estudante compreende o papel da escola e a relevância daquilo que está sendo ensinado, de modo que, por si só, o sentido particular que o mobiliza na realização de sua atividade poderia estar relacionado à necessidade de cumprir a tarefa para receber uma nota, assim como no exemplo apresentado por Leontiev (2004) sobre o estudante que, após receber a visita de um camarada que lhe informa que o livro que está lendo não é o necessário para preparar-se para o exame, imediatamente deixa-o de lado e abandona a leitura.

Todavia, o professor, ao manejar os meios necessários para concretização de seu trabalho, encarrega-se de atribuir significados àquele que aprende, possibilitando-lhe a construção de sentidos para além da necessidade advinda da nota (MOURA; ARAUJO, 2018), como no caso do sujeito que, informado sobre a irrelevância da atual leitura para preparar-se para o exame, opta por continuar a ler o livro, uma vez que a apropriação do seu conteúdo é que satisfaz diretamente sua necessidade particular (LEONTIEV, 2004).

A necessidade de saber, elucidar e compreender aquilo que o livro fala corresponde à necessidade de resolver os problemas propostos pelo professor diante de situações desencadeadoras de aprendizagem.

Neste ponto reside a relação entre a Avaliação Dialética e a Atividade Orientadora de Ensino. Avaliar dialeticamente, ao longo da atividade que oriente para o ensino, em semelhança à analogia apresentada por Marx (2006) sobre a principal diferença entre a execução de uma tarefa pelo homem e pelo animal é que, na objetivação da AOE, a Avaliação Dialética está antes na mente do professor, como instrumento psicológico que lhe possibilita a capacidade de análise e síntese de sua atividade, mesmo antes dela ocorrer.

Nas palavras de Marx (2006, p. 2011),

uma aranha executa operações semelhantes às do tecelão, e a abelha supera mais de um arquiteto ao construir sua colmeia. Mas o que distingue o pior arquiteto da melhor abelha é que ele figura na mente sua construção antes de transformá-la em realidade. No fim do processo do trabalho aparece um resultado que já existia antes idealmente na imaginação do trabalhador.

Desse modo, a avaliação, compreendida em sua dimensão dialética, concretiza-se mediante o planejamento, a realização e o desfecho de uma 
atividade pedagógica firmada na concepção da Atividade Orientadora de Ensino. A Avaliação Dialética, nesse sentido, envolve ações que se orientam ao longo de todo o processo, em que o professor define e organiza instrumentos e modos de ação e operação que Ihe possibilitem a realização de seu trabalho. Ao realizálo, analisa se as ações o direcionam na satisfação de sua necessidade que, em suma, é movida pelo objetivo de ensinar os conceitos e possibilitar que o estudante deles se aproprie (MORAES, 2008; MOURA et al., 2010; MOURA; ARAUJO, 2018) e, ao concluir, avalia se atingiu ou não os objetivos tais como os idealizou (MOURA; ARAUJO, 2018).

Moura, Sforni e Lopes (2017, p. $79-80)$ afirmam ainda que

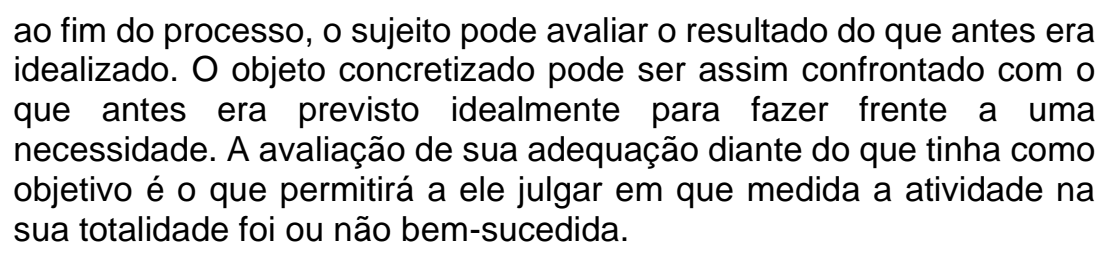

Nesta relação, a qualidade daquilo que foi produzido por meio das ações e operações dos sujeitos é que Ihes possibilitará parâmetros para julgar a qualidade da atividade em sua composição total, permitindo desta forma a busca por novas metas que, para satisfazer novas necessidades, exigirão, sempre que necessário, novas ações (MOURA, 2000).

A tese vigotskiana que anteriormente abordamos para analisar a relação entre aprendizagem e desenvolvimento, em que o autor afirma que "aprendizagem não é desenvolvimento, mas corretamente organizada, conduz 0 desenvolvimento mental da criança, suscita para a vida uma série de processos que, fora da aprendizagem, se tornariam inteiramente inviáveis" (VIGOTSKI, 2010, p. 484, grifo nosso), corrobora para que continuemos a tratar da relação entre nosso objeto e os princípios teórico-metodológicos presentes na Atividade Orientadora de Ensino.

Isso, porque, ao destacarmos a Avaliação Dialética como unidade mediadora que direciona o professor para a concretização de ações e operações que, por sua vez, possibilitam o desenvolvimento do seu trabalho, consideramos que este apenas se realiza mediante a apropriação da experiência humana (MOURA et al., 2010): evidenciada, na atividade do educador, pela formação da 
consciência sobre todas as etapas que envolvem a organização do ensino (MORAES, 2008) e, na atividade do educando, pela apropriação dos conceitos partilhados em situações sociais coletivas, por meio das quais o ensino, intencionalmente organizado, objetiva-se na formação dos conceitos presentes no pensamento teórico (DAVIDOV, 2017), cuja essência não pode ser reduzida aos conhecimentos do meio circundante, assim como vemos na resposta "Hoje vamos estudar sobre as horas!".

Há de se ressaltar que, se compreendemos que a condição para que os sujeitos se coloquem em atividade é a consciência sobre os modos de apropriação do conhecimento e sobre os modos intencionais de organização para tornar esta apropriação mais eficaz, entenderemos que a tomada de consciência sobre a importância da organização das atividades para os processos de formação do pensamento teórico, como funções psicológicas, pode, por sua vez, potencializar os modos de ação dos sujeitos, fortalecendo o surgimento de neoformações no desenvolvimento psíquico (MOURA; SFORNI; LOPES, 2017).

Nessa direção, em casa, com a família, é provável que o estudante tenha participado de situações em que, por algum motivo, tenha sido convidado a consultar as horas ou, ainda, tenha tido a necessidade de arrumar-se rápido, por estar atrasado para algum compromisso. O conceito de hora, neste caso, aparece como um elemento cultural já construído (MOURA et al., 1996) e inserido nas atividades diárias comuns a tantos espaços. Em sala de aula, retomar este elemento, do mesmo modo como ele se coloca para a criança no seio familiar ou nos espaços sociais que ocupa não sobrepuja o pensamento próprio da prática cotidiana.

\footnotetext{
Esse pensamento tem um caráter classificador e catalogador, que garante a orientação da pessoa no sistema de conhecimentos acumulados referentes às particularidades e características externas de objetos e fenômenos, sem relação com a natureza e sociedade. Tal orientação é indispensável para os afazeres cotidianos durante o cumprimento de ações laborais rotineiras, mas é absolutamente insuficiente para assimilar 0 espírito autêntico da ciência contemporânea e os princípios de uma relação criativa, ativa e de profundo conteúdo no que concerne à realidade (tal relação supõe a compreensão das contradições internas das coisas, ignoradas precisamente pelo racionalismo empírico) (DAVIDOV, 2017, p. 212213).
} 
Moura, Sforni e Lopes (2017) destacam que os conceitos teóricos não são assimiláveis pelos sujeitos em uma relação direta que envolve sua participação nas atividades práticas nas quais eles estão inseridos, como no exemplo da criança e sua relação cotidiana com a consulta das horas e o controle do tempo. Por outro lado, é preciso que haja uma atividade específica, intencionalmente planejada e direcionada a este fim: favorecer que "os conhecimentos compartilhados na concretização de algo tomado como relevante constituam o significado. O conceito surge desse processo de forma viva e significativa" (MOURA; SFORNI; LOPES, 2017, p. 73).

O ensino intencionalmente organizado deve mobilizar ações e operações que, por sua vez, têm a finalidade de satisfazer as necessidades que se apresentam ao estudante e criam nele um motivo pessoal para realizá-las. Em outras palavras, o ensino configura-se "sob formas de ações exteriores, que o adulto forma na criança e em seguida, apenas são transformados em operações intelectuais interiores" (LEONTIEV, 2004, p. 350).

Nesse sentido, os preceitos subjacentes à Atividade Orientadora de Ensino, mediados pela Avaliação Dialética, revelam-se na articulação entre a teoria e a prática, constituindo-se, na práxis pedagógica, como uma atividade mediadora entre a atividade de ensino, do professor, e a atividade de aprendizagem, do estudante (MUNHOZ; MOURA, 2019), mantendo uma dinâmica que, assim como afirma Piotto (2020, p. 337), permite aos sujeitos "recriar situações que, na história da humanidade, geraram uma necessidade real cujo atendimento resultou na produção de um determinado conceito".

Nessa dinâmica, em lugar de: "Hoje vamos estudar sobre as horas!", a resposta do professor deveria ser aquela que suscita no estudante uma "tensão criativa" (LANNER DE MOURA, 2002) que, em afinidade com a vivenciada pela humanidade em seu processo histórico de criação dos conceitos, corresponde à "situação desencadeadora de aprendizagem" que mobiliza no estudante a necessidade de aprender (MOURA; ARAUJO, 2018).

Tal mudança, mais do que uma simples alteração de frases, desencadeia a construção de sentidos que, para professor e estudante, adquirem nova qualidade no ensino orientado por habilidades que preveem como essencial a aprendizagem da leitura e do registro de horas em relógios digitais ou 
analógicos, assim como da leitura e do registro de medidas e intervalos de tempo em horas, minutos e segundos (BRASIL, 2017).

De fato, controlar o tempo ou "a cronologia" corresponde a uma das necessidades mais antigas da humanidade - desde o Período Paleolítico, quando a observação da posição e da periodicidade dos astros contribuía para que os caçadores fossem bem-sucedidos na caça e na pesca, até os dias atuais, em que uma vasta gama de conhecimentos sobre o estudo do tempo possibilitou-nos referir aos seus sucessivos movimentos por nomes, como dia, noite, primavera, verão e tantos outros. E mostrou-nos que, ao longo da história da humanidade, as civilizações sempre buscaram formas de controlar o tempo para gerir e organizar suas atividades e sua vida (MOURA et al., 2019):

[...] Para muitas pessoas, o tempo se afigurava um fluxo não
fracionado. Assim, os experimentadores e inventores passaram
séculos tentando medi-lo, imitando sua passagem contínua, isto é, o
fluxo da água, de areia, de mercúrio, de porcelana moída, e assim por
diante - ou a combustão lenta e regular de uma vela longe do vento.
Mas ninguém jamais concebera um modo prático de medir períodos
longos por esses meios. A substância em movimento tornava-se
gelatinosa, congelava, evaporava ou se coagulava, ou então a vela
queimava num ritmo perversamente rápido ou perversamente lento, ou
então se derretia - alguma coisa saía errada. A solução do problema
tornou-se possível quando se parou de pensar no tempo como um
continuum regular e se começou a pensar nele como uma sucessão
de quantidades. (CROSBY, 1999, p. 85)

Desse modo, como resposta a uma necessidade social, a humanidade construiu meios de controle para que tivéssemos, assim como o domínio do fogo, o "domínio do tempo". E, como produto da herança cultural, para dominá-lo, mais do que ensinar formas de medi-lo, cabe aos sujeitos criar condições para que as próximas gerações possam também vir a se apropriar desse conhecimento que, de objeto da atividade humana, tornou-se objeto da atividade de ensino.

Apropriar-se, nesse sentido, significa constituir-se de sentidos coletivos, tornando-os pessoais, de forma que o professor e o estudante passam da condição de "depositário e depositante" (FREIRE, 1987) para sujeitos da atividade pedagógica que, como explicam Moura e Araujo (2018), mudam de qualidade ao passo que interagem, transformando dialeticamente a si, ao outro e à forma com que analisam e atuam sobre o meio. 


\subsection{A Avaliação Dialética na atividade de ensino}

Ao iniciarmos a construção de significações que, assim como explica Leontiev (2004, p. 101), é "a forma sob o qual um homem assimila a experiência humana generalizada e refletida", passamos a compreender o conceito de avaliação a partir da perspectiva que o engendra como elemento intrínseco ao sujeito e, em consequência, à atividade de ensino e de aprendizagem, não como elemento natural, mas que, ao ser produzido socialmente, constitui-se "parte" da atividade que torna o sujeito humano. Nesse sentido, fazemos uso das palavras de Moraes (2008, p. 241, grifo nosso) para explicar que, nesse processo, a avaliação é assumida como

[...] mediadora entre a atividade de ensino elaborada pelo professor $\mathrm{e}$ a atividade de aprendizagem realizada pelo aluno, fornecendo elementos para esclarecer e orientar o processo de ensino e aprendizagem. Seu parâmetro fundamental são os conhecimentos teóricos necessários à formação humana dos sujeitos envolvidos no processo educativo. A avaliação sob esta ótica, é uma ação inerente à atividade pedagógica e reguladora desta atividade.

Diante disso, ao passo que esse modo de conceber o conceito de avaliação também tem sido assumido por nós ao longo desta pesquisa, faz-se necessário destacarmos que a concepção de "ação" que temos defendido se refere ao conceito explicado por Leontiev (2004), em que, ao tratar da Teoria da Atividade, o autor esclarece o pertencimento desta particularidade à totalidade da atividade humana.

Para explicarmos nossa compreensão desse conceito e o modo como ele se relaciona à Avaliação Dialética, retomaremos o exemplo da caçada coletiva, em que o autor explica que para cada participante são distribuídas ações que, de modo geral, não coincidem com o motivo coletivo da atividade que, neste caso, é representado pela necessidade de abater a caça. Todavia, o motivo coletivo se realiza no sentido pessoal para cada indivíduo, de forma que, internamente, são estimulados a realizar as ações que lhes cabem pela necessidade particular de alimentar-se em ou vestir-se.

Ainda em relação ao exemplo da caçada coletiva, o autor explica que assustar a caça, orientando-a na direção dos outros caçadores, ou abatê-la são ações que, diretamente, não correspondem à satisfação da necessidade pessoal 
dos sujeitos envolvidos, pois, de modo geral, as ações são "processos que o objeto e o motivo não coincidem" (LEONTIEV, 2004, p. 82). Entretanto, mesmo não coincidindo, constituem-se como elementos fundamentalmente necessários para realização da caçada como um todo, pois, sem a realização de uma dessas ações, a caçada poderia não se concluir (MOURA; SFORNI; LOPES, 2017).

Do mesmo modo, a avaliação na atividade pedagógica, sob a ótica que temos defendido, não está diretamente direcionada para o motivo da atividade, objetivada pela apropriação dos conhecimentos construídos historicamente pelo homem, mas se revela como parte do todo, uma vez que sua dimensão dialética possibilita condições de análise e síntese dos aspectos pedagógicos e psicológicos que se encontram entre o ensinar e o aprender (MORAES, 2008; MOURA et al., 2010).

A avaliação, nesse movimento, passa a se constituir como movimento contínuo de mediação da atividade de ensino e da atividade de aprendizagem, que ocorrem de modo intencional ao longo da atividade pedagógica, situandose para além das condições observáveis, dadas pela avaliação em sua dimensão instrumental e operacional, que, assim como discutimos anteriormente, configuram-na como instrumento operacionalizado a favor da pseudointencionalidade pedagógica, como "fechamento do processo ou verificação da qualidade do processo ocorrido" (FREITAS, 2014, p. 1088).

Moura e Araujo (2018), ao tratarem dos princípios teórico-metodológicos da Atividade Orientadora de Ensino, destacam que o termo "orientadora" está relacionado à consciência do professor sobre o fato de que, ao objetivar sua atividade, poderá não atingir os objetivos, tais como idealizou, pois, pelo fato de lidar com outros sujeitos, ou seja, com aqueles que se encontram em atividade de aprendizagem, lida com personalidades singulares.

Assim, a aprendizagem, objetivada idealmente no planejamento do professor, será apropriada por cada sujeito de acordo com as potencialidades cognitivas, afetivas e físicas que, por motivos ímpares, são desencadeadas pelas ações e operações do educador, ao propor situações de ensino. Tal apropriação configura-se como particular e pessoal, transformando aquilo que antes carregava um sentido pessoal em algo que, agora, responde a um sentido coletivo (MOURA; ARAUJO, 2018). 
Diante disso, importa-nos discutir em que medida a Avaliação Dialética, ao longo da atividade de ensino fundamentada pelos preceitos teóricometodológicos da $\mathrm{AOE}$, pode desencadear nos sujeitos motivos para que se coloquem em atividade de aprendizagem.

Para essa análise, decidimos separar a atividade de ensino em três ações que, apesar de não coincidirem diretamente com o motivo da atividade de ensino, relacionam-se, para que sejam criadas condições para que os sujeitos possam se apropriar do conhecimento construído pela humanidade.

A primeira ação diz respeito ao planejamento da atividade de ensino. $\mathrm{E}$ para sua análise, inicialmente, trataremos da influência e da orientação advindas das avaliações externas, dos livros didáticos e das propostas curriculares dos governos, discutindo seus papéis no que se refere aos modos de organização da atividade de ensino com vistas (ou não) ao desenvolvimento do pensamento teórico, destacando a Avaliação Dialética, como "ação" avaliativa.

Em relação à segunda ação, ao abordarmos a realização da atividade de ensino, discutiremos a Avaliação Dialética, no movimento de análise e síntese, para regulação das operações realizadas pelo professor, com vistas à objetivação de sua atividade, ou seja, na regulação de práticas e condutas que coloquem o estudante em atividade de aprendizagem.

Por fim, a terceira ação, ao tratar do desfecho da atividade de ensino, contrária à perspectiva em que a avaliação surge como importante ferramenta para verificação das aprendizagens ou da qualidade do processo, abordaremos a avaliação dialética, novamente como movimento de análise e síntese, mas em relação à possibilidade de criar novos motivos e novas necessidades, que mobilizem os sujeitos a buscar novas ações e operações na busca por satisfazêlas.

* Primeira ação: o planejamento

Alicerçados às bases da teoria histórico-cultural, é importante destacarmos que o pressuposto que assumimos, ao tratar de "organização intencional" de atividades de ensino, parte da tese vigotskiana que continuamente temos indicado: "a pedagogia deve orientar-se não no ontem, mas no amanhã do desenvolvimento da criança" (VIGOTSKI, 2001, p. 333). 
Desse modo, o planejamento do ensino cuja orientação se alinha aos indicadores de desempenho, como aqueles que são resultado dos diferentes tipos de avaliações comuns ao cotidiano escolar e habitualmente operacionalizadas a favor da pseudointencionalidade pedagógica, pouco contribui para as possibilidades de desenvolvimento do amanhã da criança, pois, de acordo com os princípios vigotskianos, revela apenas aquilo que já se encontra amadurecido pelo estudante, o que não corresponde ao estágio máximo do desenvolvimento, mas apenas ao seu ponto inicial (VIGOTSKI, 2001).

Além disso, muitas vezes, os resultados dessas avaliações mostram ao professor pseudoapropriações de conceitos isolados e desconexos, decorados pelo estudante em semelhança com a analogia das ervilhas feita por Vigotski (2001), que compara esse modo de apropriação a ervilhas espalhadas em um saco, em que não existe relação entre uma e outra.

Moura e Araujo (2018), ao apontarem, brevemente, alguns recursos utilizados por professores como subsídio para o planejamento pedagógico, além das avaliações, as quais também abordamos em outros momentos desta pesquisa, retomam dois importantes balizadores do planejamento do ensino escolarizado: o livro didático e as propostas curriculares dos governos.

Para tratarmos do papel do livro didático e sua orientação em relação ao planejamento do ensino, recorremos a Catanante (2013) que, ao discutir a expansão do ensino fundamental, de oito para nove anos, analisa as implicações desse material na obstaculização do desenvolvimento do pensamento teórico, destacando a simplificação dos conceitos que são apresentados ao estudante de modo isolado do movimento lógico e histórico de criação. Ao tratar dessa implicação, a autora apresenta alguns exemplos de exercícios sobre "formas geométricas" e destaca:

No exercício em questão, podemos observar que as formas são tratadas como estáticas, não demonstram o movimento de criação do círculo, quadrado, retângulo e triângulo a partir das formas da natureza, a fim de satisfazer uma necessidade humana. O ensino das formas deve compreender este impacto, de busca e transformação da natureza e do próprio homem. Na maneira como se apresenta o exercício, o que ele propõe é o reconhecimento visual das formas, isso não implica em compreender o conceito presente em cada uma delas. Ou seja, é como se reconhecer as formas, pelo seu nome, fosse 
suficiente para a criança se apropriar da linguagem geométrica. (CATANANTE, 2013, p. 93)

As considerações feitas por Catanante (2013) sobre os aspectos simplificadores do processo de elaboração e apropriação dos conceitos a partir de exercícios do livro didático, no caso, relacionados à geometria, assemelhamse ao que discutimos anteriormente, sobre os princípios didáticos da escola tradicional, em que Davidov (2017) analisa os princípios do ensino, cuja essência fixa-se no caráter empírico-utilitarista e no pensamento empírico-classificador, uma vez que os conceitos são reduzidos a tarefas de reconhecimento visual, correspondência, associação e classificação, que, apesar de importantes para realização de atividades do cotidiano, não possibilitam o desenvolvimento multilateral que favorece a passagem do pensamento empírico para 0 pensamento teórico.

Nessa relação, o ensino não propicia a construção daquilo que, fundamentalmente, constitui-se como necessário para o desenvolvimento: 0 surgimento do novo (VIGOTSKI, 2001).

Em relação ao planejamento pautado pelos pressupostos advindos das propostas curriculares dos governos, recorremos a Freitas (2016, p. 129), que, ao discutir o processo de implementação da BNCC, aponta para o fato de que a construção de uma base comum curricular, ligada às políticas de responsabilização, cujas avaliações externas configuram-se como ferramentas de sistemático controle das práticas escolares e acabam por expropriar "a capacidade organizativa da escola e do magistério em relação ao seu trabalho pedagógico", limitam e equalizam os objetivos do ensino aos ideais dos reformadores educacionais.

Nesse sentido, o autor afirma que, se antes já se buscava o "controle" das práticas e das condutas, com a implementação de uma base, intensifica-se 0 domínio daquilo que deve ser ensinado pela escola como um todo, uma vez que, em nome da garantia do "direito de aprender das crianças", os reformadores da educação atribuem a si o direito de uniformizar a educação, padronizando "o que ensinar, quando ensinar e como ensinar nas escolas brasileiras" (FREITAS, 2016, p. 129).

Diante desses apontamentos, ao tratarmos da organização intencional do ensino, a intencionalidade à qual nos referimos sobrepuja o encabeçamento 
daquilo que está posto como "pronto e acabado", seja pelos resultados das avaliações, pelos direcionamentos dados pelos livros didáticos ou pelas orientações advindas das propostas curriculares dos governos. Em outras palavras, a intencionalidade pedagógica a que nos referimos deve buscar romper com o limiar que ignora o processo humano de elaboração dos conceitos, assim como o encapsulamento que limita a realização da atividade de ensino.

Nesse sentido, a intencionalidade da atividade pedagógica é mediada pela Avaliação Dialética, ao passo que, ao organizar seu trabalho, em primeiro momento, o professor se coloca em atividade na busca por compreender o que, em dado momento, mobilizou a humanidade na construção dos conceitos como resposta às suas necessidades. Esse momento corresponde ao que Moraes (2008) apresenta em relação aos elementos estruturantes da atividade, em que a premissa se relaciona à necessidade do professor de superar a atual prática de ensino.

Tal superação, que também deve ser apropriada pelos estudantes, configura-se para o professor, nesse momento de planejamento, como a idealização daquilo que se pretende alcançar, definindo os procedimentos teórico-metodológicos e as operações que, como recursos metodológicos, auxiliem-no na realização e no desfecho das situações de ensino (MORAES, 2008).

Diante disto, consideramos que a Avaliação Dialética, fundamentada pelos princípios vigotskianos, ao longo do planejamento do ensino, coloca os sujeitos em tal movimento que, na atividade pedagógica, não são apenas eles que sofrem alterações, mas, sobretudo, mudam as relações desses sujeitos com o outro e com o meio, novamente, transformando-os à medida que o transformam.

\section{* Segunda ação: a realização}

Após tratarmos dos aspectos que indicam a Avaliação Dialética como elemento mediador ao longo do planejamento realizado pelo professor em sua atividade de ensino, nosso movimento de estudo nos direciona à análise da realização das situações que, de antemão, foram idealizadas durante 0 planejamento. 
Nessa direção, para compreendermos em que medida a Avaliação Dialética também se configura como mediadora dos processos que ocorrem ao longo da realização das situações desencadeadoras de aprendizagem, faz-se necessário destacar que, entre professor e estudante, o ensino e a aprendizagem se objetivam na apropriação dos conceitos pelo desenvolvimento do pensamento teórico. Assim partimos da tese vigotskiana que afirma que todo conceito é uma generalização que se constitui na correlação entre os nexos próprios e outros nexos do sistema (VIGOTSKI, 2001).

Desse modo que buscamos defender a mediação da Avaliação Dialética ao longo processo de realização das situações desencadeadoras de aprendizagem, é necessário recorrer ao exemplo apresentado por Vigotski (2001) sobre a relação dos conceitos entre si, com os objetos e com outros conceitos, em que o autor destaca a ausência ou existência de um sistema, como ponto central da passagem do conceito empírico para o científico.

Neste exemplo, o autor trata da relação entre a criança e a palavra "flor", explicando que, para aquela que desconhece o significado das palavras lírio, violeta e rosa, esta relação se dará de modo muito diferente daquela que tem apropriados para si os significados de cada palavra, ou seja, "fora do sistema, os conceitos mantêm com o objeto uma relação diferente daquela que mantêm ao ingressarem em um determinado sistema" (VIGOTSKI, 2001, p. 379).

Em síntese, podemos dizer que a relação de sentido que a palavra "flor" apresenta no caso da criança que não compreende os significados das outras palavras, corresponde somente ao acréscimo de uma nova palavra ao seu vocabulário, e não a uma generalização. Todavia, se a criança conhece o significado das palavras lírio, violeta e rosa, certamente a relação que ela será capaz de estabelecer entre estas palavras e palavra flor dará nova qualidade ao seu pensamento, pois, ao estabelecer diferentes nexos, as possibilidades de desenvolvimento das funções psicológicas ampliam-se, proporcionando aos sujeitos condições não apenas para lidar com específicas situações, mas, sobretudo, para estabelecer inúmeras e infinitas possibilidades de equivalência entre os conceitos (VIGOTSKI, 2001).

Porque os conceitos não surgem na mente da criança como ervilhas espalhadas em um saco. Eles não se situam um ao lado do outro ou sobre o outro, fora de qualquer vínculo e sem quaisquer relações. De 
outro modo seria impossível qualquer operação intelectual que exigisse a correlação dos conceitos, seria impossível uma visão de mundo da criança, em suma, seria impossível toda a vida complexa do seu pensamento.

[...]

Graças a existência medida de generalidade, para cada conceito surge a sua relação com todos os demais conceitos, a possibilidade de transição de uns conceitos a outros, o estabelecimento de relações entre eles por vias inúmeras e infinitamente diversas. (VIGOTSKI, 2001, p. 359-366)

Avaliação Dialética, compreendida como unidade mediadora entre o ensinar e o aprender, na objetivação das situações desencadeadoras de aprendizagem, subsidia o professor na constante regulação de ações e operações que, idealmente, foram planejadas para que a apropriação dos conceitos possibilite, assim como escreve Vigotski (2001), estabelecer diversas e infinitas relações entre um conceito e outro.

Nesse sentido, avaliar dialeticamente permite superar o "isolamento" da estruturação dos conteúdos organizados nos livros didáticos (CATANANTE, 2013) e nas propostas curriculares dos governos (FREITAS, 2016), rompendo com aquelas "propostas de ensino que consideram o conhecimento como feito e acabado, nas quais para aprender o conceito pronto significa repeti-lo inúmeras vezes, por meio de exercícios estéreis" (ARAUJO, 2003, p. 54).

No ensino da Matemática, por exemplo, para os estudantes dos anos iniciais do ensino fundamental, comumente se apresenta como conceito de "unidade" a representação entre o valor absoluto dos signos numéricos 1, 2, 3, $4,5,6,7,8$ e 9 e a quantidade à qual cada um deles corresponde. Nesse sentido, para que a criança se aproprie do conceito de "unidade", habitualmente the é proposto que estabeleça a correspondência entre uma quantidade de desenhos e o signo que o representa, de modo que, nessa relação, acredita-se que, ao levar a criança a quantificar, consequentemente, o exercício Ihe proporcionará condições para que se aproprie do conceito de unidade presente no sistema de numeração decimal.

Araujo (2003) faz a discussão de um exemplo de exercício semelhante a este, em que, ao se solicitar ao estudante que estabeleça a correspondência entre a quantidade de florzinhas, patinhos, sorvetes etc., com o numeral indoarábico, aponta-se para a presença do desprezo sobre o processo sociocultural 
que, em dado momento da humanidade, levou homens e mulheres a buscar e elaborar soluções diante de necessidades objetivas de controle de quantidades.

Contrariamente a essa perspectiva, defendemos que o ensino dos conceitos construídos pela humanidade deve possibilitar a generalização que compreende que "uma unidade" corresponde não apenas ao valor absolutos dos símbolos numéricos de 1 a 9, mas também ao que se pode expressar pelos resultados das operações: 1.000 menos 999, 80 menos 79, 10 menos 9 "ou, em geral, a diferença entre dois números consecutivos, ou como qualquer número dividido por ele próprio, e ainda por meio de inúmeras outras formas" (VIGOTSKI, 2001, p. 366).

Assim, compreendemos que o ensino que possibilita aos sujeitos a passagem de um conceito a outro faz surgir relações cada vez mais complexas, tornando possível ao pensamento a passagem para novos e superiores vínculos que, antes, eram impossíveis de formar-se entre as ervilhas (VIGOTSKI, 2001).

Para tratarmos ainda mais detalhadamente desta relação, recorremos ao exemplo que Vigotski (2001) apresenta diante da tomada de consciência do estudante sobre os aspectos do sistema decimal. Ele aponta que inicialmente a criança aprende a atuar no campo do sistema decimal, antes de tomar consciência sobre ele, o que, para nós, corresponde ao amanhã do desenvolvimento da criança.

Nesse sentido, o ensino que permite ao escolar atuar sobre aquilo de que não tem consciência está organizado pelo que o estudante ainda não sabe, mas que se encontra em sua zona de desenvolvimento proximal. A Avaliação Dialética, nesse sentido, possibilita ao professor meios para que ele organize sua atividade de ensino, buscando situações desencadeadoras de aprendizagem que possam possibilitar, ao sujeito em atividade de aprendizagem, a tomada de consciência sobre o conceito que, neste caso, se refere aos nexos presentes no sistema decimal, como o controle de quantidades, o conceito de unidade, entre outros. Tal tomada de consciência, nas palavras de Vigotski (2001, p. 373), reside

na possibilidade de passagem para qualquer outro sistema, pois isto significa generalização do sistema decimal, formação de um conceito geral sobre os sistemas de cálculo. Por isso a passagem para qualquer sistema é um indicador direto da generalização do sistema decimal. A criança traduz do sistema decimal para um sistema baseado no 
número cinco, de modo diferente antes da fórmula geral e depois da fórmula geral.

Desse modo, assim como o autor afirma, compreendemos que, se a tomada de consciência do sistema decimal pelo escolar o instrumentaliza psicologicamente para atuar sobre um sistema baseado no número cinco, e essa generalização também lhe permite atuar sobre outros sistemas, então, a compreensão sobre as horas como produto da humanidade para controle do tempo, também não poderia ser compreendida como um sistema, cuja base de cálculo corresponde ao sessenta.

Fora dessa compreensão, encontramos o conceito de "hora" do mesmo modo como Araujo (2003, p. 54) qualifica o conceito de "correspondência um a um", revelado pelos exercícios de associação entre a quantidade de florzinha e o número indo-arábico: o conceito dado como "feito e acabado" que, por sua vez, desconsidera a dimensão lógica e histórica inerente a sua formação conceitual.

É comum ainda que, fora dessa compreensão, na busca por fazer com que os estudantes se apropriem do conceito, os professores lancem mão de listas de exercícios, inúmeras situações-problema, entre outros tipos de tarefas que, com objetivo de fazê-los "operar com as horas", possibilitem apenas a manipulação inconsciente que, em resposta a uma necessidade imediata, lida somente com a leitura e o registro de medidas de intervalo de tempo.

Essa forma de tratar dos modos de apropriação do conceito equivale à concepção apresentada por Vigotski (2001) sobre as ervilhas espalhadas em um saco, como se, isoladamente, não houvesse correlação entre os nexos dentro de um sistema de conceitos.

Nesse sentido, a Avaliação Dialética, como elemento intrínseco que permeia as ações que compõem a atividade de ensino, constitui-se na constante análise e síntese que regula, além do planejamento, a realização do trabalho do professor, para que, ao proporcionar situações desencadeadoras, não incorra no equívoco de tratar dos conceitos de modo isolado do movimento humano de criação e do sistema do qual faz parte, mas que sua intencionalidade vá ao encontro do ensino que possibilita condições para que os sujeitos participantes se apropriem dos conceitos, construindo generalizações que thes permitam avançar em direção ao nível de desenvolvimento potencial. 
Assim como destacamos anteriormente, as ações dos sujeitos, compreendidas sob a perspectiva da Teoria da Atividade, não apontam diretamente para o motivo da atividade em si (LEONTIEV, 2004), mas, como nos mostram Moura, Sforni e Lopes (2017), configuram-se como indispensáveis para sua satisfação.

Nesta lógica, ao tratarmos das duas primeiras ações, o planejamento e a realização da atividade do professor, destacamos a necessidade de se ultrapassar o ensino que ora está alicerçado aos resultados das avaliações, ora é organizado pelas indicações de conteúdos estruturados pelos livros didáticos, ou ainda, pelo ensino orientado por propostas curriculares dos governos, cuja lógica, assim como apontam Freitas $(2014,2016)$ e Moraes (2008), corresponde à conservação das características mercadológicas da educação.

Nesse sentido, a Avaliação Dialética, tomada como elemento mediador de todo o processo que compõe a relação ensino-aprendizagem, realizada pela atividade de ensino e de aprendizagem, em seu desfecho, qualifica-se como uma ação reguladora entre as operações idealizadas, realizadas e objetivadas na satisfação das necessidades dos sujeitos.

Essas ações, inicialmente mobilizadas por necessidades individuais (internas), passam a responder a uma necessidade precedente, que é externa, social e coletiva, e se realiza na concretização da apropriação do conhecimento pelas gerações (MOURA; ARAUJO, 2018).

O exemplo anteriormente discutido sobre a caçada coletiva destaca esta relação, e compreendemos que a necessidade de cada sujeito é satisfeita, ao passo que a necessidade coletiva de abater o animal realiza-se e permite que os envolvidos possam saciar suas necessidades de fome ou o frio.

No ensino, tal relação pode ser associada às situações desencadeadoras de aprendizagem que, apresentadas por Moura et al. (2010) como operações, criam condições para que os estudantes entrem em atividade. Um exemplo é a história virtual do conceito, do qual o professor lança mão, por possuir "em si um problema mobilizador oriundo de necessidades de ordem prática que gerou 0 desenvolvimento de um determinado conceito" (PIOTTO, 2020, p.337), na 
tentativa de proporcionar ao estudante uma situação semelhante àquela vivenciada pela humanidade em dado momento histórico.

$\mathrm{Na}$ história virtual, o estudante vivencia momentos cuja tensão o mobiliza a buscar soluções para resolver os problemas que the são propostos pelo professor (PIOTTO, 2020). Todavia, para que isso aconteça, as ações que envolvem o planejar e o realizar devem ser compostas por diversas operações, para que, ao final, o professor possa avaliar se o caminho percorrido até ali, de fato, possibilitou a apropriação dos conceitos.

É importante destacarmos que tal avaliação não representa a aplicação de um exame ou teste para mensurar o grau da aprendizagem, mas aparece como uma ação mediadora. Nesse sentido, a Avaliação Dialética indicará se os objetivos, idealmente planejados pelo professor, se configuraram como propostas significativas para os estudantes, constituindo-se na transição do pensamento empírico ao pensamento teórico.

\footnotetext{
O professor, ao avaliar, terá condições de conhecer o processo de apropriação do conhecimento. Dessa maneira, poderá intervir com o intuito de garantir a formação dos conhecimentos teóricos e consequentemente, a formação do pensamento teórico. (MORAES; MOURA, 2009, p. 115)
}

Diante disto, consideramos que a Avaliação Dialética, fundamentada pelos princípios da teoria histórico-cultural, ao ser assumida como intrínseca à totalidade da atividade de ensino, sob a premissa que a tem como "ação", mesmo que ela não esteja direcionada diretamente para o motivo da necessidade, possibilitará ao professor condições objetivas de regulação de todo o conjunto de operações necessárias para apropriação do conhecimento.

Defendemos ainda que, neste processo de avaliação, a inclusão da palavra "dialética", assim como explicam Moraes e Moura (2009), se dá porque, ao possibilitar ao professor condições de intervir para que o estudante se aproprie dos conhecimentos, tal apropriação não ocorre apenas no outro, ou seja, no estudante, mas também no professor, que, ao longo do percurso, se apropria de todas as etapas do ensino, tomando consciência de seu papel para com a humanidade.

Razão pela qual, a seguir, apresentaremos uma possibilidade de continuação para a cena imaginada no texto anterior, que, em resposta à 
pergunta: "Tia, o que vamos fazer hoje?", no lugar de um conceito "feito e acabado" (ARAUJO, 2003), estudantes dos anos iniciais do E.F., em uma escola da rede estadual, foram convidados a buscar soluções para um problema que, "guardadas as proporções, a humanidade já tenha se deparado em seu processo histórico" (PIOTTO, 2020), mas, ao retomá-lo, professor e estudantes puderam participar da construção de sentidos próprios a partir daqueles cujo significado social lhes foi apresentado por meio da organização intencional de uma atividade de ensino.

\subsection{Os trabalhos de Hércules}

Ao longo da pesquisa, analisamos princípios que, alicerçados às bases da teoria histórico-cultural, consideramos fundamentais para tomada de consciência sobre os processos que compõem a relação ensino-aprendizagem, destacando a Avaliação Dialética como elemento intrínseco e mediador do movimento entre o ensinar e o aprender (MORAES, 2008).

Nesse sentido, ao voltarmos nosso olhar para Atividade Orientadora de Ensino, nos concentramos em analisar a atividade do professor, considerandoa em três principais ações: o planejamento, a realização e o desfecho, e buscamos discutir em que medida a Avaliação Dialética, como processo de análise e síntese da atividade de ensino, pode configurar-se como mediadora da relação ensino-aprendizagem, pois regula ações e operações para que a função da educação seja objetivada por meio das condições de apropriação do conhecimento.

Há de se ressaltar que a perspectiva que assumimos sobre conhecimento parte do princípio defendido por Moura e Araujo (2018): ele é considerado como um bem inalienável, resultado das relações vivenciadas entre os sujeitos para a produção da vida, uma vez que a incessante luta por aperfeiçoar tudo aquilo que pudesse contribuir para a satisfação das necessidades humanas levou os sujeitos a produzirem ferramentas simbólicas que permitiram que outros pudessem se apropriar de determinada experiência, sem dela terem participado concretamente.

Desse modo, ao tratarmos do planejamento, da realização e do desfecho como principais ações da atividade docente, não nos referimos apenas ao início, 
meio e fim de uma sequência didática, mas a um projeto educativo que, em sua totalidade, fundamenta e potencializa a atividade de ensino, cujo objetivo se centra na necessidade de possibilitar que as ferramentas simbólicas, fruto da experiência humana, sejam apropriadas por todos os sujeitos.

Nesse movimento, a resposta à pergunta: “Tia, o que vamos fazer hoje?” estará subordinada à formação da consciência do professor em relação aos orientadores de sua prática, sejam estes os princípios teóricos-metodológicos que norteiam o modo como ele compreende a relação entre os sujeitos envolvidos no processo de ensino e aprendizagem, seja a concepção que assume diante da relação entre aprendizagem e desenvolvimento.

Nesse contexto, há ainda que se considerar a influência da "normalização" de condutas que, incorporadas à cultura escolar via formação docente, determinam o surgimento do que definimos por "pseudointencionalidade pedagógica" que, uma vez associada à operacionalização dos diversos instrumentos avaliativos (FREITAS, 2002), liga-se a um modelo de ensino que responde à implementação de políticas de responsabilização, cujo eixo se encontra na vinculação entre a melhoria da educação e a liberação de recursos diante do cumprimento de metas (FREITAS, 2016), sob a premissa do direito educativo que forme o cidadão e o qualifique para o trabalho.

Podemos destacar também a influência dos conteúdos padronizados presentes nos livros didáticos e nas propostas curriculares dos governos que, de acordo com Freitas (2016), estimam pelo controle que se estende desde o conteúdo a ser ensinado até os métodos que se utilizam em sala de aula, desencadeando, sobretudo, a conservação do ensino, em que a apropriação do conceito se alinha ao caráter externo e imediato, característico do pensamento empírico, no qual "a relação do homem com o conhecimento reduz-se a descrição dos objetos circunstanciais, em que a comparação constitui a via principal para a formação do conceito" (MORAES, 2008, p. 52).

Diante disso, ao longo deste trabalho, ao analisarmos a relação entre a influência de cada um dos elementos discutidos sobre os processos que compõem a relação ensino-aprendizagem, compreendemos que a formação da consciência do professor em relação ao movimento de sua própria atividade, bem como sobre os modos com que suas práticas e condutas se realizam diante da atividade do estudante, se constitui por meio da Avaliação Dialética que, pelo 
movimento de análise e síntese de suas ações e operações, qualifica-se como elemento intrínseco, fundamental e estruturante entre o ensinar e o aprender.

Assim, compreendemos que a resposta do professor a uma pergunta como a do estudante, sobre o que fariam durante a aula, deve ser aquela que possibilite ao sujeito em aprendizagem condições para que se aproprie das ferramentas simbólicas construídas pela experiência humana, de modo que estas sejam significadas por sua própria experiência, superando o ensino voltado ao desenvolvimento de habilidades essenciais para lidar apenas com conhecimentos do meio circundante.

Para discutirmos este ponto, vamos imaginar um desfecho para situação anteriormente apresentada:

[...] Ao passar pelo portão de entrada, corre para quadra, onde muitos brincam com bola e espera o sinal. Vai para fila, caminha até a classe, organiza-se na carteira e aguarda ansiosamente o momento em que a aula irá começar... Sem conseguir esperar, pergunta: "Tia, o que vamos fazer hoje?". Nesse momento, a professora vira-se em direção à criança que, com olhar atento e curioso, aguarda ansiosamente sua resposta, diz: "Hoje teremos um grande problema para resolver... Vocês conhecem o semideus chamado Hércules? Conta a lenda ${ }^{13}$ que Hércules, filho de Zeus e Hera, assombrava a todos: comia por vinte homens, arrancava árvores só por brincadeira e lutava vitoriosamente contra touros e leões. Quiron, o centauro, ensinava-Ihe a arte da caça, do manejo do arco e de lanças. Lino, o velho filósofo, ensinava-o sobre poesia e música. Mas, quanto mais Quiron se orgulhava de seu aluno, mais Lino, o fraco e apático, fazia-lhes mil censuras. Até que um dia, o rapaz, que era de temperamento impulsivo, sentiu o sangue ferver Ihe nas veias diante de tantas repreensões. Apanhou uma pedra e deu com ela na cabeça do velho filósofo. Sob o tremendo golpe, Lino tombou ao chão. Estava morto. Hércules, ao perceber o que havia feito naquele momento de fúria, sentiu grande arrependimento e mágoa. Ele não podia suportar. Arrependido, se apresentou diante do mestre dos mestres, perguntando-Ihe o que poderia fazer para corrigir seu erro e devolver a vida a Lino, o velho filósofo. "Só há uma maneira de reparar o mal que fez". Disse o sábio mestre, após consultar o oráculo. E continuou: "De tudo que tem, só lhe

\footnotetext{
${ }^{13}$ História Virtual elaborada pela autora desta pesquisa. Adaptação da lenda grega "Os doze
} trabalhos de Hércules", para ensino do conceito de controle e medidas de tempo. 
restará a força e, sem qualquer conhecimento, você deverá cumprir todos os trabalhos que the darei. Estes serão os mais difíceis de toda humanidade, mas se conseguir concluí-los, além de receber seus conhecimentos de volta, o mal que fez será reparado e Lino receberá novamente sua vida". Como era grande sua vontade de reparar o mal que havia feito, rapidamente, o rapaz aceitou a proposta do mestre e, no mesmo instante, todos os seus conhecimentos foram retirados e guardados sob sete chaves. Então o mestre the apresentou seu primeiro trabalho: "Você deverá capturar as éguas antropófagas que fugiram na noite de ontem e devolvê-las a Diomedes até o meio-dia do próximo amanhecer". As éguas eram os animais selvagens mais ferozes de todos os tempos. Matavam os que cruzassem seus caminhos, eram perversas e não tinham piedade. $O$ rapaz precisava capturar uma a uma rapidamente, para que fosse cessada toda a atrocidade que causavam por onde passavam. Capturá-las não seria tão difícil, pois Hércules contava com sua força; seu grande desafio era como realizar essa tarefa, se, ao perder todos os seus conhecimentos, havia perdido também sua noção sobre o tempo! Como Hércules poderá concluir seu primeiro trabalho no tempo previsto pelo sábio? Como podemos ajudá-lo?

A história virtual apresentada surge como exemplo concretizado de uma das operações idealizadas ao longo do planejamento realizado pelo professor, com objetivo de engajar nos estudantes certa "tensão criativa" (LANNER DE MOURA, 2002) que, aproximando-os da que foi vivenciada pela humanidade no processo de elaboração do conceito, permite - assim como permitiu a esta pesquisadora -, a construção de vivências em que a necessidade social de controle da passagem do tempo pode ser mobilizada nos estudantes pelo sentido pessoal atribuído por cada um à difícil tarefa que se objetivava em modos de ajudar o semideus a concluir seu trabalho, (re)criando meios para controlar tempo.

Nesse movimento de apropriar-se do conceito de que o controle do tempo se refere a uma contínua sucessão de quantidades (CROSBY, 1999), a possibilidade de construção de outras generalizações, como aquelas que se referem à relação entre os movimentos da Terra e os conceitos de dia, mês, ano, estações, assim como o estabelecimento dos diferentes fusos horários, tem sua significação como cultura humana e, por isso, é parte constituinte do objeto de estudo em questão. 
Dessa forma, possibilitar condições para que os sujeitos se apropriem dos conceitos em sua totalidade, e não apenas de fragmentos revela-se na atividade de ensino que faz com que a criança se coloque acima de si mesma, exigindo mais do que aquilo que ela pode dar hoje (VIGOTSKI, 2001), ou seja, mais do que aquilo que ela tem apropriado pela experiência empírica; entretanto, não mais do que aquilo que ela é capaz de fazer em parceria, pois "ensinar uma criança o que ela não é capaz de aprender é tão estéril quanto ensiná-la a fazer o que ela já faz sozinha" (VIGOTSKI, 2001, p. 336 - 337).

Nessa medida, a atividade de ensino, intencionalmente planejada, apresenta-se como possibilidade para que as riquezas deste mundo, como bens de gerações precedentes, possam ser apropriadas por outros sujeitos que, participando em conjunto da produção de diversas formas da atividade social, permitem que cada indivíduo aprenda a ser humano, pois somente o que a natureza lhes oferece ao nascer não basta para vivermos em sociedade. É preciso adquirir o que foi alcançado no decurso do desenvolvimento histórico da sociedade humana, para que o sujeito possa humanizar-se (LEONTIEV, 2004). 


\section{CONSIDERAÇÕES FINAIS}

Ao longo do nosso processo de estudo e elaboração desta pesquisa, para análise da avaliação do ensino, significada pelos preceitos da teoria históricocultural e objetivada por meio da atividade docente e alicerçada nos princípios teórico-metodológicos da Atividade Orientadora de Ensino (AOE), buscamos compreender e significar alguns dos elementos que considerávamos fundamentais para objetivar a avaliação como mediadora das possibilidades de desenvolvimento humano.

Nesse movimento, elencá-los e significá-los com base nos preceitos teóricos orientadores desta pesquisa configurou-se como uma árdua tarefa, pois, à medida que cada um deles era compreendido, desencadeava a "desconstrução" da experiência construída por esta pesquisadora, e o que antes era tido como essencial para o desenvolvimento dos estudantes clarificou-se como essencial apenas para a preservação de habilidades laborais que passamos a compreender como obstaculizadoras do real desenvolvimento do pensamento teórico (DAVIDOV, 2017).

Entretanto, mesmo diante do fato de termos considerado esta tarefa como "um trabalho de Hércules", podemos afirmar que, embora todas as dificuldades, ela nos permitiu vivenciar aquilo que pretendíamos defender no início desta pesquisa: a avaliação como o intrínseco movimento de análise e síntese de ações e operações que, intencionalmente planejadas, contribuem para que os sujeitos possam se apropriar das riquezas construídas pelas gerações precedentes, com vistas ao desenvolvimento humano (ARAUJO, 2003; MORAES, 2008, MOURA et al. 2010, MOURA; ARAUJO, 2018; MOURA; SFORNI; LOPES, 2017; PIOTTO, 2020).

Movidos por esse objeto, entendemos que, na construção de uma pesquisa cujo centro se objetivava na significação da avaliação, analisar as relações entre os sujeitos que a vivenciam nos espaços escolares caracterizavase como indispensável para compreendermos os papéis sociais ocupados pela criança e pelo adulto na relação professor-estudante, bem como o lugar da avaliação diante dessa relação.

Em primeiro lugar, isso nos levou a compreender que as concepções que sustentam a relação professor-estudante nos processos de ensino e 
aprendizagem equivocam-se diante da comum associação entre "a construção da aprendizagem" e as concepções teóricas, comuns à nova pedagogia e contrárias ao ensino tradicional, no qual o estudante é considerado como indivíduo no centro da atividade educativa, e ao professor cabe "mediar" a relação entre a criança e o conhecimento. Nesse sentido, buscamos trazer à luz a defesa de que, na atividade educativa, a atividade do professor, mediada pela avaliação dialética, constitui-se como aquela que, ao articular os objetos da atividade de ensino, possibilita, a si e ao outro, condições de apropriação dos bens culturais construídos historicamente.

Diante disso, não estamos tentando substituir a fórmula que diz que estudante é tudo e professor é nada, pela inversa, em que o professor é tudo e o estudante é nada, mas pretendemos destacar que, na relação professorestudante, partimos da tese vigotskiana que afirma que o professor é aquele que tem "a capacidade de exercer uma influência educativa direta [...] [e por isso] reconhecemos que sua importância é incomensuravelmente maior" (VIGOTSKI, 2003, p. 76).

Piotto (2020), ao tratar dos preceitos da Atividade Orientadora de Ensino, reafirma a tese que temos defendido, pois destaca que a atividade do professor deve ser considerada como aquela que, com a intenção de possibilitar a apropriação dos instrumentos psicológicos que, construídos pelas gerações precedentes, são capazes de possibilitar o desenvolvimento, organizar situações desencadeadoras de aprendizagem, que mobilizam no estudante necessidades para que se coloque em atividade de aprendizagem, assim como descrevem Moura et al. (2010, p. 216, grifo nosso):

\footnotetext{
Para que a aprendizagem se concretize para os estudantes e se constitua efetivamente como atividade, a atuação do professor é fundamental ao mediar a relação dos estudantes com o objeto do conhecimento, orientando e organizando o ensino. As ações do professor na organização do ensino devem criar, no estudante, a necessidade do conceito, fazendo coincidir os motivos da atividade com o objeto de estudo. O professor, como aquele que concretiza os objetivos sociais objetivados no currículo escolar, organiza o ensino: define ações, elege instrumentos e avalia o processo de ensino e aprendizagem.
}

Desse modo, consideramos que a atuação do professor se configura como aquela que, em processo de análise e síntese, ao avaliar o processo de 
ensino e aprendizagem, direciona-se pela totalidade da relação ensinoaprendizagem, em que a avaliação como ação-instrumento, revela-se, não como produto, mas como forma e conteúdo do seu trabalho. Nesse sentido, o conceito de Zona de Desenvolvimento Proximal (VIGOTSKI, 2001, 2007) como "espaço otimizador" das possibilidades de desenvolvimento, liga-se à concepção de uma avaliação que se oriente pelo amanhã do estudante, ou seja, que leve em conta que a aprendizagem deve fazer a criança avançar, passando daquilo que sabe para aquilo que ainda não sabe, mas que virá a saber no decurso de sua aprendizagem (VIGOTSKI, 2010).

Em segundo lugar, para aprofundarmos nossa compreensão sobre a avaliação como elemento intrínseco à totalidade da atividade educativa, colocamo-nos a discutir a influência dos princípios presentes nas propostas curriculares dos governos para educação brasileira a partir da Constituição de 1988, destacando as implicações da "normalização" de concepções voltadas à conservação dos ideais capitalistas (MORAES, 2008), como o alcance de metas, a introdução de políticas de responsabilização e modos de controle que, sob a temática das competências, foram inseridos na cultura escolar e legitimados pelos sujeitos que ocupam os espaços educativos em um movimento acrítico, via formação de professores (FREITAS, 2002).

Ao iniciarmos essa etapa da pesquisa, buscamos destacar as limitações desse modelo que, revestido pelo slogan do chamado "direito de aprendizagem", tem inserido modos de controle, não apenas no que diz respeito ao currículo, mas, sobretudo, às práticas de ensino presentes nas escolas (FREITAS, 2016), uma vez que relaciona o uso de instrumentos avaliativos à operacionalização a favor de uma verificação que unicamente aponta para o desempenho dos estudantes e ao alinhamento do ensino às propostas indicadas pelos documentos referenciais, como a BNCC, por exemplo.

Assim como destacamos anteriormente, autores como Freitas (2014, 2016, 2017) Ravitch (2010), Sousa (2014) e outros, discutem as implicações desse modelo que aponta para o incentivo ao ensino voltado apenas para a resolução de testes, ou ainda, para a incessante busca e adoção de estratégias que, em sua maioria, visam somente ao alcance de metas e não necessariamente correspondem a mudanças na qualidade da relação ensinoaprendizagem; e alinha-se ao que temos defendido sobre esse molde que 
conserva as características de uma atividade pedagógica que, em sua gênese, replica práticas e "a sua função primordial não consiste na formação humana dos sujeitos, mas garantir a preparação de homens e mulheres para fins mercadológicos" (MORAES, 2008, p. 43).

Diante disso, colocamo-nos a analisar em que medida a relação de controle advinda dos referenciais poderia orientar as práticas e as condutas dos sujeitos no cenário educativo.

Para análise do nosso objeto, inicialmente não constava em nosso projeto tratar das habilidades de ensino previstas pela BNCC como essenciais para o desenvolvimento pleno do cidadão. Entretanto, ao longo dessa etapa da pesquisa, isto fez-se necessário para diferenciarmos as ações e as operações que, presentes na organização de situações de ensino, poderiam ser qualificadas como "desencadeadoras de aprendizagem", dirigindo os sujeitos ao desenvolvimento dos nexos próprios do pensamento teórico (DAVIDOV, 2017), ou reprodutoras de modelos, cujo desenvolvimento de tarefas escolares aponta somente, para a conservação dos nexos presentes no cotidiano.

Nesse sentido, a escolha da análise de habilidades voltadas ao ensino das horas não se deu ao acaso, mas em resposta à necessidade desta pesquisadora, motivada pela obrigatoriedade de aplicar, em sala de aula, uma sequência didática ${ }^{14}$ cujo eixo se norteava pelo desenvolvimento de habilidades voltadas ao ensino da leitura e do registro de horas.

E, como a aplicação de toda sequência didática comumente sugere uma proposta de avaliação das aprendizagens, passamos a discutir a relação entre as dimensões instrumentais e operacionais presentes nesta concepção, cujo molde se alinha ao fechamento do processo ou à verificação da qualidade do processo ocorrido (FREITAS, 2014), desencadeando para o decurso dessa pesquisa a compreensão sobre 0 que denominamos por "pseudointencionalidade pedagógica", diante da naturalidade da inserção de instrumentos avaliativos operacionalizados para verificação de pseudoapropriações pelos estudantes.

Tal discussão nos levou a significar a avaliação com base na perspectiva dialética presente na teoria histórico-cultural. E, ao afirmá-la como instrumento

\footnotetext{
${ }^{14}$ Sequência Didática compilada no anexo 5 dessa pesquisa.
} 
psicológico que, construído na relação entre os sujeitos, constitui-se como intrínseco à atividade humana e, por isso, intrínseco à atividade docente (MORAES, 2008), passamos a defendê-la como Avaliação Dialética.

A escolha de um nome surgiu pela necessidade de que, ao passo que a defendíamos como unidade "mediadora" das possibilidades de desenvolvimento humano, pudéssemos diferenciá-la da "avaliação mediadora" descrita por Hoffmann (1992), cuja concepção parte da construção de um ensino em que os erros dos estudantes são vistos como possibilidades de intervenções no processo de aprendizagem.

A diferença, aqui, não está na aplicação de uma avaliação para medir os conhecimentos e, com base neles, planejar futuras intervenções, mas em compreender que, como inerente, ela medeia a organização do ensino, para que, de modo intencional, os sujeitos - professor e estudante - venham a se apropriar do conhecimento produzido (MOURA; ARAUJO, 2018; MOURA; SFORNI; LOPES, 2017; PIOTTO, 2020).

Diante disso, passamos a buscar meios para estabelecer e significar a relação entre a Avaliação Dialética e os princípios teórico-metodológicos da Atividade Orientadora de Ensino, o que, para nós, se apresentou como um novo desafio.

Para isso, a decisão de contar uma história, partindo de uma cena, possibilitou que nos atentássemos à atividade realizada pelo professor e, separando-a em três principais ações, buscamos destacar a presença da Avaliação Dialética ao longo do planejamento, da realização e do desfecho de uma atividade pedagógica. E, apesar de termos apresentado cada uma delas separadamente, defendemos, sobretudo, que são interdependentes entre si.

Separá-las foi a estratégia que buscamos para apresentar a avaliação em sua plenitude e totalidade, pois, uma vez que ela se constitui no movimento de análise e síntese em cada uma dessas ações, entendemos que são desencadeadas no professor possibilidades para que ele regule 0 desenvolvimento daquelas operações que idealmente foram planejadas, para que os sujeitos em aprendizagem venham a se apropriar, pelo ensino escolarizado, dos conceitos culturalmente construídos pela humanidade.

Por fim, trouxemos a história virtual "Os trabalhos de Hércules", como possibilidade de conclusão desta pesquisa, e, sobretudo, com a intenção de 
traçar novos percursos no que se refere à superação do ensino que se orienta pelo desenvolvimento de habilidades comuns às tarefas do cotidiano.

Nesta pesquisa, ao assumirmos a avaliação como nosso objeto, além de buscarmos significá-la ao longo dos intrincados processos que envolvem a relação ensino-aprendizagem, pretendíamos também tratar da construção da consciência do professor sobre todas as etapas do ensino. A essa consciência, silenciada por aqueles que dirigem a educação, sob o pretexto de um lema que discursa a respeito de uma educação de qualidade, fazendo avançar a consolidação dos princípios capitalistas (MARSIGLIA, 2017), é que pretendemos dar voz, para que, fortificados, nós, professores, possamos compreender que o significado de avaliar não se refere ao direcionamento ou à orientação acerca dos resultados de uma pseudoapropriação de conhecimentos por parte dos estudantes, mas, sobretudo, "trata-se da avaliação como análise e síntese das atividades dos sujeitos, tanto daquele que ensina como daquele que aprende" (MORAES, 2008, p. 233).

Assim, ao avaliar a avaliação, não tratamos somente da inserção e da influência nos modos de organização do ensino, em decorrência da existência de instrumentos físicos, mas da construção de uma consciência, em que o ato avaliativo venha sobrepujar as dimensões instrumentais e operacionais, para configurar-se como ação intrínseca aos sujeitos e, por isso, mediadora das relações entre os homens e os objetos do conhecimento construídos pela humanidade. 


\section{REFERÊNCIAS}

AÇÃO EDUCATIVA. INSTITUTO PAULO MONTENEGRO. Relatório INAF 2018. Indicador de alfabetismo funcional. Disponível em: https://drive.google.com/file/d/1ez-6jrlrRRUm9JJ3MkwxEUffltjCTEI6/view Acesso em: 24 jun. 2020.

ALTMANN, H. Influências do Banco Mundial no projeto educacional brasileiro. Educação e Pesquisa, Rio de Janeiro, v. 28, n. 1, p. 77-89, 2002.

ANTES DA PANDEMIA, BRASIL TINHA 51,7 MILHÕES ABAIXO DA LINHA DA POBREZA, DIZ IBGE. Isto É. Dinheiro. Estadão Conteúdo. 12 nov 2020. Disponível em: https://www.istoedinheiro.com.br/antes-da-pandemia-brasiltinha-517-milhoes-abaixo-da-linha-da-pobreza-diz-ibge/ Acesso em: $14 \mathrm{dez}$. 2020.

ARAUJO, E. S. Da formação e do formar-se: a atividade de aprendizagem docente em uma escola pública. 2003. 186 f. Tese (Doutorado em Educação) Faculdade de Educação, Universidade de São Paulo, São Paulo, 2003.

ARAUJO, E. S. Gênese e desenvolvimento da organização do ensino de matemática em um município paulista. Ribeirão Preto, SP, Brasil: Faculdade de Filosofia, Ciências e Letras de Ribeirão Preto (FFCLRP), Universidade de São Paulo, 2016. Processo 2016/ 07750-3.

ARAUJO, E. S.; MORAES, S. P. G. Dos princípios da pesquisa em educação como atividade. In: MOURA, M. O. de (org.). Educação escolar e pesquisa na teoria histórico-cultural. São Paulo: Loyola, 2017.

ASSIS, C. S. C. Relatório parcial apresentado à Fundação de Amparo à Pesquisa do Estado de São Paulo (Fapesp). Setembro 2019 - agosto 2020. In: ARAUJO, E. S. Gênese e desenvolvimento da organização do ensino de matemática em um município paulista. Ribeirão Preto, SP, Brasil: Faculdade de Filosofia, Ciências e Letras de Ribeirão Preto (FFCLRP), Universidade de São Paulo. Processo 2016/ 07750-3.

AZEVEDO, J. M. Avaliação das escolas: fundamentar modelos e operacionalizar processos. Lisboa: Conselho Nacional da Educação, 2005. Disponível em: https://www.cnedu.pt/content/antigo/files/pub/AvaliacaoEscolas/4-Estudo.pdf

BRASIL. Constituição (1988). Constituição da República Federativa do Brasil. Brasília, DF: Senado Federal: Centro Gráfico, 1988.

BRASIL. Ministério da Educação e do Desporto. Plano decenal de educação para todos - 1993-2003. Brasília, 1993.

BRASIL. Ministério da Educação. Parâmetros Curriculares Nacionais para o Ensino Fundamental. Brasília, MEC/SEF, 1997. 
BRASIL. Ministério da Educação. Secretaria de Educação Básica. Prova Brasil. Brasília: MEC, 2013a. Disponível em: http://portal.mec.gov.br/prova-brasil. Acesso em: 02 out. 2018.

BRASIL. Ministério da Educação. Secretaria de Educação Básica. Avaliação Nacional de Alfabetização. Brasília: MEC, 2013b. Disponível em: http://portal.mec.gov.br/ana. Acesso em: 02 out. 2018.

BRASIL. Ministério da Educação. Secretaria de Educação Básica. Diretrizes Curriculares Nacionais Gerais da Educação Básica. Brasília: MEC, 2013c. Disponível em: http://portal.mec.gov.br/index.php?option=com_docman\&view=download\&alias $=13448$-diretrizes-curiculares-nacionais-2013-pdf\&ltemid=30192. Acesso em: 02 set. 2018.

BRASIL. Lei 13.005, de 25 de junho de 2014. Aprova o Plano Nacional de Educação - PNE e dá outras providências. 2014. Disponível em: https://www.planalto.gov.br/ccivil_03/_ato2011-2014/2014/lei//13005.htm.

Acesso em: 25 jan. 2020.

BRASIL. Boletim SARESP. Disponível em: http://saresp.fde.sp.gov.br/2015/. Acesso em: 14 mar. 2016.

BRASIL. Ministério da Educação. Secretaria de Educação Básica. Base Nacional Comum Curricular. Brasília: MEC, 2017. Disponível em: http://basenacionalcomum.mec.gov.br/wp-content/uploads/2018/02/bncc20dez-site.pdf. Acesso em: 04 maio 2017.

BRASIL TEM 2.736 mortes por Covid em 24h e bate recorde de média móvel de óbitos e de casos. Folha de S. Paulo. Disponível em: https://www1.folha.uol.com.br/equilibrioesaude/2021/03/brasil-tem-2736mortes-por-covid-em-24-h-e-media-movel-de-obitos-ja-passa-de-2000-obitospor-dia.shtml. Publicado em: 17 mar. 2021. Acesso em: 18 mar. 2021.

BRITO, K. D. M. de. A constituição do coletivo e o processo de significação docente. Dissertação (Mestrado) - Faculdade de Filosofia, Ciências e Letras de Ribeirão Preto, Universidade de São Paulo, Ribeirão Preto, 2017.

BRITO, K. D. M. de; ARAUJO, E. S. A constituição do coletivo e o processo de significação docente. 2017. Universidade de São Paulo, Ribeirão Preto, 2017. Disponível em: < http://www.teses.usp.br/teses/disponiveis/59/59140/tde26052017-132846/ >

CARAÇA, B. de J. Conceitos fundamentais da Matemática. Lisboa: Gradiva, 2010.

CARDOSO, C.G.C.; PUENTES, R. V. V. V. DAVIDOV: contribuições à teoria da atividade de estudo. In: PUENTES, R. V.; LONGAREZI, A. M. (org) Enfoque histórico-cultural e aprendizagem desenvolvimental: contribuições na perspectiva do gepedi, Goiânia, Phillos Academy, 2021. 
CASTRO, M. H. G. de; TIEZZI, S. A reforma do ensino médio e a implantação do ENEM no Brasil. Desafios, Tocantins, v. 65, n. 11, p. 46-115, 2004.

CATANANTE, I. T. A organização do ensino de matemática no primeiro ano do ensino fundamental. 2013. Dissertação (Mestrado em Educação) Universidade de São Paulo, Ribeirão Preto, 2013.

CHARLOT, B. A mistificação pedagógica: realidades sociais e processos ideológicos na teoria da educação. Rio de Janeiro: Zahar, 1979.

CROSBY, A. W. A mensuração da realidade: a quantificação e a sociedade ocidental 1250-1600. São Paulo: Editora UNESP, 1999.

CURY, C. R. J. Direito à educação: direito à igualdade, direito à diferença. Cadernos de Pesquisa, São Paulo, n. 116, p. 245-262, 2002.

CURY, C. R. J. Por um novo plano nacional de educação. Cadernos de Pesquisa, São Paulo, v. 41, n. 144, p. 790-811, 2011.

DAVIDOV, V. V. La enseñanza escolar y el desarollo psíquico. Moscou: Progresso, 1988.

DAVIDOV, V. V. Análise dos princípios didáticos da escola tradicional e dos possíveis princípios do ensino em um futuro próximo. Ensino desenvolvimental: antologia, 2017. v. 1, p. 211-222.

DAVYDOV, V. V. What is real learning activity? In: HEDEGAARD, M.; LOMPSHER, J. (ed.). Learning activity and development. Aarhus: Aarhus University Press, 1999. (Exercício de tradução de responsabilidade de Maria Isabel Batista Serrão [Doutoranda, Área de Ensino de Ciências e Matemática, Programa de Pós-Graduação em Educação, Faculdade de Educação, USP, Membro do Grupo de Estudos e Pesquisa da Atividade Pedagógica GEPAP/USP] e Wellington Lima Cedro [Mestrando, Área de Ensino de Ciências e Matemática, Programa de Pós-Graduação em Educação, Faculdade de Educação, USP, Membro do Grupo de Estudos e Pesquisa da Atividade Pedagógica - GEPAP/USP]).

DECLARAÇÃO UNIVERSAL DOS DIREITOS HUMANOS. Disponível em https://www.ohchr.org/EN/UDHR/Pages/Language.aspx?LanglD=por Acesso em: 02 abr. 2020.

DUARTE, N. Educação escolar, teoria do cotidiano e a escola de Vigotski. In: DUARTE, N. Educação escolar, teoria do cotidiano e a escola de Vigotski. Campinas: Autores Associados, 2001. p. 115-115.

DUBET, F. A escola e a exclusão. Tradução de N. L. de REZENDE. Cadernos de pesquisa, n. 119, p. 29-45, São Paulo, 2003.

ESTEBAN, M. T. Avaliação no cotidiano escolar. In: ESTEBAN, M. T. (org.). Avaliação escolar: uma prática em busca de novos sentidos. Rio de Janeiro: DP \& A, 2002. 
FACCI, M. D. Teorias educacionais e teorias psicológicas: em busca de uma psicologia marxista da educação. In: DUARTE, N. (org.) Crítica ao fetichismo da individualidade. Campinas, SP: Autores Associados, 2004. p. 99-120.

FALCÃO, A.; MASSARANI, M. Mania de explicação. São Paulo: Moderna, 2001.

FERNANDES, R.; GREMAUD, A. P. Qualidade da educação: avaliação, indicadores e metas. Educação básica no Brasil: construindo o país do futuro. Rio de Janeiro: Elsevier, 2009. v. 1, p. 213-238.

FRANCO, P. L. J. O desenvolvimento de motivos formadores de sentido no contexto das atividades de ensino e estudo na escola pública brasileira. 2015. 359 f. Tese (Doutorado em Ciências Humanas) - Universidade Federal de Uberlândia, Uberlândia, 2015.2 Disponível em: https://doi.org/10.14393/ufu.te.2015.18

FREIRE, P. A pedagogia do oprimido. 17. ed. Rio de Janeiro: Paz e Terra, 1987.

FREIRE, P. Educação como prática da liberdade. 28. ed. Rio de Janeiro: Paz e Terra, 2005.

FREITAS, H. C. L. de. Formação de professores no Brasil: 10 anos de embate entre projetos de formação. Educação \& Sociedade, São Paulo, v. 23, n. 80, p. 136-167, 2002.

FREITAS, H. C. L. de. Políticas de responsabilização: entre a falta de evidência e a ética. Cadernos de Pesquisa, Rio de Janeiro, v. 43, n. 148, p. 348-365, 2013.

FREITAS, L. C. de. Avaliação: para além da "forma escola". Educação: Teoria e Prática, v. 20, n. 35, p. 89-89, 2010.

FREITAS, L. C. Os reformadores empresariais da educação e a disputa pelo controle do processo pedagógico na escola. Educação \& Sociedade, Campinas, v. 35, n. 129, p. 1085-1114, out./dez. 2014.

FREITAS, L. C. A importância da avaliação e seus desafios: em defesa de uma responsabilização participativa. Em Aberto, Brasília, v. 29, n. 96, 2016.

FREITAS, L. C. et al. Avaliação educacional: caminhando pela contramão. Petrópolis: Vozes, 2017.

HOFFMANN, J. M. Avaliação: mito \& desafio: uma perspectiva construtivista. In: HOFFMANN, J. M. Avaliação: mito \& desafio: uma perspectiva construtivista. Porto Alegre: Mediação, 1992.

KING, M. L. Discurso. Eu tenho um sonho: há 55 anos, Martin Luther King proferia discurso histórico. Brasil de fato. Disponível em: https://www.brasildefato.com.br/2018/08/28/eu-tenho-um-sonho-ha-55-anos- 
martin-luther-king-proferia-discurso-historico. Publicado em: 28 ago. 2018. Acesso em: 18 jun. 2021.

KRAEMER, M. E. P. A avaliação da aprendizagem como processo construtivo de um novo fazer. Avaliação, Campinas, v. 10, n. 2, 2005.

LACERDA, W. M. G. Famílias e filhos na construção de trajetórias escolares pouco prováveis: o caso dos iteanos. 2006, 416p. Tese (Doutorado em Educação) - Universidade Federal Fluminense (UFF), Niterói, 2006.

LANNER DE MOURA, A. R. O movimento conceitual no ensino de matemática. In: FÓRUM LUSO BRASILEIRO DE MATEMÁTICA NA INFÂNCIA, 1., 28 e 29 de junho de 2002. São José da Madeira, Portugal.

LEITE, D. M. O desenvolvimento da criança: leituras básicas. São Paulo: Companhia Editora Nacional - Editora da Universidade de São Paulo, 1972.

LEON, F. L. L. de; MENEZES-FILHO, N. A. Reprovação, avanço e evasão escolar no Brasil. Pesquisa e Planejamento Econômico, Rio de Janeiro, v.32, n.3, dez. 2002.

LEONTIEV, A. N. Desenvolvimento do psiquismo. Trad. R. E. FRIAS. 2. ed. São Paulo: Centauro, 2004.

LEONTIEV, A. N. As necessidades e os motivos da atividade. Tradução de A. M. LONGAREZI e P. L. J. FRANCO. Revisão de E. S. ARAUJO. In: LONGAREZI, A. M.; PUENTES, R. V. Ensino desenvolvimental: antologia. Livro1, v. 4, Uberlândia, MG: EDUFU, 2017.

LONGAREZI, A. M.; PUENTES, R. V. Fundamentos psicológico-didáticos para um ensino na perspectiva histórico-cultural: a unidade dialética obutchéniedesenvolvimento. In: LONGAREZI, A. M.; PUENTES, R. V. (Orgs.). Fundamentos psicológicos e didáticos do Ensino Desenvolvimental. Uberlândia: Edufu, 2017.

LONGAREZI, A. M.; DIAS DE SOUSA, W. D. Unidades possíveis para uma obutchénie dialética e desenvolvedora. Dossiê Didática desenvolvimental: uma abordagem a partir de diferentes concepções histórico-culturais. Linhas Críticas. Vol. 24, 2019, p. 453-474. Disponível em: \&lt; http://periodicos.unb.br/index.php/linhascriticas/article/view/19815/20635 \& gt; (DOI: DOI 10.26512/lc.v24i0.19815)

MAKARENKO, A. Poema pedagógico. Tradução de T. BELINKY. Posfácio de Z. PRESTES. 3. ed. São Paulo: Editora 34, 2012.

MARQUES, M. A reconstrução dos cursos de formação do profissional da educação. Em aberto, Brasília, v. 12, n. 54, 1992. 
MARSIGLIA, A. C. G. et al. A Base Nacional Comum Curricular: um novo episódio de esvaziamento da escola no Brasil. Germinal: Marxismo e Educação em Debate, Salvador, v. 9, n. 1, p. 107-121, 2017.

MARX, K. O Capital: crítica da economia política. Tradução de Reginaldo Sant'Anna. 24. ed. Rio de Janeiro: Civilização Brasileira, 2006. Livro I, v. I.

MELERO, M. L. Aprendiendo a conocer a las personas con síndrome de Down. Málaga: Aljibe, 1999.

MILITÃO, S. C. N.; MILITÃO, A. N.; PERBONI, F. Do PNE/2001 ao novo PNE (2011-2020): o financiamento da educação em análise. In: SEMINÁRIO INTERNACIONAL DE REPRESENTAÇÕES SOCIAIS, SUBJETIVIDADE E EDUCAÇÃO-SIRSSE, Curitiba, 2011. v. 1, p. 8090-8102.

MORAES, S. P. G. de. Avaliação do processo de ensino e aprendizagem em matemática: contribuições da teoria histórico-cultural. 2008. Tese (Doutorado em Educação) - Faculdade de Educação, Universidade de São Paulo, São Paulo, 2008.

MORAES, S. P. G.; MOURA, M. O de. Avaliação do processo de ensino e aprendizagem em matemática: contribuições da teoria históricocultural. Bolema - Boletim de Educação Matemática, Rio Claro, v. 22, n. 33, p. 97-116, 2009.

MORETTI, V. D. Professores de matemática em atividade de ensino: uma perspectiva histórico-cultural para a formação docente. 2007. Tese (Doutorado em Educação) - Faculdade de Educação, Universidade de São Paulo, São Paulo, 2007.

MOURA, M. O. et al. Controle da variação de quantidades: atividades de ensino. [S.I: s.n.], 1996.

MOURA, M. O de. $O$ educador matemático na coletividade de formação: uma experiência com a escola pública. São Paulo: USP, 2000.

MOURA, M. O. de et al. Atividade orientadora de ensino: unidade entre ensino e aprendizagem. Revista Diálogo Educacional, Curitiba, v. 10, n. 29, p. 205-229, 2010.

MOURA, O. de M. et al. Atividade Orientadora de Ensino como unidade entre ensino e aprendizagem. In: MOURA, M. O. de (org.). A atividade pedagógica na teoria histórico-cultural. Campinas, SP: Autores Associados, 2016.

MOURA, M. O. de et al. Atividades para o ensino de Matemática nos anos iniciais da Educação Básica. São Paulo: Câmara Brasileira de Livros, 2019.

MOURA, M. O de.; ARAUJO, E. S. A atividade orientadora de ensino como mediação. In: BEATÓN, G. A. et al. (org.). Temas escolhidos na psicologia histórico-cultural interfaces Brasil-Cuba. Maringá: Eduem, 2018.

MOURA, M. O. de; SFORNI, M. S. de F.; LOPES, A. R. L. V. Objetivação do ensino e o desenvolvimento do modo geral de aprendizagem da atividade 
pedagógica. In: MOURA, M. O. de (org.). Educação escolar e pesquisa na teoria histórico-cultural. São Paulo: Loyola, 2017. p. 71-100.

MUNHOZ, A. P. G.; MOURA, M. O. Ações formadoras em atividade de formação contínua com professores que ensinam matemática nos anos iniciais da escolarização: uma iniciativa na perspectiva da teoria histórico-cultural. Revista Paranaense de Educação Matemática, Campo Mourão, 2019.

NARDI, E. L.; SCHNEIDER, M. P. Políticas de accountability na educação básica: repercussões em municípios catarinenses. In: REUNIÃO ANUAL DA ANPED, 35., 2012, Porto de Galinhas. Anais... Rio de Janeiro: ANPEd, 2012. p. $1-17$.

NASCIMENTO, C. P. Por que é tão indesejável admitir radicalmente a excepcionalidade na realização da atividade pedagógica em meio à pandemia?

Disponível

em:

https://universidadeaesquerda.com.br/excepcionalidade-das-atividades-

pedagogicas-na-pandemia. Acesso em: 04 dez. 2020.

PALUDO, C. Educação popular como resistência e emancipação humana. Cadernos CEDES, Campinas, SP, v. 35, n. 96, p. 219-23, maio/ago. 2015.

PETROVSKI, A. V. Personalidad, actividad y colectividad. Buenos Aires: Editorial Cartago, 1984.

PIOTTO, D. C. Bases vigotskianas da Atividade Orientadora de Ensino. Obutchénie: Revista de Didática e Psicologia Pedagógica, Uberlândia, p. 334-354, 2020.

PIRES, V. L. Dialogismo e alteridade ou a teoria da enunciação em Bakhtin. Organon, Porto Alegre, v. 16, n. 32-33, 2002.

PRESTES, Z. R. Quando não é a mesma coisa: análise de traduções de Lev Semionovitch Vigotski no Brasil: repercussões no campo educacional. Tese (Doutorado em Educação) - Faculdade de Educação, Universidade de Brasília, Brasília, 2010.

PRESTES, Z. R. A sociologia da infância e a teoria histórico-cultural: algumas considerações. Revista de Educação Pública, Cuiabá, v. 22, n. 49/1, p. 295304, 2013.

RAVITCH, D. Nota mais alta não é educação melhor. O Estado de S. Paulo, 02 de ago. 2010. Disponível em: https://ciencia.estadao.com.br/noticias/geral,nota-mais-alta-nao-e-educacaomelhor-imp-,589143. Acesso em: 27 maio 2018.

RIGON, A. J.; ASBAR, F. S. F.; MORETTI, V. D. Sobre o processo de humanização. In: MOURA, M. O. de (org.). A atividade pedagógica na teoria histórico-cultural. Campinas, SP: Autores Associados, 2016. 
ROSA, J. E. Proposições de Davydov para o ensino de matemática no primeiro ano escolar: inter-relações dos sistemas de significações numéricas. Tese (Doutorado em Educação) - Universidade Federal do Paraná, Curitiba, 2012.

ROSA, J. E.; MORAES, S. P. G. de; CEDRO, W. L. As particularidades do pensamento empírico e do pensamento teórico na organização do ensino. In: MOURA, M. O. de (org.). A atividade pedagógica na teoria históricocultural. Campinas, SP: Autores Associados, 2016.

RUIZ, M. J. F. Trabalho coletivo na escola pública: contribuições pedagógicas de Anton Semionovitch Makarenko. Schème: Revista Eletrônica de Psicologia e Epistemologia Genéticas, Marília, v. 9, n. 1-2, p. 223-223, 2008.

SERRA, C. B. Relatório parcial apresentado à Fundação de Amparo à Pesquisa do Estado de São Paulo (Fapesp). Setembro 2018 - agosto 2019. In: ARAUJO, E. S. Gênese e desenvolvimento da organização do ensino de matemática em um município paulista. Ribeirão Preto, SP, Brasil: Faculdade de Filosofia, Ciências e Letras de Ribeirão Preto (FFCLRP), Universidade de São Paulo. Processo 2016/ 07750-3.

SOUSA, M. do C. de. O ensino de álgebra numa perspectiva lógico-histórica: um estudo das elaborações correlatas de professores do ensino fundamental. 2004. Tese (Doutorado em Educação) - Universidade Estadual de Campinas SP, 2004.

SOUSA, S. Z. Concepções de qualidade da educação básica forjadas por meio de avaliações em larga escala. Avaliação: Revista da Avaliação da Educação Superior, Campinas, v. 19, n. 2, 2014.

TOMÁS, C. Infância como um campo de estudo multi e interdisciplinar: Algumas reflexões. Revista Psicologia e Educação, Covilhã, v. 1, p. 131-146, 2002.

VIGOTSKI, L. S. A construção do pensamento e da linguagem. Trad. P. BEZERRA. São Paulo: Martins Fontes, 2001.

VIGOTSKI, L. S. Psicologia pedagógica. Trad. Claudia Schilling. Ed. Comentada. Porto Alegre: Artmed, 2003.

VIGOTSKI, L. S. A formação social da mente: o desenvolvimento dos processos psicológicos superiores. São Paulo: Martins Fontes, 2007.

VIGOTSKI, L. S. Psicologia pedagógica. Tradução do russo e introdução de P. BEZERRA. 3. ed. São Paulo: Editora WMF Martins Fontes, 2010.

VIGOTSKI, L. S. Imaginação e criatividade na infância. Tradução de J. P. FRÓIS. Revisão técnica e da tradução Solange Affeche. São Paulo: Editora WMF Martins Fontes, 2014. (Coleção Textos de Psicologia).

VIGOTSKI, L. S. O problema do ambiente na Pedologia. Tradução de A. B. MATTOS. Revisão de V. GARCEZ e R. V. PUENTES. In: LOGAREZI, A. M.; 
PUENTES, R. V. Ensino desenvolvimental: antologia. Livro1, v. 4, Uberlândia, MG: EDUFU, 2017.

VIGOTSKI, L. S. Sete aulas de L. S. Vigotski sobre os fundamentos da pedologia. Tradução e organização de Z. PRESTES e E. TUNES. Rio de Janeiro: E-Pepers, 2018. 


\section{ANEXOS}

\section{ANEXO 1 - MATERIAL: Avaliações Somativas - (ano 2016)}

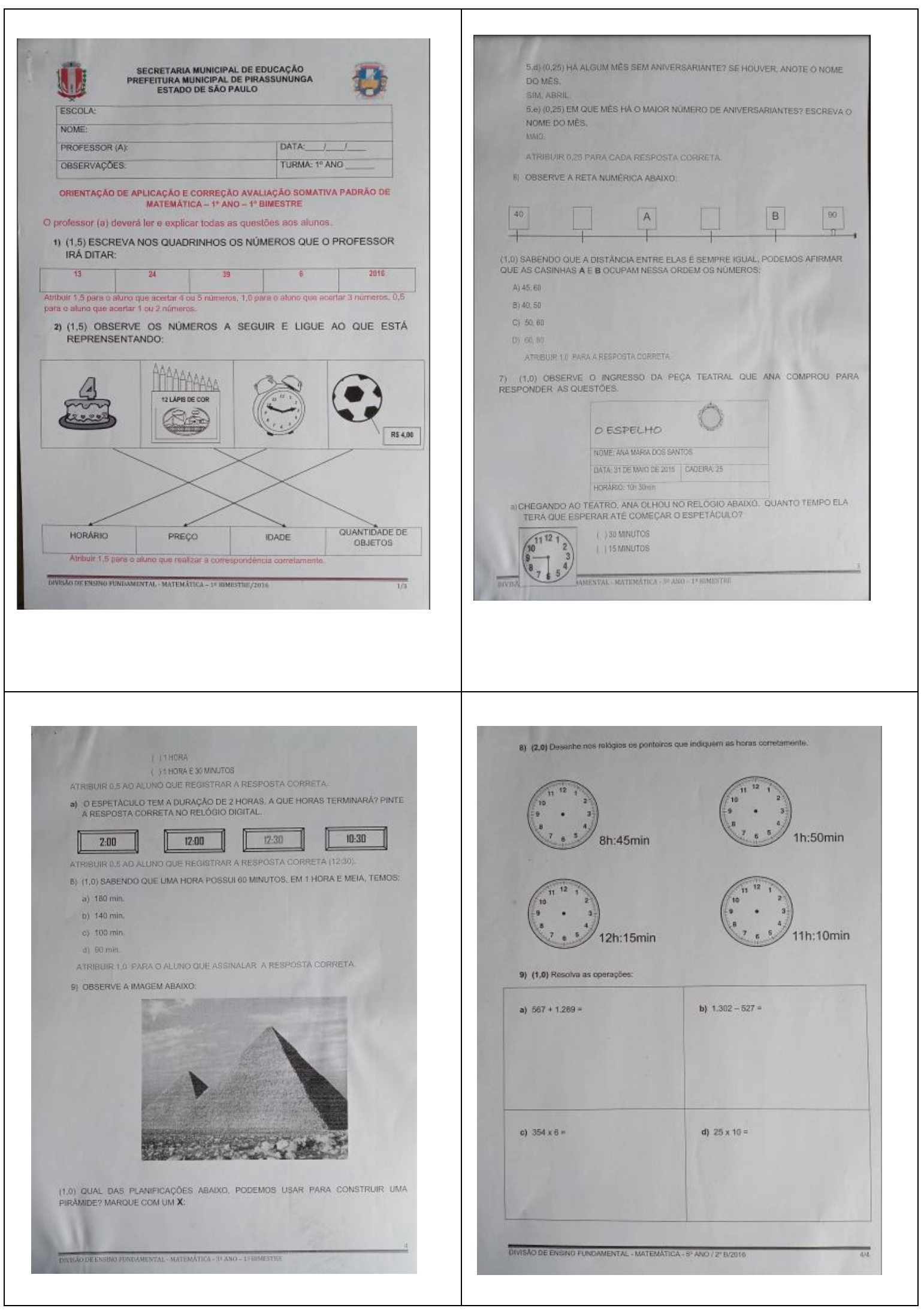




\section{ANEXO 2 - MATERIAL: Modelo de ficha de acompanhamento das aprendizagens e avanços (período entre 2017 e 2019)}

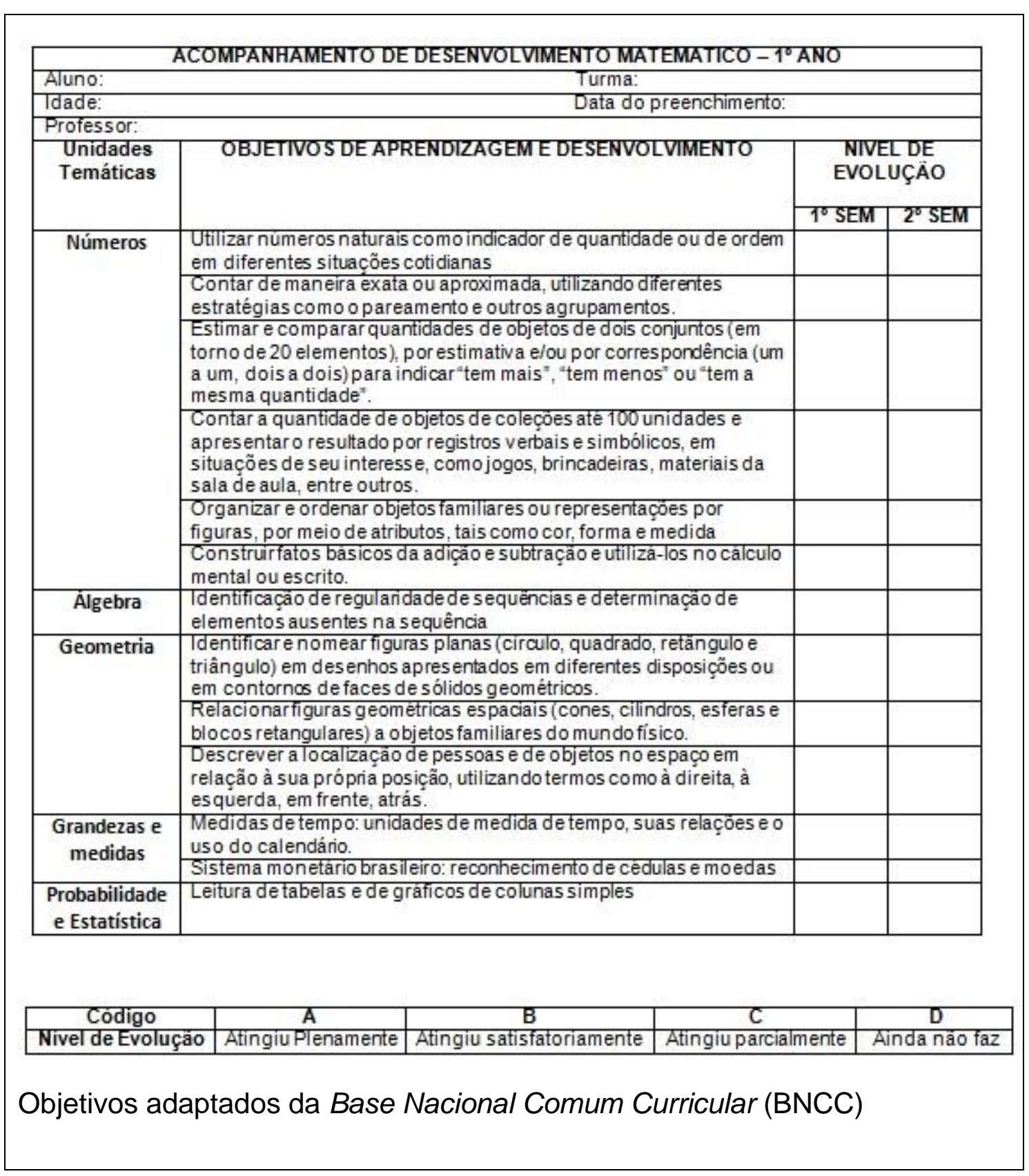


ANEXO 3 - MATERIAL: Modelo de roteiro utilizado como guias para diagnóstico dos conhecimentos matemáticos (período entre 2017 e 2019)

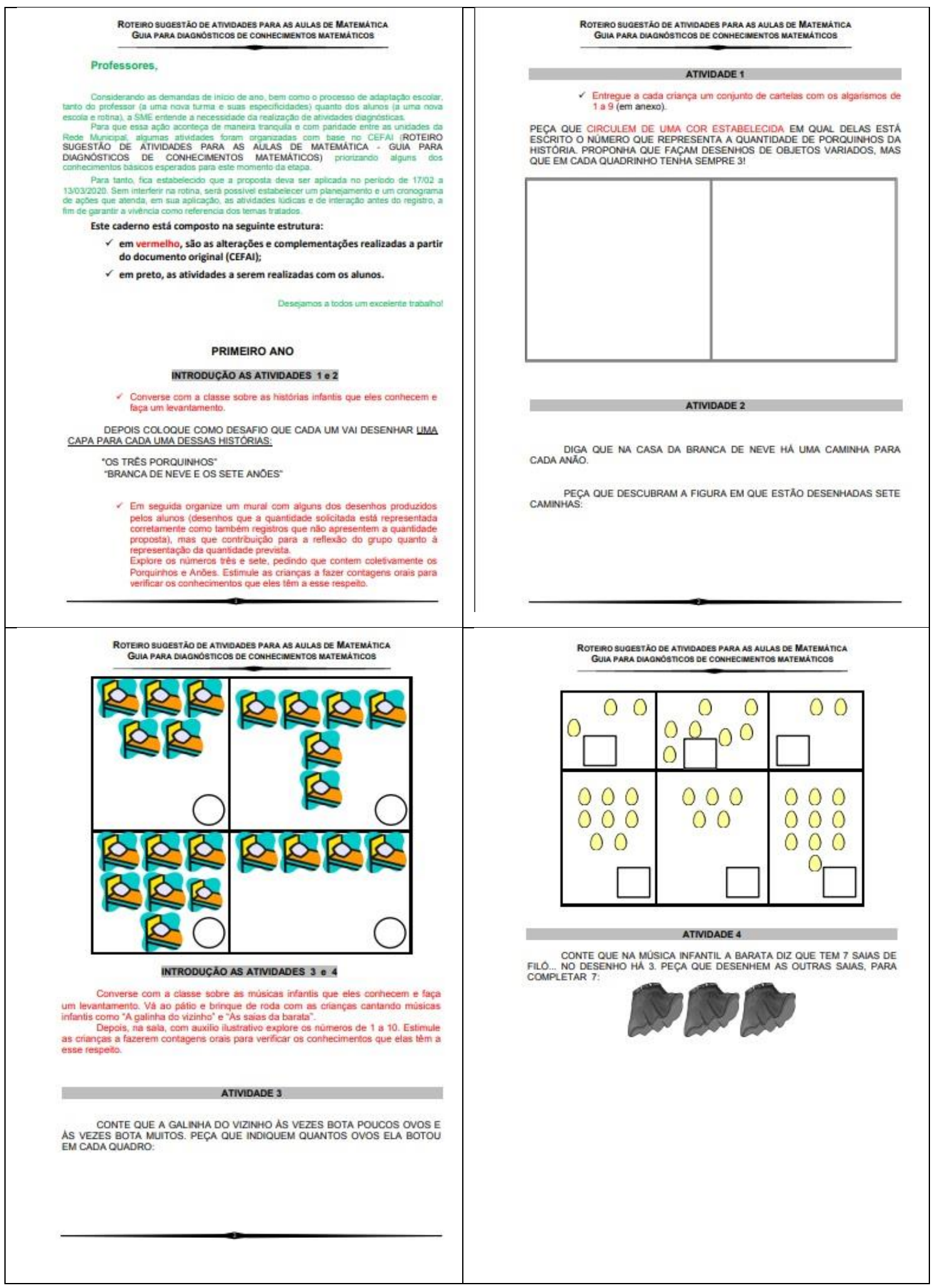




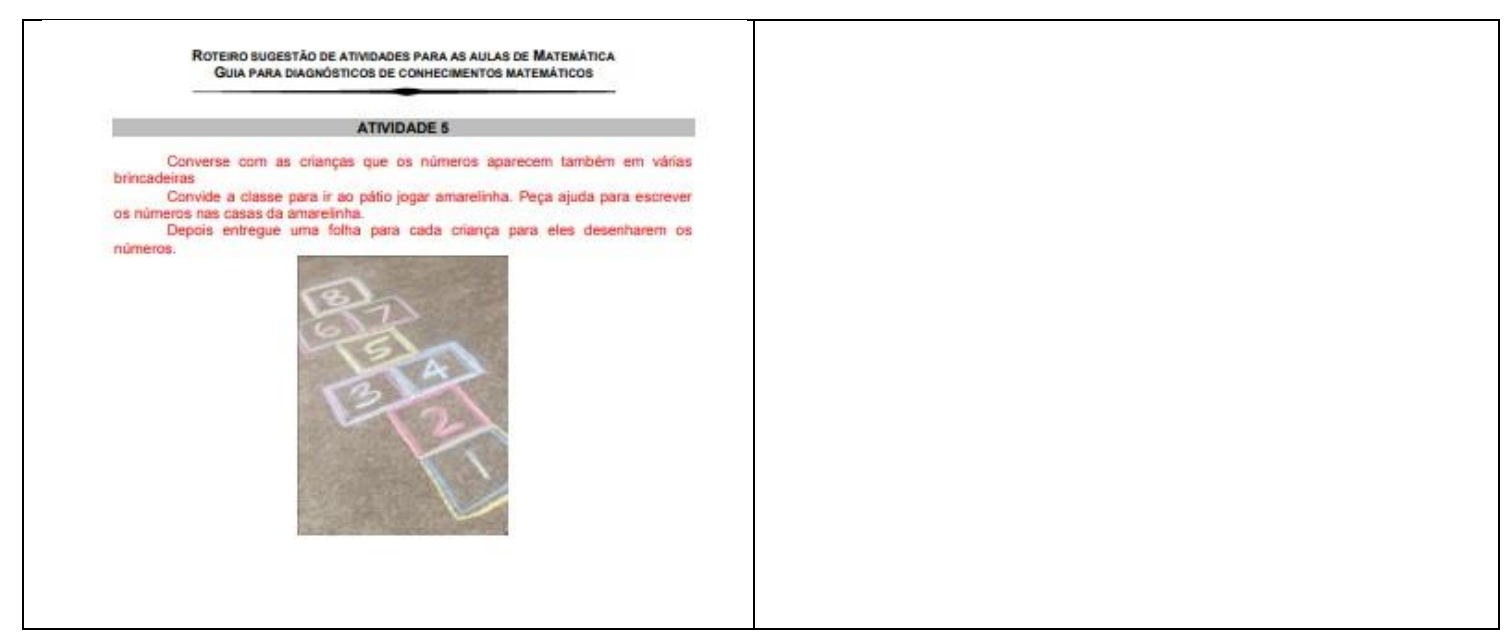


ANEXO 3 - MATERIAL: Modelo de entrevista enviada às famílias (ano 2021)

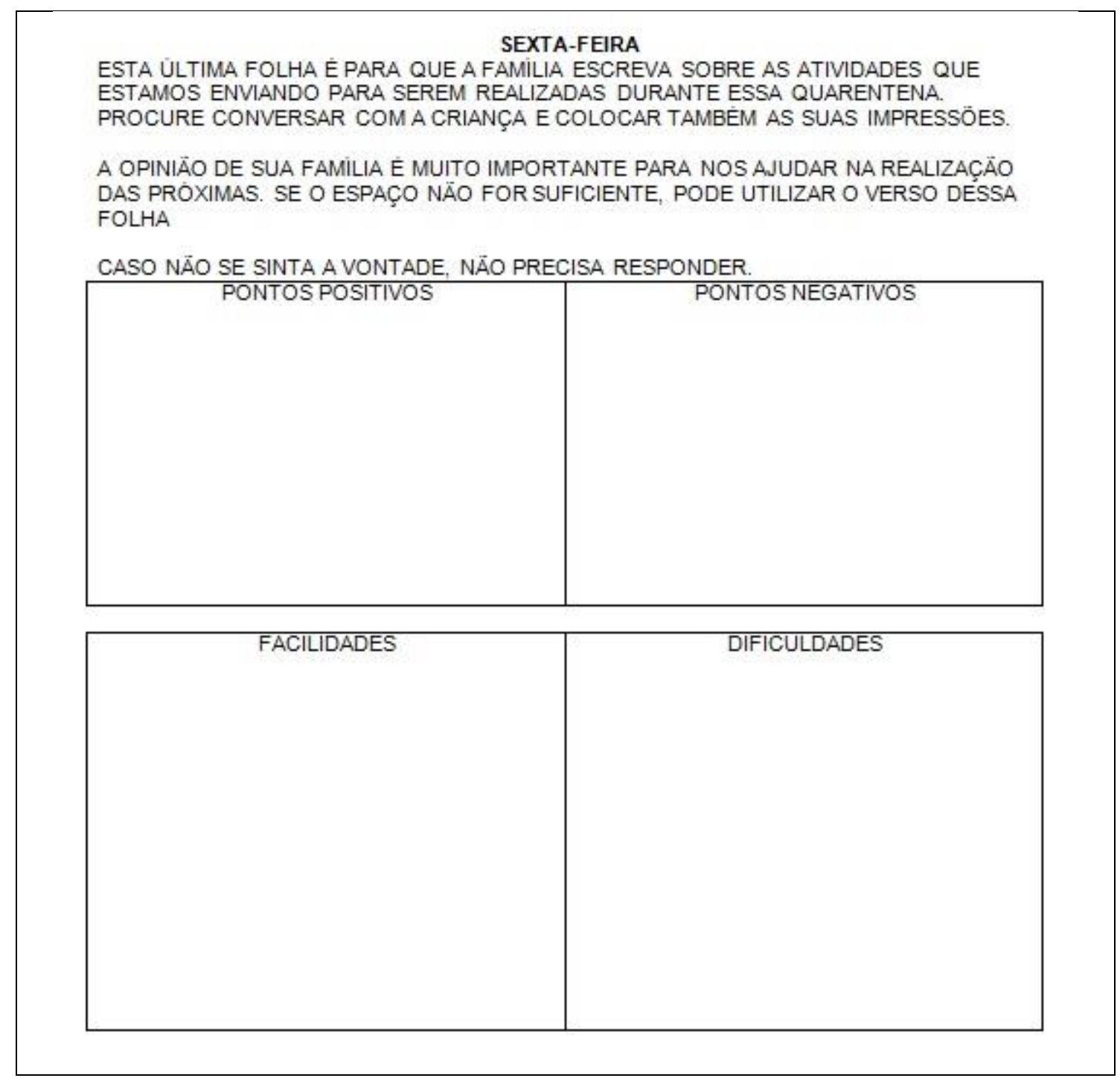




\section{ANEXO 5 - Sequência Didática para o Ensino das Horas}

\section{$4^{\circ}$ ANOS}

GRUPO DE P.C. que elaborou as atividades:

Sugere-se que o professor traga para a classe um relógio grande, construído de papelão, com ponteiros - minutos e segundos, para que os alunos possam manuseálo na realização das atividades.

Também é recomendado ter um relógio analógico (de ponteiros) na sala de aula, para ser explorado com os alunos.

SUGESTÕES DE SITUAÇÕES DIDÁTICAS

Frequência: 1 vez por semana (9 atividades)

- $1^{\mathrm{a}}$ atividade (15 minutos)

Objetivo: Reconhecer unidades usuais de tempo.

Encaminhamentos:

Discutir com os alunos sobre o que sabem acerca das medidas do tempo - anotar as respostas dos alunos. (Professor: trazer o cartaz pronto, com os dados das horas, minutos e segundos, para deixar afixado na sala):

Questões:

a) Quantas horas tem um dia?

b) Quantos minutos tem uma hora?

c) Quantos segundos tem um minuto?

Cartaz

Medidas de tempo

1 dia $=24$ horas

1 hora $=60$ minutos

1 minuto $=60$ segundos

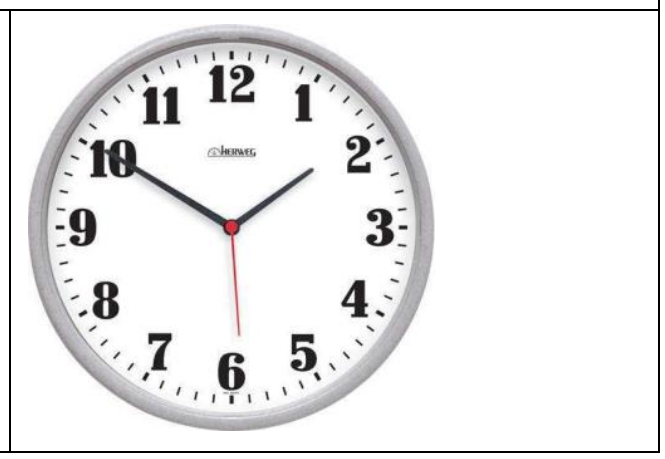

- $\quad 2^{\mathrm{a}}$ atividade (15 minutos)

Objetivo: Reconhecer unidades usuais de tempo.

Se uma hora tem 60 minutos, quantos minutos tem meia hora?

Socializar utilizando os ponteiros do relógio. 
- $3^{\mathrm{a}}$ atividade (15 minutos)

Objetivo: utilizar medidas de tempo em realizações de conversão simples.

(Professor: levar um relógio, construído em papelão, com ponteiros para a resolução da situação problema)

Problema:

Joana saiu de casa às 6 horas para chegar à escola as 7horas e 10 minutos. Quantos minutos ela gastou para chegar à escola?

Encaminhamento:

Para a socialização das respostas apresentadas o professor utilizará o relógio de papelão para demonstrar a passagem do tempo movimentando os ponteiros.

- $4^{\mathrm{a}}$ atividade (retomar a atividade anterior) (15 minutos)

Objetivo: utilizar medidas de tempo em realizações de conversão simples. Utilizar unidades de tempo em situações problema.

Problema:

Se Joana gastou 70 minutos para chegar à escola, quantas horas e minutos esse tempo representa?

- $5^{\mathrm{a}}$ atividade (15 minutos)

Objetivo: utilizar medidas de tempo em realizações de conversão simples.

Professor: colocar a tabela na lousa e escolher 3 alunos para dizer o tempo que gastam para chegar à escola:

\begin{tabular}{|l|l|l|}
\hline & Saiu de casa & Chegou à escola \\
\hline Aluno 1 & & \\
\hline Aluno 2 & & \\
\hline Aluno 3 & & \\
\hline
\end{tabular}

Quem demorou mais tempo para chegar à escola? (Professor: registrar as respostas dos alunos para retomá-las na atividade 6)

- $6^{\mathrm{a}}$ atividade (15 minutos)

Objetivo: Análise da tabela construída anteriormente com as seguintes questões:

a) Quem demorou mais tempo para chegar à escola?

b) Quem demorou menos tempo?

c) Qual a diferença de tempo gasto entre os dois?

Chamar um aluno para representar no relógio de papelão o tempo que o aluno levou para chegar à escola.

- $7^{\mathrm{a}}$ atividade (15 minutos)

Objetivo: Reconhecer unidades usuais de tempo.

Luana estuda 1 hora por dia, quantas horas estudará em uma semana? 
- $8^{\mathrm{a}}$ atividade (15 minutos)

Objetivo: Ler informações de tempo em diferentes registros.

Ana realiza diversas atividades durante a semana. Observe a tabela abaixo e responda:

\begin{tabular}{|l|l|}
\hline Atividade & Tempo gasto \\
\hline Estudar & $1 \mathrm{~h} 30 \mathrm{~min}$ \\
\hline Almoçar & $20 \mathrm{~min}$ \\
\hline Caminhar & $2 \mathrm{~h} 15 \mathrm{~min}$ \\
\hline Passear & $3 \mathrm{~h}$ \\
\hline Tomar banho & 15 min \\
\hline
\end{tabular}

Em qual atividade Ana gasta mais tempo?

Transformando em minutos, quanto tempo Ana gasta passeando?

- $\quad 9^{a}$ atividade (15 minutos)

Objetivo: Reconhecer unidades usuais de tempo.

Se 1 hora tem 60 minutos, quantos minutos têm 8 horas? 